RAISSA CAROLINE FARIA FREITAS

O Processo de Adoção do BIM em Empresas Públicas e em Construtoras de Infraestrutura 
RAISSA CAROLINE FARIA FREITAS

O Processo de Adoção do BIM em Empresas Públicas

e em Construtoras de Infraestrutura

Dissertação apresentada à Escola

Politécnica da Universidade de São Paulo

para obtenção do título de Mestre em

Ciências.

São Paulo

2020 
RAISSA CAROLINE FARIA FREITAS

\title{
O Processo de Adoção do BIM em Empresas Públicas e em Construtoras de Infraestrutura
}

\author{
Versão Corrigida
}

Dissertação apresentada à Escola Politécnica da Universidade de São Paulo para obtenção do título de Mestre em Ciências.

Área de Concentração: Engenharia de Construção Civil e Urbana

Orientador: Prof. Dr. Silvio Burrattino Melhado 
Autorizo a reprodução e divulgação total ou parcial deste trabalho, por qualquer meio convencional ou eletrônico, para fins de estudo e pesquisa, desde que citada a fonte.

Este exemplar foi revisado e corrigido em relação à versão original, sob responsabilidade única do autor e com a anuência de seu orientador.

São Paulo, de de

Assinatura do autor:

Assinatura do orientador:

\section{Catalogação-na-publicação}

\section{FREITAS, RAISSA}

O Processo de Adoção do BIM em Empresas Públicas e em Construtoras de Infraestrutura / R. FREITAS -- versão corr. -- São Paulo, 2020.

$226 \mathrm{p}$.

Dissertação (Mestrado) - Escola Politécnica da Universidade de São Paulo. Departamento de Engenharia de Construção Civil.

1.BIM 2.Adoção do BIM 3.Inovação 4.Gestão de Projetos 5.Modelagem da Informação I.Universidade de São Paulo. Escola Politécnica. Departamento de Engenharia de Construção Civil II.t. 
FREITAS, R. C. F. O Processo de Adoção do BIM em Empresas Públicas e em Construtoras de Infraestrutura. São Paulo. 2020. 200 p. (Mestrado) Escola Politécnica, Universidade de São Paulo, São Paulo, 2020. 


\section{AGRADECIMENTOS}

Ao meu orientador Prof. Dr. Silvio Burrattino Melhado por ter acreditado em mim e no meu potencial como pesquisadora, por ter me aceito neste programa, por toda a motivação durante o desenvolvimento do trabalho, pelas oportunidades que me propiciou como mestranda e por todo o auxílio no desenvolvimento deste trabalho.

À todas as empresas que aceitaram participar dos estudos de caso e os profissionais que se dispuseram a participar das entrevistas e compartilhar suas experiências e os documentos relevantes.

À minha família e amigos por todo o suporte durante o desenvolvimento deste estudo, pela paciência e pela compreensão da minha ausência.

À todas as pessoas especiais que cruzaram o meu caminho durante essa jornada e me deram suporte de alguma maneira.

Muito obrigada! 


\section{RESUMO}

O processo de adoção do Building Information Modeling (BIM) é desafiador para qualquer empresa, uma vez que ele representa uma sucessão de mudanças em todas as esferas da organização, resultando em modificações nos processos de trabalho, na gestão das informações, nas formas de comunicação, na maneira de fazer e no modo de compreender os projetos. Assim como qualquer outra mudança massiva de processos, a adoção do BIM suscita preocupações e gera incertezas nos profissionais, por esse motivo é fundamental que eles entendam o significado dessa implantação e como isso impactará seu trabalho. A implantação desse método é trabalhosa e possui diversos caminhos relatados na revisão bibliográfica, portanto depende integralmente dos objetivos, da estratégia e da vontade da empresa em passar por todo esse processo de transformação. Além disso, a trajetória do processo de adoção do BIM é longa e depende da eficiência das etapas de planejamento, estruturação, desenvolvimento e implementação. Após o sucesso dessas etapas, o processo de amadurecimento é contínuo. Este trabalho aborda as diferentes maneiras de se conduzir esse processo que estão registradas na bibliografia e posteriormente relata como está sendo realizado na prática em quatro empresas de São Paulo. As organizações acompanhadas durante o estudo de caso são do setor de infraestrutura e estão seguindo caminhos distintos para a implantação do método no seu dia a dia. As experiências descritas servirão para realizar uma análise cruzada entre elas e as melhores práticas descritas na bibliografia, sendo possível a identificação das fases fundamentais para o sucesso do processo de adoção, as questões chaves que deverão ser levadas em conta em cada uma dessas etapas, os desafios que podem ser encontrados e como superálos.

Palavras-Chave: Building Information Modeling. Gestão de Projetos. Modelagem da Informação. Inovação. Adoção do BIM. 


\begin{abstract}
The Building Information Modeling - BIM adoption process is challenging, since it represents a succession of changes in all the companies' areas, resulting in modifications in the work processes, in the information management, in the means of communication and in the projects' design and understanding. As well as any other significant process change, the BIM deployment raises concerns and causes uncertainties among the professionals involved. Therefore, it is substantial that these professionals comprehend the meaning of this employment and how it might interfere in their work. This methodology rollout is laborious and there are many approaches to this end, hence it relies on the company's objectives, strategies and willingness to go through this transformation process. Moreover, the BIM adoption process is quite long and it depends on the efficiency of a set of steps such as planning, structuring, development, implementation and continuous maturing. This thesis approaches the different ways of conducting this process that are mentioned in the bibliographies. Afterwards, it reports the distinct experiences of five large infrastructure companies of São Paulo city during its BIM adoption process. In addition, it will be developed a cross analysis between these descriptions and the best practices from the bibliographical references, identifying the deployment phases for the BIM adoption process, the key aspects to each step, the frequent faced challenges and how to overcome them. Accordingly, the specific goal of this thesis related to propose a practical procedure to BIM adoption in infrastructure companies will be achievable. This objective is of the utmost importance to this theme nationally due to the shortcoming of bibliographical references in this context and the struggle faced by the organizations during this adoption process.
\end{abstract}

Keywords: Building Information Modeling. Project Management. Information Modeling. Innovation. BIM Adoption. 


\section{LISTA DE FIGURAS}

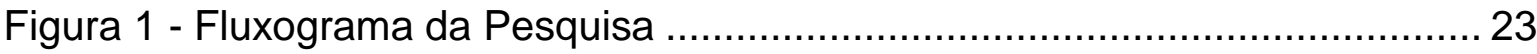

Figura 2 - O fluxo da informação com o uso do BIM ......................................... 30

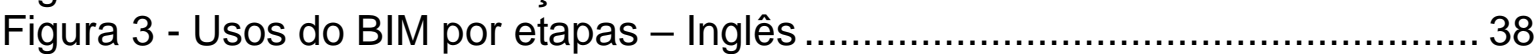

Figura 4 - Usos do BIM por etapas - traduzido................................................ 39

Figura 5 - Detecção de automática de interferências em construções complexas 42

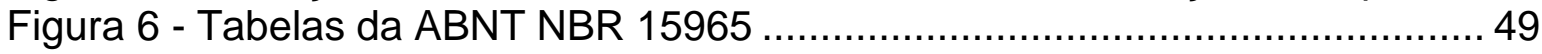

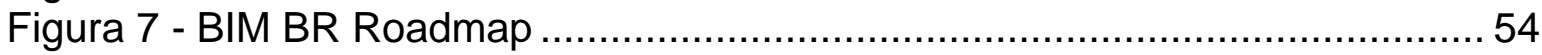

Figura 8 - Principais etapas para um projeto de adoção do BIM ........................ 61

Figura 9 - Ciclo de vida de um empreendimento.......................................... 62

Figura 10 - Tabela de seleção dos usos BIM adaptada de CIC (2010) ................64 64

Figura 11 - Planilha de troca de informações adaptada de CIC (2010).................66

Figura 12 - Grupos de processos de gerenciamento de projetos .........................69 69

Figura 13 - Os grupos de processos interagem em uma fase ou em um projeto .. 70

Figura 14 - Grupo de processos de gerenciamento de projetos ....................... 71

Figura 15 - Interações nos processos de gerenciamento de projetos .................. 73

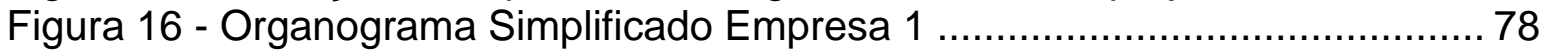

Figura 17 - Linha do tempo da implantação do BIM na Empresa 1 ...................... 79

Figura 18 - Detecção de interferência ........................................................... 80

Figura 19 - Projeto preliminar da estação ...................................................... 81

Figura 20 - Exemplo de análise de folha realizada digitalmente ........................ 82

Figura 21 - Modelo BIM vista 3D ............................................................... 83

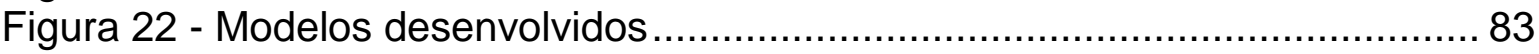

Figura 23 - Quantidade de comentários por natureza .................................. 87

Figura 24 - Exemplo de análise utilizando o padrão BCF ............................... 89

Figura 25 - Primeiro projeto básico que desenvolveram ................................. 90

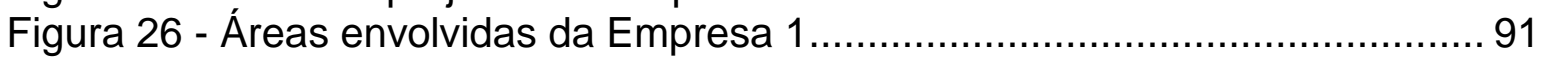

Figura 27 - Estrutura Analítica do Projeto ......................................................... 99

Figura 28 - Organograma Simplificado da Empresa 2 .................................... 102

Figura 29 - Timeline da implantação do BIM na Empresa................................... 103

Figura 30 - Nuvem de pontos do laser scanning ............................................ 105

Figura 31 - Identificação de interferência pelo Navisworks ............................ 107

Figura 32 - Situação atual x modelo - Bilheteria ......................................... 108

Figura 33 - Fases de modelagem....................................................... 109

Figura 34 - Situação anterior x modelo - Plataforma ................................... 110

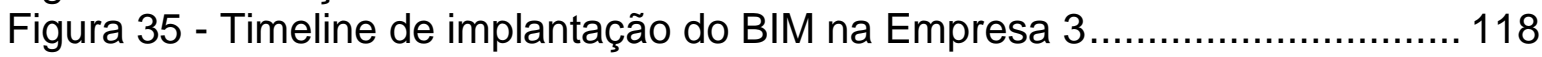

Figura 36 - Fluxo de Modelagem......................................................... 120

Figura 37 - Esquema para desenvolver o Modelo 4D .................................. 122

Figura 38 - Timeline da implantação do BIM na obra piloto .............................. 123

Figura 39 - Obra piloto da Empresa 3 concluída .............................................. 124

Figura 40 - Obra piloto da Empresa 3 concluída ............................................. 124

Figura 41 - Obra piloto da Empresa 3 concluída ............................................ 125

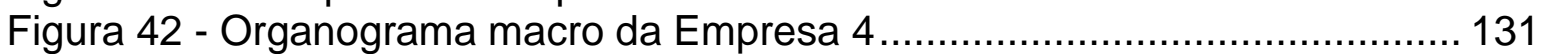

Figura 43 - Linha do Tempo 2015-2018 .................................................. 133

Figura 44 - Cronograma do Plano Trienal do BIM 2018, 2019 e 2020 ................ 134

Figura 45 - Cronograma BIM 2018 .................................................... 136

Figura 46 - Representação do ciclo de vida de um empreendimento típico da

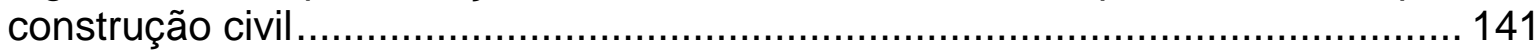

Figura 47 - A Implantação do BIM e a Gestão De Projetos............................... 185 


\section{LISTA DE GRÁFICOS}

Gráfico 1 - Profissionais atuantes na Construção Civil total e com carteira assinada

Gráfico 2 - Valor agregado e esforço do processo BIM versus o processo tradicional

Gráfico 3 - Capacidade do BIM em influenciar os custos até a entrega do

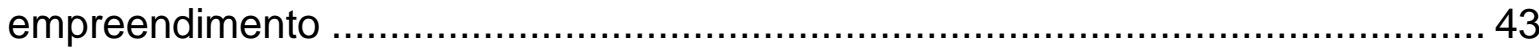

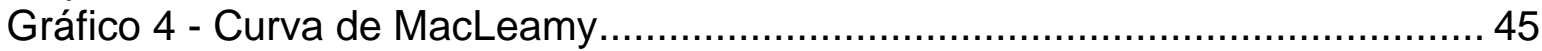

Gráfico 5 - Quantidade de comentários por revisão de projeto ........................... 84

Gráfico 6 - Tempo de análise por disciplina de projeto em dias ............................. 85

Gráfico 7 - Quantidade de comentários por natureza....................................... 86

Gráfico 8 - Respostas da Pergunta 1 ......................................................... 93

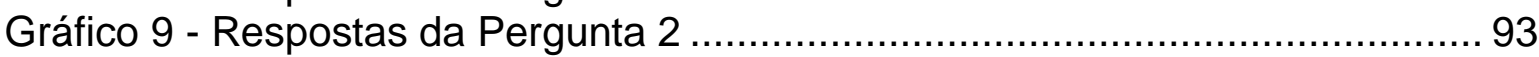

Gráfico 10 - Respostas da Pergunta 3 .......................................................... 94

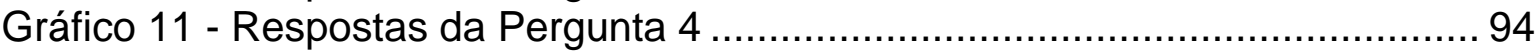

Gráfico 12 - Respostas da Pergunta 4.1 .................................................... 95

Gráfico 13 - Respostas da Pergunta $4.2 \ldots \ldots \ldots \ldots \ldots \ldots \ldots \ldots \ldots \ldots \ldots \ldots \ldots \ldots \ldots \ldots \ldots \ldots \ldots \ldots . . .95$

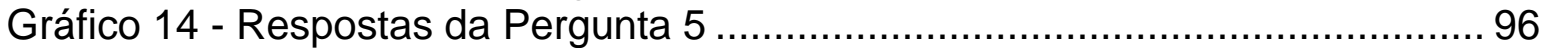




\section{LISTA DE QUADROS}

Quadro 1 - Desafios para a adoção e o uso do BIM 74

Quadro 2 - Comparação do processo de projeto convencionalmente utilizado na

Empresa 2 com o processo de projeto BIM

Quadro 3 - Comparação da adoção do BIM entre as empresas...........................157

Quadro 4 - Desafios para a adoção e o uso do BIM..........................................168

Quadro 5 - Comparação entre os dois primeiros projetos-pilotos. 


\section{LISTA DE ABREVIATURAS E SIGLAS}

ABNT/CEE-134 Comissão de Estudo Especial de Modelagem de Informação da Construção da Associação Brasileira de Normas Técnicas

AEC Arquitetura, Engenharia e Construção

BEP BIM Execution Plan

BIM Building Information Modeling

BIP BIM Implementation Plan

CAD Computer-Aided Design, Desenho Assistido por Computador

$\mathrm{CBIC}$

Câmara Brasileira da Indústria da Construção

CE-BIM

Comitê Estratégico de Implementação do Building Information Modeling

CRC

Cooperative Research Centre for Construction Innovation

DNIT

Departamento Nacional de Infraestrutura de Transportes

DPPG

Diretoria de Pesquisa e Pós-Graduação

ENTAC

Encontro Nacional de Tecnologia do Ambiente Construído

FDE Fundação para Desenvolvimento da Educação

FIESP

Federação das Indústrias do Estado de São Paulo

FGV

Fundação Getúlio Vargas

GAT-BIM

Grupo de Apoio Técnico BIM

GT-BIM

Grupo de Trabalho BIM

MCT

Ministério da Ciência e Tecnologia

MCTIC

Ministério da Ciência, Tecnologia, Inovações e Comunicações

MDIC Ministério da Indústria, Comércio Exterior e Serviços

MPOG

Ministério do Planejamento, Desenvolvimento e Gestão

NBR

Norma Brasileira

PMI

Project Management Institute

PIB

Produto Interno Bruto

RICS

Royal Institution of Chartered Surveyors

SINAPI

Sistema Nacional de Pesquisa de Custos e Índices

SINDUSCON

Sindicato da Indústria da Construção Civil 


\section{SUMÁRIO}

1 INTRODUÇÃO

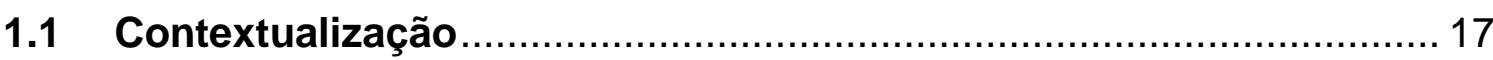

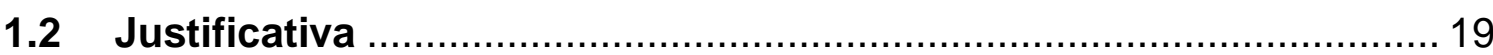

1.3 Objetivos

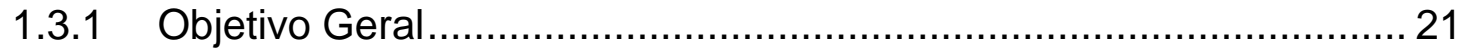

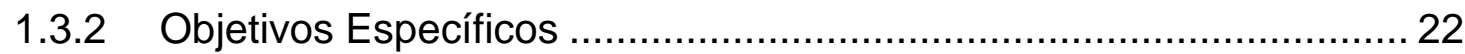

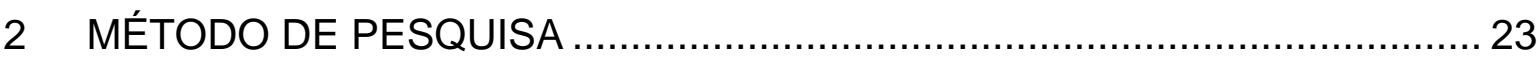

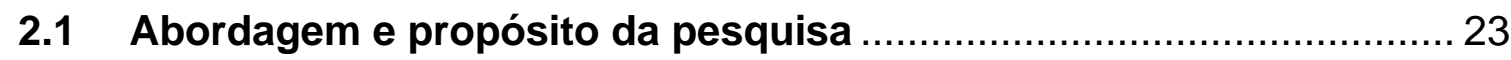

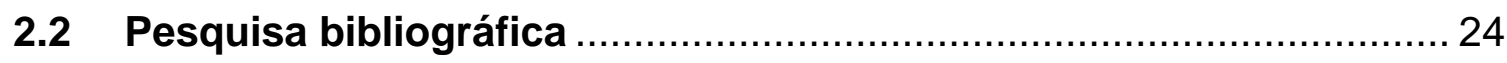

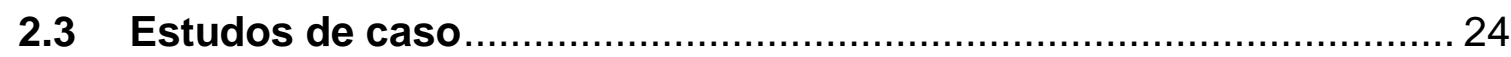

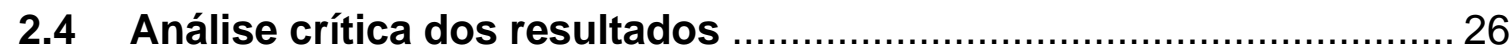

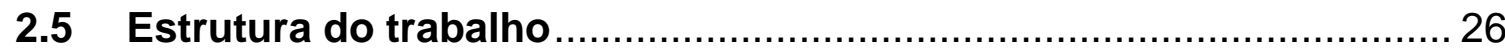

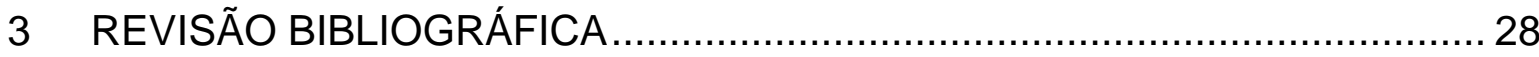

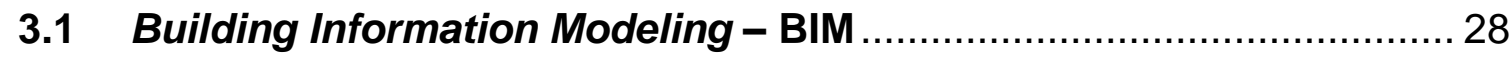

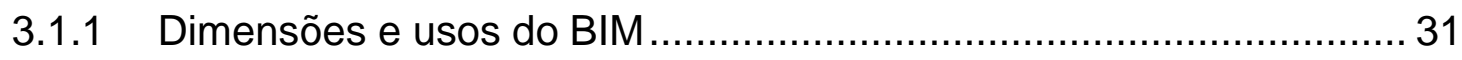

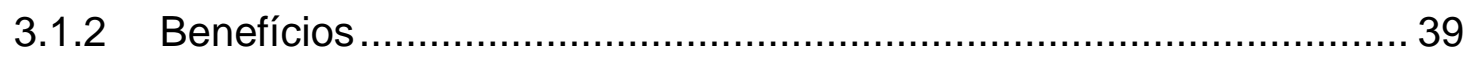

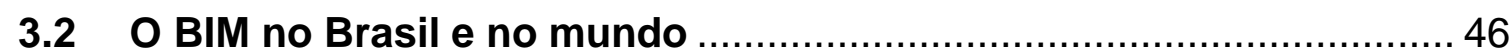

3.3 A Implantação de Inovações e a Rejeição à Mudança .........................54

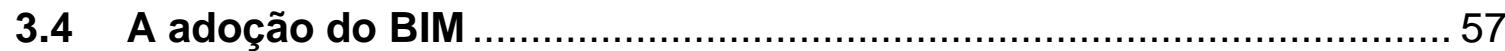

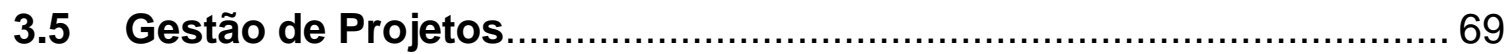

3.6 Desafios de implantação e uso do BIM ………….............................. 74

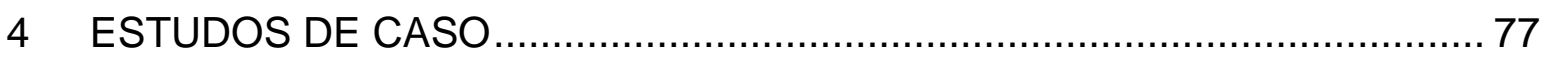

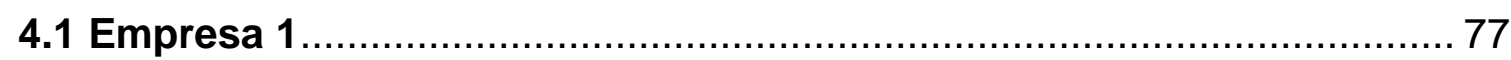

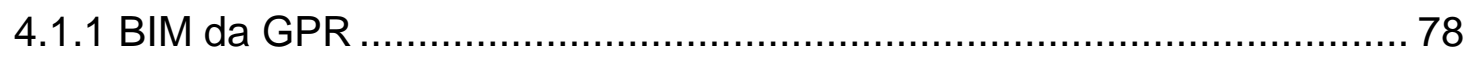

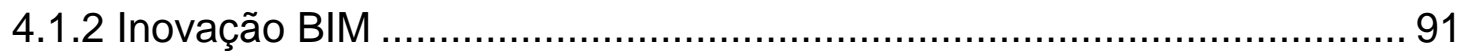

4.1 Empresa 2

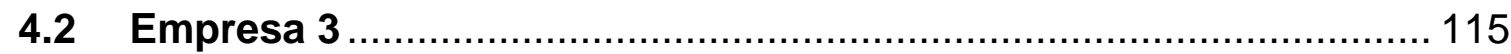

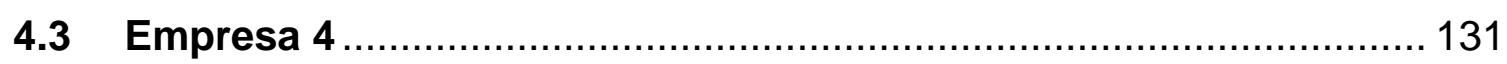

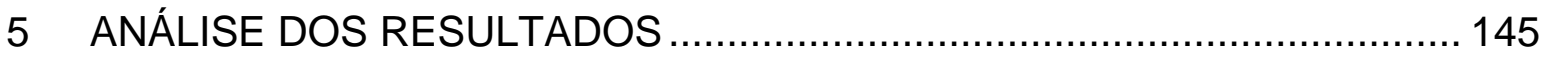

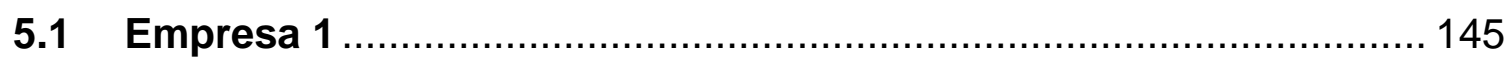

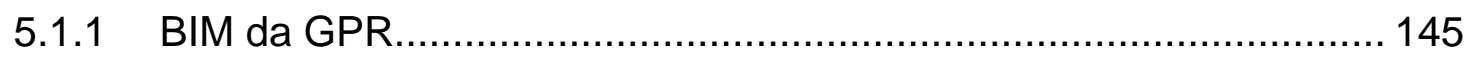

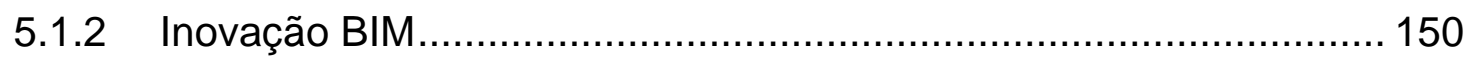

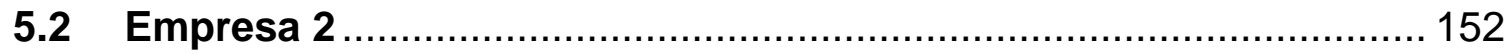

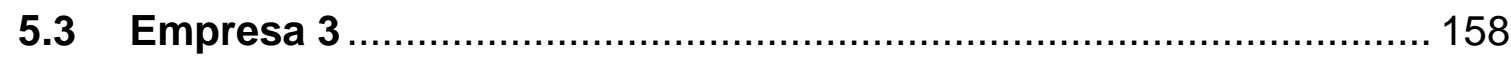


5.4 Empresa 4

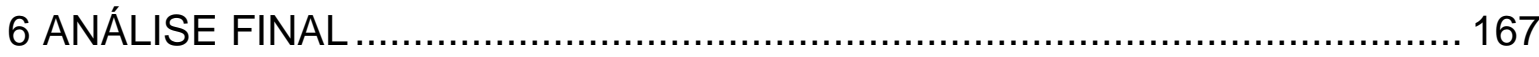

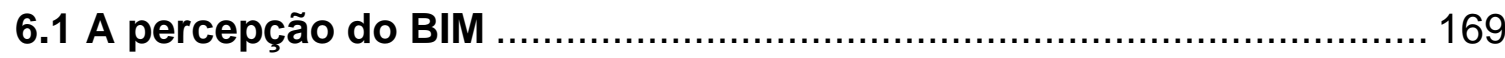

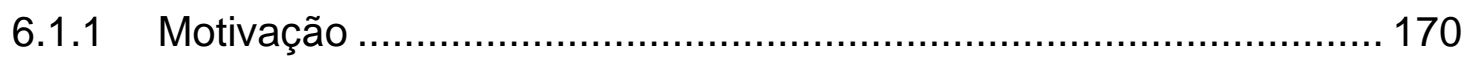

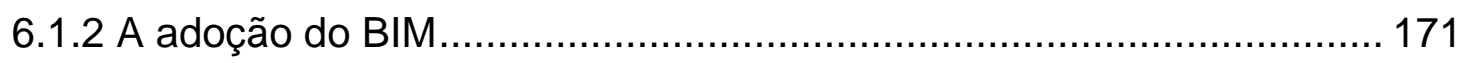

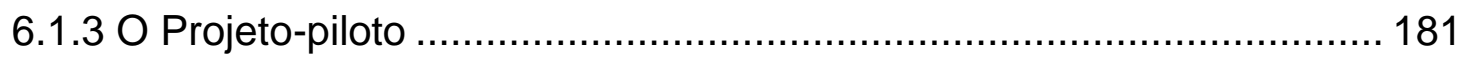

6.1.4 As pessoas e a rejeição à mudança ................................................. 183

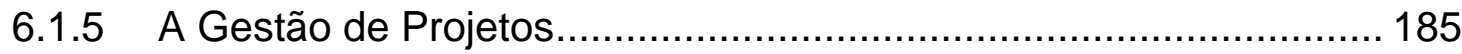

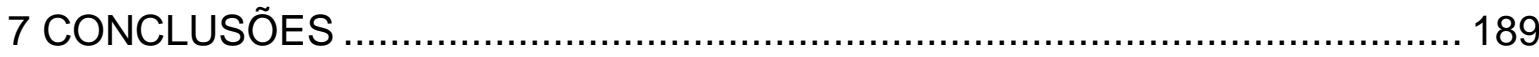

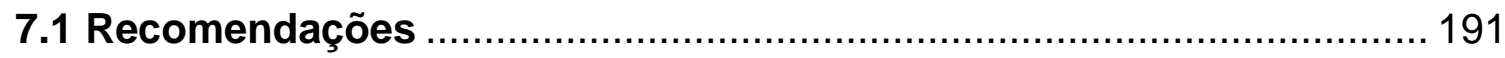

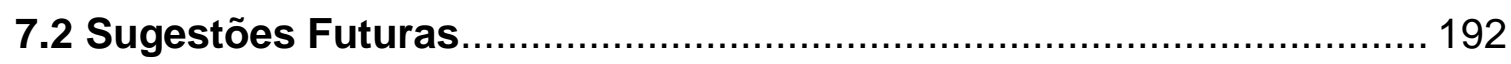

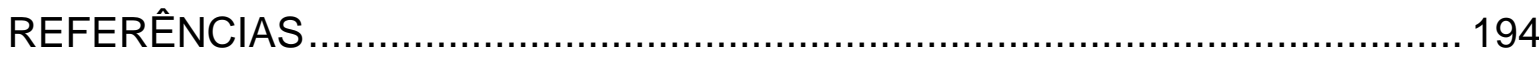

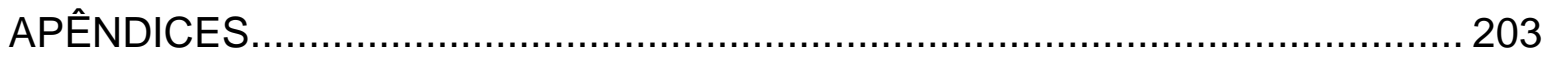




\section{INTRODUÇÃO}

\subsection{ContextualizaÇÃo}

De acordo com FIESP (2016), o setor da Construção Civil tem uma cadeia produtiva muito ampla, podendo ser estimado em 12,5 milhões o número de profissionais atuantes no setor. Isso representa $13,7 \%$ da população ocupada do país. Apenas 6,2 milhões desses profissionais atuam com carteira assinada (sendo 13,4\% da força de trabalho total do Brasil), conforme o Gráfico 1.

Gráfico 1 - Profissionais atuantes na Construção Civil total e com carteira assinada

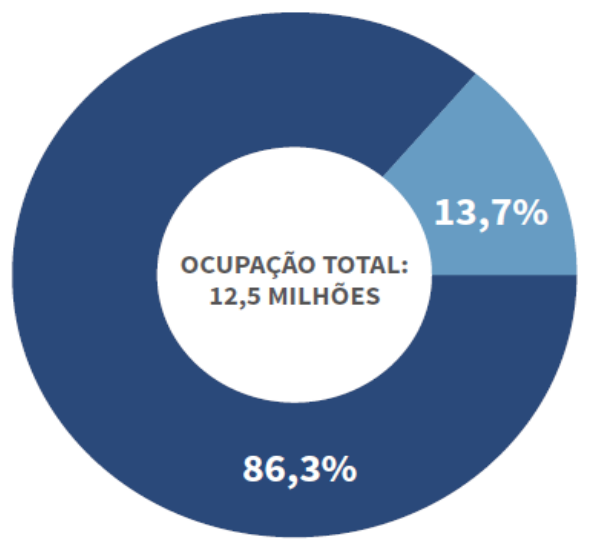

Cadeia produtiva da construção

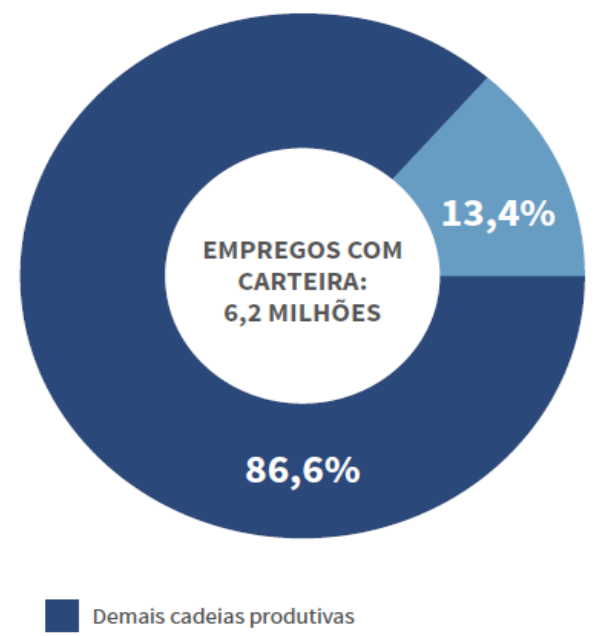

Demais cadeias produtivas

Fonte: FIESP (2016)

Segundo o SINDUSCONSP (2015), o setor da Construção Civil é um dos principais componentes de investimento do país, portanto a sua produtividade é uma questão fundamental para o crescimento econômico. De acordo com CBIC (2017b), o setor da Construção Civil representa, aproximadamente, 10\% do Produto Interno Bruto (PIB) brasileiro, o que demonstra a sua grande relevância para a economia e, portanto, a importância da melhoria dos seus processos e ferramentas.

Apesar da sua importância, o setor da construção apresenta baixa produtividade quando comparado com os outros setores e essa diferença só tem aumentado durante os últimos dez anos. De acordo com o estudo realizado pela Fundação Getúlio Vargas (FGV) para o SINDUSCONSP (2015), a produtividade do setor da Construção Civil no Brasil é 31,7\% inferior à média da economia do país e representa apenas $30,5 \%$ da produtividade média do mesmo setor em outros países do mundo. 
Os motivos dessa baixa produtividade da indústria da construção não são claros, mas os autores Eastman et al. (2014) acreditam que algumas das possíveis causas sejam: empresas muito pequenas que não possuem recursos para investirem em tecnologia; os baixos salários para os operários da construção, além da contratação de imigrantes, o que faz com que não haja a busca por inovações que dispensem o trabalho manual, que está sujeito a erros e qualidade relativa; a falta de planejamento e automação do canteiro de obras; a baixa qualidade da comunicação entre os envolvidos, que ainda é baseada em papel; os processos fragmentados na indústria; dentre outras questões que resultam em uma série de erros e desperdícios.

A necessidade em aumentar a produtividade do setor da construção civil é urgente, devido ao aumento dos custos, às perdas de prazos constantes, aos impactos na rentabilidade, ao aumento da complexidade dos negócios e à carência de mão de obra especializada. (FERREIRA; ZANCUL, 2016)

Para SINDUSCONSP (2015), a discussão relativa à produtividade relacionada à competitividade é um consenso pelo mundo, destacando, assim, a importância para o aumento da competitividade do setor para superar os desafios de reduzir os desníveis de produtividade do mesmo em relação à média da economia brasileira e o de diminuir a diferença entre a produtividade da Construção brasileira e o mesmo setor dos países desenvolvidos.

Devido ao tamanho do setor e ao elevado número de empresas e profissionais atuantes nele, o aumento da capacidade competitiva é essencial para as empresas que querem se manter no mercado, principalmente no momento de crise econômica se vivencia no país. A competitividade é crescente em todos os ramos empresariais, portanto, para sobreviver é necessário inovar, utilizando-se de instrumentos e técnicas. (MELHADO; OLIVEIRA, 2006)

Para Cardoso (2005), o desenvolvimento organizacional e o tecnológico da cadeia produtiva da Construção Civil são fatores essenciais para aumentar a competitividade da indústria. Além disso, de acordo com o MCT (2000), as empresas do setor dependem de alguns fatores para ampliar a sua competitividade, dentre eles: a eficiência produtiva, o processo de desenvolvimento, a tecnologia aplicada nos processos e a capacidade de retroalimentar esses processos. 


\subsection{JUSTIFICATIVA}

Os autores Catelani e Santos (2016) afirmam que a indústria da construção civil é pouco eficiente e possui um volume substancial de dados e pessoas envolvidas, acarretando uma necessidade muito grande por inovação e mudanças. De acordo com Eastman et al. (2014), a cadeia da construção mundialmente tem identificado essa necessidade por melhorias e aumento da produtividade. Os esforços para inovar estão sendo desenvolvidos há mais de 20 anos e a modelagem paramétrica 3D está sendo a aposta para aumentar a eficiência das atividades do setor. Para o autor, com o Building Information Modeling (BIM) é possível construir digitalmente um modelo do empreendimento que contenha os dados essenciais para a construção dele, dando suporte a todo o ciclo de vida. A grande importância da cadeia produtiva da construção civil para a economia brasileira revela a necessidade crescente em inovação. Por esse motivo, o BIM representa uma grande oportunidade para as empresas da cadeia produtiva brasileira aumentarem a sua eficiência e a sua competitividade pelos processos mais concisos e ferramentas inovadoras.

O BIM é um conjunto de processos e métodos aplicados na concepção da ideia do produto, no desenvolvimento do projeto, na construção, no uso, na operação e na manutenção do empreendimento. Pode ser utilizado para a sustentabilidade do projeto, redução de custos e retrabalho em todas as etapas, viabilização do cumprimento de prazos, além de permitir a criação e o ensaio de cenários variados, dentre outras soluções. Essa ampla quantidade de possibilidades representa uma revolução no segmento, em que a plataforma BIM já é considerada padrão global e é essencial que seja absorvida pelos agentes da cadeia produtiva da Construção Civil, visando o aumento de produtividade do setor. (CBIC, 2017a)

A CBIC (2016b) resume definições do BIM de autores diversos na seguinte: uma das mais importantes inovações gerenciais dos últimos anos, que se trata de um novo paradigma para a indústria da construção civil, auxiliando diretamente no aumento da produtividade e, por consequência, no desenvolvimento da economia do país. A entidade explica que o BIM é uma plataforma capaz de contribuir para a melhoria do desempenho, da produtividade, da modernização e da competitividade das empresas de todos os portes e de todos os segmentos da cadeia produtiva da 
construção civil. Para o autor, sua abrangência de todo o ciclo de vida é aplicável às edificações e às obras de infraestrutura e indústrias. Portanto, essa instituição acredita que o BIM revolucionará o mercado brasileiro. Consequentemente, a disseminação do conhecimento e a adoção em nível setorial é um objetivo estratégico da Câmara Brasileira da Indústria da Construção (CBIC).

A McGraw Hill Construction (2014) relata que o Brasil é um dos países com maior perspectiva de crescimento na adoção do BIM na sua cadeia produtiva nos próximos anos. Dentre os países pesquisados, o Brasil é o que mais demorou a começar a utilizar esse método. 70\% dos agentes utilizam o BIM há apenas dois anos e desses, quase $60 \%$ possui nível de maturidade entre iniciante e moderado na adoção e uso desse método. A evidente necessidade por inovação não só tecnológica, mas em todos os processos do setor da Construção Civil, além de todo o potencial de melhoria na produtividade que a metodologia BIM representa, com perspectiva de crescimento da sua adoção na cadeia produtiva, motivou a realização desta pesquisa de mestrado.

Já existem diversas iniciativas governamentais e setoriais sendo desenvolvidas pelos eventos, encontros, palestras e discussões para fomentarem a disseminação do conhecimento em relação a esse método e prever a adoção do BIM na cadeia produtiva da Construção Civil brasileira. Alguns exemplos são o Plano Brasil Maior do governo, que previu a implantação do BIM nas obras do exército (NASCIMENTO; LÜKE, 2014), o desenvolvimento da NBR 15965 - Sistema de classificação da informação da construção (CATELANI; SANTOS, 2016), o lançamento da coletânea "Implantação BIM para Construtoras e Incorporadoras" em 2017 (SINDUSCONJP, 2016), a criação do Comitê Estratégico de Implementação do Building Information Modeling - CE-BIM em junho de 2017 pelo Governo Federal (MDIC, 2018b) e o lançamento da Estratégia BIM BR em maio de 2018 pelo Governo Federal.

Por esse tema estar em ascensão, o objetivo desta pesquisa é relatar como está sendo desenvolvido esse processo de adoção dentro de quatro grandes empresas de infraestrutura do país, quais são os desafios que estão sendo identificados pelos profissionais e por essas organizações, quais são os impactos no método de trabalho atual que estão sendo percebidos e, principalmente, se após a adoção do BIM houve percepção na melhoria da produtividade da empresa. Além disso, procurou-se esclarecer que não há uma maneira única de se realizar a 
implantação do BIM nas empresas, mas que existem melhores práticas e estágios que devem ser seguidos para que o procedimento dessa evolução seja eficiente, conforme relatado em diversas referências bibliográficas, como: Eastman et al. (2014), Manzione (2013), Kassem e Amorim (2015), GSA (2017), CIC (2010) e CBIC (2016b).

Esta pesquisa ainda é importante para deixar registrado os pioneirismos das implantações nas grandes empresas de infraestrutura do setor brasileiro, visto que não há bibliografia desenvolvida nesse sentido e evidenciar os melhores caminhos para o processo de implantação do BIM.

\subsection{BJETIVOS}

\subsubsection{Objetivo Geral}

O objetivo deste trabalho é registrar, analisar e avaliar os processos de adoção do BIM que estão sendo realizados em quatro empresas de grande porte de infraestrutura e são muito relevantes para a economia brasileira, com foco na preparação dos profissionais e na mudança do processo de trabalho. Pretende-se apontar o que não surtiu efeito e o que trouxe resultados positivos durante 0 andamento dos diferentes métodos de cada empresa, além de identificar os recursos e as técnicas utilizadas em cada uma delas. Ainda serão analisados os impactos causados nas organizações, os desafios enfrentados e as oportunidades descobertas.

Essa pesquisa não tem o objetivo de explorar a fundo as ferramentas utilizadas pelas empresas ou a questão da interoperabilidade, mas sim o processo de adoção do BIM, entendendo apenas quais são as ferramentas treinadas pela equipe ou se conseguiram atingir o objetivo da interoperabilidade. 


\subsubsection{Objetivos Específicos}

Os objetivos específicos desta pesquisa são os seguintes:

a) Analisar os melhores caminhos e os métodos de implantação registradas na bibliografia;

b) Registrar como estão sendo desenvolvidos os processos de adoção do BIM nas quatro companhias participantes desta pesquisa;

c) Relatar os resultados obtidos pelas organizações até o momento e as tentativas que não tiveram resultados positivos;

d) Estudar as ações e as etapas que essas empresas estão realizando e confrontar com a bibliografia pesquisada;

e) Identificar questões relativas à Gestão de Projetos, Planejamento, Rejeição à Mudança e Melhores Práticas. 


\section{MÉTODO DE PESQUISA}

Com o propósito de alcançar os objetivos deste trabalho, a abordagem adotada foi a pesquisa qualitativa. Com essa abordagem, optou-se pelo método da pesquisa exploratória, que teve como objeto a pesquisa bibliográfica, seguida de quatro estudos de caso, nos quais foram feitas as descrições dos fatos relatados pelos profissionais entrevistados e, por fim, uma análise crítica dos resultados obtidos. A Figura 1 ilustra o fluxograma das atividades desenvolvidas para este estudo.

Figura 1 - Fluxograma da Pesquisa

Revisão Bibliográfica

\section{Estudos de}

Caso (4)
Análise Crítica dos Resultados
Revisão

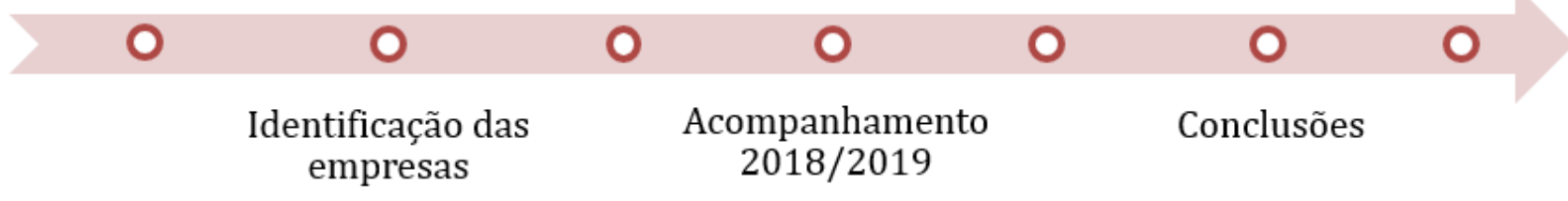

Fonte: A autora (2018)

\subsection{ABORdAGEM e PROPÓSITO dA PESQUISA}

De acordo com Gerhardt e Silveira (2009), a abordagem da pesquisa qualitativa se refere ao aprofundamento da compreensão de uma organização, buscando explicar o porquê das coisas, dando importância à compreensão das relações sociais, dos motivos, dos processos e dos fenômenos que não podem ser quantificados. Silva e Menezes (2005) definem a abordagem da pesquisa qualitativa como descritiva, na qual o ambiente natural é a fonte para a coleta de dados e o processo e seu significado são os focos principais do estudo.

Segundo Freitas e Prodanov (2005), a pesquisa exploratória tem o propósito de trazer mais informações sobre o tema, possibilitando o seu delineamento, a fixação dos objetivos e a formulação das hipóteses. A pesquisa exploratória desenvolvida proporciona um aprofundamento do tema a partir do levantamento bibliográfico e entrevistas com os profissionais que tiveram experiências práticas com o problema pesquisado. (SILVA; MENEZES, 2005) 


\subsection{Pesquisa biblográfica}

A pesquisa bibliográfica é elaborada com base em materiais já publicados, como por exemplo livros, artigos e revistas, conforme descrito por Freitas e Prodanov (2005), Zanella (2011) e Silva e Menezes (2005). Esse procedimento traz o conhecimento do que já foi estudado sobre o assunto, auxilia na contextualização e é imprescindível para todo trabalho científico. (FONSECA, 2002, p. 32 apud GERHARDT; SILVEIRA, 2009). Para essa pesquisa foram desenvolvidas revisões bibliográficas referentes aos temas relevantes para o estudo e para a contextualização do assunto.

Com base na pesquisa bibliográfica foi possível escrever o artigo "Os desafios e os esforços da cadeia produtiva da construção civil para a adoção do BIM", Freitas, Melhado e Cardoso (2018). Esse trabalho teve como finalidade levantar e analisar os obstáculos enfrentados pelos agentes do setor relacionados a cinco fatores principais: tecnologia, profissionais, organizações, comunicação/gestão e processos, além de explorar, também, as oportunidades e os esforços que estão sendo realizados pela cadeia produtiva para fomentar a adoção e o uso desse método. Esse artigo foi aceito e apresentado no ENTAC 2018 - XVII Encontro Nacional de Tecnologia do Ambiente Construído, e consta no Apêndice A desta dissertação.

\subsection{ESTUDOS DE CASO}

Conforme relatado por Yin (2015), o método de estudo de caso é ideal para pesquisas nas quais as questões centrais são "como" ou "porque", sendo o estudo sobre um fenômeno atual, no qual a pesquisa necessita de uma descrição ampla e profunda sobre o mesmo e em que o pesquisador não possui controle sobre os eventos comportamentais. Essa é uma técnica que ajuda na compreensão dos fenômenos individuais, organizacionais, sociais e políticos, que muitas vezes são complexos, porém, são passiveis de compreensão total a partir das investigações dos estudos de caso que são utilizados quando não há o intuito de alterar comportamentos, preservando as características do ambiente e dos acontecimentos da vida real. 
Segundo Yin (2001), o método atinente ao estudo de caso pode ser utilizada para entender um evento que provocou uma mudança organizacional, mostrandose tal técnica consideravelmente adequada para a presente pesquisa. Uma das fontes mais importantes para esse método concerne às entrevistas, que permitem uma conversa fluida por questões que seguem uma linha de investigação consistente com as informações a serem coletadas (YIN, 2015).

Com a finalidade de entender o processo de adoção do BIM nas empresas de infraestrutura do país foi selecionada uma amostra de quatro organizações, levando em consideração as seguintes questões:

a) Ramo de atuação - foram selecionadas apenas empresas que atuam no setor de infraestrutura, visto que esse é o recorte da atual pesquisa;

b) Tamanho da empresa - foram selecionadas apenas companhias de grande porte, tendo em vista a pesquisa sobre o processo de adoção do BIM como processo empresarial e na mudança causada no processo de trabalho da organização;

c) Representatividade no Setor - as empresas escolhidas têm grande representatividade do setor da construção civil, tendo em vista o seu tamanho e potencial de influenciar as outras organizações do setor;

Após a definição das empresas foram realizadas diversas entrevistas durante os anos de 2018 e 2019 para entender as suas experiências desde o início do processo de adoção do BIM, o que está sendo vivenciado, e os próximos passos da organização. Foram realizados também levantamentos documentais para a coleta de dados complementares. Todas as entrevistas efetuadas para o desenvolvimento deste trabalho foram gravadas com a autorização dos participantes e estão disponíveis para consulta sob solicitação e aprovação dos mesmos, visto que as empresas optaram que os seus nomes permanecessem confidenciais. Foram trocados também e-mails para a complementação de informações.

Com base nas entrevistas realizadas foi escrito também o artigo "O processo de adoção do BIM em uma construtora de grande porte de São Paulo" (FREITAS; MELHADO, 2018). Este trabalho relatou parte da experiência de adoção e utilização do BIM por uma das construtoras entrevistadas para esta pesquisa, o artigo consta no Apêndice B desta dissertação e também foi aceito e apresentado no ENTAC 2018. 
As entrevistas foram realizadas com os profissionais das empresas responsáveis pelas áreas de implantação e desenvolvimento BIM e com os profissionais atuantes nelas. Como base para as perguntas, foi utilizado um questionário desenvolvido a partir das informações relevantes identificadas durante a revisão bibliográfica. As perguntas não se restringiram apenas àquelas constantes no questionário.

\subsection{ANÁLISE CRÍTICA DOS RESULTADOS}

A partir da revisão bibliográfica e das informações coletadas e analisadas pelas entrevistas e levantamento documental, foi desenvolvida uma análise crítica dos processos de adoção do BIM nas empresas, implantação do método e a gestão desses projetos. Ainda foi estudada a reação dos profissionais em relação à mudança que o BIM representa para o seu processo de trabalho e como as empresas prepararam esses profissionais para esse evento.

Também foi avaliado nesta etapa o nível de maturidade BIM em implantação, o nível de conhecimento BIM, tanto dos profissionais entrevistados, como das empresas e a preparação dessas para adotar o método BIM. Foram identificados os procedimentos de adoção da metodologia BIM que seguem ou contradizem as sugestões propostas na bibliografia e, em seguida, foram analisados os sucessos e as falhas nesse processo em cada empresa.

A análise dos resultados é feita separadamente para cada empresa, relacionando os acontecimentos com o que está de acordo ou contra as informações levantadas na bibliografia. Ainda foi feita uma análise cruzada entre as experiências dessas quatro empresas para a identificação de comportamentos, pontos de vista, erros e oportunidades. Nessa segunda etapa foi possível perceber os caminhos em comum, os resultados semelhantes bons e ruins e analisar os motivos.

\subsection{ESTRUTURA DO TRABALHO}

Este trabalho está estruturado em sete capítulos. O primeiro capítulo se refere à introdução do trabalho, que realiza a contextualização do problema de 
pesquisa, a delimitação do cenário em que o estudo se encaixa, os objetivos gerais e específicos desta dissertação, além da sua justificativa.

O segundo capítulo compreende as questões referentes ao método de pesquisa e as formas utilizadas para coletar os dados e desenvolver esta pesquisa, as limitações do trabalho e a estrutura dele.

O terceiro capítulo traz toda a revisão bibliográfica consultada e as informações relevantes para este trabalho, que foram identificadas nelas. Nesse capítulo foram coletadas informações referentes aos temas relevantes para o embasamento desta pesquisa.

O quarto capítulo tem o objetivo de caracterizar as empresas objeto dos estudos de caso e relatar a experiência vivenciada por elas e pelos seus profissionais durante o processo de adoção do BIM.

O quinto capítulo apresenta uma análise crítica das experiências individuais de cada empresa, baseada na revisão bibliográfica. Identificando o que a bibliografia indica para ser feito, o que cada organização fez e comparar os resultados disso.

O sexto capitulo apresenta a discussão dos resultados, no qual foi feita uma análise em conjunto das experiências similares das empresas e compara com a bibliografia.

O sétimo Capítulo exibe as considerações finais e as conclusões da autora referente a tudo o que foi pesquisado e observado durante o desenvolvimento deste trabalho. São apresentadas as recomendações e sugestões para os futuros estudos acerca do tema.

No fim da dissertação são listadas as referências e apresentados os apêndices. 


\section{REVISÃO BIBLIOGRÁFICA}

\subsection{Building Information Modeling - BIM}

Existem diversas conceituações do que é o BIM e do que ele representa (MORDUE; SWADDLE; PHILP, 2016). A sua definição ainda não é consensual, portanto, neste trabalho serão identificadas apenas aquelas mais relevantes para a conceituação do BIM como método e processo organizacional, ao invés de apenas tecnologia.

O conceito do que é BIM vem se formando há, aproximadamente, trinta anos, porém, o termo se popularizou há poucos anos e, finalmente, está mudando a forma de pensar e produzir da indústria de Arquitetura, Engenharia e Construção - AEC. Ao contrário do que alguns autores afirmam, o BIM é uma atividade humana a ser desenvolvida, o que gera mudanças profundas nos processos existentes, transformação no produto final do setor e evoluções no processo de produção sendo, portanto, mais do que apenas softwares e ferramentas. O BIM é então um conceito composto por abordagens, métodos e tecnologias, que representa muito mais do que uma nova forma de modelar ou projetar. Ele significa uma mudança de paradigma para toda a indústria da construção (EASTMAN et al., 2014).

Para os autores Mordue, Swaddle e Philp (2016), o BIM é o processo de combinar informações e tecnologia para criar a representação digital de um empreendimento, que depende de diversas ferramentas para serem aplicadas e que se baseia em uma série de documentos de padronização e protocolos para atingir os melhores resultados. Para Abdelmohsen (2012), o BIM resulta em um processo no qual todos os participantes, as práticas, os sistemas e as estruturas de negócios conversam para maximizarem a eficiência.

Para CBIC (2016a), o BIM é um método de gerenciamento e projeto muito mais eficaz, composta por um conjunto de políticas, processos e tecnologias, capaz de auxiliar em diversas etapas de todo o ciclo de vida de um empreendimento, desde a sua concepção até o seu uso. É um processo progressivo que utiliza plataformas digitais e modelagem orientada a objetos, permitindo o armazenamento de informações, a troca facilitada desses dados, a comunicação simplificada entre a equipe e o fácil acesso à informação por todas as partes envolvidas. Kamardeen (2010) explica que o BIM é mais do que o modelo virtual do empreendimento, é um 
repositório inteligente dos componentes da construção, com seus atributos e relacionamentos documentados dentro desse modelo, que pode ser utilizado para fazer estudos de viabilidade, análises de custo, construtibilidade, sustentabilidade, planejamento de canteiro para excelência operacional, dentre outros usos.

Succar e Kassem (2016) conceituam que o BIM é um domínio do conhecimento que está em expansão, que fomenta a mudança nos processos e que impacta o produto final, os relacionamentos entre os agentes e os papeis dos profissionais do setor. Também afirmam que o BIM é um conjunto de tecnologias, processos e normas que alteram o produto da indústria da Construção, os papeis e os relacionamentos entre os profissionais (SUCCAR; KASSEM, 2015).

O AIA (2008) define que os modelos BIM possuem níveis de detalhamento de acordo com o nível de desenvolvimento para cada elemento do modelo e de acordo com a fase do projeto. Cada nível de detalhamento ou Level of Detail - LOD possui determinados requisitos e conteúdo, sendo do mais básico (LOD 100) até o mais detalhado (LOD 500).

Para Mordue, Swaddle e Philp (2016) e Eastman et al. (2014), com o BIM é possível construir digitalmente um modelo do empreendimento integrando as informações de diferentes fontes e envolvidos, centralizando todos os dados necessários do ciclo de vida, permitindo o compartilhamento entre todos os envolvidos, conforme a Figura 2. 
Figura 2 - O fluxo da informação com o uso do BIM

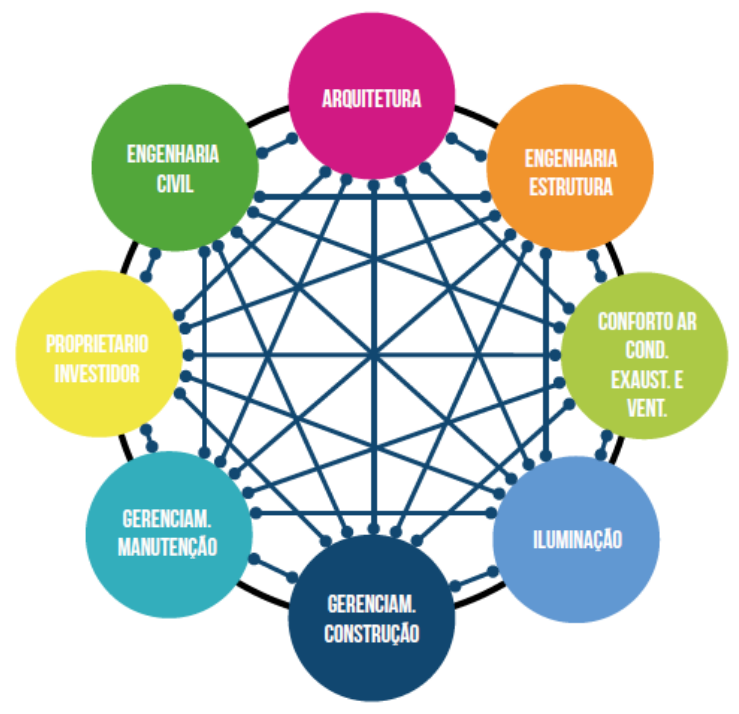

CAOS DE INFORMAÇÕES

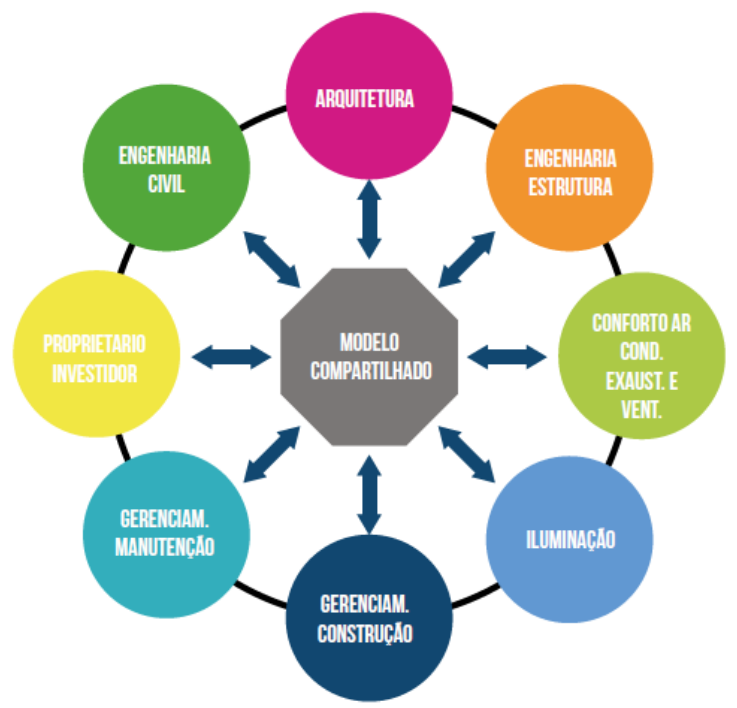

INFORMAÇÕES COMPARTILHADAS

Fonte: CBIC (2016a)

De acordo com estudos de Azhar (2011), o BIM tem a capacidade de aumentar a produtividade e a qualidade, além de diminuir os custos e o tempo dos projetos, que são viabilizados pela simulação do empreendimento em um ambiente virtual no qual é possível caracterizar a geometria do modelo, os quantitativos, o custo, os materiais, as propriedades dos elementos construtivos, o relacionamento espacial entre os componentes e a ordem cronológica de construção.

Entretanto, para Sacks (2012, apud MANZIONE, 2013), não é o BIM que toma as decisões, são os profissionais. Dessa forma, ele é mais um exercício social do que um exercício técnico, no qual a colaboração e a cooperação entre os profissionais são fundamentais para o BIM prosperar, de acordo com o autor. Por consequência, o BIM se transformou em um método de tomada de decisões, de diminuição de incompatibilidades e de redução de desperdícios. Apesar de muitas vezes ser confundido como uma evolução do CAD (Computer-Aided Design, Desenho Assistido por Computador), o BIM é um conceito totalmente inovador e abrange muito mais do que apenas a representação do empreendimento. 


\subsubsection{Dimensões e usos do BIM}

O BIM é aplicável a todo o ciclo de vida de um empreendimento, começando na conceituação de uma ideia, desenvolvimento do projeto, análise de desempenho, construção, manutenção do empreendimento, retrofit, dentre outros aspectos (CBIC, 2016a). A abrangência de soluções BIM é ampla e Kamardeen (2010) intitula essa capacidade como nD, ou seja, " $n$ " dimensões de possibilidades devido às extensões do BIM que se incorporam às diversas necessidades geradas pela modelagem de informações e são importantes durante todo o ciclo de vida do empreendimento, como: planejamento do tempo, acessibilidade, sustentabilidade, economia de energia, orçamentação, dentre outros fatores. Cada uma dessas dimensões retrata as principais funções do método e os softwares podem ser particularizados para tais aplicabilidades.

De acordo com Smith (2013), as dimensões são 3D - Modelo Orientado a Objetos; 4D - Tempo; 5D - Custo; 6D - Operação; 7D - Sustentabilidade e 8D Segurança. Neste trabalho foram adotadas essas definições para as dimensões, existindo uma inversão entre a sexta dimensão e a sétima, verificada em algumas referências bibliográficas.

A CBIC (2016a) esclarece que nem toda modelagem 3D é BIM. Para ser considerado BIM é necessário conter outras informações além de apenas a geometria do empreendimento. São exemplos disso os softwares que a partir das referências $2 \mathrm{D}$ emulam o modelo tridimensional, mas não viabilizam extração de quantitativo, nem a realização de simulações. Ainda há aqueles que proporcionam a modelagem 3D, mas os objetos não são paramétricos, portanto, não realizam atualizações automáticas e não possuem banco de dados com informações sobre o modelo. Em vista disso, o uso da modelagem tridimensional BIM só é viabilizado por softwares que possuem banco de dados integrados, que possibilitam a extração de quantitativos, tabelas, relatórios ou documentos e que atualizam automaticamente o modelo como consequência das revisões e modificações.

Eastman et al. (2014) explicam que a modelagem paramétrica permite a inserção de regras no modelo referente à geometria e ao relacionamento entre os objetos, além de parâmetros e características não geométricas, sendo isso o que viabiliza a atualização automática de todas as instâncias quando há alterações no modelo, a interface com as análises posteriores, as extrações de quantitativos, 
dentre outras funções. Essa capacidade do BIM permite a modelagem da criação de objetos paramétricos personalizados para a criação de geometrias complexas que antes eram impraticáveis.

A dimensão do 3D permite a completa compreensão do empreendimento, independentemente da sua complexidade, sendo possível ver detalhes e visualizar muito melhor do que em projetos 2D, pois esses requeriam um mínimo de familiarização com os termos técnicos da construção civil e de imaginação para a leitura e compreensão das informações contidas. Além disso, com a centralização de todos os modelos das diversas disciplinas em um modelo único, chamado também de modelo federado, é possível realizar a checagem de incompatibilidades (em inglês clash detection), em que os softwares geram relatórios, identificando automaticamente quando duas massas ocupam o mesmo espaço, podendo ser compartilhadas com os envolvidos para resolução. Alguns softwares identificam ainda as interferências funcionais (em inglês soft clash), que se refere ao espaço que um determinado equipamento ou dispositivo necessita para operar. Isso é identificado a partir da inserção de regras de verificação admitidas em determinadas ferramentas (EASTMAN et al., 2014), (CBIC, 2016a).

Outra funcionalidade viabilizada pelo 3D é a possibilidade de gerar documentação mais rápida, consistente e com informações mais íntegras. Um exemplo disso é a capacidade de atualizar automaticamente as vistas, cortes e plantas, quando modificações são incorporadas ao modelo, sendo que isso é viabilizado devido aos objetos contidos na modelagem serem paramétricos e inteligentes, possuírem características de relacionamento com as outras partes do empreendimento e com o entorno. (CBIC, 2016a)

Suzuki e Santos (2015) definem que o 4D é a capacidade de unir o cronograma aos modelos tridimensionais e, a partir disso, visualizar o cronograma proposto para a obra, o sequenciamento da mesma e o avanço real. Com isso é possível prever e monitorar os prazos com maior controle, acompanhar melhor os avanços e os desvios na execução. Para CBIC (2016a), a quarta dimensão se refere ao Planejamento ou Sequenciamento 4D, sendo possível detalhar todas as etapas e atividades previstas para a execução da obra. Isso também é chamado de Construção Virtual, no qual antes de começar a obra física é possível ensaiá-la de diversas maneiras para verificação e estudo. 
É possível então incorporar informações ao modelo 3D referentes ao método de construção e ao sequenciamento das atividades. Com o modelo 4D é possível simular a construção e identificar erros no sequenciamento das atividades, visualizar o fluxo de trabalho, planejar a periodicidade de suprimento de recursos para minimizar desperdícios em obra, simulação de cenários para estudo e planejamento em logo prazo, planificação de canteiro e seu reposicionamento ao longo da obra, identificação de erros de planejamento e cálculo do tempo necessário de uso dos equipamentos alugados (BIOTTO; FORMOSO; ISATTO, 2012). Os estudos de Suzuki e Santos (2015) identificaram que o 4D é utilizado principalmente pelos construtores nas etapas de planejamento, execução e acompanhamento da obra.

De acordo com Kunz e Fischer (2009), a quarta dimensão é a visualização do produto durante o processo de construção, sendo isso possível a partir da combinação do modelo 3D com o cronograma da obra. Os modelos 4D mostram a construção pelo tempo, sendo possível que todos os envolvidos visualizem esse sequenciamento em uma animação 4D, na qual a identificação efetiva de problemas de planejamento e interferência de tempo-espaço é simplificada.

Para RICS (2015), o 5D é a capacidade de realizar o orçamento da construção proveniente da inserção das informações relacionadas aos custos da obra no modelo 3D. Enquanto o BIM continua a crescer globalmente, é crucial que os agentes da indústria da construção entendam a utilização do BIM nas atividades de orçamentação, gestão dos custos da construção e gestão de projetos. Para Smith (2013), a quinta dimensão está relacionada à gestão do custo da construção, que é viabilizada pela extração de quantitativos do modelo 3D, sendo que as vantagens competitivas desse uso já foram percebidas pelos agentes da indústria da construção e estão sendo realizadas por diversos profissionais da cadeia produtiva, como engenheiros de custo, projetistas, economistas da construção e gestores de projeto e obra. Para o autor, o planejamento do custo da construção a partir do modelo 3D depende muito da qualidade em que ele foi concebido. Muitas vezes eles não são criados com todas as informações necessárias devido ao valor desse desenvolvimento ou com informações inadequadas e até mesmo incorretas. 
Mitchell (2013) destaca que para realizar o planejamento de custos da construção - 5D pelo Modelo 3D, o nível de detalhamento mínimo dele deverá ser 300. Outro quesito muito importante para o controle dos custos da construção é que, além do planejamento dos custos no início da construção realizado pela extração de quantitativos do modelo 3D, os envolvidos deverão ter um retorno em tempo real em relação ao que foi planejado versus o que está sendo realizado, para que o controle seja efetivo. CBIC (2016a) indica que a extração automática das quantidades de serviços e componentes dos modelos BIM garante precisão agilidade e consistência nas informações. Essa extração pode ser feita também de acordo com as fases definidas no planejamento 4D, se houver um cronograma de atividades associados ao modelo 3D.

As dimensões relacionadas à Sustentabilidade e à Gestão das Instalações são frequentemente alternadas entre 6D e 7D. RICS (2015) identifica a sexta dimensão como aquela capaz de realizar a gestão as instalações mediante a inclusão de informações variadas referentes ao gerenciamento do ciclo de vida do empreendimento. De acordo com Eastman et al. (2014), o modelo BIM pode ser utilizado para otimizar o gerenciamento e a manutenção das instalações já existentes, empregando o modelo as-built do empreendimento.

Assim, os proprietários dos empreendimentos podem utilizar o BIM de forma estratégica e efetiva para popular a base de dados de gerenciamento das instalações, principalmente em relação aos espaços existentes; gerenciar os ativos com o auxílio da integração de dados dos modelos das instalações e outros sistemas e planejar as modernizações ou manutenções das instalações. No Gráfico 2 podemos ver o valor agregado do modelo BIM à construção ao longo do ciclo de vida da edificação em comparação com os processos tradicionais, bem como o esforço de produção em cada uma das fases. 
Gráfico 2 - Valor agregado e esforço do processo BIM versus o processo tradicional

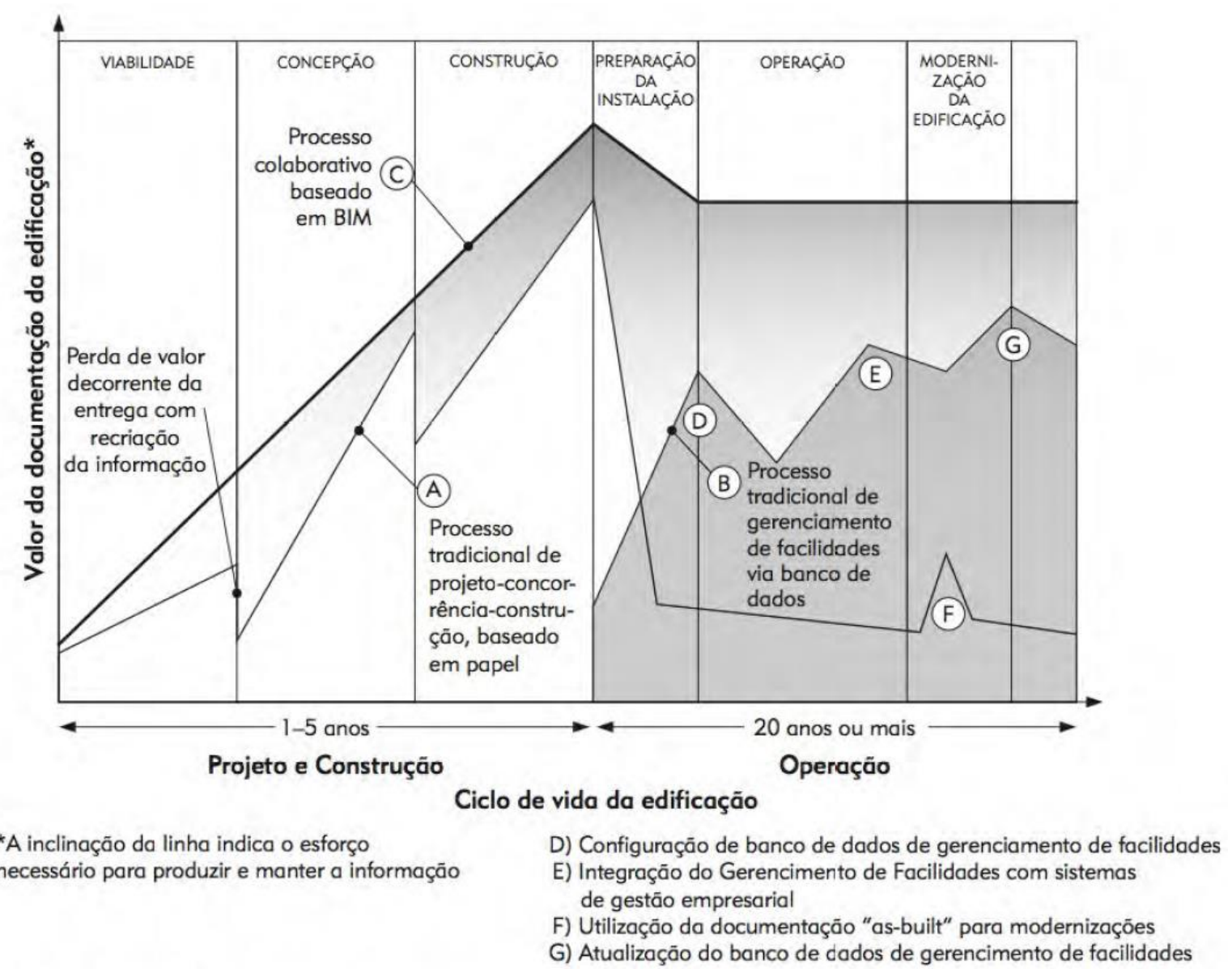

Fonte: Eastman et al. (2014)

Os resultados do estudo de CRC (2007) identificam o BIM como benéfico para a gestão de ativos. Com ele é possível realizar a recuperação e a armazenagem de dados e informações integradas relevantes para a manutenção e a gestão do empreendimento. O autor cita que com o modelo 3D BIM, é possível acrescentar dados que suportem todo o ciclo de vida do empreendimento e, especificamente para a gestão dos ativos, o modelo suporta informações operacionais que serão necessárias para essa finalidade. O produto da pesquisa do autor revelou que os processos de gestão das instalações são realizados mais rapidamente e mais efetivamente, uma vez que a informação é facilmente compartilhada com outros membros da equipe pelo modelo BIM.

A importância desse uso é evidenciada por Kelly et al. (2013), pois a fase operacional é a de maior custo do ciclo de vida de um empreendimento e existe uma necessidade econômica e ambiental muito grande, que demanda que a gestão dos empreendimentos seja realizada de uma maneira eficiente. As informações 
referentes a um empreendimento em uso são todas em papel, sejam os papeis de garantias dos equipamentos, fichas técnicas, lista de equipamentos, cronograma de manutenções preventivas, listagem de peças de reposição, dentre outras informações essenciais para realizar a gestão da operação. Por se tratarem de informações ainda baseadas em papel, os autores identificam que muitas vezes as informações contidas em tais documentos estão incompletas ou inadequadas. Por esse motivo, o uso do BIM durante todo o ciclo de vida do empreendimento pode ajudar na coleta dessas informações e na qualidade delas, reduzindo o tempo e o custo desse processo. Apesar de sua importância, os autores indicam que o conhecimento nessa área do BIM e os esforços de pesquisa e desenvolvimento tecnológico ainda são limitados.

As soluções BIM não param por aí. De acordo com Hardin e Mccool (2015) e CBIC (2016a), quando os componentes de sustentabilidade são incorporados ao modelo, os softwares ajudam os órgãos ambientais e profissionais a simularem comportamento e desempenho do empreendimento e das suas instalações, pelas análises de eficiência energética, conforto térmico, emissão de carbono, estruturais, luminotécnicas, de insolação e sombreamento. Também possibilitam a utilização de processos sustentáveis, tanto em relação à questão de gerenciamento e quantificação de entulho, como no uso de materiais adequados para uma determinada situação.

A gestão dos resíduos gerados pela construção civil é dificultada pela complexidade em quantificá-los, portanto, o BIM também pode ser utilizado para auxiliar nessa atividade, uma vez que as ferramentas ajudam na quantificação, na melhora dos processos e na implantação de planos de gestão com informações compartilhadas durante todo o ciclo de vida (CARVALHO; SCHEER, 2015). Cheng e Ma (2012) apresentam um novo sistema associado a um modelo BIM 3D capaz de estimar os resíduos de construção e demolição mediante a inserção de novas informações referentes à densidade, ao volume e ao peso. Os autores indicam que isso é possível pela extração de quantitativos na forma de listagem, que trazem diversas informações sobre cada componente da construção, inclusive as informações detalhadas de volume de cada elemento, tipo de material, volume de resíduos inertes e não inertes, dentre outras informações. 
Hardin e Mccool (2015) explicam que durante o design conceitual, com um nível de detalhamento 200 , os modelos BIM podem ser utilizados para analisarem a escolha da localização do empreendimento, a orientação dele para o ganho de calor, a direção do vento para garantir ventilação natural e na forma da edificação para permitir a luz natural e diminuir os gastos com energia. Após essa etapa, a entrada de novas informações no modelo e a associação de novos softwares é necessária para realizar análises mais detalhadas, como, por exemplo, a análise para identificar a quantidade de energia necessária para a operação do empreendimento, para verificar a autossuficiência da sua energia e para averiguar a quantidade de luz natural (HARDIN; MCCOOL, 2015; MOAKHER; PIMPLIKAR, 2012).

Existem ainda outras dimensões citadas por alguns autores, como, por exemplo, a questão do 8D relatada por Kamardeen (2010), que se refere à oitava dimensão como "segurança". O autor relata que o conceito do design seguro depende dos projetistas conduzirem uma análise dos riscos em cada um dos componentes projetados do empreendimento. Para fazer isso é necessária a integração de todas as informações inerentes à construção dentro do projeto. Para desenvolver um design seguro é preciso realizar investigações e análises para melhorar a prevenção dos perigos da construção. Essas questões devem se tornar parte do processo de projeto como ponto fundamental. A oitava dimensão então é desenvolvida com o BIM a partir da caracterização dos riscos dos elementos do modelo BIM, identificação de solução dos problemas de segurança levantados e desenvolvimento de propostas de controle de riscos no canteiro de obras para aqueles riscos incontroláveis identificados.

De acordo com Hardin e Mccool (2015), as questões de segurança utilizando - BIM estão sendo amplamente discutidas na indústria da construção e as atividades para se obter empreendimentos e construções mais seguras podem ser obtidas pela: a) da análise das proteções de guarda corpo a serem colocadas e retiradas durante a obra; b) de simulações 4D para verificar a logística do canteiro e identificar quais são os dias e quais as áreas que serão perigosas; c) de treinamentos de segurança e orientação sobre o canteiro com o modelo BIM para os operários; d) do aumento na pré-fabricação de componentes para a obra, para diminuir o tempo dos operários em escadas ou posições não seguras de trabalho. 
Além das dimensões do BIM citadas por diversos autores, foi documentado pela Penn State University os 25 usos mais comuns do BIM, conforme se verifica na Figura 3. Esse método pode agregar qualidade ao produto da cadeia produtiva da construção civil resultante dos seus diversos usos possíveis em cada etapa do processo, sendo eles divididos nas quatro fases do empreendimento: Planejamento, Projeto, Construção e Operação do Empreendimento. Esses usos foram identificados baseados em diversas entrevistas com especialistas da indústria da construção, análises de estudos de casos de implementação e revisões da literatura.

Figura 3 - Usos do BIM por etapas - Inglês

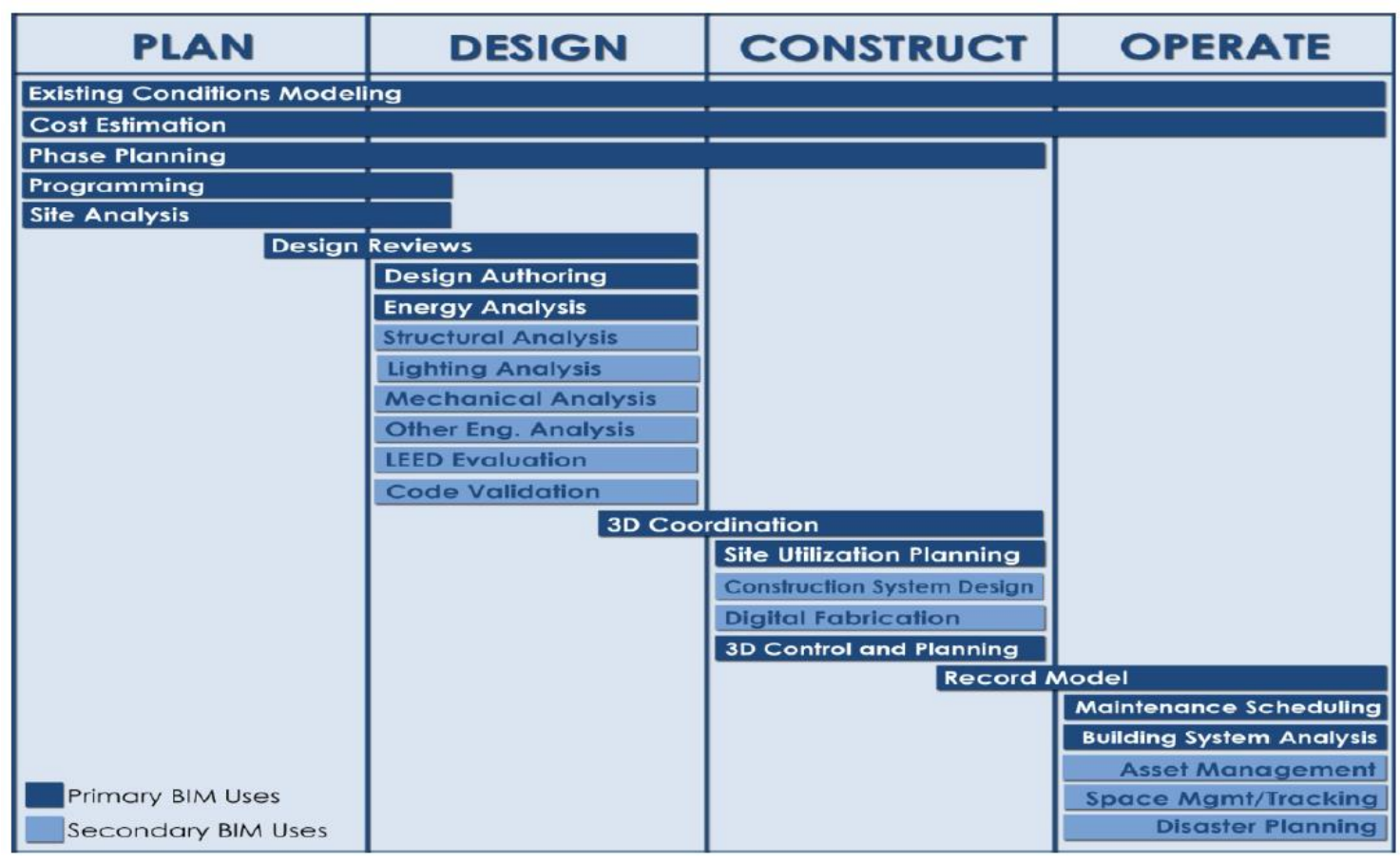

Fonte: CIC (2010)

A imagem produzida pela Penn State University foi traduzida pelo CBIC (2016d) na Figura 4. Ela traz os usos secundários e principais do BIM, os quais deverão ser escolhidos durante a fase de planejamento de cada projeto, de acordo com os seus objetivos, características e participantes. Cada projeto possui uma finalidade e, portanto, usos específicos do BIM para ele. Essa análise deve ser feita com atenção para não haver maior esforço no desenvolvimento do projeto ou da obra sem necessidade. 
Figura 4 - Usos do BIM por etapas - traduzido

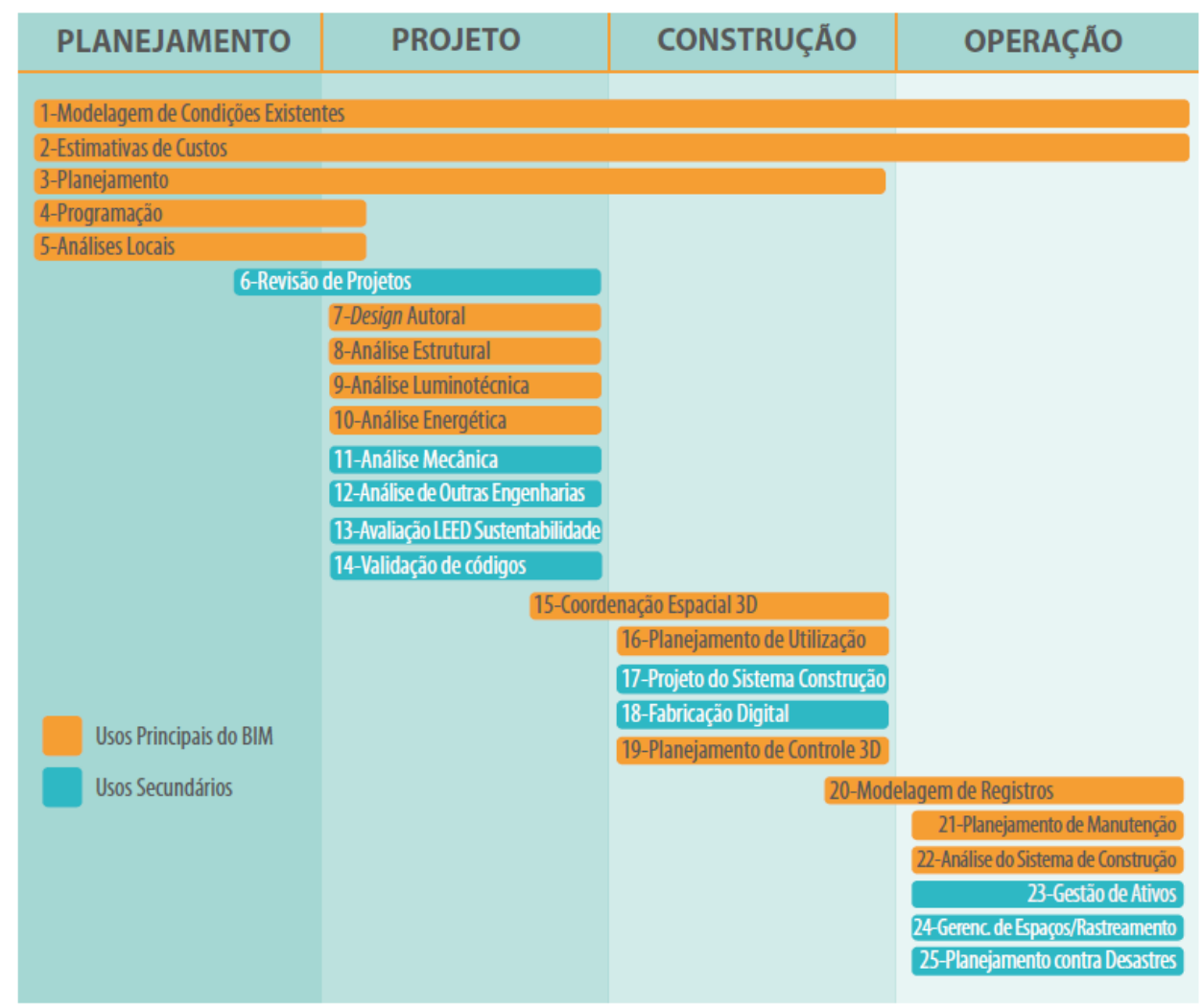

Fonte: CBIC (2016d)

A CIC (2010) explica que cada um desses usos possui potenciais benefícios, em caso de implementação e aplicação correta do método; habilidades necessárias dos membros da equipe para desempenhar aquele uso e os recursos precisos, como softwares adequados e informações mínimas. $O$ autor ainda ressalta a grande importância de começar com o fim na cabeça, ou seja, para uma implantação com sucesso do processo BIM é necessário planejar os usos e o caminho a ser trilhado, pensando no que se espera ao usar esse modelo daqui a alguns anos.

\subsubsection{Benefícios}

Os benefícios que o BIM traz para os vários processos da cadeia produtiva da construção estão cada vez mais evidentes globalmente. A McGraw Hill Construction (2014) relata que mundialmente $75 \%$ dos agentes reportaram um retorno positivo no investimento utilizando esse método nos seus processos. No Brasil esse número sobe para $85 \%$ (sendo $36 \%$ retorno muito positivo, $49 \%$ moderado e $15 \%$ sem retorno ou negativo). Ainda nas pesquisas, os agentes relataram que as maiores oportunidades que o método traz são a redução dos erros 
e as omissões durantes os processos de projeto e construção, a colaboração entre os agentes, a melhoria da imagem da empresa no mercado e a diminuição dos retrabalhos.

Para Eastman et al. (2014), quanto mais cedo o modelo for desenvolvido e compartilhado, mais útil ele será e maiores benefícios poderão ser incorporados ao empreendimento durante todo o ciclo de vida. Os diversos usos do BIM são possíveis se os softwares forem utilizados corretamente e o processo de trabalho estiver de acordo com o que for necessário para se trabalhar em BIM. Os autores Eastman et al. (2014) e a CBIC (2016f) indicam que esses usos podem trazer muitos benefícios, como:

a) Melhor visualização do empreendimento em qualquer etapa pelo cliente, pelos projetistas, construtores, subcontratados e todos os envolvidos no seu desenvolvimento;

b) Facilidade em instruir novos membros da equipe, empregando o modelo durante todas as fases, promovendo o entendimento;

c) As correções e modificações de projeto identificadas durante a obra podem ser rapidamente feitas, uma vez que existem regras paramétricas atreladas ao modelo. As atualizações são automáticas em todos as disciplinas, plantas e vistas;

d) Facilidade de compreensão do empreendimento e detecção automática de interferências principalmente em construções mais complexas, conforme se pode observar na Figura 5;

e) Diminuição de erros de projetos e omissões;

f) Maior confiabilidade e integridade nas informações do modelo 3D e dos desenhos 2D, pois todas as plantas e os cortes são gerados a partir da mesma fonte de dados;

g) O BIM ainda proporciona a colaboração entre todos os envolvidos no projeto;

h) Capacidade de se trabalhar simultaneamente em um mesmo modelo;

i) Diminuição da quantidade de conflitos de projetos entre as diversas disciplinas;

j) Proporciona melhor comunicação entre a equipe, pois todas as informações são compartilhadas com todos os envolvidos, independente da distância; 
k) Com o modelo é possível realizar a extração de quantitativos e desenvolver a estimativa de custos precisa em qualquer etapa do empreendimento e muito antes do que nos projetos em 2D;

I) Maior confiabilidade das estimativas de custos;

m) Aumento da sustentabilidade dos empreendimentos, em vista da facilidade em realizar análises com esse fim;

n) Aumento da qualidade do produto da indústria da Construção Civil;

o) Diminuição do tempo total de projeto;

p) Diminuição no custo de projeto e, consequentemente, no valor total do empreendimento;

q) Melhor planejamento, acompanhamento e gestão da construção com o Modelo 4D;

r) Maior compreensão dos objetivos diários da construção;

s) Melhoria do planejamento da equipe e dos equipamentos;

t) Detecção de conflitos, interferências e inconformidades de projetos antes da etapa de construção;

u) Diminuição da quantidade de retrabalhos durante a obra e, consequentemente, menores frustrações pelos envolvidos na obra;

v) O modelo pode servir de base para a fabricação de componentes prémoldados para a obra, como já é feito na fabricação de peças em aço. Assim, facilita-se a fabricação fora do canteiro e se reduz o tempo e os custos;

w) Com o BIM é possível também utilizar as ferramentas para empregar técnicas de construção enxuta, por uma coordenação minuciosa dos materiais e dos subempreiteiros para reduzir a necessidade de estoque de materiais e diminuir os desperdícios;

x) Identificação antecipada de problemas de segurança na obra;

y) É possível reduzir custos como planejamento preciso do cronograma, dos equipamentos, da chegada de materiais e da chegada de pessoal;

z) As análises desenvolvidas durante a fase de projeto podem servir para verificar a funcionalidade dos sistemas e dos equipamentos no decorrer dos anos;

aa) O modelo as-built pode servir para o monitoramento e o gerenciamento dos espaços, equipamentos e sistemas existentes; 
bb) Verificações de modernização ou manutenção das instalações podem ser facilmente ensaiadas para entender os impactos previamente;

cc) Aumento do valor do empreendimento devido às análises de desempenho realizadas em BIM;

dd) Otimização do gerenciamento e manutenção das instalações;

ee) Redução de tempo no cronograma total de projeto e construção.

ff) Contribuição também para a implementação de outras inovações nas empresas.

Figura 5 - Detecção de automática de interferências em construções complexas

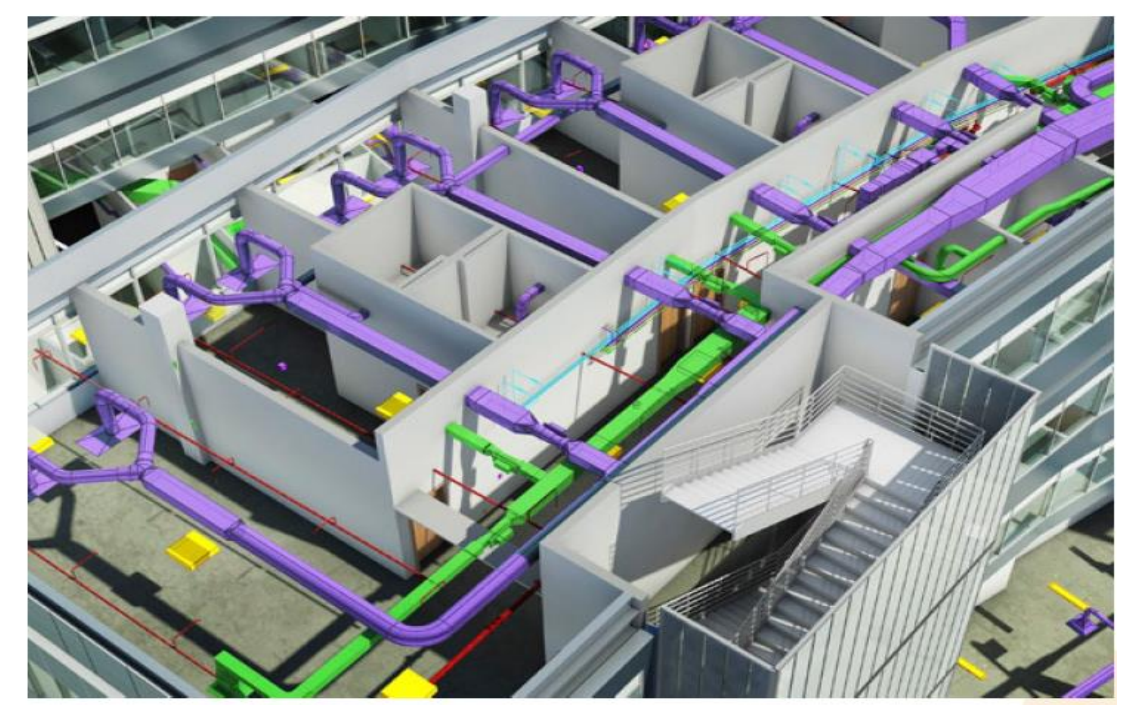

Fonte: CBIC (2016f)

O BIM pode representar uma diminuição dos custos, mas isso dependerá de quando o uso do método é incorporado ao processo. Essa relação da capacidade de influenciar o custo em relação à etapa do empreendimento pode ser analisada no Gráfico 3. Ainda nesse gráfico é possível verificar a influência do custo total do empreendimento durante o seu ciclo de vida, sendo evidenciado que se o BIM for incorporado ao processo logo no início, como nas etapas de projeto conceitual e estudo de viabilidade, a capacidade de influenciar os custos do empreendimento será a maior possível. Essa capacidade diminui à medida que o projeto evolui para as etapas de concepção e detalhamento. Quando se inicia a etapa de obra, o BIM já possui pouca capacidade de influenciar o custo, visto que as soluções construtivas e o detalhamento dele já foram definidos em etapas anteriores. 
Gráfico 3 - Capacidade do BIM em influenciar os custos até a entrega do empreendimento

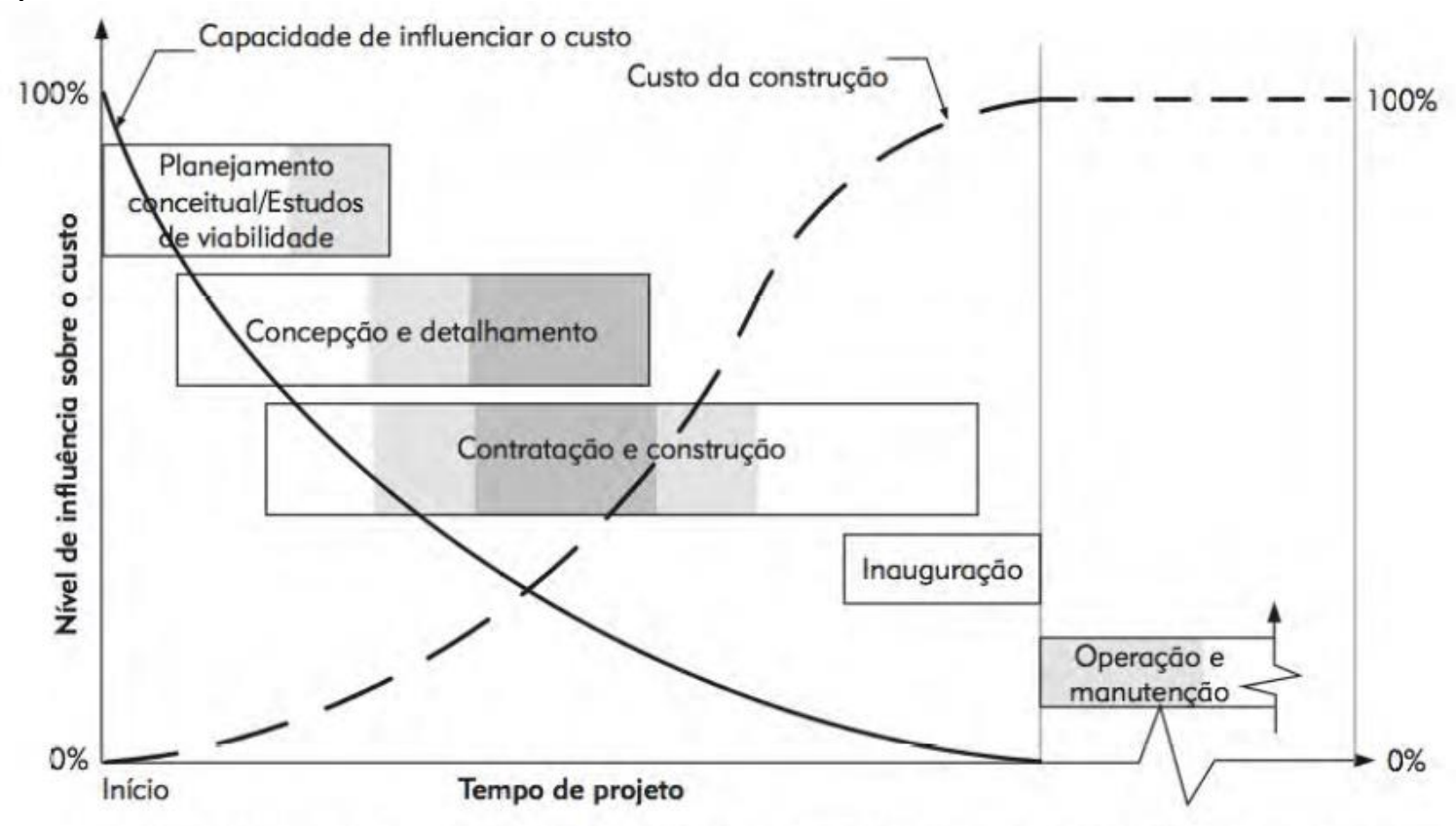

Fonte: Eastman et al. (2014)

De acordo com Biotto, Formoso e Isatto (2012), diversos são os benefícios proporcionados ao projeto e à gestão dos sistemas de produção pelo uso dos modelos BIM 4D, sendo eles o auxílio na tomada de decisão na gestão de sistemas construtivos, na diminuição de erros no caminho crítico das atividades, na otimização do uso dos equipamentos com o auxílio das simulações, no apoio à gestão dos espaços e das suas restrições pelo tempo. Os variados usos ajudam a diminuir os conflitos entre equipamentos, identificar os fluxos que interceptam outras atividades, antecipar interferências entre fluxos de trabalho, contribui com a melhora na gestão da obra e auxilia no planejamento do arranjo físico e logística do canteiro.

Além disso, a CBIC (2016a) destaca o benefício que a visualização do modelo 3D traz para a comunicação e para o entendimento do empreendimento pelas pessoas que não são da indústria AEC, como clientes e investidores; para a compreensão da obra pelos operários; para a comunicação e alinhamento de mudanças e durante reuniões de equipe. As animações 4D da construção servem para mostrarem aos leigos da construção civil, como os usuários, os vizinhos e os investidores, as fases que a obra percorrerá e o que pode ser esperado quando o empreendimento estiver concluído. Servem também para otimizarem 0 planejamento da construção, do cronograma, para engajarem todos os agentes envolvidos no processo, entenderem as interferências de espaço no tempo e 
identificarem interferência entre os trabalhos sendo desenvolvidos por subcontratados diferentes. (KUNZ; FISCHER, 2009)

Os maiores benefícios do 5D são evidenciados por Mitchell (2013), sendo eles: a capacidade de realizar diversas estimativas de custos no início do projeto, de acordo com vários designs e as diversas alterações que estão ocorrendo na concepção. Os custos são fundamentais para definirem se aquele projeto será ou não exequível. Além da capacidade de tomada de decisão mediante o planejamento dos custos de diversos cenários rapidamente, o que era inviável com os projetos em 2D devido ao imenso trabalho necessário.

Azhar (2011) relata que além de aumentar a colaboração entre as equipes, da melhoria na gestão e da melhoria nas relações com o cliente final, o BIM também traz um retorno no investimento considerável, sendo $634 \%$ nos projetos dos seus estudos de caso. Para CRC (2007), os benefícios de se utilizar o BIM para gestão dos empreendimentos já construídos são a consistência das informações, a inteligência dos modelos, a facilidade de visualização com a representação tridimensional e a facilidade de extração de relatórios para a manutenção e o gerenciamento. A CBIC (2016f) afirma que a quantidade de benefícios que o BIM traz é grande e, portanto, em breve, ele será mandatório para a indústria da construção civil.

Os maiores benefícios para Azhar, Hein e Sketo (2008) são um design melhor, com qualidade superior, processos mais rápidos e efetivos, análises mais rigorosas, rapidez nas simulações, performances de excelência, melhoria da sustentabilidade, maior controle nos custos durante todo o ciclo de vida $\mathrm{e}$ capacidade de possuir todas as informações do empreendimento centralizadas. $O$ relatório técnico anual do Centro de Engenharia de Instalações Integradas da Universidade de Standford relatou que os benefícios identificados nas suas pesquisas em 32 grandes projetos foram 40\% a menos de custos não previstos, estimativa de custos com precisão de 3\%, $80 \%$ de redução no tempo de desenvolvimento de um orçamento, economia de $10 \%$ do valor total da obra devido à identificação de interferências e redução de $7 \%$ do tempo total de projeto (AZHAR, HEIN; SKETO, 2008)

O sócio da empresa Sinco Engenharia, Paulo Sanchez, indica que após a adoção do BIM na sua empresa e nas suas obras, foi possível contatar uma redução nos custos totais em $4 \%$, pois devido ao melhor planejamento e acompanhamento 
das suas obras com o modelo 4D, elas não atrasaram mais (SINDUSCONJP, 2016). Ricardo Esteves, chefe do Departamento de Especificações Técnicas da Fundação para o Desenvolvimento da Educação (FDE), indica que as maiores vantagens do BIM são: capacidade de simulação do empreendimento, extração de quantitativos precisos, orçamentação simplificada, eliminação de incompatibilidade e retrabalhos, processos mais eficientes e produtivos, planejamento e fiscalização de obras, maior interação entre as disciplinas, transparência nos processos e simulação de diferentes cenários (SINDUSCONJP, 2016).

Com os usos e benefícios que o BIM potencialmente traz para o projeto do empreendimento, é possível antecipar as soluções construtivas, os potenciais retrabalhos e as tomadas de decisões para as fases iniciais de projeto básico e executivo, diminuindo o impacto do custo e do retrabalho na etapa de contratação e obra, conforme Gráfico 4.

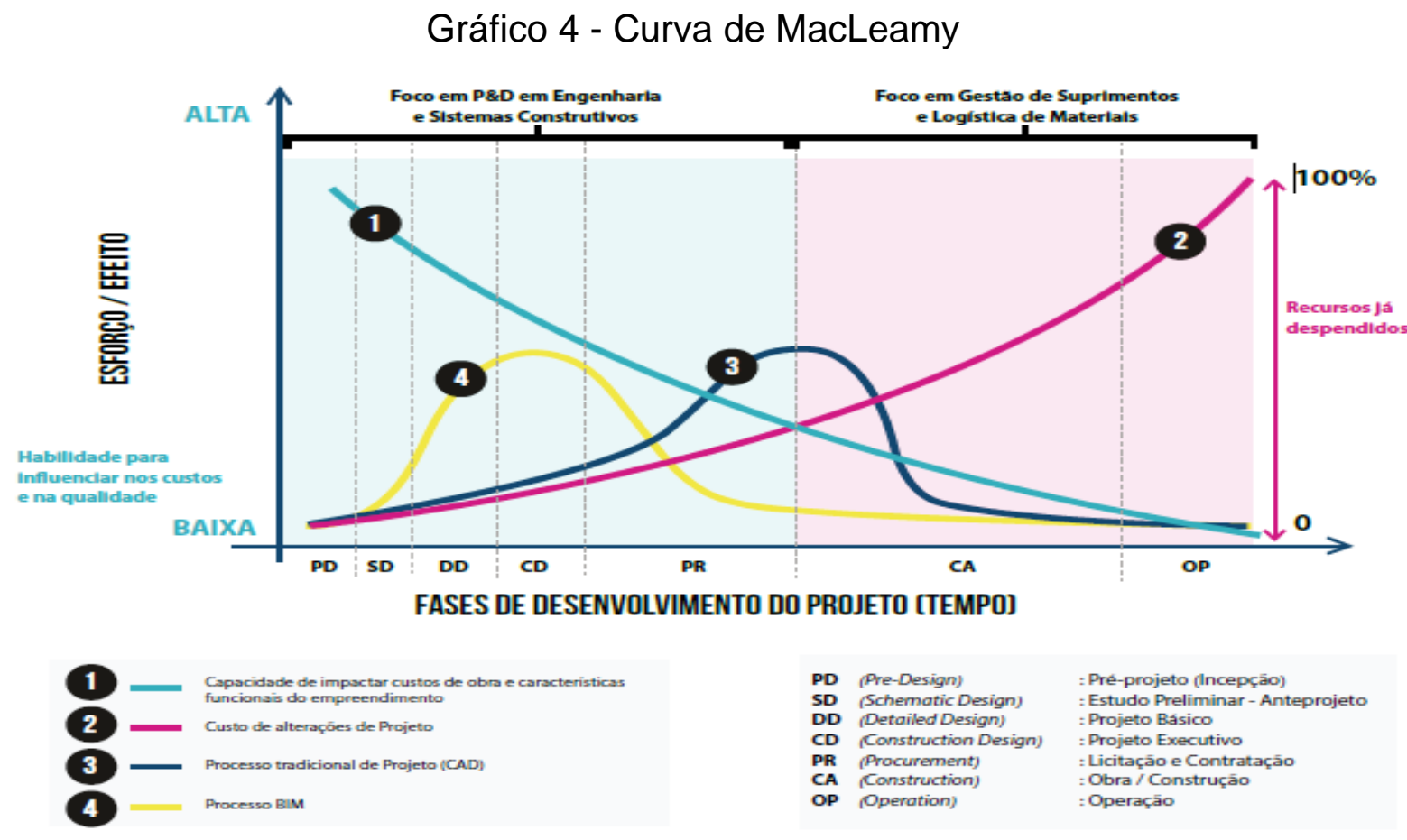

Fonte: CBIC (2016a) 


\subsection{O BIM NO BRASIL E NO MUNDO}

Conforme visto anteriormente, o BIM proporciona incontáveis oportunidades para a melhoria da produtividade e da economia em todas as fases da indústria da construção civil. Em razão disso, diversos países do mundo já adotaram o método e os seus processos e já estão utilizando há alguns anos.

Um exemplo disso é que desde 2003, o Departamento de Administração de Serviços Gerais (GSA) dos Estados Unidos estabeleceu pelo seu Serviço de Edifícios Públicos (PBS) o Programa Nacional 3D-4D-BIM. Esse programa auxilia os usos do BIM em todas as linhas de serviço do PBS e se transformou em uma colaboração com o Serviço de Tecnologia e Informação de Edifícios Públicos (PBITS) (GSA, 2017). Ainda nos Estados Unidos, em 2005 foi fundado o Conselho de Informação das instalações (Facility Information Council - FIC), que em 2008 se transformou no Comitê de Projetos BIM Nacional dos Estados Unidos, o NBIMSUS $^{\mathrm{TM}}$, que faz parte da buildingSMARTalliance ${ }^{\circledR}$, uma organização que contribui para a criação de ferramentas e padrões para a indústria $A E C$ do país, com 0 objetivo de melhorar as efetividades dos fluxos de trabalho baseados em colaboração. O projeto NBIMS-US disponibiliza gratuitamente os padrões estabelecidos para o uso do BIM na indústria da construção civil estadunidense.

O Reino Unido definiu no seu Plano Estratégico Governamental para a Construção de 2011 até 2015 que coordenaria o desenvolvimento de padrões, normas e regulamentos que dariam suporte ao trabalho colaborativo pelo BIM para toda a cadeia produtiva da construção civil. O trabalho foi dividido em etapas e foi conduzido junto com grupos da indústria, para conceder o tempo necessário para as empresas se prepararem pelo desenvolvimento de novas normas e treinamento. Estabeleceu-se que em 2016 todos os projetos e construções públicas deveriam ser desenvolvidos pelo processo totalmente colaborativo, modelo BIM tridimensional, com todas as informações, dados e documentação dos ativos em formato digital (UK GOVERNMENT, 2011).

Em 2016, o governo do Reino Unido lançou o Plano Estratégico Governamental para a Construção de 2016 até 2020, que estabelece a implantação do BIM nível 2 na cadeia produtiva da construção civil do país. Esse segundo nível requer uma maior colaboração entre todos os envolvidos no projeto, devendo eles trabalhar em conjunto desde o início, para criar a construção virtual do 
empreendimento, prevendo as melhores soluções para os projetos e testando os cenários antes da construção. Ele impõe a necessidade das empresas do setor desenvolverem todas as habilidades, capacitação e terem experiências com o BIM. Nesse momento, em conjunto com a indústria, o governo desenvolverá padrões regras e normas digitais para dar suporte à implantação do segundo nível do BIM na empresa, assim como prevê diversas outras frentes no seu plano de ação detalhado para garantir a adoção do método em nível nacional (UK GOVERNMENT, 2016).

O Brasil é um país que ainda está em fase inicial de adoção do BIM (MCGRAW HILL CONSTRUCTION, 2014), então existem algumas iniciativas na cadeia produtiva da construção civil que estão sendo desenvolvidas para fomentar o conhecimento e incentivar a adoção e o uso. Os autores Kassem e Amorim (2015) desenvolveram uma pesquisa no Brasil e na União Europeia por solicitação do Ministério do Desenvolvimento, Indústria e Comércio Exterior - MDIC e do Ministério do Planejamento, Orçamento e Gestão - MPOG, com o intuito de desenvolver recomendações para difusão do BIM no Brasil, permitir o desenvolvimento de ações coordenadas entre o MDIC e o MPOG para fomentar o BIM no país e identificar uma agenda gradual para tornar o BIM mandatório nos projetos e obras do Governo Federal.

Uma das sugestões ao fim da pesquisa foi que deveria ser obrigatória a adoção do BIM a partir de 2018 para todos os projetos financiados pelo Governo Federal. Esses usos deveriam ser incorporados da concepção até a operação do empreendimento e desenvolvido pelo trabalho colaborativo em um mesmo modelo. Foi verificado que a data dessa sugestão não foi cumprida, porém já existem esforços nesse caminho, que serão abordados nesta seção.

Para viabilizar essas obrigatoriedades, outra proposta foi a criação de um comitê de direção técnica para desenvolver todos os padrões, protocolos e diretrizes necessárias para guiar as empresas contratadas. Também evidenciaram a importância de atualizarem os métodos de projeto, orçamento e controle dos serviços que estão desatualizados desde 1997 (Portaria 2296), prevendo os padrões pré-BIM. Ainda propuseram o desenvolvimento de um Grupo de Trabalho, chamado de GT-BIM Brasil formado por líderes e, a partir disso, a criação de três comitês: Comitê de Direção Técnica, Comitê de Direção de Educação e Treinamento e o Comitê de Direção de Engajamento, com responsabilidades 
distintas. Esses comitês ficariam responsáveis pelo desenvolvimento dos protocolos, guias e normas necessários para a implantação do BIM, pelas ações de engajamento da indústria com o BIM, por gerarem infraestrutura e tecnologia para a aquisição publica de projetos em BIM, desenvolvimento de plano de ação para o aprendizado em BIM dos futuros profissionais e preverem incentivos fiscais para a adoção do BIM nas organizações.

No Brasil foi criada em 2009 uma comissão para o desenvolvimento de normas BIM, devido a uma iniciativa do MDIC. Em 2010, a Comissão de Estudo Especial de Modelagem de Informação da Construção, a ABNT/CEE-134 publicou a primeira norma que especifica as instruções e os procedimentos para o desenvolvimento de sistemas internacionais de classificação das informações da construção. A primeira norma foi basicamente a tradução da norma internacional ISO 12006-2 e recebeu o nome de ABNT NBR ISO 12006-2:2010 Construção de edificação - Organização de informação da construção - Parte 2: Estrutura para classificação de informação (CATELANI; SANTOS, 2016).

Os autores ainda explicam que para se trabalhar com o BIM é crucial que as informações sejam padronizadas para viabilizar o trabalho colaborativo. Em vista disso e baseado no sistema internacional Omni-Class ${ }^{\mathrm{TM}}$, essa comissão iniciou na sequência o desenvolvimento de um sistema de classificação para a construção brasileira. Esses esforços deram origem à ABNT NBR 15965, que consiste em um sistema de classificação que padronizam nacionalmente as informações da construção e são compatíveis internacionalmente. Composta por 13 tabelas, conforme se pode verificar na Figura 6, elas foram baseadas nas 15 tabelas da Omni-Class ${ }^{\mathrm{TM}}$, porém foram adaptadas à realidade brasileira. A finalidade dessas classificações pode ser para criar Estruturas Analíticas de Projetos - EAPs padronizadas capazes de serem lidas e entendidas por softwares, além de mais facilmente pelos profissionais (CATELANI; SANTOS, 2016).

A CBIC (2016f) explica que nessas tabelas, os termos da indústria da construção civil estão agrupados e codificados para que a comunicação fique compreensível e padronizada para todos os agentes do setor e para o entendimento dos softwares. As tabelas são referentes aos elementos, produtos, modelos de edificações, tipos de ambientes, serviços, materiais, disciplinas, entre outras informações. Com base nelas será possível definir todos os itens da construção civil. 
Figura 6 - Tabelas da ABNT NBR 15965

\begin{tabular}{|c|c|c|}
\hline Tema & Assunto & Tabela \\
\hline \multirow{2}{*}{ Caracteristicas dos objetos } & Materiais & $0 \mathrm{M}$ \\
\hline & Propriedades & $\mathrm{OP}$ \\
\hline \multirow{3}{*}{ Processos } & Fases & $1 F$ \\
\hline & Serviços & $1 S$ \\
\hline & Disciplinas & $1 \mathrm{D}$ \\
\hline \multirow{3}{*}{ Recursos } & Funções & $2 \mathrm{~N}$ \\
\hline & Equipamentos & $2 Q$ \\
\hline & Componentes & $2 \mathrm{C}$ \\
\hline \multirow{2}{*}{ Resultados da construção } & Elementos & $3 \mathrm{E}$ \\
\hline & Construção & $3 R$ \\
\hline \multirow{2}{*}{ Unidades e espaços da construção } & Unidades & $4 U$ \\
\hline & Espaços & $4 \mathrm{~A}$ \\
\hline Informação da construção & Informação & $5 l$ \\
\hline
\end{tabular}

Fonte: Catelani e Santos (2016)

Para auxiliar a elaboração da norma ABNT NBR 15965, foi criado o Grupo de Trabalho de Componentes BIM para a ABNT/CEE-134 em 2012, com o objetivo de desenvolver instruções e orientações para a constituição de componentes BIM. Até o momento foram publicadas as partes um em 2011, dois em 2012, três em 2014 e sete em 2015, sendo que as outras partes estão em desenvolvimento. (CATELANI; SANTOS, 2016). A coletânea de normas técnicas sobre a aplicação do BIM deverá ser comprada no site da ABNT (ABNT, 2017).

Kassem e Amorim (2015) sugeriram também a criação de uma organização brasileira semelhante ao "buildingSMART" com o objetivo de desenvolver a expertise em padrões abertos. Indicaram a necessidade de finalizar as normas ABNT para a classificação e identificação de objetos de uma biblioteca BIM. Similarmente evidenciaram a carência de normas que especifiquem as orientações para conteúdo gráfico e não gráfico. Além disso, o desenvolvimento de um documento que ateste as obrigações, direitos e responsabilidades de propriedade intelectual referente ao modelo é fundamental na opinião dos autores, sendo que esse documento e outros protocolos BIM deverão fazer parte de formas tradicionais de contratos. 
Os autores evidenciaram a necessidade de realizarem a capacitação da cadeia produtiva em relação ao BIM e propuseram como alternativas focar no ensino superior em nível federal e no treinamento de profissionais. Isso se daria pela redução de impostos, incentivo ao treinamento dos profissionais existentes hoje na indústria da construção, contratação das consultorias de implantação do BIM e aquisição das ferramentas BIM. Após a criação dos padrões e protocolos, deverá ser desenvolvida uma especificação técnica de um sistema online de colaboração em BIM no Brasil. Eles ainda citam a criação de editais para financiamento de pesquisas sobre o método (KASSEM; AMORIM, 2015).

O Comitê de Tecnologia e Qualidade do SindusConSP - CTQ, responsável pelas ações de tecnologia e qualidade setoriais, promove desde 2010 o Seminário Internacional BIM. que teve a sua oitava edição em outubro de 2017. O evento aborda o BIM como uma inovação disruptiva e trata sobre a revolução digital e os impactos na construção civil. Nesses eventos são realizados diversos debates com os líderes de empresas do mercado referente às estratégias para a implantação do BIM e são compartilhadas experiências práticas e lições aprendidas. Edições anteriores abordaram temas como: o Desenvolvimento Integrado de Empreendimentos (IPD) públicos e privados, a adoção do BIM por instituições públicas, o BIM como ferramenta de produtividade e a redução de riscos na crise, Lean Construction e BIM, dentre outros assuntos. Ademais, foi criado o Prêmio de Excelência BIM do SindusCon-SP, no qual os seus vencedores são reconhecidos durantes esses seminários. O prêmio foi criado com o objetivo de incentivar a adoção do BIM na cadeia produtiva da construção civil e está na sua segunda edição. (SINDUSCONSP, 2017; SINDUSCONSP, 2016; SINDUSCONSP, 2015; CTE, 2014)

Os outros Sindicatos da Indústria da Construção do país receberam os Workshops de implementação do BIM promovidos pela CBIC e pelo SENAI Nacional. Essas são iniciativas para disseminarem o BIM na cadeia produtiva da Construção Civil. Foi realizado em Manaus o quarto Workshop de Implementação do BIM na cadeia produtiva da construção, sediado pelo Sinduscon-AM, em parceria com a Comissão de Materiais, Tecnologia, Qualidade e Produtividade (COMAT) e a CBIC. Durante o evento, a CBIC indicou que o conhecimento sobre o BIM deve ser democratizado e propôs que isso deve ser feito por intermédio do oferecimento de subsídio à implantação do método na cadeia do segmento. Durante o evento, 
alguns líderes de empresas do mercado expuseram os seus cases de sucesso e palestraram referente às vantagens e possibilidades com o BIM.

Foi apresentada também, nesse momento, a "Coletânea Implementação do BIM para Construtoras e Incorporadoras" desenvolvida pela CBIC e pelo Senai Nacional (CBIC, 2017a). Além de Manaus, o CBIC e o SENAI promoveram esse mesmo workshop em Belo Horizonte, Recife, Fortaleza, Distrito Federal, São Luís e São Paulo. O evento foi realizado pelos respectivos Sinduscons e possuía agenda para passar em 10 cidades (CNI, 2017).

Em uma reunião em 2014, a ABRAMAT - Associação Brasileira da Indústria de Materiais de Construção - expressou a intenção de iniciar um processo para a produção de componentes digitais para bibliotecas BIM pela motivação dos seus membros para tal fim. O SENAI Nacional indicou que possui interesse no desenvolvimento de profissionais BIM para a Indústria AEC. A grande importância da motivação para as empresas adotarem o BIM pelos incentivos fiscais foi destacada pela AsBEA - Associação Brasileira Escritórios Arquitetura (KASSEM; AMORIM, 2015).

A CBIC, a COMAT e o SENAI Nacional se juntaram para promover o BIM na indústria AEC e, com isso, surgiu o projeto "Disseminação do BIM", liderado pelo empresário do setor, Paulo Sanchez, que indica que o BIM só começou a ser introduzido nas construções brasileiras em 2010. Esse projeto deu origem à cartilha "10 motivos para evoluir com o BIM" e à coletânea "Implantação BIM para Construtoras e Incorporadoras", disponíveis gratuitamente no site da CBIC. A FDE realizou uma audiência pública sobre a implantação do BIM em construções escolares e indicou a sua exigência nas próximas licitações. Eles ainda comentaram que na época já possuíam dois edifícios modelados, estavam com as equipes internas em processo de capacitação e desenvolvendo manuais BIM (SINDUSCONJP, 2016).

Em junho de 2017, o Governo Federal, pensando no desenvolvimento de uma estratégia para ajudar na disseminação e na adoção do BIM na cadeia produtiva da Construção Civil, criou o CE-BIM. Esse comitê tem o objetivo de promover a transformação digital da construção e as mudanças necessárias para garantir um ambiente adequado para o uso do BIM nacionalmente. Esse grupo é composto por representantes do MDIC, Ministério do Planejamento, Desenvolvimento e Gestão, do MCTIC - Ministério da Ciência, Tecnologia, 
Inovações e Comunicações, do Ministério das Cidades, da Casa Civil da Presidência da República, do Ministério da Defesa e Secretaria Especial do Programa de Parcerias de Investimentos da Secretaria Geral da Presidência da República. Além disso, foi criado o Grupo de Apoio Técnico (GAT-BIM) para apoio técnico ao CE-BIM, além de seis grupos para tratarem de temas específicos: Regulamentação e Normalização, Infraestrutura Tecnológica, Plataforma BIM, Compras Governamentais, Capacitação de Recursos Humanos e Comunicação (MDIC, 2018b).

Em março de 2018 foi realizado o evento "BIM: Oportunidade para inovar a indústria da construção e aumentar a transparência das compras públicas", em Brasília, pelo CBIC, SENAI Nacional e o CE-BIM. Apesar de ter sido um evento fechado ao público, tendo sido convidados apenas os representantes do governo, de órgãos de controle e da construção civil, ele foi transmitido ao vivo pelo Facebook da CBIC Brasil (CBIC, 2018a). Ele foi dividido em três painéis de debate: o primeiro teve o tema "Educação \& Capacitação" e contou com a palestra de um autor importante, Bilal Succar, e com a apresentação de um case de sucesso pelo Exército brasileiro. O segundo painel foi referente à "Implementação na indústria da construção", com as apresentações de cases de sucesso pela Sinco Engenharia e pela Itaúba Incorporações e Construções. O debate final foi pertinente às diferentes estratégias que estão sendo adotadas para implantar os processos BIM em diferentes empresas, visto que não existe apenas uma maneira de fazer isso. As experiências compartilhadas foram da FDE, da Companhia Paulista de Trens Metropolitanos (CPTM), do Governo de Santa Catarina e do Metrô SP (CBIC, 2018a).

A CBIC (2018a) cita que o presidente da COMAT, Dionyzio Klavdianos, destacou que o objetivo do evento foi salientar a importância da parceria entre o poder público e o setor privado para a adoção do BIM na cadeia da construção brasileira. A CBIC realizou, durante o ano de 2017, workshops em 14 cidades do país, com o intuito de disseminar o conhecimento sobre o BIM e democratizá-lo, apoiando o governo federal com o objetivo de demandar gradualmente que as novas contratações do setor público passassem a exigir o BIM.

Após esse evento, ocorreu em maio o 90 ENIC - Encontro Nacional da Indústria da Construção, também realizado pelo CBIC e pelo SENAI Nacional, com o tema "Inovar e crescer, construindo um país melhor". Nesse momento houve o 
marco da assinatura do decreto que cria a Estratégia Nacional para a Disseminação do Building Information Modeling, pelo Presidente da República, Michel Temer. O presidente da CBIC, José Carlos Martins, ressaltou a importância da indução do uso do BIM no mercado pelo Governo Federal, visto que ele é reconhecido como o grande cliente. As metas do decreto são de reduzir os custos da construção em 9,7\%, aumentar a produtividade das empresas em 10\% e elevar em 10 vezes a adoção do BIM no país em 10 anos. Caso esses objetivos sejam atingidos, a perspectiva de crescimento é de $28,9 \%$ no PIB da indústria da construção. (CBIC, 2018b)

Durante o evento, essa política nacional de disseminação ainda foi debatida pela COMAT, que enfatizou os benefícios da adoção do BIM nas obras públicas, como a melhora na qualidade das obras, menor incidência de erros, a ênfase no planejamento, a redução de desperdícios, a maior transparência nas contas públicas, a maior confiabilidade nas estimativas de custos e os cumprimentos dos prazos. (CBIC, 2018c)

A Estratégia Nacional de Disseminação do Building Information Modelling (BIMBR) foi então lançada em 2018 pelo governo federal, com o objetivo de desenvolver a transformação digital da indústria da construção brasileira. Desenvolvida pelo CE-BIM com o apoio do GAT-BIM, explorando assuntos relacionados à capacitação da cadeia produtiva, padronização e regulamentação, comunicação entre os agentes, desenvolvimento da infraestrutura tecnológica, uma plataforma BIM e as compras governamentais, conforme Figura 7. O objetivo estabelecido por essa estratégia é o de estruturar a adoção do BIM no setor público brasileiro, estimular a capacitação, desenvolver guias e protocolos para a adoção do BIM nas empresas, desenvolver uma Plataforma e uma Biblioteca Nacional BIM, criar condições para o investimento no método e estabelecer os requisitos para as contratações públicas dos projetos ou obras em BIM (MDIC, 2018c). 


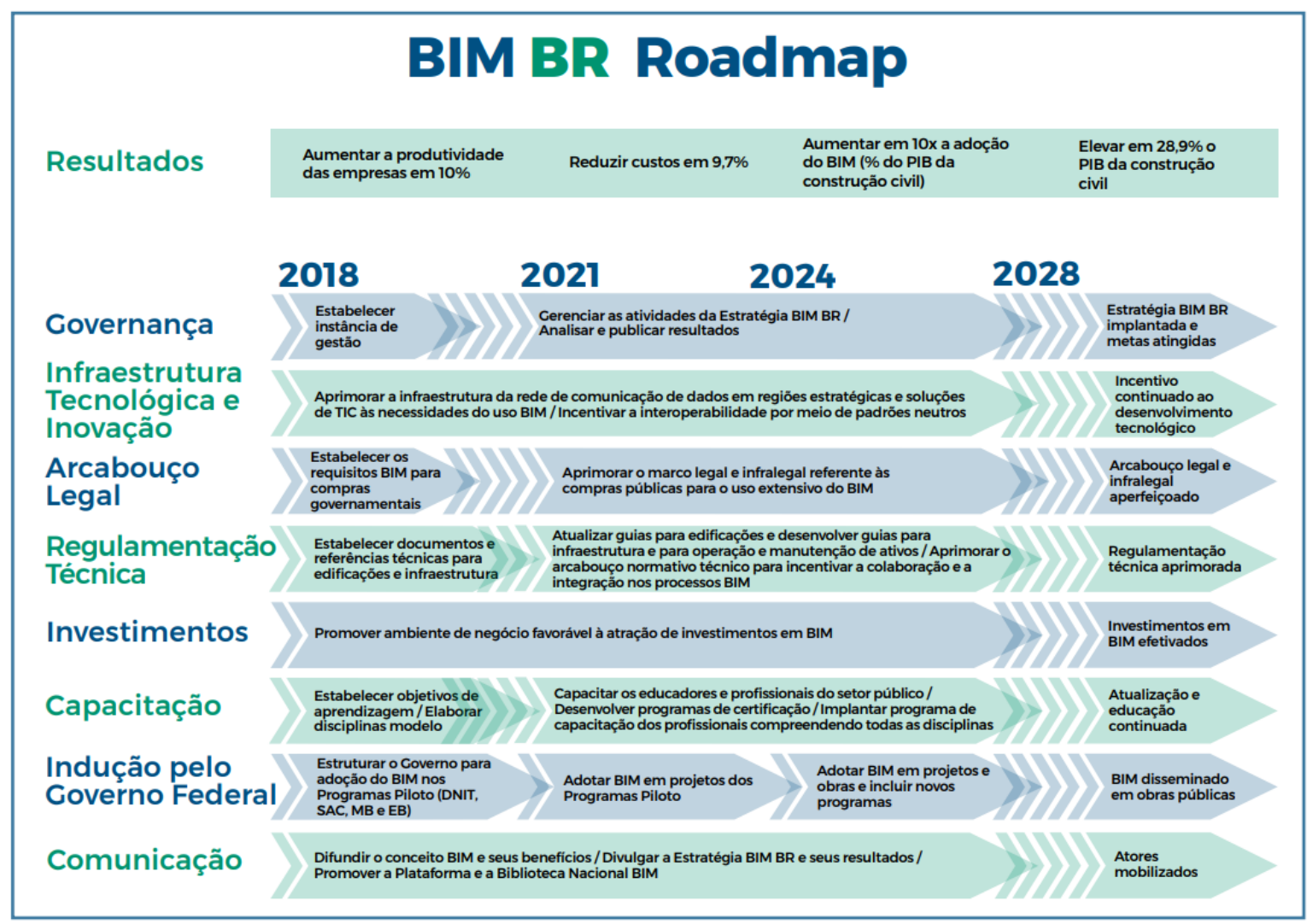

Fonte: MDIC (2018c)

Em 2 de abril de 2020 foi estabelecido o decreto $\mathrm{n}-10.306$ que oficializa a política setorial determinada em agosto de 2018, trazendo mais segurança para a continuidade da maturidade BIM no país. Esse decreto institui que os órgãos e as entidades da administração pública federal deverão utilizar o BIM diretamente ou indiretamente em obras e serviços de engenharia (PRESIDÊNCIA DA REPÚBLICA, 2020).

\subsection{A ImPLANTAÇÃo de INOVAÇões E A REJEIÇÃo À MudANÇA}

De acordo com Cândido e Abreu (2002), as organizações estão constantemente se atualizando e, com isso, as mudanças no ambiente organizacional são frequentes. Esse fenômeno afeta diretamente as pessoas envolvidas e o impacto nas mesmas sempre deve ser levado em consideração em qualquer processo de mudança, pois, segundo o autor, as organizações são vistas como um conjunto de indivíduos e grupos que estão constantemente envolvidos em 
relações internas e externas. O processo de mudança dentro de uma organização aumenta a incerteza e a insegurança dos profissionais. Por esse motivo, o modelo adotado pelas organizações é aquele no qual a empresa representa um conjunto de processos que devem estar em constante modificação e avaliação, porém, é necessário desenvolver estratégias para que essas mudanças sejam planejadas corretamente.

Essas transformações são inevitáveis para preservar as vantagens competitivas e gerar maior eficiência empresarial, principalmente relacionada à tecnologia. Essas inovações comumente resultam em redução de custos, desenvolvimento de novos produtos e melhorias nos processos de trabalho. Para adotar novas tecnologias e métodos de trabalho, a organização precisa passar por um processo contínuo, que consiste em diversas etapas, que se inicia no planejamento, no qual devem ser antecipados os problemas e as necessidades que serão causadas por aquela mudança, devem ser definidos previamente os critérios e estratégias para a adoção das inovações e levantadas as diversas variáveis envolvidas e as interações entre as mesmas (CÂNDIDO; ABREU, 2002).

Para Silva e Gil (2013), a inovação está associada e pode ser aperfeiçoada pela gestão de projetos, com base nos métodos e orientações do Project Management Institute (PMI) e do Project Management Body Of Knowledge (PMBOK). Eles definem a inovação em processos como a melhoria de um processo existente pelos softwares, técnicas e equipamentos para obter benefícios. Para os autores, quando uma inovação metodológica transforma o relacionamento entre fornecedores e clientes, traz-se transformações para o mercado, melhorias para o produto pelas características inéditas, dando, assim, origem a novos produtos. Essa é uma inovação radical.

Para acelerar e melhorar os resultados da implantação de uma inovação é necessário traçar uma estratégia de implantação baseada no tempo que se quer alcançar tal feito, ter suporte da alta gerência, contratar ou designar pessoas na alta hierarquia comprometidas, especificamente com o projeto, coleta de conhecimento externo, planejamento do processo com qualidade antes de iniciar e administrar e controlar o projeto de implantação (CORAL; OGLIARI; ABREU, 2008 apud SILVA; GIL, 2013). 
Uma inovação precisa ser introduzida às empresas por um projeto, sendo o ciclo de vida do mesmo definido por Silva e Gil (2013) da criação da ideia até a implantação concluída. Além disso, eles destacam a importância em criar um ambiente organizacional voltado a projetos, porque apesar de ser um desafio, isso diminui a rejeição à mudança dos profissionais da empresa e a disposição dos profissionais para colaborarem com a implantação de inovações na empresa.

Os autores Cândido e Abreu (2002) indicam que os sistemas de inovação envolvem aspectos tecnológicos e sociais, portanto, destaca-se a importância da busca pela sinergia entre os profissionais e as empresas. A partir do contexto social do problema que a inovação propõe resolver é possível fortalecer o engajamento dos participantes. Além disso, é fundamental a definição clara dos papeis de cada profissional, da motivação dos colaboradores pelo clima organizacional e recompensas.

Segundo Cândido e Abreu (2002), o primeiro passo seria a definição das variáveis do processo, referentes aos valores sociais, os papéis, as formas de poder e os relacionamentos interpessoais, que influenciam diretamente o processo. Seguido, tem-se a análise do ambiente externo e do ambiente interno à organização, para a identificação das necessidades dela, para o embasamento das tomadas de decisão e para o desenvolvimento das estratégias. Como consequência dessa etapa, deverá ser desenvolvida uma busca das causas raízes dos problemas, com o objetivo de identificar também as possíveis soluções para as necessidades da empresa. Em seguida, define-se uma estratégia para a implementação da solução ideal identificada, desenvolvimento da implementação e avaliação contínua da resolução, até que surjam novas necessidades e problemas e que seja necessária a realização de outra inovação.

De acordo com Cândido e Abreu (2002), a rejeição à mudança pelos colaboradores da empresa é o maior obstáculo frente às novas implantações nas empresas, visto que as suas formas de percepção e a reação são diferentes, bem como os seus valores e culturas. Por isso, além da mudança da cultura organizacional que deve ocorrer, a empresa deve também auxiliar os colaboradores, utilizando-se de estratégias de resistência à mudança, para que eles consigam realizar a transformação individual frente à inovação. 
Kotter (1977 apud CÂNDIDO; ABREU, 2002) relata em seu método para lidar com a resistência às mudanças, que o ideal para aumentar o comprometimento dos colaboradores é iniciar pela instrução dos profissionais, seguido pela comunicação aberta, engajando e envolvendo a equipe no processo de inovação. Um retorno também relevante seria apoiar esses funcionários durante a implantação, negociar e realizar acordos para esse fim e, como últimos recursos, mas não tão eficaz, seria convencer os profissionais pela manipulação e imposição. Os autores Cândido e Abreu (2002) definem que as pessoas são o foco principal da implantação de inovações.

\subsection{A adoção do BIM}

O processo de adoção do BIM não possui um caminho único, variando de empresa para empresa, pois cada uma possui estruturas hierárquicas, burocracias e processos diferentes. Entretanto, muitos autores indicam as fases e ações macro a serem desenvolvidas, visando diminuir o impacto que essa mudança traz para o método de trabalho dos profissionais e para a organização da companhia. A adoção do BIM em qualquer empresa precisa ser um processo pensado, planejado e estruturado para que os benefícios do método sejam efetivamente alcançados, além dos objetivos de melhoria.

Eastman et al. (2014) evidencia a utilização do método BIM como forma de trabalho é mais do que aquisição de software, treinamento, atualização de hardware e mudança de um ambiente 2D para 3D. Sua adoção demanda mudanças em todo o processo de trabalho, portanto, essa questão precisa ser compreendida e o processo de adoção estruturado antes de qualquer implantação ser feita na empresa. Para começar essa adoção, cada organização terá que realizar modificações específicas. Contudo, os autores definem as alterações em geral aplicáveis para qualquer instituição nesse momento:

d) Designar responsabilidade a alta gerência pelo desenvolvimento de um plano de adoção do BIM que cubra todos os aspectos do negócio da empresa e como as mudanças propostas impactarão tanto nos parceiros externos e clientes;

e) Criar uma equipe interna de gerentes principais responsável pela implementação do plano, com orçamentos de custo, tempo e rendimento para guiar seu desempenho; 
f) Começar usando o sistema BIM em um ou dois empreendimentos menores (talvez até já terminados) em paralelo com a tecnologia existente e produzir documentos tradicionais a partir do modelo de construção. Isso ajudará a revelar onde há deficiências nos objetos da construção, em capacidades de produção, em vínculos com programas de análise, etc. também fornecerá oportunidades educacionais para os líderes;

g) Usar os resultados iniciais para educar e guiar a adoção contínua de software BIM e o treinamento adicional de pessoal. Manter os gerentes seniores informados do progresso, dos problemas, das percepções, etc;

h) Ampliar o uso do BIM para novos empreendimentos e começar a trabalhar com membros de fora da empresa em novas abordagens de colaboração que permitam fazer mais cedo a integração e o compartilhamento do conhecimento usando o modelo de construção;

i) Continuar a integrar as capacidades do BIM em todos os aspectos das funções da empresa e refletir esses novos processos de negócio em documentos contratuais com clientes e parceiros de negócios;

j) Replanejar periodicamente o processo de implementação do processo BIM para refletir os benefícios e problemas observados até então e estabelecer novas metas para desempenho, tempo e custo. Continuar a estender as mudanças facilitadas pelo BIM para novos locais e funções dentro da empresa (EASTMAN et al., 2014, p. 22; 23).

Os autores ainda citam que os proprietários e contratantes, como as agências governamentais, embora não tenham todo o conhecimento sobre BIM, devem adotar algumas medidas para garantirem que os seus projetos e obras sejam entregues em BIM pelos subcontratados, com toda a tecnologia, integração de dados e informações necessárias. Uma delas deve ocorrer durante a contratação de prestadores de serviços, havendo a possibilidade de modificar os requisitos solicitados para a contratação, indicando a exigência de conhecimentos e experiencia em BIM.

Outra medida seria a inclusão de critérios de pré-qualificação específicos relacionados a esse método, como, por exemplo, em licitações, sendo incluídos critérios no edital para os licitantes. Semelhante a essa medida, durante o processo de seleção, é possível realizar entrevistas com os candidatos a prestação de serviço e realizar perguntas referentes ao conhecimento dos profissionais e das suas experiências com o BIM. 
Eastman et al. (2014) indica que a mudança dos requisitos nas entregas é um fator fundamental para os proprietários ou para as empresas contratantes que se encontram no meio do processo, como é o caso das construtoras ou empresas públicas. Para garantir que o produto virá da maneira prevista é necessário alterar os contratos e a linguagem deles. Entretanto, para essa medida ser completamente eficaz, é essencial definir mudanças também no processo de entrega dos projetos. Isso inclui as alterações nos requisitos contratuais e licitatórios, a definição das aplicações BIM a serem utilizadas no projeto, a designação da mudança do formato da documentação a ser entregue: de papel para digital, da modificação da entrega do projeto: de 2D para 3D e, por fim, a significação dos tipos de informações que deverão conter no modelo. É importante estarem definidos, previamente, também quais são os usos que as informações do modelo terão posteriormente. Desse modo ficará mais claro para o prestador de serviço quais as informações cruciais a serem inseridas no modelo e qual é a sua relevância. A estrutura de organização das informações do modelo também deverá ser definida, uma vez que a facilidade da troca de informações, comunicação e documentação dependem dela.

São destacadas também a importância da preparação dos profissionais para a mudança que a adoção de um novo processo de trabalho e novas tecnologias requerem. Essa relevância diz respeito à transição intelectual inevitável durante a adoção do BIM, que impacta principalmente os profissionais sêniores das empresas, visto que já possuem suas formas de trabalho e experiências de décadas e, muitas vezes, com poucas ou sem alterações. Os maiores desafios para a adoção do BIM, que trará tantas transformações em todas as etapas e formas de trabalho, são de garantir que todos os profissionais compreendam os benefícios do novo método em implantação, entendam a importância da mudança e que isso faça sentido para eles e para suas rotinas.

Uma saída identificada pelos autores para garantir que os profissionais seniores das empresas estejam engajados e receptivos à mudança é colocá-los com pessoas experientes nas ferramentas BIM, para que eles visualizem os benefícios na prática. $O$ treinamento desses nas ferramentas acaba acontecendo concomitantemente com as experiências em conjunto. Por consequência, todo o conhecimento desse profissional será colocado em prática pela utilização das novas tecnologias e aos poucos também fará sentido a mudança do processo de trabalho. 
O treinamento dos profissionais é indispensável, no entanto, essa carga não deve ser muito pesada para evitar a sobrecarga nos mesmos. Dessa forma, Eastman et al. (2014) sugere que o ideal são os treinamentos semanais. Apesar dessas orientações, nenhum método é garantido e funciona de maneiras diferentes de uma empresa para a outra, todavia a mudança deve ser cultural dentro da organização, para que os profissionais percebam que a modificação acontecerá continuadamente e permanentemente.

Durante o processo de adoção ainda há a necessidade de definição de novos papeis para os profissionais, sendo que um deles deverá ser responsável pela integração dos sistemas, configuração das trocas de informações entre os softwares BIM internas e externas a organização, criação de bibliotecas e padrões. O outro diz respeito ao gerenciamento do modelo, enquanto uma pessoa está responsável pela criação de protocolos de controle e administração de versões. Esse profissional deverá focar no gerenciamento do conjunto de modelos integrados, garantindo a integridade dos modelos, evitando danos ao mesmo e realizando a manutenção dos dados. Esse responsável ainda tem a responsabilidade de garantir a consistência dos modelos, pela determinação das políticas de atribuições que cada editor possui nos modelos de cada uma das disciplinas, como, por exemplo, o projetista estrutural poderá editar o modelo de estruturas, mas só poderá visualizar o de arquitetura. (EASTMAN et al., 2014)

Para a CBIC (2016b), a adoção do BIM deve ser feita fundamentada em um plano formal de adoção, com pelo menos o mínimo de estruturação e totalmente documentado, sendo que durante a criação desse projeto de implantação é necessário definir os principais objetivos que a empresa possui com tal implantação, o que ela idealiza atingir e, então, deverá haver a definição do projeto-piloto para efetivar essa adoção. Como qualquer outro projeto, para esse também é crucial prever a gestão desse plano de adoção para garantir o sucesso e a efetividade de cada etapa. Por esse motivo, o autor sugere que a gestão siga as técnicas e boas práticas do PMI.

O plano BIM então deve ser formalmente desenvolvido, documentado e controlado pelas técnicas de gestão de projetos e deverá seguir dez etapas básicas, conforme a Figura 8. Tais fases podem não ser as únicas, mas são aquelas essenciais para toda adoção do método BIM. Todos os passos definidos pelo autor se referem à necessidade de realizar um planejamento minucioso da adoção antes 
de partir para a parte prática, na qual estarão desenhados todos os detalhes que a equipe deverá seguir ao longo do fluxo de trabalho, devendo prever o monitoramento, atualização e revisão do mesmo regularmente. (CBIC, 2016b)

Figura 8 - Principais etapas para um projeto de adoção do BIM

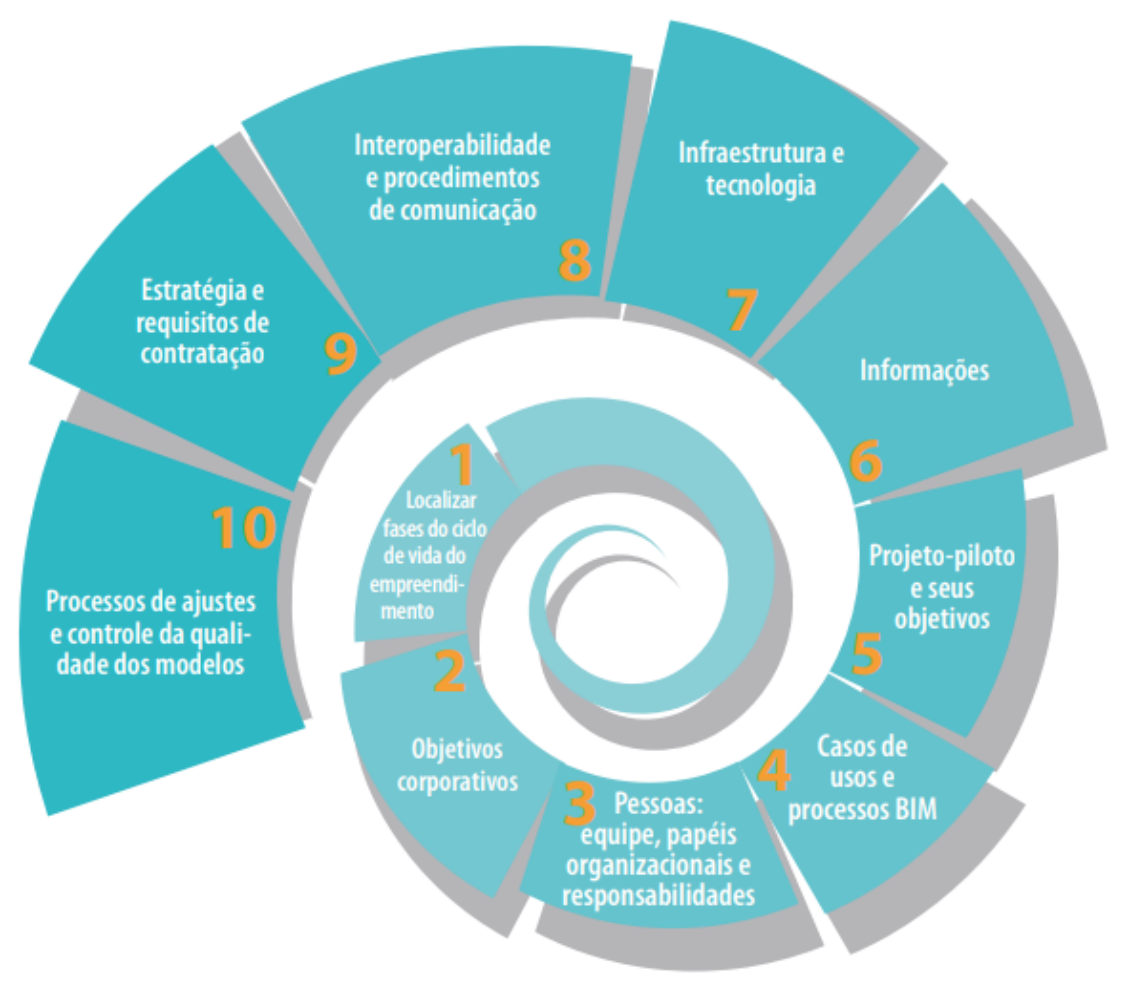

Fonte: CBIC (2016b)

A primeira atividade prevista para o desenvolvimento do Plano BIM é a definição da localização em que a empresa se encontra no ciclo de vida do empreendimento, conforme se pode verificar na Figura 9, pois isso servirá para fases posteriores, como a determinação de objetivos e processos. Nessa mesma figura é possível identificar que, por exemplo, uma empresa incorporadora focaria em todas as atividades relativas ao "pré-obra", portanto, ela teria a necessidade de priorizar o desenvolvimento dos modelos de projeto e análise, com os objetivos de coordenação e documentação do projeto, dentre outros fatores. Já uma construtora focaria na etapa de obra, na qual as suas necessidades seriam relativas ao modelo de construção e canteiro da obra, planejamento da execução, orçamentação e fabricação. 
Figura 9 - Ciclo de vida de um empreendimento

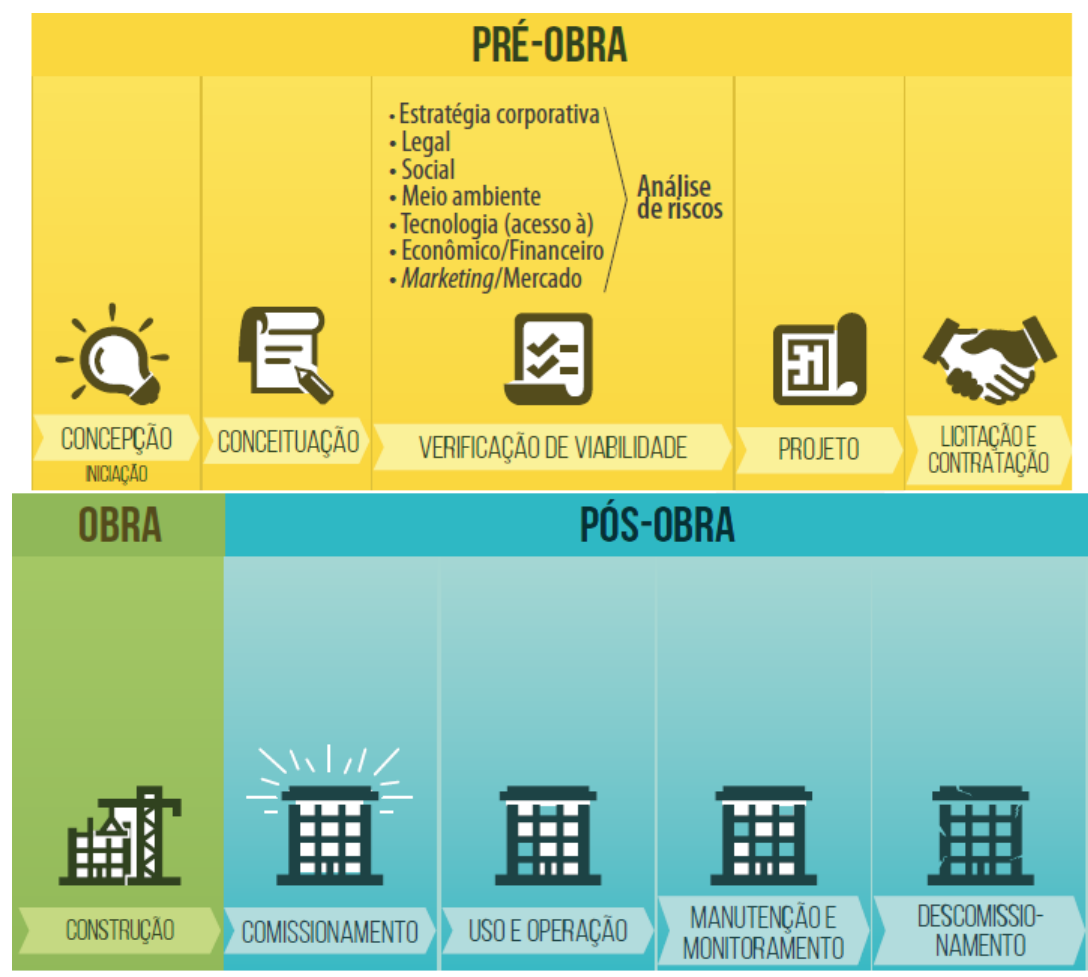

Fonte: CBIC (2016a)

A próxima etapa se refere à definição dos objetivos da implantação do BIM, que devem seguir a mesma linha de raciocínio dos objetivos estratégicos da corporação e visarem a melhoria nas atividades críticas da empresa e nos processos. Não há quantidade mínima ou máxima de objetivos, porém é recomendado que a maioria seja tangível, visto que há a necessidade de medir, posteriormente, se eles foram atingidos, além de compará-los com os índices da situação anterior à adoção. Os objetivos idealizados deverão estar diretamente ligados às atividades principais da empresa e fazerem relação com as capacidades do BIM. Para uma construtora, por exemplo, o objetivo pode ser "Aumentar a acurácia das estimativas iniciais de custos dos empreendimentos, reduzindo a margem de erro para uma média de 15\%".

Imediatamente deve ser realizada a definição dos profissionais da equipe que será responsável pela adoção do BIM, definir os papeis organizacionais das mesmas e as suas responsabilidades. Isso é fundamental para garantir que as atividades a serem desenvolvidas sejam endereçadas e possuam um "dono". Para isso, o autor sugere a definição de um gerente BIM e a capacitação do mesmo, devendo ficar responsável por liderar e gerenciar o Plano BIM de adoção, garantir 
que o treinamento da equipe seja completo e eficaz, realizar as reuniões periódicas do processo de adoção e do desenvolvimento do projeto-piloto, gerenciar a comunicação e a troca de informações, solucionar os conflitos, bem como gerenciar, manter e controlar a qualidade dos modelos das diferentes disciplinas.

Ainda de acordo com CBIC (2016b), esse profissional será o ponto focal sobre o BIM dentro da companhia e ele pode ser contratado ou ser alguém que já existe na empresa, mas, para isso, será necessário capacitar essa pessoa pelos treinamentos com consultoria especializada. O treinamento do gerente BIM e do restante da equipe é fundamental e a sua eficiência é fator chave para garantir o sucesso da implementação do BIM. Com a equipe e as responsabilidades definidas, para o controle e o gerenciamento dessa etapa do projeto, é importante desenvolver o documento que registre essas definições de papeis e responsáveis.

Em seguida, é prevista a definição dos potenciais usos e mapeamentos dos processos BIM. Tais usos são identificados na Figura 4 da seção 3.2.3 deste trabalho, que contém os 25 usos mapeados e documentados pela Penn State University e, subsequentemente, analisar os processos já existentes e ajustá-los para que os objetivos e os usos sejam neles implementados. Para realizar a definição dos usos, a Figura 9 também desenvolvida pela Penn State Univesity, traz uma matriz com diversas variáveis para facilitar a seleção dos usos a serem realizados na empresa.

$\mathrm{Na}$ primeira coluna deverão constar os usos potenciais de implementação identificados; em seguida deverá haver uma coluna evidenciando o valor que aquele uso trará para os projetos da empresa; então precisará haver uma coluna na qual os responsáveis por desenvolverem esse uso estarão listados; seguidamente será demonstrado o valor que esse uso representará para cada uma das partes responsáveis; a quinta coluna se refere ao nível de capacitação em escala de 1 a 3, para os três tipos de capacitação: "Recursos", "Competências" e "Experiências", adicionalmente haverá um campo ao lado para a definição dos recursos adicionais ou competências necessárias para a adoção de cada parte responsável. 
Figura 10 - Tabela de seleção dos usos BIM adaptada de CIC (2010)

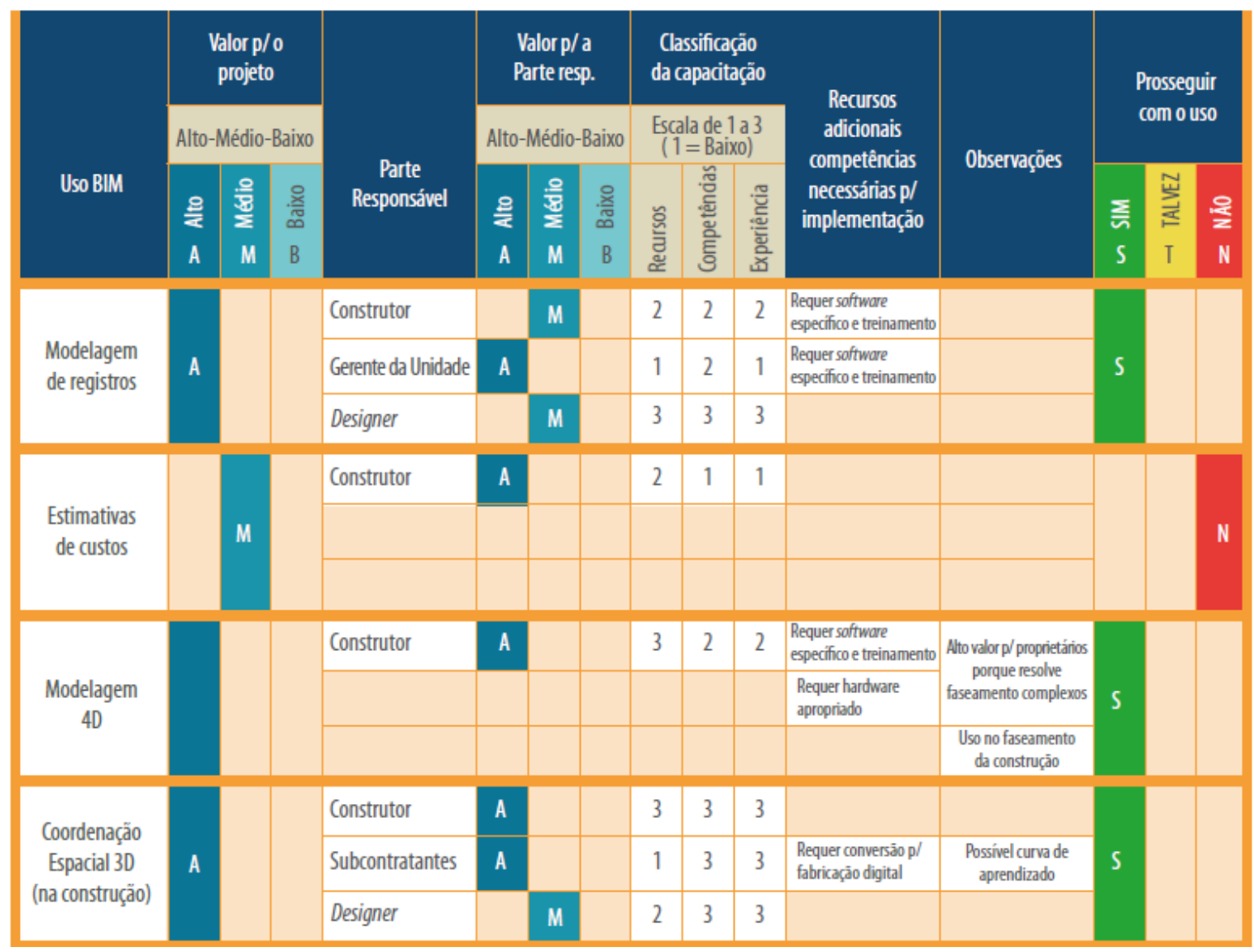

Fonte: CBIC (2016b)

Ainda deverá constar uma coluna para as observações e, por fim, uma de decisão se a empresa prosseguirá ou não com a implantação daquele uso. Para o preenchimento da tabela deverá ser inserido apenas os potenciais usos para aquela organização especifica, identificados na listagem dos 25 usos. Nesse momento deve ser considerada a aderência de cada um deles com os objetivos definidos para a adoção do BIM. A parte responsável se refere ao profissional ou profissionais que estarão diretamente envolvidos com o uso identificado.

A parte de capacitação se refere aquilo que os profissionais ou a empresa já possuem no momento do preenchimento, portanto "Recursos" competem às questões relacionadas à equipe BIM (recursos humanos), treinamento, software, hardware, etc.; As "Competências" se remetem ao know-how daquele profissional para implementar aquele uso de BIM com sucesso; e "Experiências" se referem expressamente à experiência que esse profissional possua com esse uso, se ele já desenvolveu algum projeto em BIM com esse uso, sendo que a existência de experiência prévia favorece o sucesso da adoção. A definição do valor gerado em 
cada uso deverá ser avaliada pela equipe de implantação do BIM, tendo em vista os possíveis ganhos e riscos que aquele determinado uso representa. Por fim, a decisão de implementação de cada um dos usos deve ser baseada nas respostas e nas características da empresa, na consideração da equipe de implantação e na avaliação dos custos e benefícios.

$\mathrm{Na}$ etapa cinco deverá ser escolhido um projeto-piloto para começar a implementação prática do BIM na empresa, sendo necessário fazer uma análise minuciosa antes da sua definição, levando em consideração que o projeto escolhido deverá representar um projeto típico da empresa e não ser nem muito simples nem muito complexo. Para esse projeto-piloto deverão ser definidos novamente os objetivos, que não precisam ser iguais aos de adoção do BIM na empresa, mas devem estar em concordância com eles. Ademais, nesse momento devem ser definidos os objetivos específicos, focados no aprendizado e capacitação, e delineados os processos correspondentes que deverão sofrer alterações. A partir dessa primeira experiência e dos seus objetivos, deverão ser documentados o escopo desse projeto, a lista de requisitos, a estrutura analítica do projeto, o plano de gerenciamento, o cronograma, as atividades, o seu sequenciamento, os recursos necessários para realizá-las e as suas durações, conforme recomendações do PMI.

Em seguida, as informações críticas para cada um dos processos identificados na etapa anterior deverão ser mapeadas, podendo ser trocadas durante a realização de cada processo internamente ou compartilhada por diferentes fases e participantes. A clareza das informações enviadas e o entendimento correto das mesmas são fatores cruciais para garantirem o sucesso da implantação do BIM e esses procedimentos devem ser sempre documentados. Nessa etapa também deverá ser criada uma planilha contendo todas as informações importantes que deverão ser trocadas durante todo o projeto-piloto e mapeando os seus autores e receptores, conforme a Figura 11. 
Figura 11 - Planilha de troca de informações adaptada de CIC (2010)

PLANILHA DE TROCA DE INFORMACÕ̃ES:

\begin{tabular}{|c|c|c|c|c|c|c|c|c|c|c|c|c|c|c|}
\hline Nivel & \multicolumn{3}{|c|}{ Informaçōes } & \multicolumn{2}{|c|}{ Sigla } & \multicolumn{4}{|c|}{ Parte Responsável } & & & & & \\
\hline \multirow[b]{2}{*}{ A } & \multirow{2}{*}{\multicolumn{3}{|c|}{$\begin{array}{l}\text { Tamanho e localização precisos, } \\
\text { incluindo materiais e objetos } \\
\text { paramétricos }\end{array}$}} & \multirow{2}{*}{\multicolumn{2}{|c|}{ ARQ }} & \multicolumn{4}{|c|}{ Arquiteto } & & & & & \\
\hline & & & & & & \multicolumn{3}{|c|}{ Construtor } & & & & & & \\
\hline \multirow{3}{*}{ B } & \multirow{3}{*}{\multicolumn{3}{|c|}{$\begin{array}{l}\text { Tamanho e localização genéricos, } \\
\text { incluindo dados paramétricos }\end{array}$}} & \multicolumn{2}{|c|}{ EC } & \multicolumn{4}{|c|}{ Engenheiro Civil } & \multicolumn{5}{|c|}{ PS $=$ Projeto Esquemático } \\
\hline & & & & \multicolumn{2}{|c|}{ GM } & \multicolumn{4}{|c|}{ Gerente de Manutençäo } & \multicolumn{5}{|c|}{$\mathrm{AP}=$ Anteprojeto } \\
\hline & & & & \multicolumn{2}{|c|}{ EI } & \multicolumn{4}{|c|}{ Engenheiro de instalaçäo } & \multirow{2}{*}{\multicolumn{5}{|c|}{$\mathbf{P E}=$ Projeto Executivo }} \\
\hline \multirow[t]{2}{*}{ c } & \multirow{2}{*}{\multicolumn{2}{|c|}{$\begin{array}{l}\text { Tamanho e localizaçäo } \\
\text { esquemáticos }\end{array}$}} & & \multicolumn{2}{|c|}{ EE } & \multicolumn{4}{|c|}{ Engenheiro de Estruturas } & & & & & \\
\hline & & & & G & & Gerer & nte de Co & mpras & & \multicolumn{5}{|c|}{ CO = Construçäo } \\
\hline \multirow{2}{*}{\multicolumn{3}{|c|}{$\begin{array}{l}\text { Nome da troca de informaçäo } \\
\text { Fase da Troca (PE, AP, PE, CO) }\end{array}$}} & Mode & lagemo & le Registro & & anejame & nto 4D & Coord & lenação & Espacial 3D & & rojeto A & Itoral \\
\hline & & $P E,(0)$ & & CO & & & PE & & & $\mathrm{PL}$ & & & PE & \\
\hline Recep & do Modelo & & & GN & & & CON & & & $\mathrm{CON}$ & & & Todo & \\
\hline Form: & le Arquivo $R_{e}$ & cebido & & & & & & & & & & & & \\
\hline Aplica & eversäo & & & & & & & & & & & & & \\
\hline Estrut & de divișão do & modelo & Info. & $\begin{array}{l}\text { Parte } \\
\text { Resp. }\end{array}$ & $\begin{array}{l}\text { IIformaçāo } \\
\text { Adicional }\end{array}$ & Info. & $\begin{array}{l}\text { Parte } \\
\text { Resp. }\end{array}$ & $\begin{array}{l}\text { Informaçāo } \\
\text { Adicional }\end{array}$ & Info. & $\begin{array}{l}\text { Parte } \\
\text { Resp. }\end{array}$ & $\begin{array}{l}\text { Informaç̧āo } \\
\text { Adicional }\end{array}$ & Info. & $\begin{array}{l}\text { Parte } \\
\text { Resp. }\end{array}$ & $\begin{array}{l}\text { Informaçāo } \\
\text { Adicional }\end{array}$ \\
\hline $\mathrm{A} \mid \mathbb{F}_{\mathrm{Fu}}^{\mathbb{N}}$ & $\begin{array}{l}\text { ESTRUTURA } \\
\text { zōes }\end{array}$ & & & & & & & & & & & & & \\
\hline & & $\begin{array}{l}\text { Estacas padronizadas } \\
\text { Estacas especiais } \\
\text { Laje radier }\end{array}$ & & & & & & & & & & & & \\
\hline & Zaldrame & & & & & & & & & & & & & \\
\hline & & \begin{tabular}{|l} 
Escavação de vigas \\
baldrame \\
Vigas baldrame
\end{tabular} & & & & & & & & & & & & \\
\hline $\bar{B}$ & MENTOS & & & & & & & & & & & & & \\
\hline & strutura & & & & & & & & & & & & & \\
\hline & & $\begin{array}{l}\text { Lajes do pavimentos } \\
\text { Laje de cobertura }\end{array}$ & & & & & & & & & & & & \\
\hline & & & & & & & & & & & & & & \\
\hline & & $\begin{array}{l}\text { Paredes externas } \\
\text { Janelas externas } \\
\text { Portas externas }\end{array}$ & & & & & & & & & & & & \\
\hline & & & & & & & & & & & & & & \\
\hline & & \begin{tabular}{|l|} 
Telhamento \\
Aberturas na cobertura
\end{tabular} & & & & & & & & & & & & \\
\hline $\bar{c}$ & & & & & & & & & & & & & & \\
\hline & uçāo internas & & & & & & & & & & & & & \\
\hline & & \begin{tabular}{|l} 
Divisiórias internas \\
Portas internas \\
Lajes radier
\end{tabular} & & & & & & & & & & & & \\
\hline & & & & & & & & & & & & & & \\
\hline & & Construção de escadas & & & & & & & & & & & & \\
\hline
\end{tabular}

Fonte: CBIC (2016b)

Após todas essas definições, é importante ainda definir as ferramentas tecnológicas que serão necessárias para dar suporte à implantação dos processos BIM, além da infraestrutura necessária. $O$ autor indica que isso só será possível após a definição de todos os projetos-pilotos delineados e desenhados, conforme os passos anteriores, pois as necessidades podem variar de um projeto para outro. Nesse momento deverá haver a escolha dos softwares e das versões que serão utilizadas. A partir disso deverão ser feitos os testes de interoperabilidade para garantir que haja a fluidez das informações, dos dados e dos processos de trabalho. A partir desses testes deverão ser identificados os formatos dos arquivos, para que haja interoperabilidade entre esses sistemas. 
O hardware também precisa ser definido para garantir a troca de informações eficiente e as especificações mínimas necessárias, devendo ser dimensionado para a aplicação que mais exigir a capacidade de processamento e de desempenho. Caso essa etapa não seja corretamente planejada, pode acarretar frustrações dos profissionais, perda de prazos, aumento de custos e perda de produtividade. Finalmente, as informações referentes ao banco de dados, templates, bibliotecas BIM, dentre outras, também precisarão ser definidas com o objetivo de padronizar as informações. Com toda a infraestrutura definida podem ser então desenvolvidos e documentadas as estimativas de custos dos projetos-pilotos, as aprovações de orçamento, o planejamento do gerenciamento dos riscos e a identificação deles.

A oitava etapa - Interoperabilidade e Procedimentos de Comunicação refere-se ao planejamento que deve ser feito pela equipe de implantação do BIM das trocas de informações dos projetos, pois devem ser previstas as informações cruciais de cada disciplinas que devem ser trocadas e os momentos-chave dessas mudanças durante o desenvolvimento dos projetos. A princípio deverão ser definidos quais são os componentes e as informações que serão necessárias ao longo de todo o desenvolvimento do projeto para alcançar todos os usos previstos. Também é importante prever apenas o nível de detalhamento realmente necessário para aquele projeto-piloto, para evitar sobrecarregar o modelo de informações que não serão utilizadas.

Durante o mapeamento dos processos BIM é possível identificar os momentos de potencial necessidade de troca de informações entre dois agentes envolvidos no processo. A partir dessa identificação deverá ser previsto e documentado no plano de implantação do BIM as datas de conclusão e a disponibilização dos entregáveis BIM planejados, bem como as informações que deverão ser transferidas. Essa etapa oito também prevê a definição da estrutura de divisão do projeto. O autor CBIC (2016b) orienta seguir a CSIUniformat, que se trata de um padrão de classificação de informações, ou a Norma ABNT NBR-15965, que ainda não foi completamente publicada.

Para idealizar a troca de informações efetiva na empresa, três tópicos deverão ser discutidos e documentados no projeto de adoção do BIM: o primeiro é referente aos receptores dos modelos BIM - todos eles deverão ser identificados e documentados - e que essas pessoas sigam os padrões de preenchimento das entradas de informações no modelo, bem como completem corretamente os 
formulários ou outras ferramentas que sirvam para documentar cada momento de troca de informações. O segundo é referente aos softwares e aplicativos citados na fase 7, na qual todos os que serão utilizados deverão estar documentados no Plano BIM. O último é referente às informações necessárias para cada uso, conforme descrito na fase 6 . Nesse momento, para a gestão da obra fluir corretamente, deverá ser desenvolvido o documento referente ao planejamento das comunicações.

Também é necessário prever a estratégia e os requisitos para a contratação, para que as expectativas sejam definidas previamente quanto à contratação dos fornecedores. A estratégia de contratação e o acompanhamento do que foi definido é uma etapa importante, a qual também prevê a necessidade de estabelecer o trabalho colaborativo e, como isso, deverá ser realizado entre os diferentes envolvidos no processo. Por esse motivo, a implantação do BIM nos projetos altera a maneira de contratar e medir o progresso do processo de trabalho. Deve ser definida claramente a divisão do trabalho interno da empresa e quais são as responsabilidades de cada um dos fornecedores, para então definir o escopo da implantação.

Nessa nona etapa, o autor ainda define o papel importante do gerente BIM, o responsável pelo projeto de adoção na empresa, que coordena todas as etapas e a colaboração entre os envolvidos no projeto. As organizações deverão planejar como realizarão as suas contratações, prevendo os métodos de cotação, contração e pagamento a serem utilizados, como serão feitos o desenvolvimento e o compartilhamento dos modelos e quais os papeis e as responsabilidades de cada um dos envolvidos, o nível de interoperabilidade e os formatos necessários para a troca de informações e os direitos de propriedade intelectual. Para as empresas contratadas, deve-se exigir alguns requisitos mínimos, como a qualificação BIM dos seus profissionais, qual é o fluxo de trabalho esperado por elas, as informações mínimas entregues em cada uma das etapas, o cronograma performado e o nível de qualidade exigido.

Na última etapa deverão ser definidos os métodos de controle de qualidade do produto esperado, como será realizada a revisão do modelo, quais serão os marcos de entrega, quantas e quando serão as reuniões de coordenação, quem serão os responsáveis por garantir a qualidade de cada projeto. Além disso, as boas práticas do PMI deverão ser seguidas nessa etapa para garantir o controle efetivo 
do projeto, pela integração dos envolvidos no controle das mudanças e no monitoramento dos trabalhos, garantir a assertividade do escopo do projeto de acordo com as expectativas, possibilitar o cumprimento do prazo controlando o executado e o cronograma, analisando os custos, a qualidade e os riscos.

\subsection{Gestão de Projetos}

A CBIC (2016b) define que a gestão do projeto de adoção do BIM nas empresas é crucial durante as dez etapas e após para garantir a correta implantação. Baseado nas informações do PMI, ele define quais são as atividades a ser desenvolvidas em cada uma das disciplinas: integração, escopo, tempo, custo, qualidade, pessoas, comunicação, risco e aquisição; e em cada uma das fases de implantação: iniciação, planejamento, execução, controle e encerramento. Essas fases são definidas pelo PMI (2013) como os Grupos de Processos de Gerenciamento de projetos (Figura 12), que interagem entre si e em muitos momentos se sobrepõem durante o projeto, conforme a Figura 13.

Figura 12 - Grupos de processos de gerenciamento de projetos

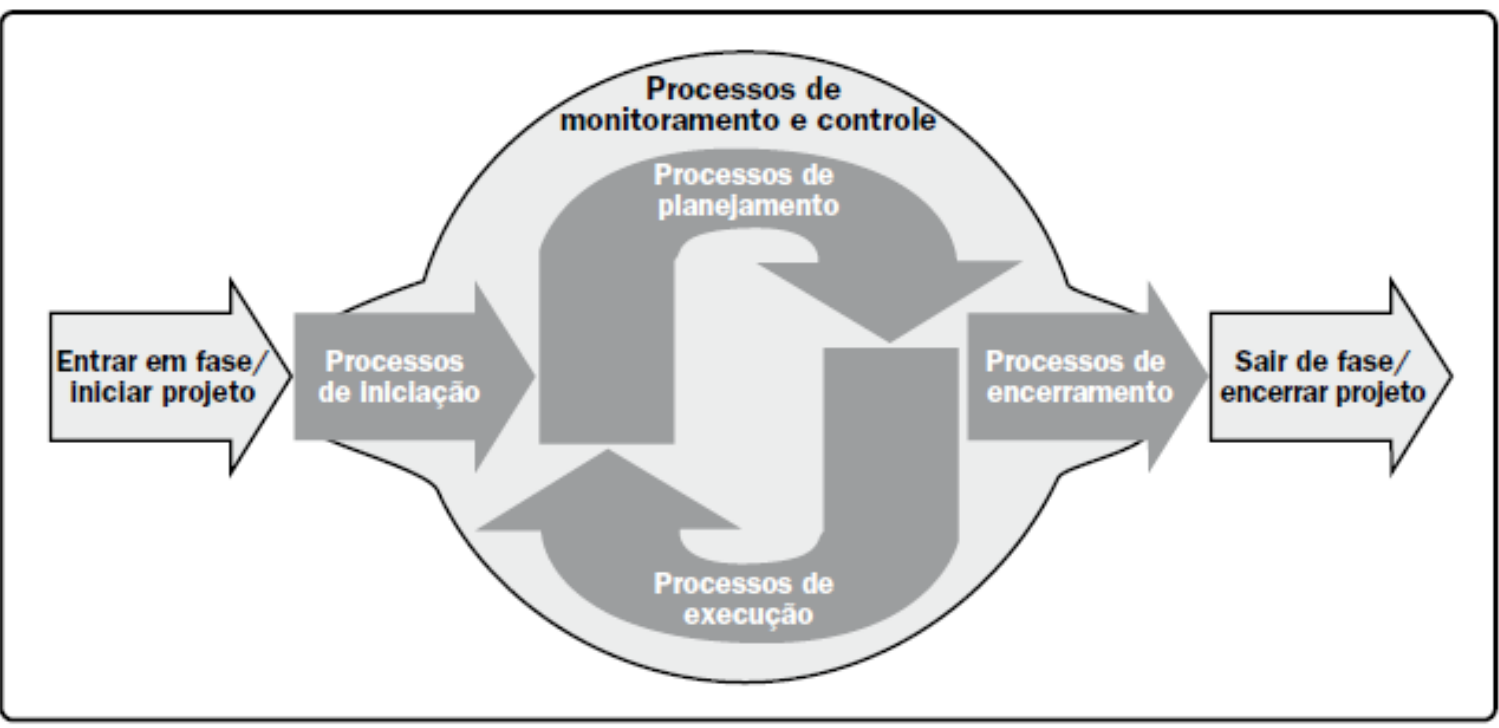

Fonte: PMI (2013) 
Figura 13 - Os grupos de processos interagem em uma fase ou em um projeto

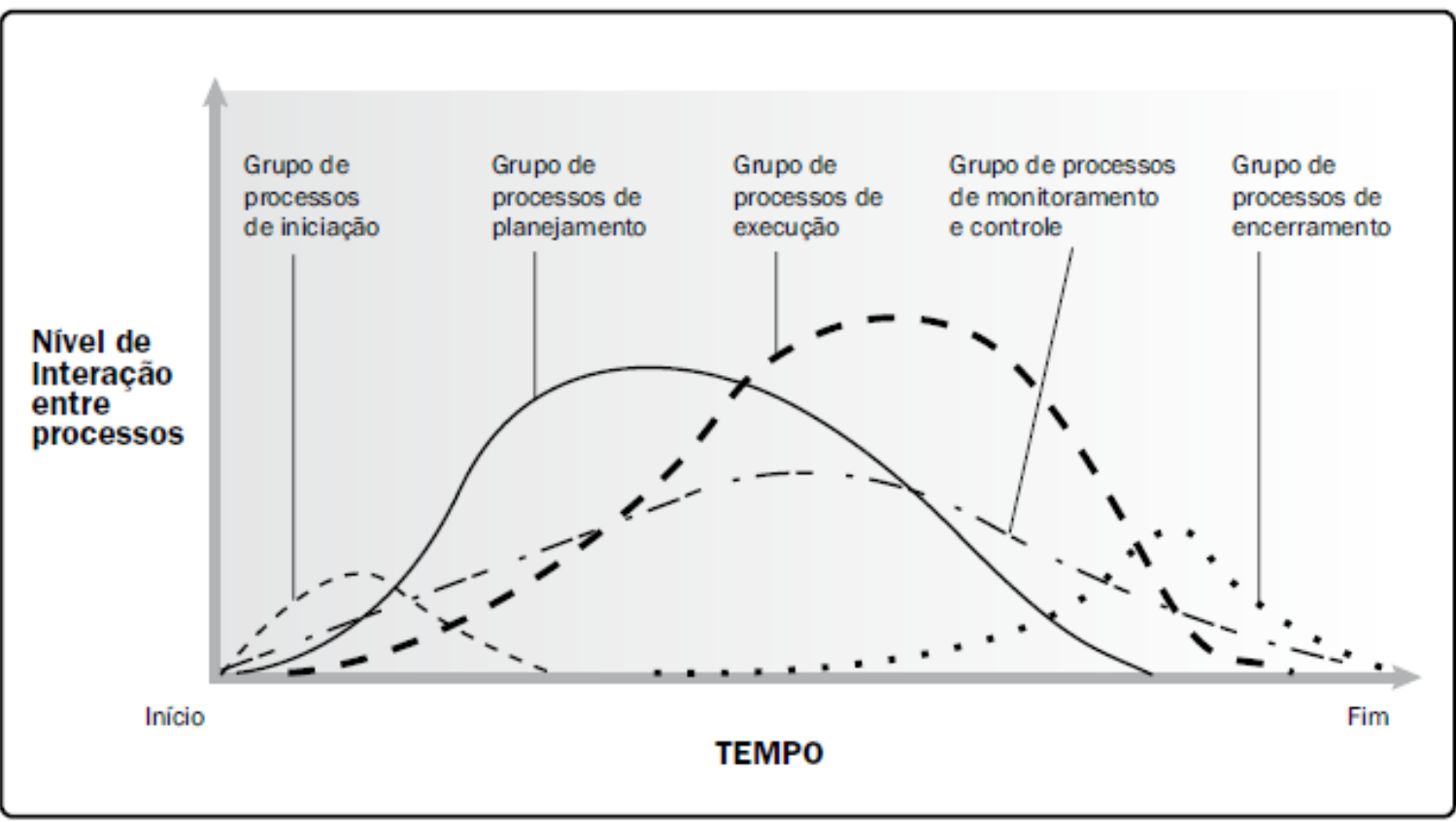

Fonte: PMI (2013)

É possível ver que na Figura 14 os grupos de gerenciamento de processos se relacionam com as áreas do conhecimento e preveem o mapeamento do que deve ser feito para garantirem a efetividade da gestão do projeto. Na etapa de iniciação é necessário começar pelo Termo de Abertura do Projeto, que se trata de um documento que define a existência do projeto e é essencial ao gestor para garantir os recursos necessários inerentes a ele. Também deve ser feita a identificação dos envolvidos no projeto de implantação e averiguar as suas partes interessadas. 
Figura 14 - Grupo de processos de gerenciamento de projetos

\begin{tabular}{|c|c|c|c|c|c|}
\hline \multirow[b]{2}{*}{$\begin{array}{l}\text { Áreas de } \\
\text { conhecimento }\end{array}$} & \multicolumn{5}{|c|}{ Grupos de de processos de gerenciamento de projetos } \\
\hline & $\begin{array}{c}\text { Grupo de } \\
\text { processos } \\
\text { de iniciaçào }\end{array}$ & $\begin{array}{c}\text { Grupo de } \\
\text { processos de } \\
\text { planejamento }\end{array}$ & $\begin{array}{c}\text { Grupo de } \\
\text { processos } \\
\text { de execuçào }\end{array}$ & $\begin{array}{l}\text { Grupo de } \\
\text { processos de } \\
\text { monitoramento } \\
\text { e controle }\end{array}$ & $\begin{array}{c}\text { Grupo de } \\
\text { processos de } \\
\text { encerramento }\end{array}$ \\
\hline $\begin{array}{l}\text { 4. Gerenciamento } \\
\text { da integração } \\
\text { do projeto }\end{array}$ & $\begin{array}{l}4.1 \text { Desenvolver o } \\
\text { termo de abertura } \\
\text { do projeto }\end{array}$ & $\begin{array}{l}4.2 \text { Desemvolver o } \\
\text { plano de } \\
\text { gerenciamento do } \\
\text { projeto }\end{array}$ & $\begin{array}{l}4.3 \text { Orientar e } \\
\text { gerenciar o trabalho } \\
\text { do projeto }\end{array}$ & $\begin{array}{l}\text { 4.4 Monitorare } \\
\text { controlar o trabal ho } \\
\text { do projeto } \\
4.5 \text { Realizar o } \\
\text { controle integrado } \\
\text { de mudanças }\end{array}$ & $\begin{array}{l}4.6 \text { Encerrar o } \\
\text { projeto ou fase }\end{array}$ \\
\hline $\begin{array}{l}\text { 5. Gerenciamento } \\
\text { do escopo do } \\
\text { projeto }\end{array}$ & & $\begin{array}{l}\text { 5.1 Planejar o } \\
\text { gerenciamento do } \\
\text { escopo } \\
5.2 \text { Coletar os } \\
\text { requisitos } \\
5.3 \text { Definir o escopo } \\
5.4 \text { Criar a estrutura } \\
\text { analitica do projeto } \\
\text { (EAP) }\end{array}$ & & $\begin{array}{l}5.5 \text { Va lidar o escopo } \\
5.6 \text { Controlar o } \\
\text { escopo }\end{array}$ & \\
\hline $\begin{array}{l}\text { 6. Gerenciamento } \\
\text { do tempo do } \\
\text { projeto }\end{array}$ & & $\begin{array}{l}6.1 \text { Planejar o } \\
\text { gerenciamento do } \\
\text { cronograma } \\
6.2 \text { Definir as } \\
\text { atividades } \\
6.3 \text { Sequenciar as } \\
\text { atividades } \\
6.4 \text { Estimar os } \\
\text { recursos das } \\
\text { atividades } \\
6.5 \text { Estimar as } \\
\text { duracoes das } \\
\text { atividades } \\
6.6 \text { Desernolver o } \\
\text { cronograma }\end{array}$ & & $\begin{array}{l}6.7 \text { Controlar o } \\
\text { cronograma }\end{array}$ & \\
\hline $\begin{array}{l}\text { 7. Gerenciamento } \\
\text { dos custos do } \\
\text { projeto }\end{array}$ & & $\begin{array}{l}7.1 \text { Planejar o } \\
\text { gerenciamento dos } \\
\text { custos } \\
7.2 \text { Estimar os } \\
\text { custos } \\
7.3 \text { Determinar o } \\
\text { orçamento }\end{array}$ & & $\begin{array}{l}7.4 \text { Controlar os } \\
\text { custos }\end{array}$ & \\
\hline $\begin{array}{l}\text { 8. Gerenciamento } \\
\text { da qualidade do } \\
\text { projeto }\end{array}$ & & $\begin{array}{l}\text { 8.1 Planejar o } \\
\text { gerenciamento da } \\
\text { qualidade }\end{array}$ & $\begin{array}{l}8.2 \text { Real izara } \\
\text { garantia da } \\
\text { qua lidade }\end{array}$ & $\begin{array}{l}8.3 \text { Controlar a } \\
\text { qualidade }\end{array}$ & \\
\hline $\begin{array}{l}\text { 9. Gerenciamento } \\
\text { dos recursos } \\
\text { humanos do } \\
\text { projeto }\end{array}$ & & $\begin{array}{l}\text { 9.1 Planejar o } \\
\text { gerenciamento dos } \\
\text { recursos humanos }\end{array}$ & $\begin{array}{l}\text { 9.2 Mobilizar a } \\
\text { equipe do projeto } \\
\text { 9.3 Desenvolver a } \\
\text { equipe do projeto } \\
\text { 9.4 Gerenciar a } \\
\text { equipe do projeto }\end{array}$ & & \\
\hline $\begin{array}{l}\text { 10. Gerenciamento } \\
\text { dos recursos de } \\
\text { comunicaçōes } \\
\text { do projeto }\end{array}$ & & $\begin{array}{l}\text { 10.1 Planejar o } \\
\text { gerenciamento das } \\
\text { comunicaøōes }\end{array}$ & $\begin{array}{l}10.2 \text { Gerenciar as } \\
\text { œmunicaçōes }\end{array}$ & $\begin{array}{l}10.3 \text { Controlar as } \\
\text { comunicaçōes }\end{array}$ & \\
\hline $\begin{array}{l}\text { 11. Gerenciamento } \\
\text { dos riscos do } \\
\text { projeto }\end{array}$ & & $\begin{array}{l}11.1 \text { Planejar o } \\
\text { gerenciamento dos } \\
\text { riscos } \\
11.2 \text { ident ificar os } \\
\text { riscos } \\
11.3 \text { Real izar a } \\
\text { anâlise qua litativa } \\
\text { dos riscos } \\
11.4 \text { Real izar a } \\
\text { análise quantitativa } \\
\text { dos riscos } \\
11.5 \text { Planejar as } \\
\text { respostas aos riscos }\end{array}$ & & $\begin{array}{l}11.6 \text { Controlar os } \\
\text { riscos }\end{array}$ & \\
\hline $\begin{array}{l}\text { 12. Gerenciamento } \\
\text { das aquisiçöes } \\
\text { do projeto }\end{array}$ & & $\begin{array}{l}12.1 \text { Planejar o } \\
\text { gerenciamento das } \\
\text { aquisiç̧ōes }\end{array}$ & $\begin{array}{l}12.2 \text { Conduzir as } \\
\text { aquisiçōes }\end{array}$ & $\begin{array}{l}12.3 \text { Controlar as } \\
\text { aquisiçōes }\end{array}$ & $\begin{array}{l}12.4 \text { Encerrar as } \\
\text { aquisi } \cos \end{array}$ \\
\hline $\begin{array}{l}\text { 13. Gerenciamento } \\
\text { das partes } \\
\text { interessadas } \\
\text { no projeto }\end{array}$ & $\begin{array}{l}13.1 \text { Ident ificar as } \\
\text { partes interessadas }\end{array}$ & $\begin{array}{l}\text { 13.2 Planejaro } \\
\text { gerenciamento das } \\
\text { partes interessadas }\end{array}$ & $\begin{array}{l}13.3 \text { Gerenciar o } \\
\text { engajamento das } \\
\text { partes interessadas }\end{array}$ & $\begin{array}{l}13.4 \text { Controlar o } \\
\text { engajamento das } \\
\text { partes interessadas }\end{array}$ & \\
\hline
\end{tabular}

Fonte: PMI (2013) 
Conforme descrito em PMI (2013), em seguida, a etapa de planejamento se inicia e é necessário desenvolver o Plano de Gerenciamento do Projeto composto por linhas de base e planos auxiliares. Ele é um documento que pode ser completo ou resumido e após estabelecido não deverá sofrer alterações, porque define como o projeto será efetuado, acompanhado e gerenciado. Após essa parte, ainda é necessário listar os requisitos do plano de adoção e determinar o escopo do projeto para completar o seu plano de gerenciamento.

Em seguida deverá ser desenvolvida uma Estrutura Analítica do Projeto para que ele seja subdividido em fases e fiquem mais claro os processos que devem ser realizados. A partir dessa decomposição, as atividades detalhadas deverão ser estabelecidas, assim como o seu sequenciamento e os recursos necessários. Deverão ser planejados os recursos humanos que serão necessários para a implantação do BIM, a qualidade mínima esperada para o projeto, o plano de comunicação entre os diferentes interessados e as formas de contratação. Além disso, os riscos deverão ser identificados, analisados, qualitativa e quantitativamente, e gerenciados. A partir desse momento será possível gerar o cronograma do projeto e prever os custos totais dele. A alta hierarquia deverá ser envolvida para que o orçamento do projeto seja aprovado.

$\mathrm{Na}$ fase de execução, as empresas deverão realizar o gerenciamento da execução do projeto, garantindo que o que foi planejado está sendo cumprido; acompanhar o andamento e a forma que ele está sendo desenvolvido para garantir a qualidade prevista; colocar em prática a contratação de equipe especializada; executar os planos de treinamento para desenvolver a equipe interna e os novos colaboradores no tema; garantir a distribuição e o recebimento das informações; gerenciar as expectativas dos envolvidos no projeto; e realizar as contratações planejadas;

$\mathrm{Na}$ fase de controle deverá ser feito o acompanhamento de tudo o que foi planejado, como a administração das etapas e das atividades previstas, dos custos, do escopo, do progresso, da qualidade, dos riscos, das contratações e das mudanças, visto o impacto que elas causam no processo de trabalho. Em seguida, na etapa de encerramento, deverá ser feita a finalização das fases de cada projeto e dele, completamente. Essas partes estão previstas nas interações do processo de gerenciamento de projetos do PMBOK, conforme a Figura 15. 
Figura 15 - Interações nos processos de gerenciamento de projetos

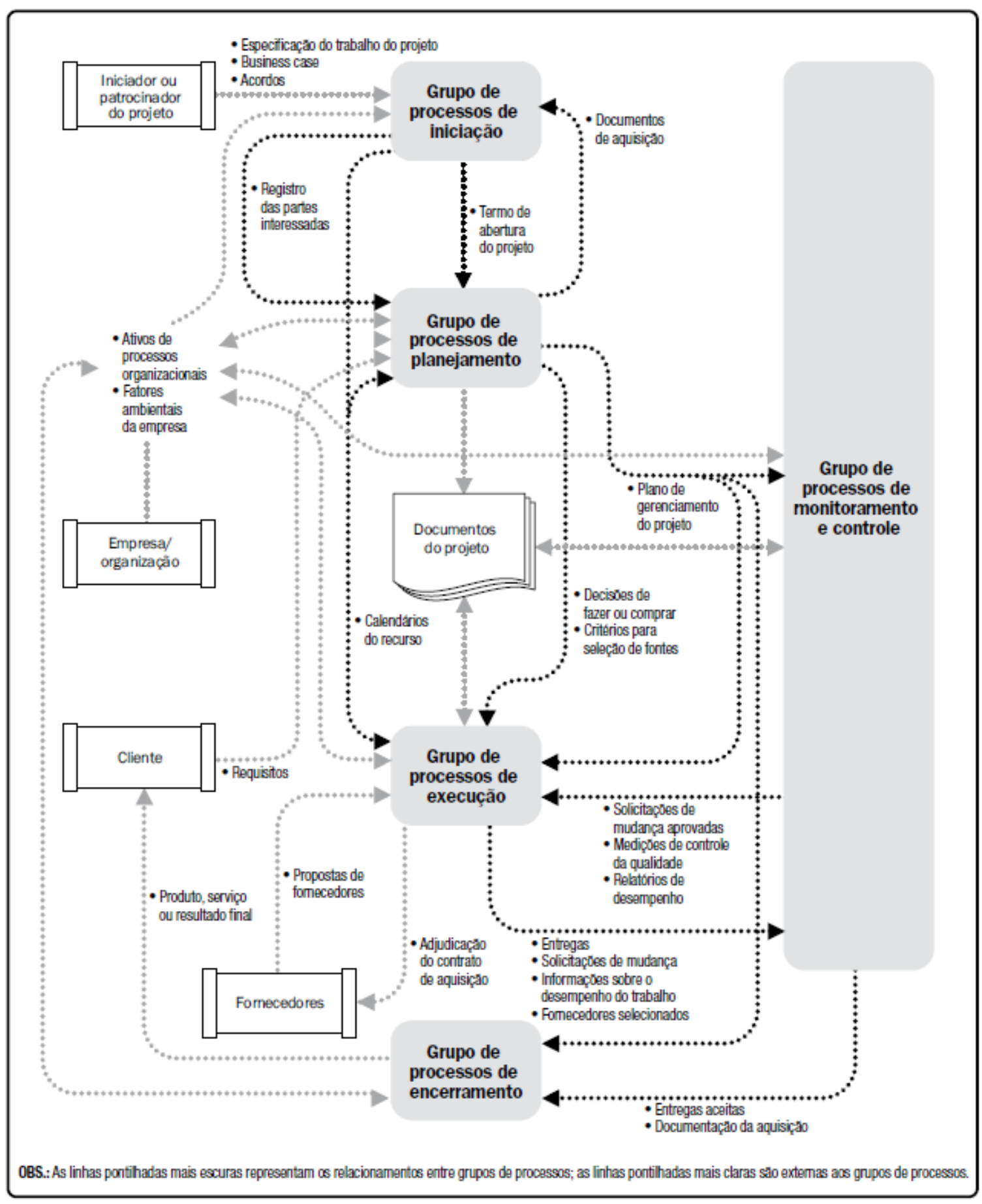

Fonte: PMI (2013) 


\subsection{Desafios de implantação e uso do BIM}

Existem obstáculos que surgem durante o processo de adoção do BIM em toda a cadeia produtiva da Construção Civil, que dificultam ou impedem a adoção, a utilização e a entrega de projetos BIM. Essas dificuldades foram mapeadas pelos diversos agentes da cadeia produtiva e são divididas em cinco fatores diferentes no Quadro 1, sendo relativos à tecnologia, às pessoas, à comunicação, aos processos e às empresas.

Quadro 1 - Desafios para a adoção e o uso do BIM

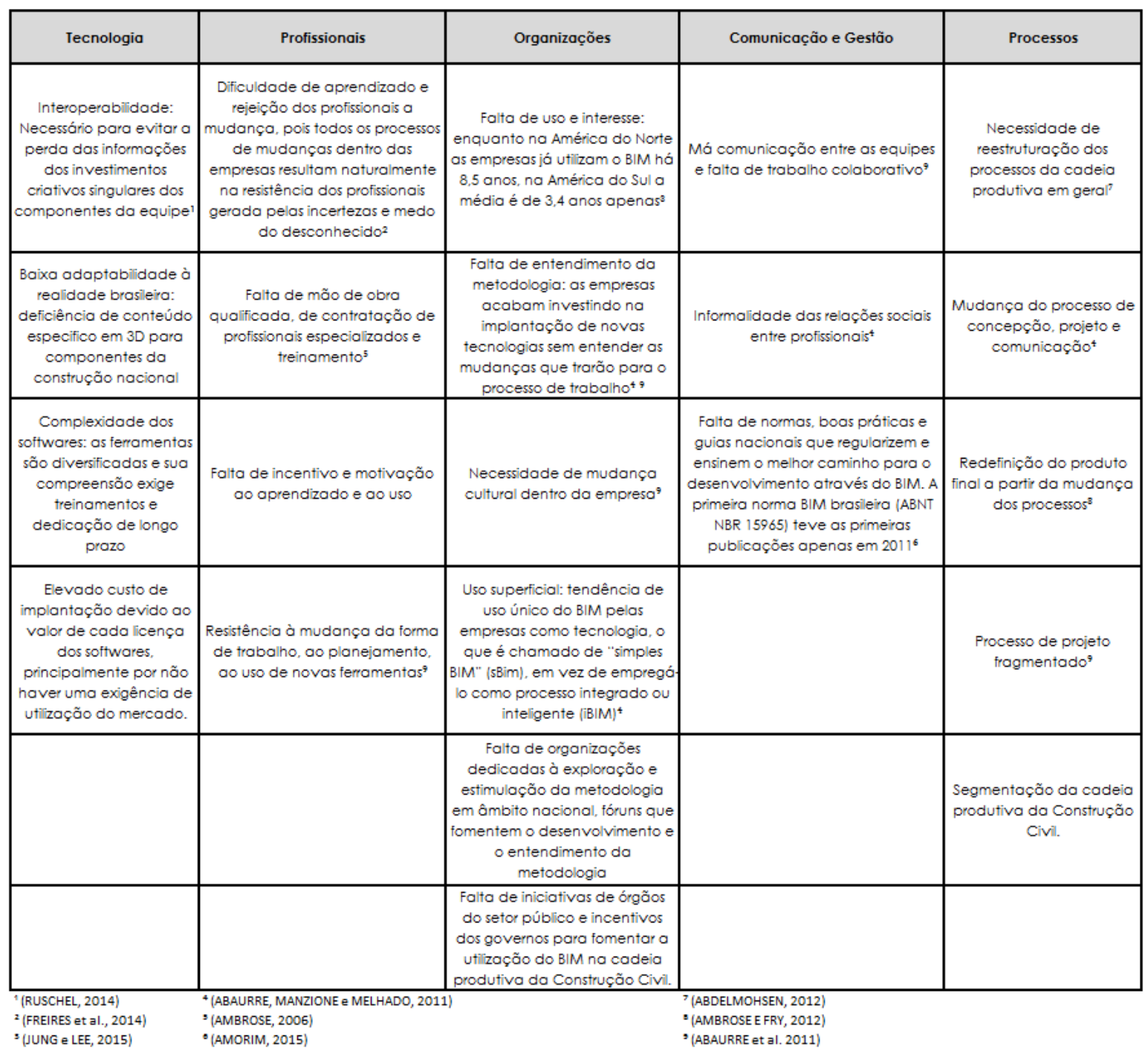

Fonte: Freitas, Melhado e Cardoso (2018) 
$\mathrm{Na}$ cadeia produtiva da construção civil existem dificuldades intrínsecas ao projeto e ao processo de trabalho, que são presentes no procedimento convencional e podem impactar na obtenção de resultados, com a implantação do BIM (ABAURRE; MANZIONE; MELHADO, 2011).

De acordo com Eastman et al. (2014), a adoção do BIM e de novas tecnologias está sendo feita de maneira fragmentada, principalmente nas empresas de grande porte, havendo a necessidade de recorrer aos projetos em papel ou CAD 2D para garantir a comunicação e o entendimento de todos os membros de uma equipe ou participantes de uma grande licitação. Portanto, enquanto esse processo de adoção e utilização não for realizado da maneira correta, o BIM não funcionará na sua totalidade e não trará os benefícios possíveis.

O uso do BIM culminará em grandes mudanças nos relacionamentos entre os agentes e os contratos, pois aqueles existentes hoje são adequados às práticas baseadas em papel. As fases que conhecemos hoje terão que ser alteradas, visto que há a necessidade de colaboração antecipada entre arquiteto, engenheiros e subempreiteiros, para que os benefícios sejam realmente alcançados. $O$ autor indica que apesar do método permitir o trabalho colaborativo, ela precisa ser desenvolvida pela definição dos métodos adequados de compartilhamento do modelo, das informações, dentre outras definições cruciais para o seu uso efetivo (EASTMAN et al., 2014).

Smith (2013) relata que na sua pesquisa identificou que um dos maiores desafios para a estimativa de custos da construção é a baixa qualidade do modelo BIM desenvolvido. É dele que saem os quantitativos para desenvolver essa orçamentação. Além disso, a falta de investimento dos proprietários para aumentar um pouco a quantidade de informações do modelo também influencia muito na estimativa e controle dos custos. É mais fácil quando essas atividades de estimativa de custos são desenvolvidas dentro da mesma empresa que desenvolveu o projeto, visto que o questionamento de informações faltantes pode ser realizado diretamente nas áreas responsáveis. Outras grandes barreiras são a falta de padronização e as incompatibilidades de softwares, que apesar das grandes melhorias que ocorreram nos últimos anos referentes a esses temas, essas questões continuam sendo impedimentos para as empresas. 
O uso de um modelo de construção compartilhado também é apontado pelo autor como um dos desafios encontrados pelos agentes ao utilizarem os softwares BIM para trabalharem. Há a necessidade de educação, treinamento e tempo para que esses profissionais amadurecerem o conhecimento referente à nova forma de trabalho proposta. Ainda existem questões ligadas à implantação do BIM nas empresas, que remetem à mudança do processo de trabalho, compreensão do significado dessas alterações e planejamento. Além disso, a escassez de trabalhadores qualificados é também um desafio para a implantação do BIM. (EASTMAN et al., 2014).

Os autores Eastman et al. (2014) indicam que algumas empresas desenvolvem os projetos em 2D e baseados em papel, então será necessário que a empresa seguinte na cadeia produtiva da construção faça o modelo para conseguir planejar a construção, realizar as estimativas, a coordenação, entre outras atividades. Essa criação posterior ao projeto pronto é trabalhosa e acresce custos e tempo ao empreendimento, mas pode ser justificada pelas vantagens da sua utilização. Além disso, apesar do BIM permitir o trabalho colaborativo, ele precisa ser desenvolvido pela definição de métodos adequados de compartilhamento do modelo, das informações, dentre outras questões que devem ser previamente planejadas. 


\section{ESTUDOS DE CASO}

Os estudos de caso foram desenvolvidos em quatro empresas de grande porte do setor de infraestrutura. Neste capítulo está registrado o processo de adoção do BIM relatado pelos profissionais entrevistados em 2018 e 2019, abordando questões relativas à motivação, início da adoção do método, áreas contempladas, formas de implantação, plano de treinamentos, materiais desenvolvidos, projetos-pilotos, planejamento, plano de adoção, benefícios, obstáculos, usos, rejeição a mudança e próximos passos.

\subsection{EMPRESA 1}

A Empresa 1 se trata de uma companhia pública, que atua no setor de transportes sobre trilhos há mais de 50 anos na Região Metropolitana de São Paulo. Possui quase 10 mil funcionários e é responsável pela operação e manutenção de 86 estações e, aproximadamente, 97 quilômetros de trilhos, além de se encarregar, também, do planejamento, do projeto e da construção dessa infraestrutura.

A empresa possui uma presidência com cinco diretorias e vinte e quatro gerências, conforme a Figura 16 abaixo. O estudo de caso nessa organização foi desenvolvido a partir de entrevistas com os profissionais da Gerência de Projeto Básico Civil - GPR, sendo a primeira área a adotar o BIM e efetivamente trabalhar com o método. Também foram realizadas análises documentais das informações disponibilizadas. 
Figura 16 - Organograma Simplificado Empresa 1

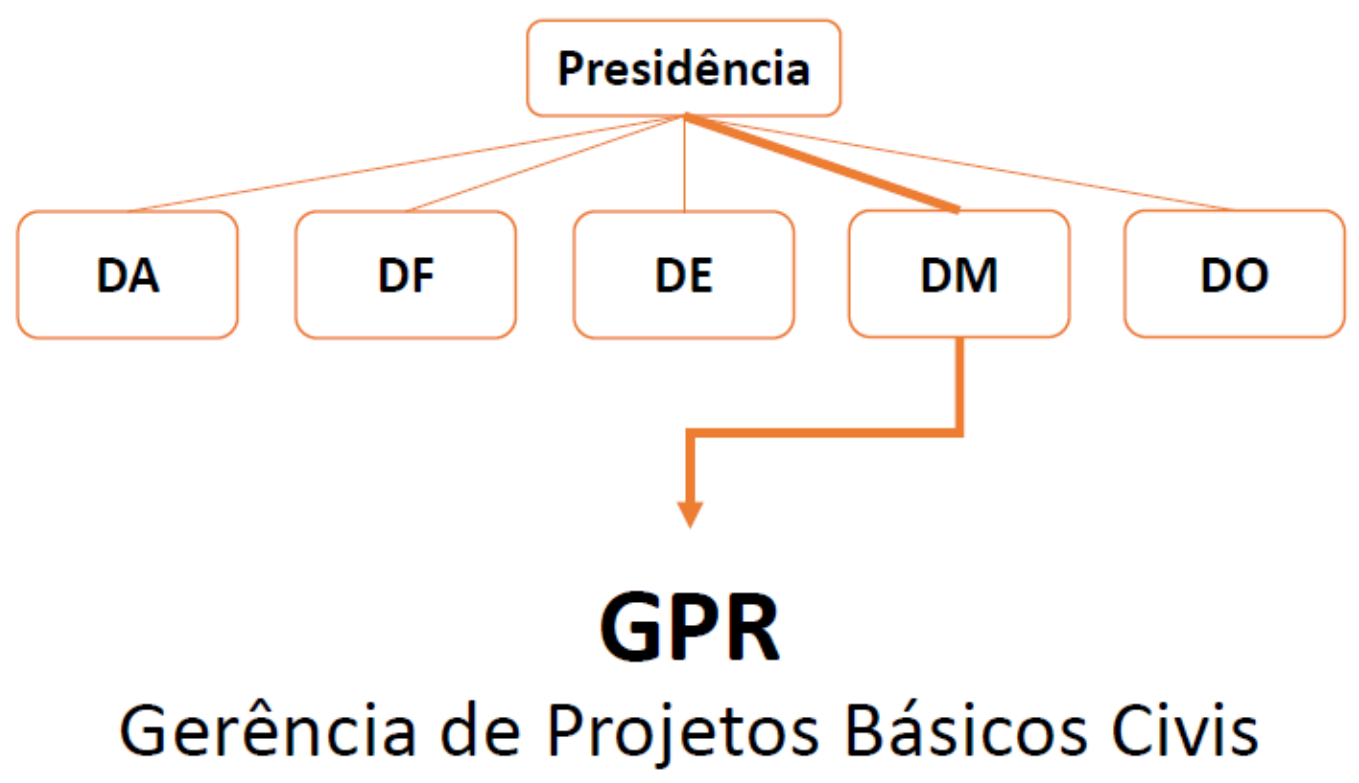

Fonte: Fornecido pela Empresa 1 (2018)

O profissional responsável pela implantação do BIM na gerência explicou que existem dois tipos de adoção dentro da empresa, sendo um o BIM da GPR, ou seja, aquele focado para as funções e os objetivos da área de Projeto Básico Civil, especificamente. Ademais, tem-se o "Inovação BIM", que é o BIM corporativo, que possui o objetivo de disseminar o método em todas as áreas da organização e implantá-la em todo o ciclo de vida do empreendimento, que se trata de um projeto de transformação da companhia para os processos BIM.

\subsubsection{BIM da GPR}

O profissional entrevistado relatou que a história do BIM nesta empresa começou em 2011, em que um grupo de técnicos participou de um evento sobre inovações na área da Engenharia Civil, conhecendo o método. Os colaboradores trouxeram a informação para a alta hierarquia, que se interessou e instruiu essa equipe a pesquisar mais a fundo sobre o tema. Durante esse período fizeram estudos e desenvolveram artigos sobre o BIM pelos anos seguintes. Em 2013, a empresa identificou a necessidade de ajuda externa para melhorar a sua compreensão sobre esse método e então identificaram duas opções: a contratação de uma consultoria ou a contratação de um profissional experiente do mercado. 
Decidiram seguir pela contratação de um profissional do mercado, o atual gerente da GPR, que se encontra dentro da Diretoria de Arquitetura. $O$ conhecimento deste profissional sobre o BIM começou em 2007, porém o seu contato profissional com o tema foi apenas em 2010, atuando em uma empresa de projetos arquitetônicos de grande porte por três anos. O processo de implantação do BIM na GPR está resumido na linha do tempo da Figura 17 e começou, então, com a contratação desse profissional, que possuía a responsabilidade de implantar o BIM na gerência e atuar com o método nos projetos básicos da empresa.

Figura 17 - Linha do tempo da implantação do BIM na Empresa 1

\section{BIM DA GPR:}

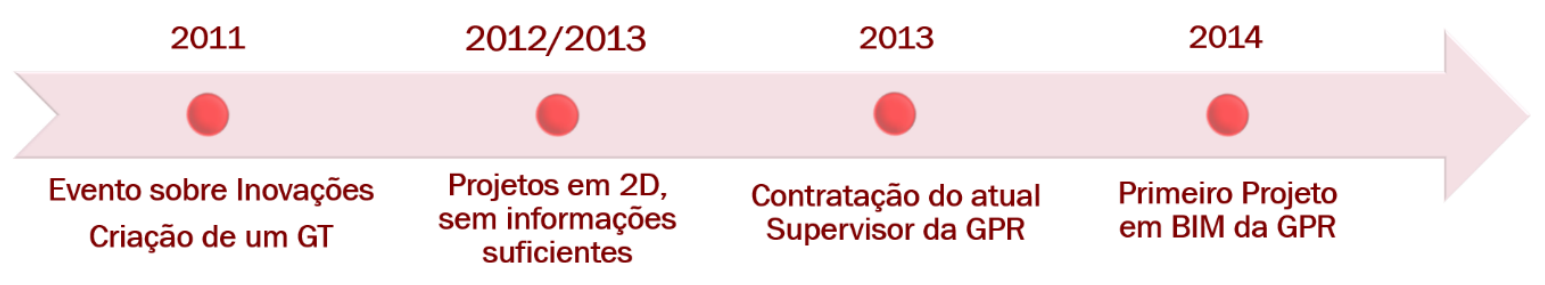

Fonte: A autora (2018)

Até 2013 a Empresa 1 relata que recebia o projeto básico em 2D com as plantas e alguns cortes, então eles não possuíam o projeto básico todo resolvido. Por esse motivo, diversas questões acabavam sem resolução e remanesciam, dessa maneira, até a etapa de projeto executivo ou até a obra. Isso se traduzia em retrabalhos, frustrações e atrasos pela organização contratada para a obra, conforme conta o responsável. Outra questão que dificultava a execução dos projetos dessa maneira era o prazo que estava cada vez mais curto para as etapas de projeto executivo e obra, ocasionando diversos problemas e atrasos, o que vai contra a necessidade evidente de antecipação das obras de infraestrutura, que são de grande importância para o estado.

O profissional conta que o primeiro projeto em BIM finalizado pela empresa após a sua vinda foi o de uma estação da extensão de uma das linhas, no qual abriram uma licitação, tipo concorrência internacional, em agosto de 2013. O escopo dessa contratação foi o desenvolvimento do projeto básico. A empresa foi contratada em maio de 2014 e o prazo para o desenvolvimento do escopo da elaboração do projeto básico de arquitetura e engenharia civil foi de 16 meses, mas houve algumas prorrogações de prazo durante a vigência do contrato. 
A licitação indicava que o método BIM e as suas ferramentas deveriam ser utilizadas no desenvolvimento desse projeto para garantir a qualidade e seguir o manual específico de diretrizes para o desenvolvimento do modelo 3D, com o objetivo de conter todas as informações necessárias e relevantes para posteriores usos, como planejamento, compras e construção. A empresa desenvolveu um Manual de Diretrizes BIM, que indica a necessidade do modelo paramétrico em permitir a determinação de conflitos entre as disciplinas de projetos, a compatibilização entre eles, a análise de alternativas construtivas e a extração de quantitativos. Quando a licitação foi lançada, o documento ainda não estava pronto, porém, quando a empresa foi contratada ele já estava finalizado.

A contratante desenvolveu então um Plano de Execução BIM junto com a contratada, deixando claro os usos e os objetivos do modelo a ser desenvolvido. $O$ objetivo inicial foi o de melhorar as etapas de compatibilização e quantificação, além de simplificar a análise dos projetos que agora seriam em 3D. A empresa contratada para o desenvolvimento do projeto básico iniciou o projeto em BIM e seguiu o processo padrão da Empresa 1, que se resume em contínuas entregas, revisões e devolutivas, conforme se pode verificar nas Figuras 18 e 19 e 20. Durante essas revisões foi possível realizar a detecção de interferências no modelo, a partir da compatibilização de todas as disciplinas, conforme a Figura 18.

Figura 18 - Detecção de interferência

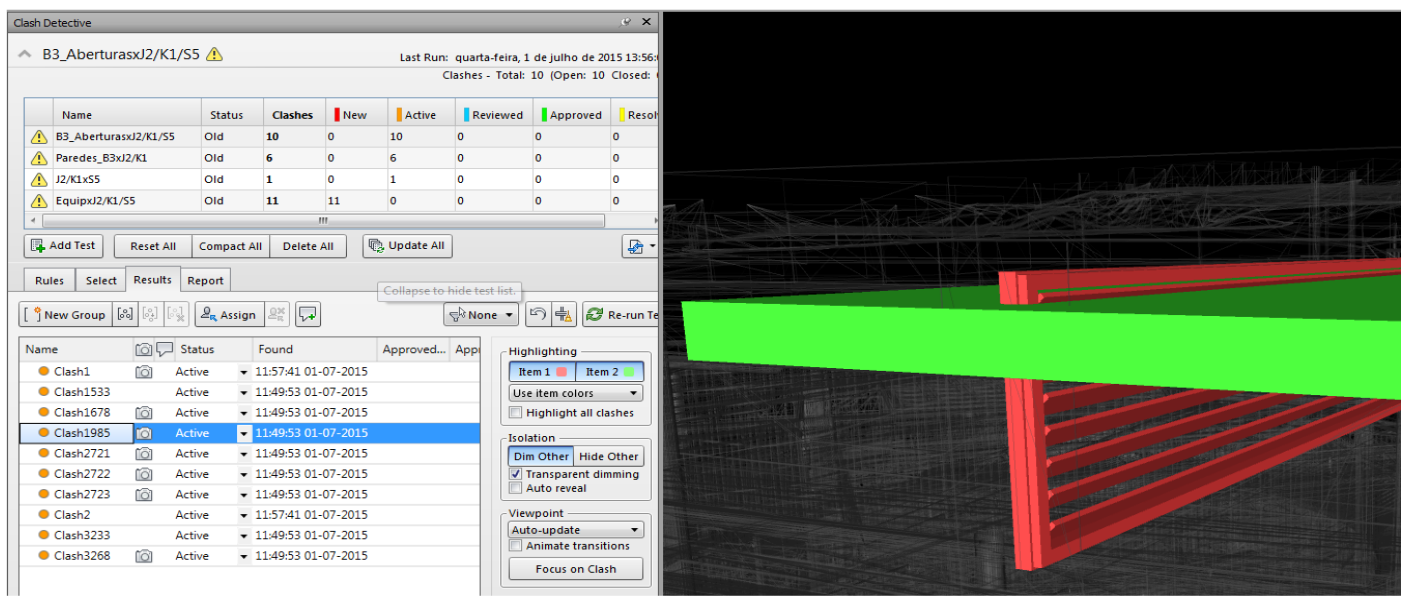

Fonte: Fornecido pela Empresa 1 (2018) 
O projeto foi finalizado em 2015 e foi relatado pelos colaboradores que o primeiro ganho que verificaram com essa experiência foi a antecipação das tomadas de decisões para a fase de projeto básico, o que antes ocorria em fases posteriores, como a de projeto executivo ou obra, causando retrabalho. Nessa etapa já tiveram o projeto inteiro em 3D praticamente todo resolvido, diferente dos anteriores, conforme relato do responsável da área. O processo de análise do projeto foi simplificado na opinião do profissional e se tornou mais rápido com a possibilidade do modelo ser analisado de forma paralela e por um arquivo digital. Outro benefício verificado pelos profissionais com essa experiência foi a condução das reuniões do projeto, que se tornaram mais objetivas, rápidas e eficazes com o modelo paramétrico, pois gerou uma melhor visualização do projeto para todos os envolvidos e, consequentemente, discussões melhor estruturadas e de maior compreensão. Além disso, foi possível envolver outras gerências nesse momento, o que permitiu antecipar a necessidade de alterações para a etapa do projeto básico, no qual o esforço é menor, dando maior eficiência ao processo de trabalho.

Figura 19 - Projeto preliminar da estação

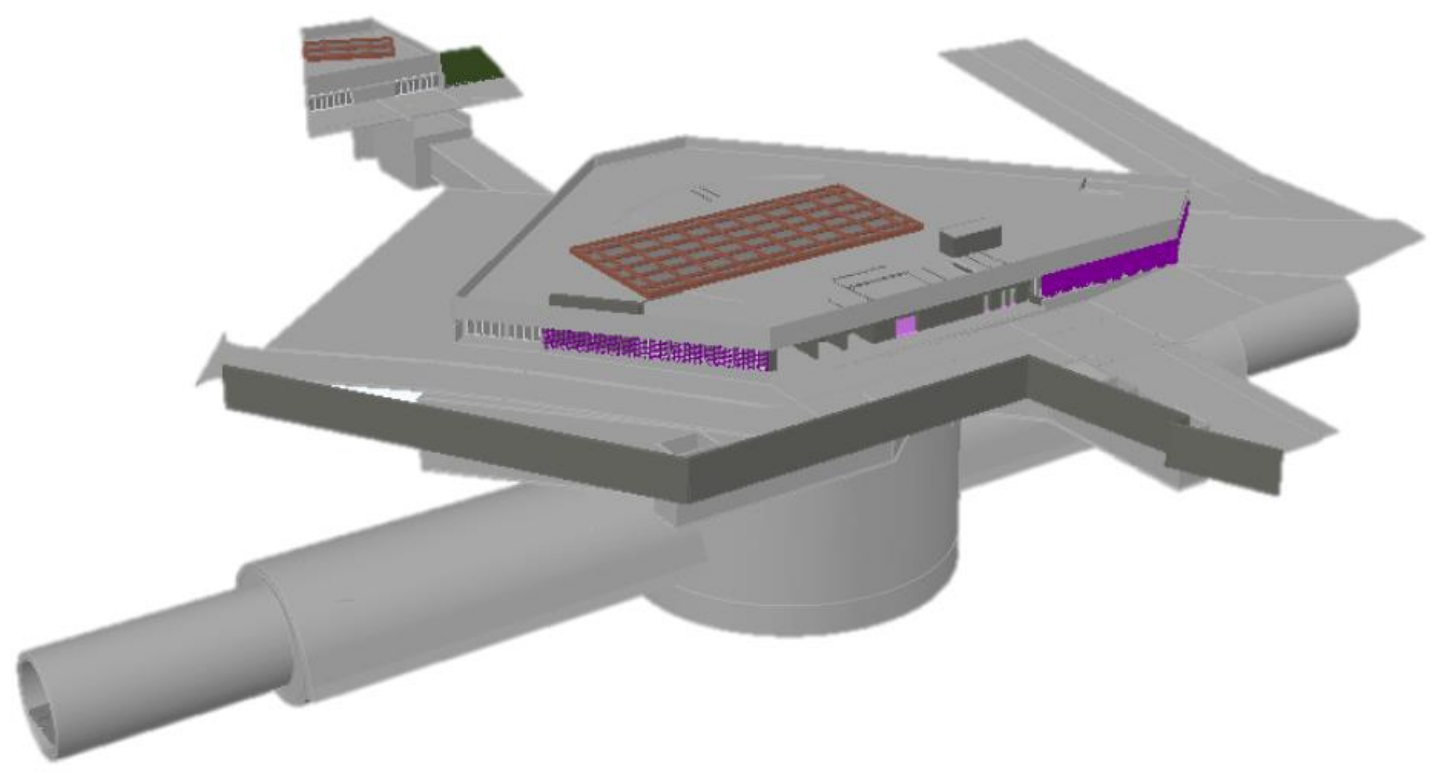

Fonte: Fornecido pela Empresa 1 (2019) 
Figura 20 - Exemplo de análise de folha realizada digitalmente

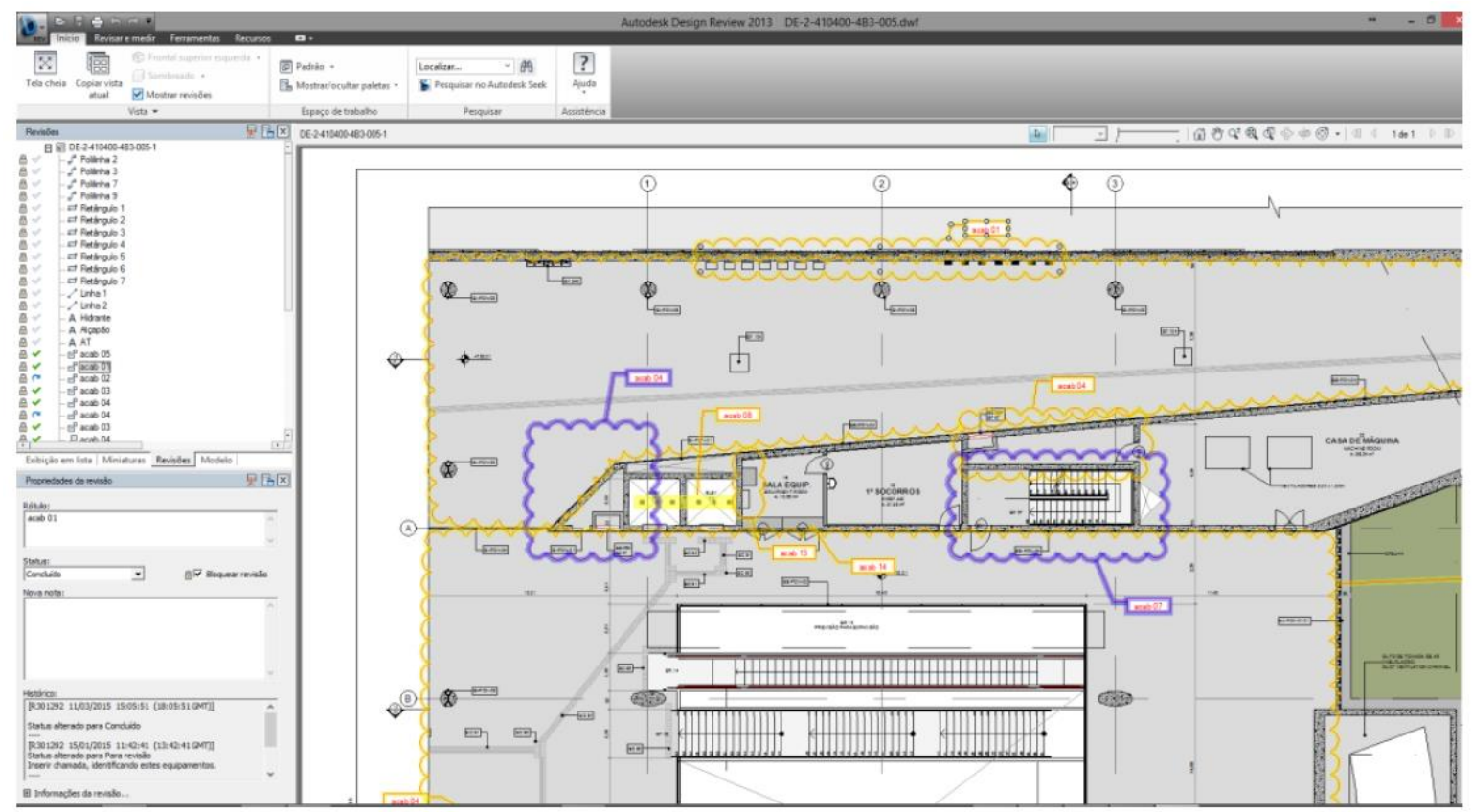

Fonte: Fornecido por Empresa 1 (2018)

Os profissionais entrevistados contam que durante o desenvolvimento dessa primeira experiência foi necessário também desenvolver algumas métricas para justificar a adoção do BIM na empresa. Como novas implantações geram custos e rejeição dos envolvidos, para combater isso e justificar a mudança foi necessário mostrar os resultados de retorno de uma maneira coerente.

Além disso, um dos profissionais pontua que outra questão a ser considerada é a alta hierarquia, pois em 2013 ela apoiava e fomentava a adoção do BIM. Os colaboradores contam que recentemente os responsáveis mudaram e, portanto, há a necessidade de criar indicadores para defender o projeto dentro da empresa. Com base nessa filosofia, no que tange à falta de conhecimento sobre o BIM dentro da empresa e no que concerne à falta de apoio à implantação desse método, o profissional responsável conta que identificou a oportunidade de coletar medições durante o primeiro projeto para suportar essa questão posteriormente.

O produto final entregue (Figura 21) pela empresa contratada foram 7 modelos, conforme se pode depreender na Figura 22, desenvolvidos para três grandes projetos: Arquitetura, Estrutura e Sistemas, o que demorou o total de 16 meses para ser concluído, conforme relata o profissional da companhia. Os colaboradores contam que esses modelos não possuíam todos os usos possíveis do BIM, porque optaram por começar aos poucos para entenderem a maneira de 
se trabalhar com o método e então, posteriormente, amadurecerem o conhecimento em novos projetos. A primeira entrega do projeto seguiu um processo de trabalho semelhante ao existente na empresa: a distribuição dos projetos de cada disciplina para os responsáveis, análise, inserção de comentários em cada um deles e devolução para a revisão da empresa projetista contratada. A diferença foi a criação de uma fase inicial de validação do modelo, de acordo com as regras estabelecidas e padronização, realizada pelo gerente da área.

Figura 21 - Modelo BIM vista 3D

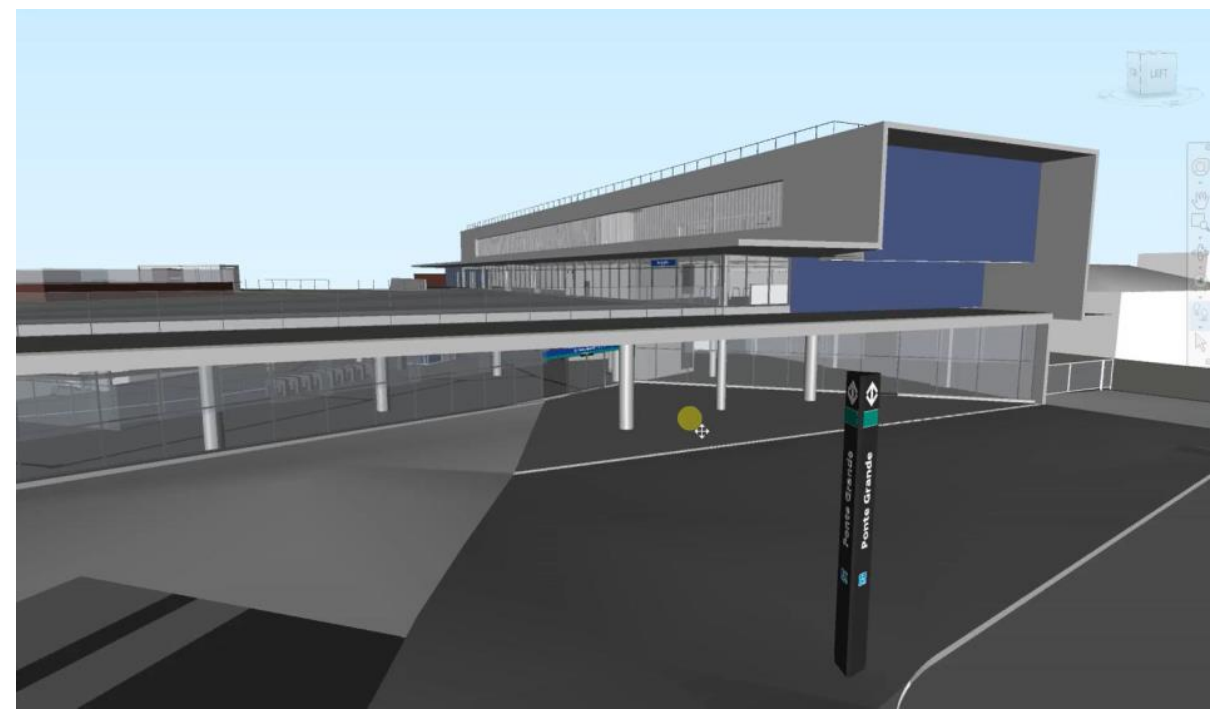

Fonte: Fornecido pela Empresa 1 (2019)

Figura 22 - Modelos desenvolvidos

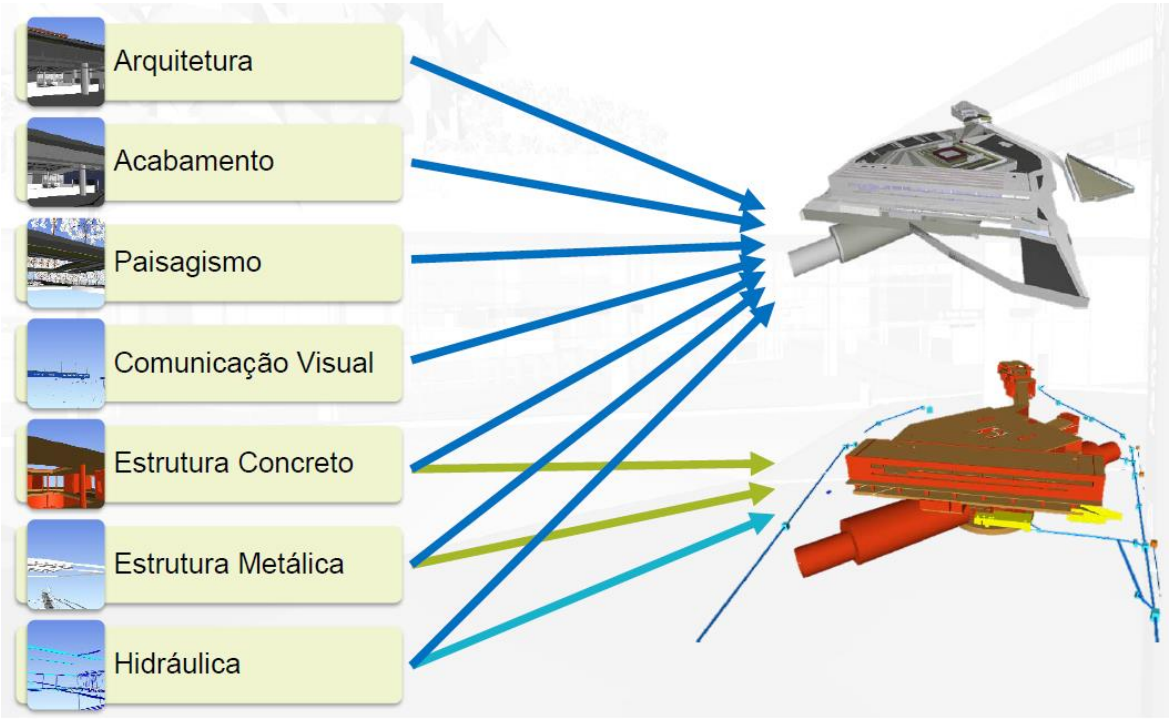

Fonte: Fornecido pela Empresa 1 (2019) 
A partir dos comentários realizados pela Empresa 1, categorizaram eles em quatro tipos, sendo: comentários sobre a representação gráfica; sobre a natureza da folha; sobre a natureza do projeto e sobre a natureza da documentação. Essas classificações de comentário foram feitas para esse primeiro projeto em BIM e, paralelamente, para um projeto que estava sendo desenvolvido na maneira convencional. Ao final, os resultados obtidos pela organização foram apresentados em um gráfico de medição de esforço da seguinte maneira:

\section{Gráfico 5 - Quantidade de comentários por revisão de projeto}

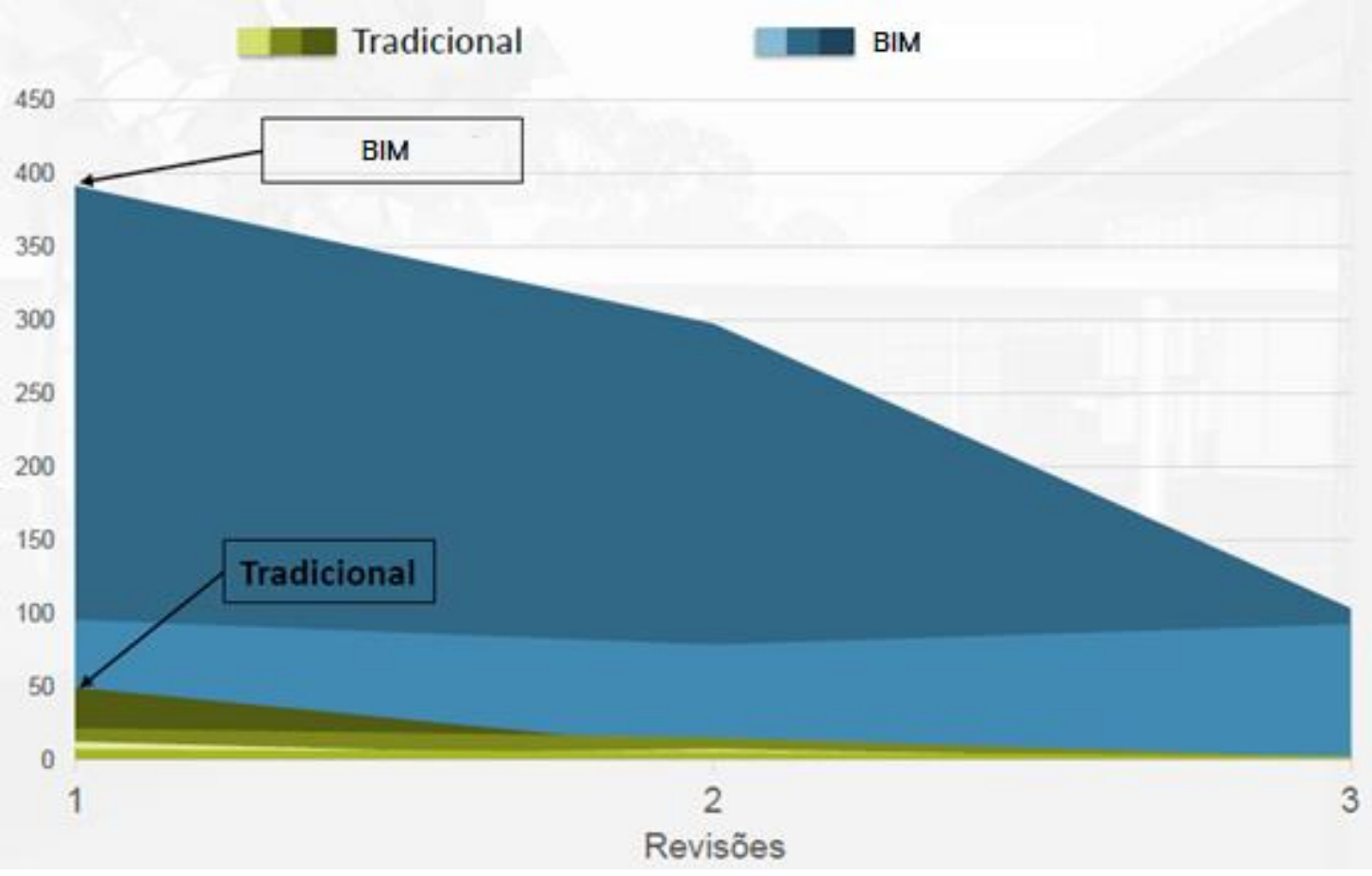

Fonte: Adaptado da documentação fornecida pela Empresa 1

No Gráfico 5 o profissional indica que é possível ver que os projetos desenvolvidos da maneira tradicional tiveram no máximo 100 comentários em qualquer uma das três revisões realizadas, enquanto o projeto desenvolvido em BIM possuiu quase 400 comentários em apenas uma das revisões. Apesar disso, aparentar que os projetos em BIM possuem mais problemas e, portanto, mais comentários, é uma interpretação incorreta. Os profissionais explicam que na realidade esse gráfico revela a grande quantidade de soluções e incompatibilidades que são possíveis identificar nessa etapa com o emprego desse método, o que antecipa as decisões de projeto e os problemas construtivos. Além desse benefício, outra grande melhoria que o projeto desenvolvido em BIM trouxe para o contratante 
responsável pela revisão desses projetos foi a diminuição do tempo de análise, conforme se pode verificar no gráfico 6 e na análise dos colaboradores.

Gráfico 6 - Tempo de análise por disciplina de projeto em dias

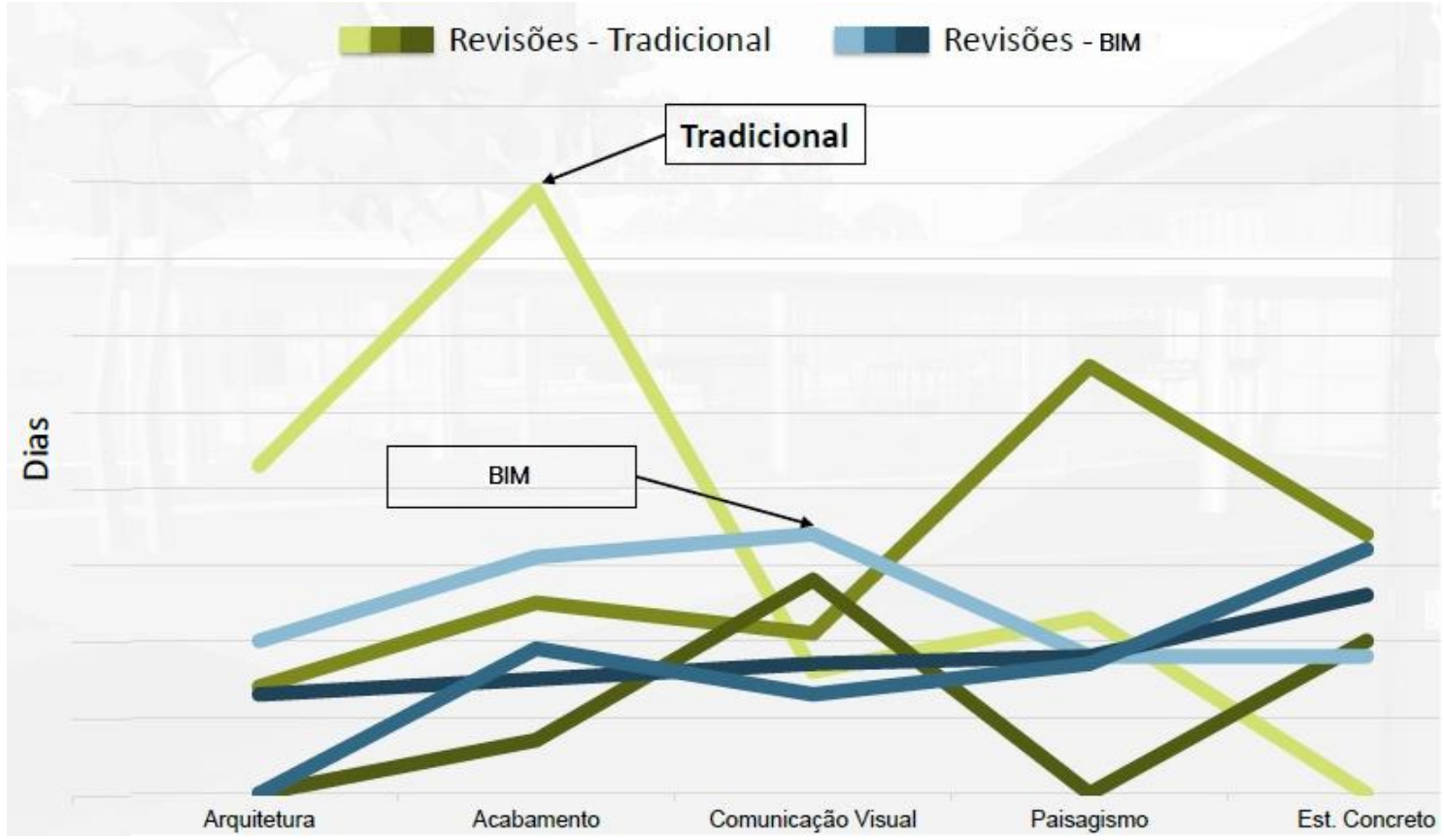

Fonte: Adaptado da documentação fornecida pela Empresa 1

As linhas verdes representam as três fases de revisão do projeto tradicional. O tempo de duração da primeira revisão das disciplinas de arquitetura e acabamento eram dois e meio e cinco dias maiores, respectivamente do que na primeira revisão, seguindo o processo BIM com o modelo, conforme explica o coordenador da organização. Durante a segunda revisão é possível ver novamente a diminuição do tempo dessas atividades, dessa vez em todas as disciplinas. Apesar da diminuição de tempo de revisão em várias disciplinas, a quantidade dos comentários utilizando o método BIM foi mais de cinco vezes maior na segunda revisão e mais de sete vezes maior na terceira revisão, sendo um total de 87 comentários feitos durante as três revisões do projeto convencional e 624 comentários no projeto em BIM. Portanto, o profissional conclui que a produtividade e a eficiência da análise foram aumentadas.

Para os profissionais isso reflete a quantidade de incompatibilidades e soluções que foram antecipadas para a etapa de projeto básico. Portanto, quanto melhor e mais bem resolvido for o projeto básico, menor será a quantidade de erros 
no projeto executivo e imprevistos na obra, diminuindo atrasos e o aumento do custo, conforme concluem os profissionais.

Além do tempo, o contratante responsável analisa também a necessidade e a importância desses comentários. No projeto sem BIM, 54\% dos comentários totais foram feitos referentes à "representação gráfica" do projeto e $20 \%$ concernente à "folha e documentação", ou seja, apreciação que não são técnicas referentes apenas ao visual do projeto. É visível que o esforço despendido no método convencional teve a finalidade pouco focada na qualidade e na adequação técnica. Por outro lado, os comentários de natureza do projeto subiram de $27 \%$ para $53 \%$ no projeto em BIM, a folha e a documentação caíram para 5\% e a representação gráfica para 41\%, conforme se pode verificar no Gráfico 7. Na opinião do gerente, o momento do projeto básico é o ideal para serem realizados os comentários referentes ao projeto, identificar as melhores soluções e reduzir as incompatibilidades, pois nesse momento os esforços de mudança são consideravelmente menores quando comparados às fases seguintes do projeto executivo e da obra. Isso vai de encontro com as informações do Gráfico 7.

Gráfico 7 - Quantidade de comentários por natureza

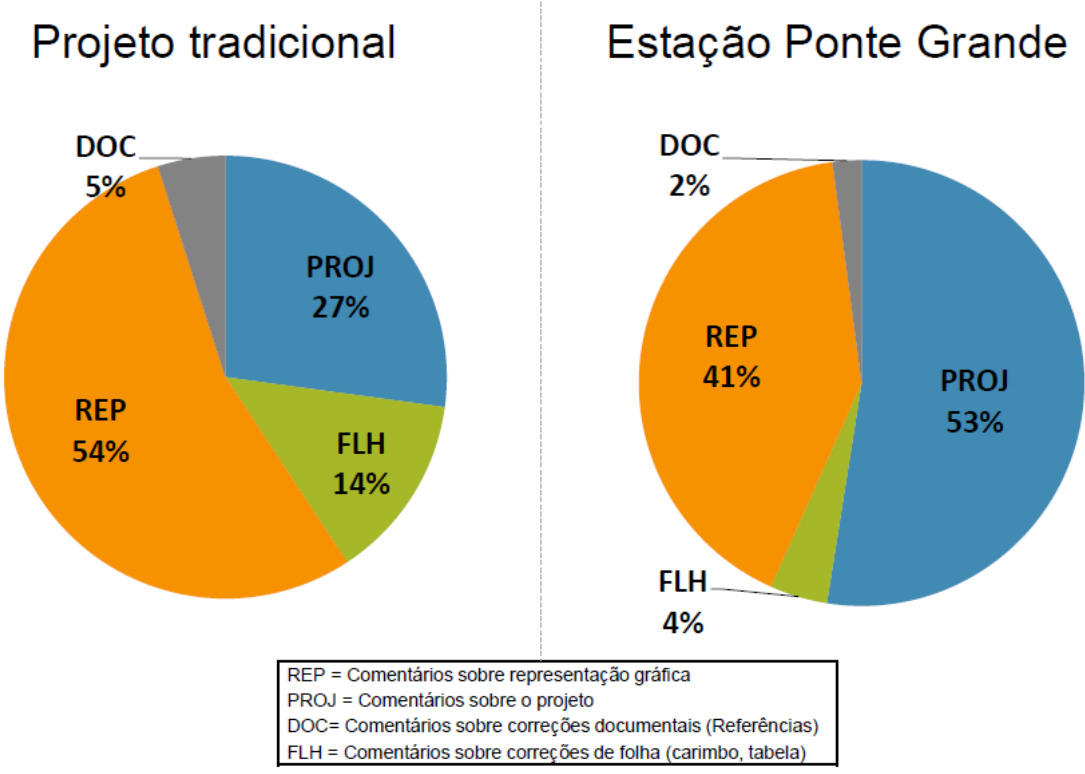

Fonte Empresa 1 (2018)

O profissional conta que até 2017 esse havia sido o único projeto (Figura 23) que foi contratado em BIM, porque a empresa é pública e o país está enfrentando há alguns anos uma crise financeira, causando a falta de novos projetos no âmbito 
da engenharia civil e da infraestrutura. No começo de 2018 iniciaram a atualização do Manual de Diretrizes BIM com a retroalimentação da experiência que tiveram para poderem estar melhor preparados para um novo projeto. Em 2017, os colaboradores contam que iniciaram um novo projeto básico em BIM em conjunto com a Empresa 2, que também teve o prazo de 16 meses, havendo a necessidade de desenvolverem um aditivo de prazo para o contrato. Esse segundo projeto básico recebeu o primeiro Prêmio BIM da Administração Pública, conforme conta o profissional.

Figura 23 - Quantidade de comentários por natureza

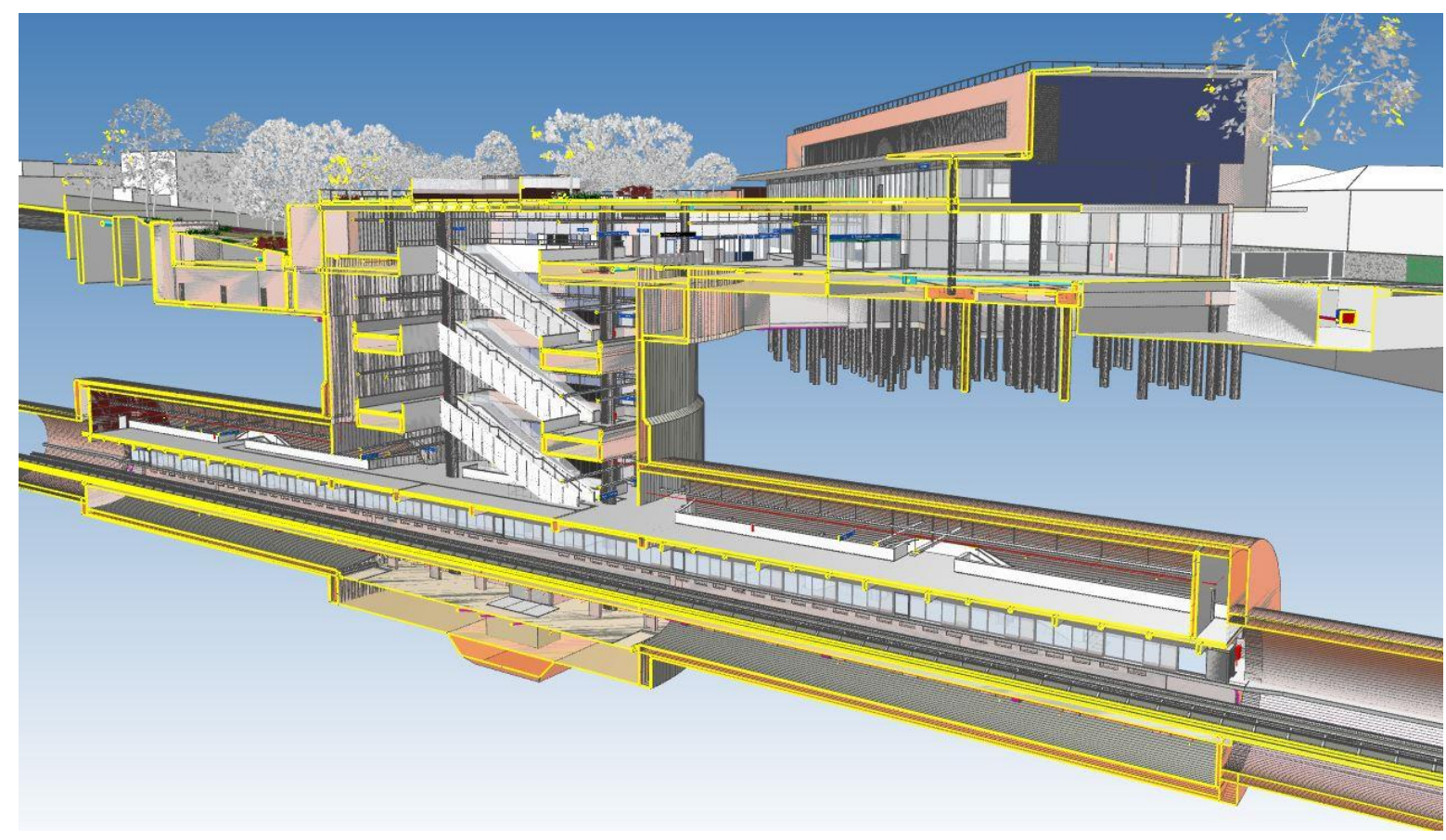

Fonte Empresa 1 (2018)

Outra decisão tomada pela GPR relatada pelo responsável foi de não criar uma biblioteca de elementos para disponibilizar para as projetistas contratadas. Um dos motivos é que eles teriam que se basear em projetos existentes para identificarem a padronização dos elementos. Contudo, esses projetos estão desatualizados, portanto há a necessidade prévia de atualização das regras e definições dos elementos.

Outra questão é que normalmente o projetista já possui as suas próprias bibliotecas de elementos padrões, sendo que o fornecedor terá algo semelhante, mas não igual, portanto, o responsável não vê a necessidade em gastar tempo e dinheiro no desenvolvimento da biblioteca de elementos específicos para a 
modelagem 3D. Por outro lado, o gerente explica que a sua equipe interna está desenvolvendo apenas os componentes que são específicos para a sua operação, ou seja, aqueles que deverão ser sempre padronizados.

Além do Manual de Diretrizes BIM, a empresa também desenvolveu um Plano de Execução BIM. O profissional ressalta que esse segundo documento deverá ser refeito a cada novo projeto, porque o conteúdo dele muda de acordo com o projeto e o contrato. O documento compreende todas as informações relacionadas, especificamente ao que será desenvolvido naquele projeto, quais serão os softwares que as empresas (a contratada e a contratante) deverão utilizar para garantirem a interoperabilidade, quem serão os responsáveis de cada etapa e de cada disciplina, quais os processos que deverão ser seguidos, dentre outras questões específicas e únicas para aquele projeto. A equipe conta que o momento de o desenvolver é após a contratação da empresa, porque ele deve ser feito em conjunto com a contratada, tratando-se de um acordo entre as partes. O profissional descreve essa etapa como importante para a troca de experiências e informação, visto que as organizações sempre possuem níveis de maturidade diferentes em relação ao BIM, portanto, em alguns momentos não adianta a contratante impor uma solução, porque, as vezes, a contratada possui outra melhor que poderia oferecer e agregar ainda mais ao projeto.

Para o piloto, a Empresa 1 criou um mecanismo de comunicação com a projetista contratada, sendo feita utilizando o padrão BCF, conforme se pode ver na Figura 24. O gerente da área conta que adaptaram o padrão para que a comunicação fosse recebida e enviada de uma maneira que fosse possível conectar os comentários com a sua disciplina, natureza, componente, desenho e local específico do modelo que está sendo validado. Todas as revisões seguem, dessa forma, com comentários e respostas do projetista. Assim é possível fazer um acompanhamento das solicitações realizadas e identificar quais foram as soluções específicas para determinada incompatibilidade. A necessidade da padronização da análise pelos colaboradores da contratante também é essencial, para que quando uma pessoa determinada não esteja presente, o próximo possa entender as revisões já feitas e prosseguir normalmente com o trabalho, conforme explica a equipe. 
Figura 24 - Exemplo de análise utilizando o padrão BCF

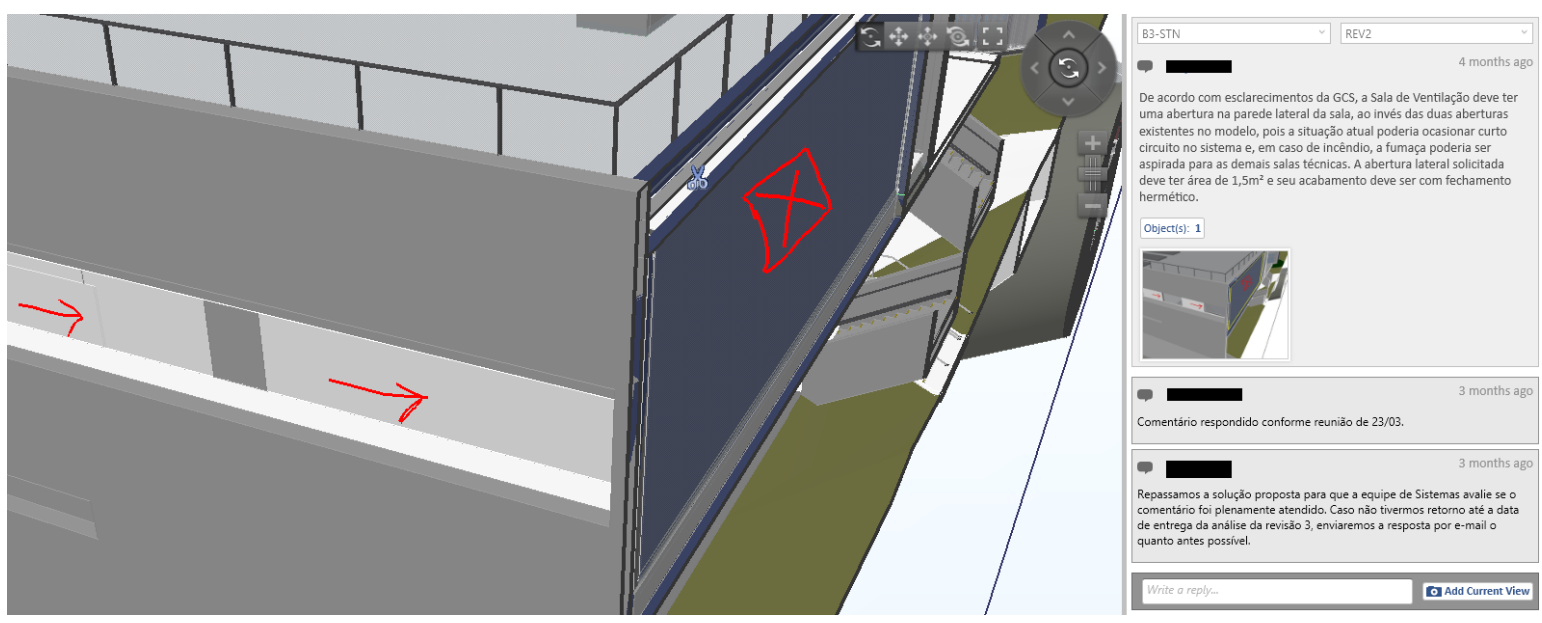

Fonte: Fornecido pela Empresa 1 (2018)

O entrevistado relata que existe até hoje resistência quanto à utilização do BIM na gerência e, por causa disso, além de precisar preparar o colaborador tecnicamente nas ferramentas, também é necessário convencê-los quanto às melhorias que a utilização das ferramentas BIM pode trazer para o dia a dia dele. $\mathrm{O}$ preparo desses colaboradores que ainda não tiveram contato com o BIM é feito por um processo totalmente interno, visto que a Empresa 1 não possui verba para a contratação de treinamentos externos, conforme relata o gerente.

O próprio responsável pela área prepara os treinamentos tanto teóricos quanto práticos e repassa para a equipe em reuniões. Após esses momentos, os colaboradores precisam desenvolver exercícios referentes à utilização para praticarem e trazerem dúvidas nos próximos treinamentos. Em relação aos investimentos, ele conta também que a empresa ainda não investiu em hardware para a compra de novos computadores e a questão dos softwares só foi possível pelo fato da empresa já possuir o pacote da Autodesk.

O BIM na GPR se resume, então, com relação à aplicação do método nos projetos básicos da Empresa 1, um processo que nasceu em 2013 e vem amadurecendo desde então. Nenhum projeto básico que nasceu em BIM chegou para a fase de projeto executivo até o momento, portanto os profissionais não podem afirmar como seguirá nesta etapa. Além da GPR, a área de obras da Empresa 1 também solicita que se utilize o método BIM, mas de uma maneira muito superficial, constando nos contratos deles apenas a frase "Preferencialmente em BIM". Durante as entrevistas não foi possível ter mais informações sobre esse setor, 
mas os profissionais entrevistados informaram que ainda não existe um processo formado para a utilização do BIM em outras áreas da empresa.

A empresa ainda não conseguiu obter resultados que demonstrassem as melhorias do projeto quando se utiliza o BIM, pela falta de projetos e continuidade deles. Após o projeto básico, a área do projeto executivo ainda não está trabalhando em BIM e a de obras também não. Apesar disso, o profissional acredita que o primeiro projeto básico que desenvolveram (conforme se pode ver na Figura 25) terá ganhos muito grandes quando chegar na fase de projeto executivo, no qual encontrarão um número menor de pontos a resolver, facilitando o refinamento e o detalhamento do que foi entregue.

O profissional relata também os próximos passos da área e o mapeamento das informações mínimas necessárias no projeto de cada disciplina, para então poder alinhar as suas expectativas com o que será solicitado para a contratada; a padronização de objetos BIM específicos da Empresa 1, para então disponibilizar para os projetistas utilizarem e entregarem o projeto da maneira esperada; definir as diretrizes para cronograma; revisar o modo de pagamento e contratação, para que seja possível adequar os contratos a nova forma de trabalho; desenvolver a exigência na licitação; aprimorar o manual de diretrizes BIM interno e avançar no uso da extração de quantitativos do modelo.

Figura 25 - Primeiro projeto básico que desenvolveram

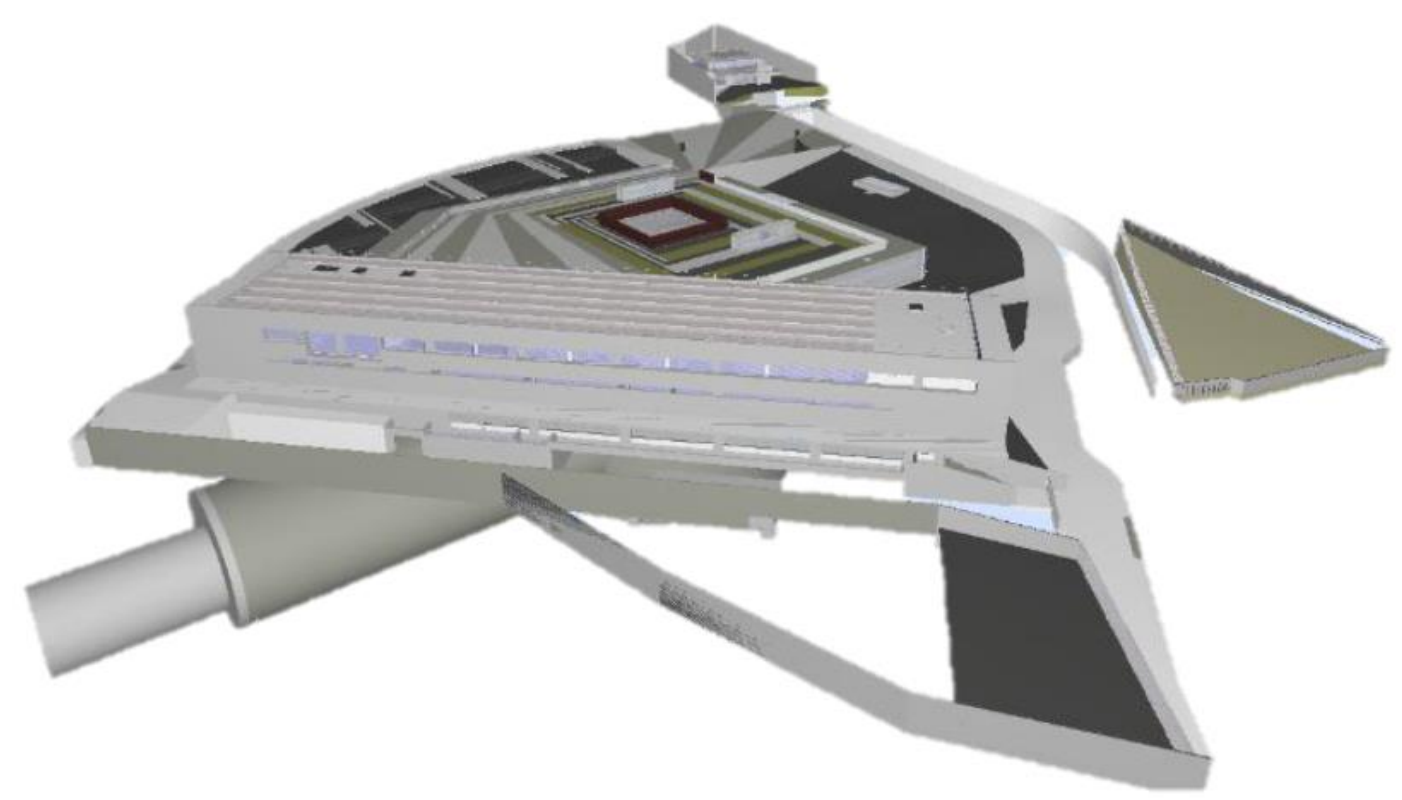

Fonte: Fornecido pela Empresa 1 (2019) 


\subsubsection{Inovação BIM}

Os profissionais entrevistados contam que o atual presidente da Empresa 1, ao assumir o cargo, apresentou o novo Plano de Negócios do governo, composto por diversos projetos, entre eles o projeto da adoção corporativa do BIM na Empresa 1 em todos os processos de projeto, construção e gestão dos ativos da companhia. O projeto do Inovação BIM então ficou responsável por conduzir essa implantação nas áreas, definir o plano de implantação, acompanhar essa implantação, organizar o fluxo de informações e dar suporte às áreas.

O primeiro passo para essa iniciativa foi montar um comitê em 2016 dividido em duas partes, a parte principal comporta por dois coordenadores e sete representantes, um de cada diretoria e a parte secundária composta por mediadores e integradores. Para identificar os mediadores e integradores foi feita uma análise do organograma da empresa para verificar quais as áreas são mais ou menos impactadas pelo BIM e, a partir desse momento, foram selecionados os facilitadores, que são aqueles que possuem o conhecimento do dia a dia operacional daquela área, e os mediadores, que são colaboradores da gerência em cargos focados em gestão, somando, assim, 122 pessoas das áreas mapeadas na Figura 26.

Figura 26 - Áreas envolvidas da Empresa 1
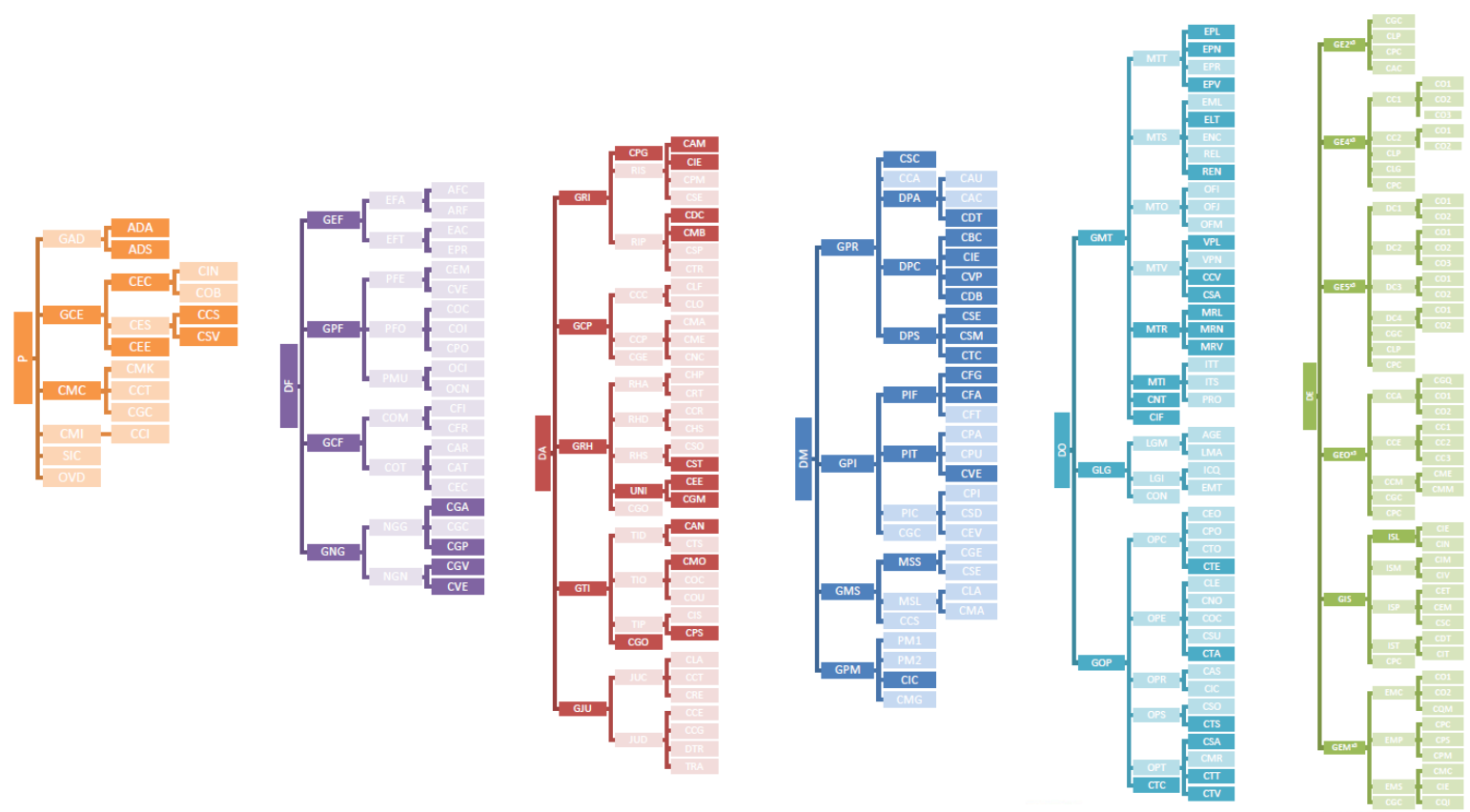

Fonte: Fornecido pela Empresa 1 (2018) 
Ainda em 2016, o profissional conta que a empresa foi convidada pelo SINDUSCON para dar uma palestra sobre o BIM, na qual decidiram explanar a filosofia de que o BIM é sobre pessoas e não só tecnologia, sendo que enquanto não for feito o BIM nas pessoas, podem existir diversos softwares, procedimentos, treinamentos, mas ninguém vai usar. Diante disso, o gerente conta que a empresa adotou uma postura de transformação dos colaboradores para que eles absorvessem o BIM e, posteriormente, fizessem a mudança e a implantação do BIM nas suas respectivas áreas, com o suporte desse comitê de Inovação BIM. Isso significa que no processo de adoção do BIM na empresa, cada área terá o seu investimento e o seu próprio planejamento para realizar essa implantação, com uma certa liberdade para escolher treinamentos, softwares, fluxos e processos.

O lançamento do projeto do Inovação BIM foi em um fórum organizado pelo comitê chamado de Nivelamento do Conhecimento, que reuniu vários profissionais de diferentes áreas que atuam com o BIM para palestrarem para os colaboradores da empresa, introduzindo o tema. Essa primeira iniciativa começou em 2017 e durou 20 semanas, sendo um dia por semana com duas ou três palestras, somando 52 palestras no total e 47 palestrantes convidados, envolvendo a participação de 254 funcionários em 1681 participações, que totalizaram 5.638 h/h de treinamento sem custo nenhum para a Empresa 1.

Alguns dos temas abordados foram colaboração, disciplinas, fundamentos, tecnologia, pessoas, padrões, estratégia, gestão de riscos, controle de planejamento, interoperabilidade, processos, ferramentas, gestão, manutenção, simulação, contratos, dentre outras temáticas. A variedade de assuntos e palestrantes ocorreu para que os colaboradores conseguissem ver o valor do BIM na sua área de atuação ou em algo semelhante. Portanto, o objetivo foi o de influenciar as diferentes áreas da empresa. O profissional relata que essa iniciativa foi muito impactante para o conhecimento dos colaboradores da organização e que essa iniciativa é sempre lembrada pela importância que teve.

O profissional entrevistado ressalta, ainda, a necessidade de gerar indicadores em todos os projetos realizados dentro da empresa para mostrar valor para a Diretoria. Para esse projeto do Nivelamento do Conhecimento, então, decidiram criar alguns gráficos para a medição da evolução da maturidade BIM antes e depois das palestras. Dentre aquelas 122 pessoas que foram escolhidas para serem os integradores e mediadores do projeto, 87 pessoas responderam à 
primeira pesquisa realizada antes das palestras e 72 à segunda realizada após. A pesquisa compreendeu 7 perguntas e a Empresa 1 obteve as respostas que constam nos Gráficos 8, 9, 10.

1) Dentre as opções apresentadas, qual é a que melhor define o que é BIM para você? - Respostas pré-definidas.

\section{Gráfico 8 - Respostas da Pergunta 1}

\section{O que é BIM ?}

É desenvolver projetos em três dimensões (3D), permitindo a união destes projetos e uma verificação mais detalhada

É um conjunto de programas de computador (softwares) que permitem o desenvolvimento de projetos com maior detalhamento

É um processo que acompanha desde o planejamento até a operação e manutenção de instalações civis

É um modo de colaboração entre todos os envolvidos, resultando em um projeto melhor definido

Nenhuma das opções anteriores

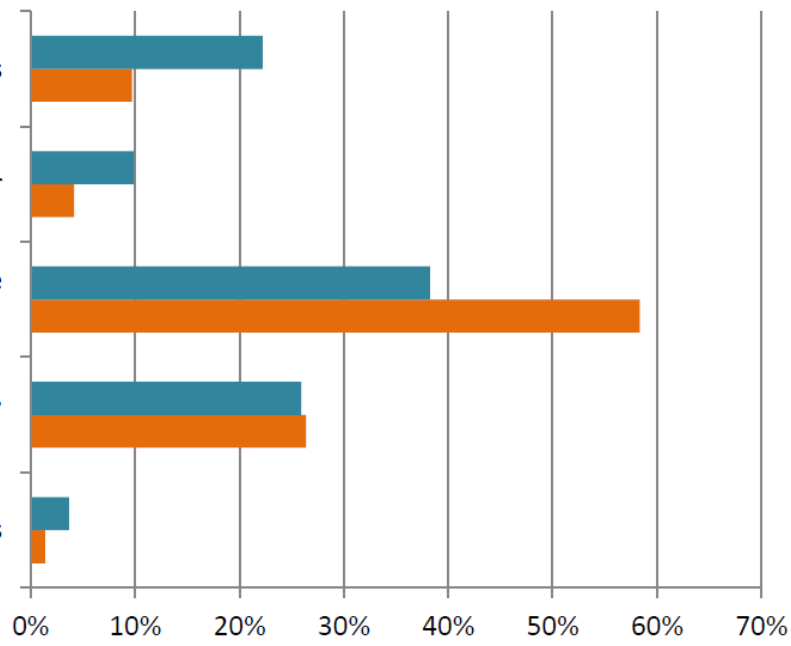

nesquisa 01 Pesquisa 02

Fonte: Fornecido pela Empresa 1 (2019)

2) Você tem clareza da sua participação nesse projeto? - Respostas a partir da escala Likert.

Gráfico 9 - Respostas da Pergunta 2

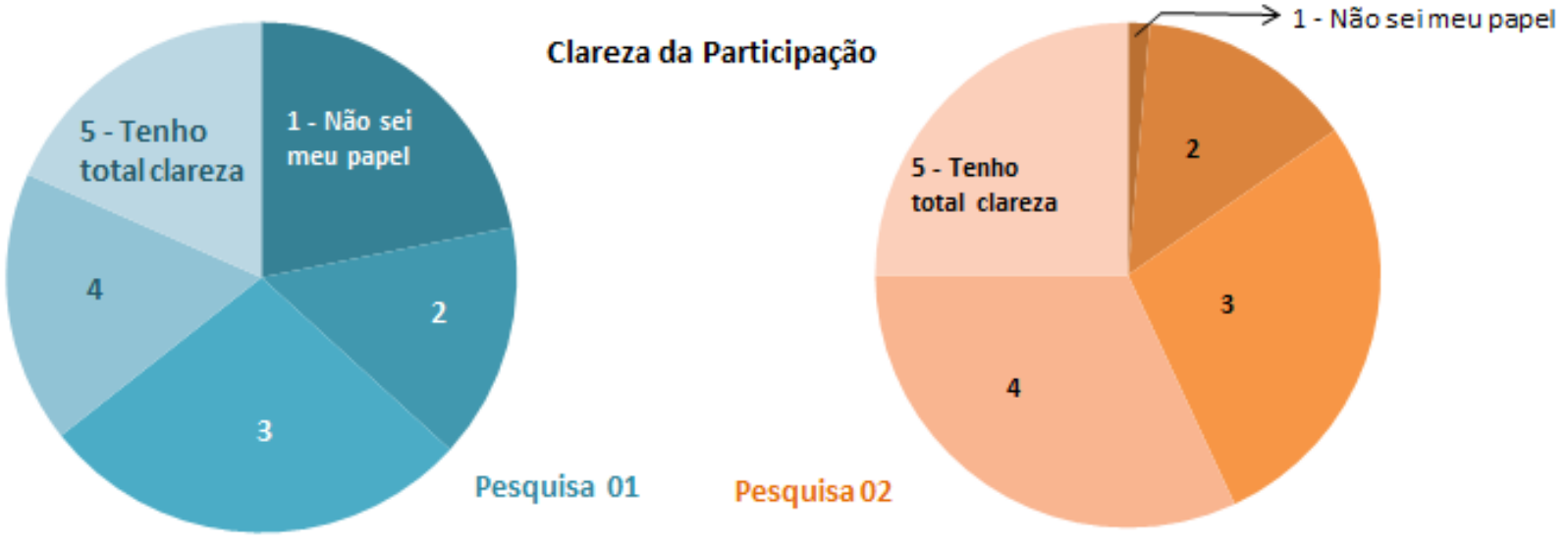

Fonte: Fornecido pela Empresa 1 (2019) 
3) 14 perguntas em Escala Likert referentes aos itens ligados às melhorias que podem ser alcançadas com a adoção do BIM.

Gráfico 10 - Respostas da Pergunta 3

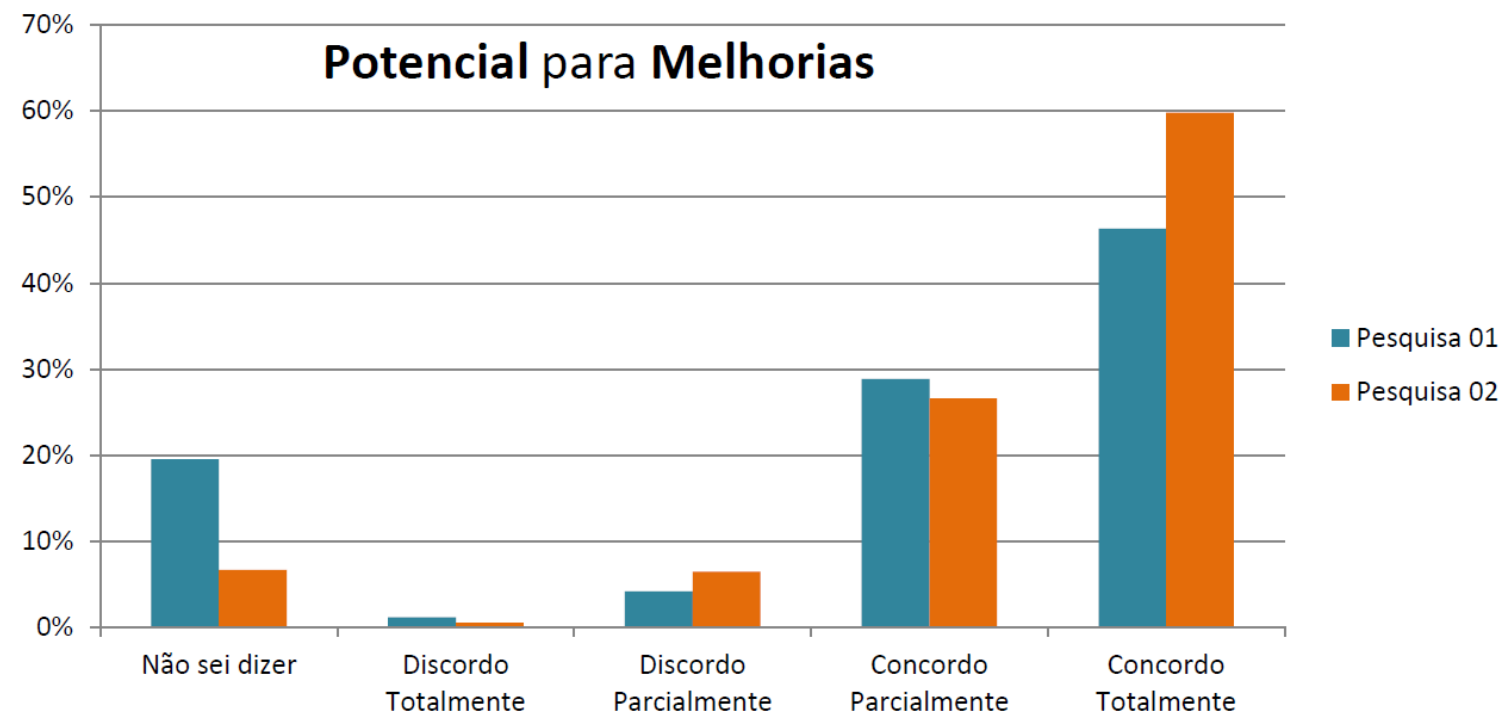

Fonte: Fornecido pela Empresa 1 (2019)

4) BIM na Empresa 1 - Aplicações, Impactos e Melhorias. Essa pergunta tratou do futuro da utilização do BIM na companhia - Respostas a partir da escala Likert.

Gráfico 11 - Respostas da Pergunta 4

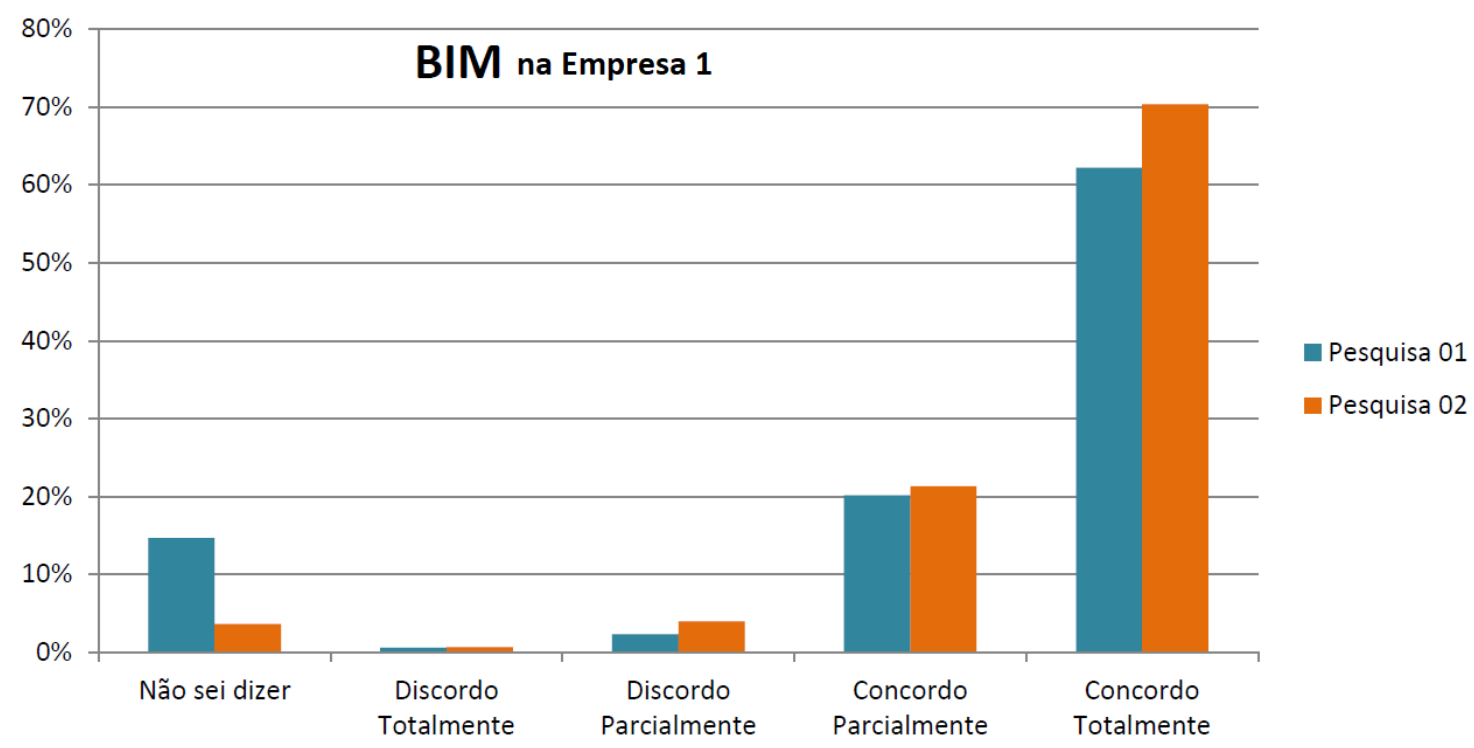

Fonte: Fornecido pela Empresa 1 (2019) 
5) O BIM deve ser implantado nos projetos da Empresa 1? - Respostas a partir da escala Likert

Gráfico 12 - Respostas da Pergunta 4.1

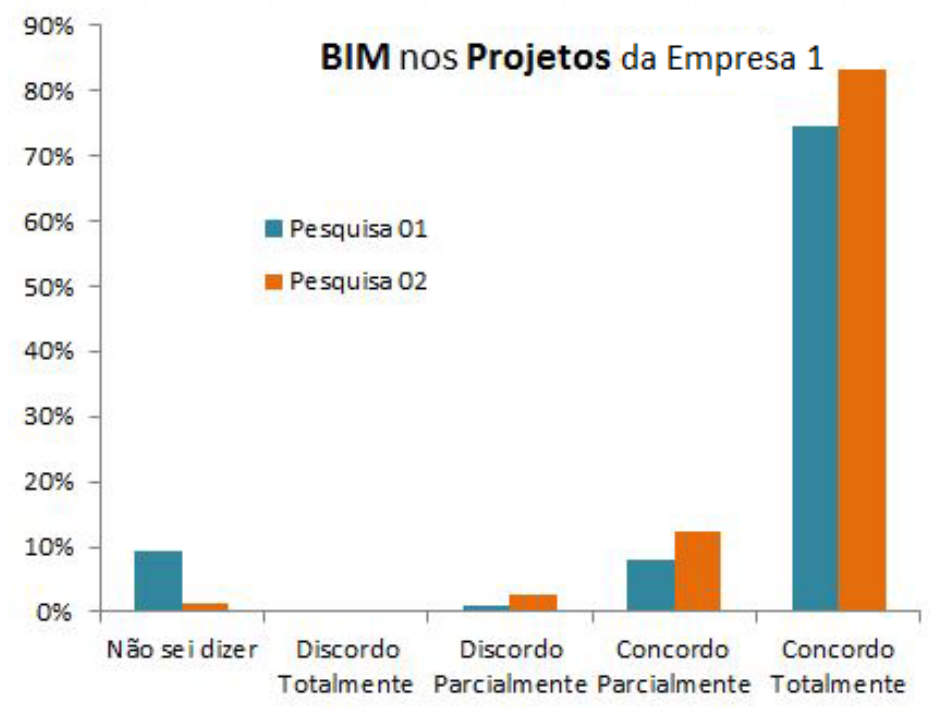

Fonte: Fornecido pela Empresa 1 (2019)

6) O BIM deve ser implantado em todas em todas as áreas da companhia envolvidas nesses projetos? - Respostas a partir da escala Likert.

Gráfico 13 - Respostas da Pergunta 4.2

BIM em Todas as Áreas Envolvidas

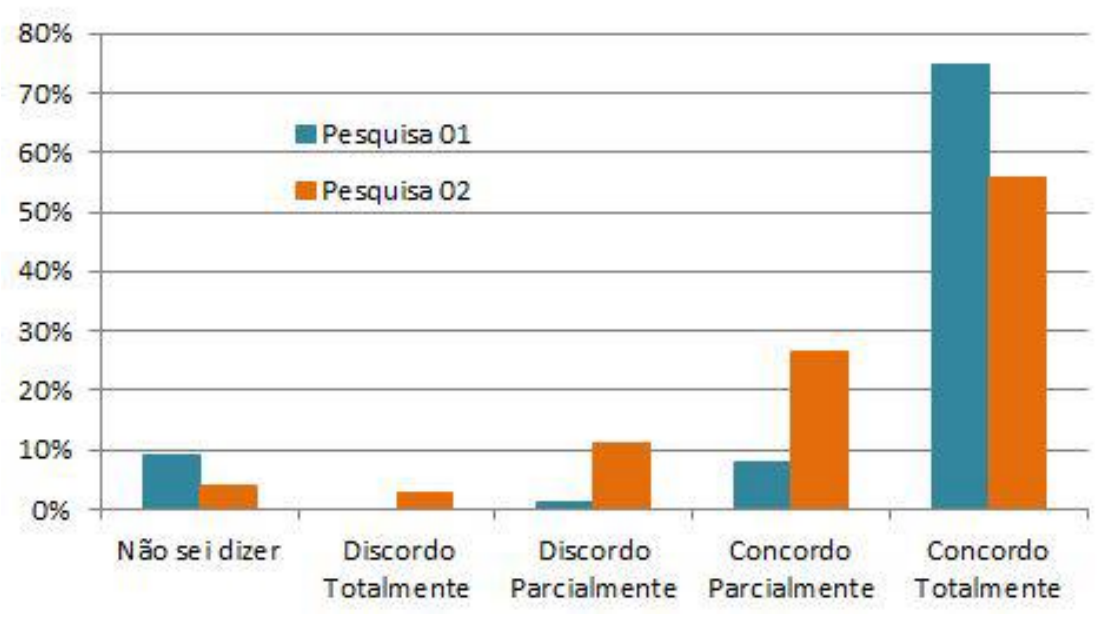

Fonte: Fornecido pela Empresa 1 (2019) 
7) Qual é o seu nível de conhecimento sobre os Termos Relacionados ao BIM? Gráfico 14 - Respostas da Pergunta 5

IFC - Industry Foundation Classes

LoD - Level of Detail

Lol - Level of Information

COBie

ABNT NBR 15965

BuildingSmart

Parametrização

BCF - BIM Collaboration Format

PEB - Plano de execução BIM

MAN 10-203 - Manual de Diretrizes BIM

CIM - City Information Modeling

CAD - Computer Aided Design

CFD - Computational Fluid Dynamics

CAFM - Computer-Aided Facility Management

MVD - Model View Definition

IOT - Internet of Things

Laser Scanning

GIS / SIG - Sistema de Informação Geográfica

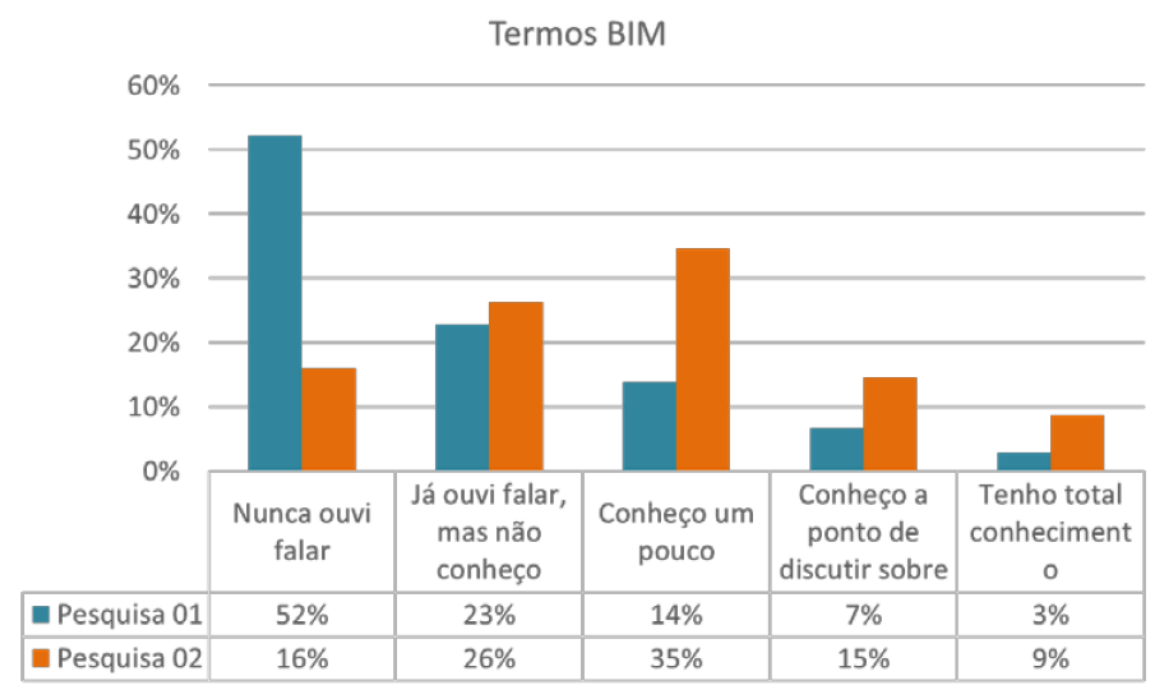

Fonte: Fornecido pela Empresa 1 (2019)

O responsável pelo projeto de implantação do BIM na empresa analisa que as respostas associadas aos projetos em 3D e o conjunto de ferramentas BIM tiveram um número maior na primeira pesquisa, enquanto na segunda as respostas foram transferidas para o entendimento do BIM como processo. Isso demonstra um avanço na maturidade do conhecimento sobre o método, já que o BIM passa a ser visto de modo mais completo, superando visões parciais de apenas alguns dos seus aspectos. Essa informação pode ser vista nas respostas da pergunta 1 no Gráfico 14. Sobre a segunda questão, ele indica que a percepção dos colaboradores quanto a sua atuação no processo de transformação da empresa aumentou após a rodada de palestras, enquanto os profissionais começaram a entender melhor o seu papel nesse processo, como pode ser visto no Gráfico 14.

A pergunta 3 abordou o conhecimento da capacidade do método BIM, reunindo 14 melhorias que podem ser alcançadas com a adoção do BIM, para entender a visão dos colaboradores sobre essa capacidade. Alguns temas abordados foram relacionados à gestão de informações e de bens, colaboração e integração, além de ganhos associados à qualidade, ao custo, ao prazo e à sustentabilidade. O entrevistado destaca que depois do nivelamento de conhecimento, a capacidade de avaliar os benefícios do BIM aumentou 
consideravelmente entre os que responderam. Além disso, a grande maioria dos participantes concorda que o BIM oferece as melhorias.

A pergunta seguinte tratou da opinião dos colaboradores sobre o futuro da utilização do BIM na companhia, além dos seus impactos e melhorias ligadas aos aspectos específicos da empresa. O gráfico 14 apresenta o resultado geral dos oito itens pesquisados, mostrando a concordância dos colaboradores de que o BIM seja aplicado na empresa, bem como em que sua adoção traz melhorias e impacta em mudanças nos processos atuais das respectivas áreas de trabalho.

Ainda no sentido da adoção do BIM na empresa, o profissional relata que as perguntas 4.1 e 4.2 foram relacionadas também com a utilização do BIM. A 4.1 questiona se os colaboradores concordam que o BIM deverá ser utilizado em todos os projetos da empresa. Pelas respostas é possível perceber que o percentual de participantes que concordam que o Metrô deve utilizar o BIM nos seus projetos aumentou na segunda pesquisa, de maneira a atingir praticamente 100\%. Já na 4.2 reduziu o percentual de profissionais que concordam totalmente com a frase "O BIM deve ser aplicado em todas as áreas da companhia envolvida neste projeto", enquanto a parcela dos que concordam parcialmente aumentou. O profissional responsável pelo projeto "Inovação BIM" analisa que esses dois fatos associados indicam que após as palestras, os colaboradores possuem maior noção de que apesar da Empresa 1 utilizar o BIM nos seus projetos, é importante que cada área examine de modo aprofundado quais são as aplicações do BIM para as suas atividades, demonstrando, assim, maior maturidade em relação ao tema.

Por fim, a última pergunta mensurou o nível de conhecimento dos colaboradores sobre os termos técnicos relacionados ao BIM. Para o entrevistado, os resultados mostram de forma nítida a mudança da predominância do desconhecimento ("nunca ouvi falar") para um estágio intermediário ("conheço um pouco"). Esse fórum teve o objetivo de preparar os colaboradores para as próximas etapas de adoção do BIM que virão, porque, dessa maneira, os colaboradores poderão ter uma visão de como o BIM poderá auxiliar nas suas atividades diárias e nos seus projetos.

Como o comitê é restrito no seu tamanho, eles precisavam de ajuda para identificarem como o BIM seria utilizado em cada área. Então, para descobrir essa usabilidade decidiram reunir os profissionais que participaram das palestras para eles indicarem as melhorias que eles viam hoje, sendo necessárias nas suas 
respectivas áreas, para, posteriormente, tentarem relacionar com o que o BIM tem a oferecer e então conseguirem identificar os usos do BIM para cada área da empresa. A empresa contratou o SENAI para desenvolverem esse workshop com os colaboradores, mas o profissional conta que apesar da ideia fazer sentido para a identificação dos usos, a experiencia não deu o resultado esperado. O profissional conta que alguns motivos para isso foram: o momento do desenvolvimento do workshop que se sobrepôs a uma mudança de um sistema da empresa, no qual todas as equipes estavam focadas nessa alteração e a falta da definição do cenário e da escala, o que resultou em ideias muito vagas e fora do contexto buscado. A consequência dessas dificuldades foi o atraso na definição dos objetivos BIM da organização, porque os insumos que vieram dessa experiência impossibilitaram a ligação entre as necessidades das áreas e as possibilidades do BIM.

O entrevistado conta que em 2017 a ideia do comitê é a de definir os objetivos para a empresa na fase 1, tendo uma cronologia, tempo para maturidade e orçamento até que seja possível a empresa estar preparada para dar andamento para as próximas etapas e os novos objetivos. Essas fases terão que ser aprovadas pela diretoria, para que após a definição e o desenho da implantação, comece a ação da implementação específica. Os faseamentos e os planos de investimento para cada fase serão parte de um plano de implantação maior, que também prevê o desenvolvimento de um caderno BIM, que consistirá em vários documentos da empresa, indicando como tecnicamente trabalhar com o BIM para a padronização do uso na Empresa 1 e o cronograma de alcance de maturidade e de implantação. Ele entende que esse é um plano para mais de 10 anos, se considerar todas as fases, as implantações e os períodos de amadurecimento. A Estrutura Analítica do Projeto de adoção do BIM foi totalmente mapeada na Figura 27. A Empresa 1 pretende desenvolver cada uma dessas etapas para a adoção completa na organização. 
Figura 27 - Estrutura Analítica do Projeto

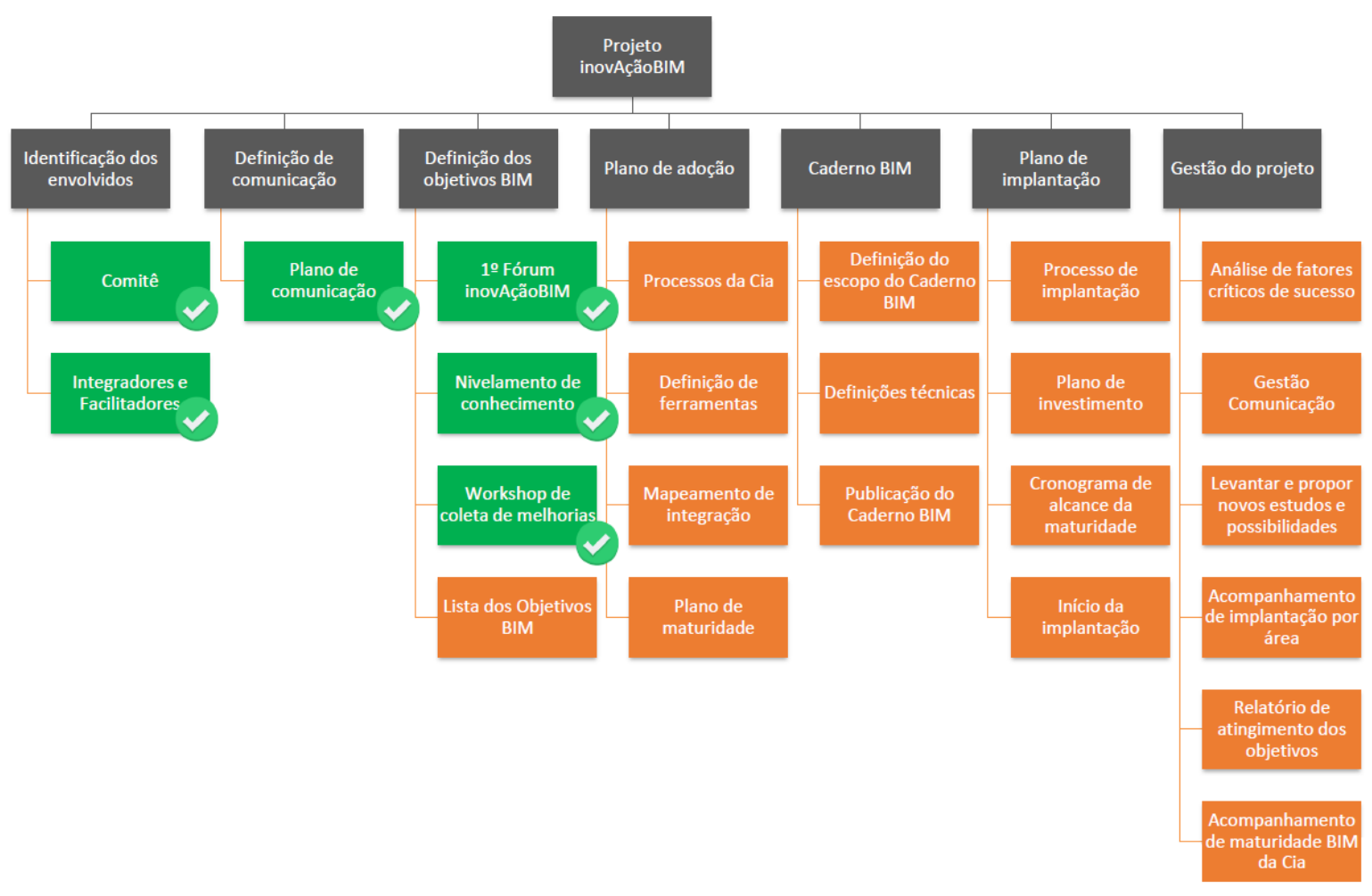

Fonte: Empresa 1 (2019)

Em 2018 os objetivos da fase 1 foram definidos. O primeiro deles é assegurar a confiabilidade, a rastreabilidade, a segurança, o acesso as informações de projeto, a execução, a operação, a manutenção e a demolição dos ativos. As ações para alcançar esse objetivo são adotar práticas de gestão da informação por intermédio do uso do BIM, aumentar a eficiência dos processos correlatos com integração de informações e dados geoespaciais, garantir acesso às informações georreferenciadas para subsidiar a tomada de decisão, aprimorar os processos referentes à execução das atividades de manutenção, implantar ambiente comum de dados para coleta e compartilhamento de informações, adotar os processos de emissão e aprovação de documentos em formato digital, reduzir a perda de informações durante todo ciclo de vida e promover o trabalho colaborativo.

O profissional entrevistado conta que outro objetivo definido para a fase 1 é contribuir para a sustentabilidade financeira da empresa. Para atingir esse objetivo será necessário otimizar atividades de manutenção, reduzir prazos de custo de implantação do empreendimento, aperfeiçoar processos de treinamento, aprimorar a gestão de ativos e a aprovação dos projetos. O terceiro objetivo é o de potencializar a prospecção e a gestão de negócios. Sendo assim, a empresa terá 
que integrar as informações sobre espaços e mapear potenciais usos para novos negócios, melhorar a visualização e a análise de espaços para a comercialização, criar oportunidades de negócio como prestação de serviço e atividades de consultoria. Um exemplo que o entrevistado cita e que já ocorreu concerne à procura por treinamento BIM na Empresa 1 por organizações de projetos para entenderem como deve ser feito o projeto BIM para a Empresa 1 e assim estarem prontos para quando tiver uma licitação.

O quarto objetivo também segue na mesma linha dos demais, conforme relata o profissional, que é o de aumentar a eficácia das soluções de projeto. Para essa necessidade o comitê entende que é preciso dar suporte para melhorar a colaboração interna e externa da companhia durante o ciclo de vida do empreendimento; subsidiar o desenvolvimento e a análise de cenários, bem como a definição de estratégia para a manutenção da segurança operacional; subsidiar obtenção de alvarás, licenças junto aos órgãos externos; subsidiar a gestão do processo de um projeto em todas as etapas do ciclo; dar suporte à análise e viabilidade técnica, econômica, implantação, adequação e modernização; dar suporte aos processos relacionados à segurança do trabalho; desenvolver diretrizes para a contratação e a gestão de produtos e serviços com BIM; aumentar a precisão dos quantitativos para a elaboração de orçamento; aumentar a integração entre as disciplinas de projeto; dar suporte às funções de projeto, considerando o custo de operação, manutenção do empreendimento; subsidiar tomadas de decisão com base no estudo de viabilidade econômica e financeira para a expansão da rede. Todos esses objetivos e ações mapeadas para cada um deles foram apenas definidas, mas ainda é necessário entender como será feita cada uma dessas ações, o que é relatado pelo profissional.

Os próximos passos do comitê na empresa são contribuir com a sustentabilidade da organização, otimizando as atividades de manutenção, reduzindo prazos e custos para a implantação de empreendimentos, aperfeiçoando os processos de treinamento, aprimorando a gestão de ativos e apoiando o gerenciamento de projetos, tudo isso com BIM. Também já está sendo feito o mapeamento dos possíveis usos do BIM, identificando-se 83 usos. Agora a organização está classificando o nível de maturidade BIM para poder adotar aquele uso e quais áreas poderiam se beneficiar daqueles usos específicos. A partir disso será possível separar todas as utilizações de nível 1 e quais são as áreas que 
poderão adotar aqueles usos, o que será o foco do trabalho do comitê, conforme relata o profissional entrevistado. Esses níveis de maturidade definirão as fases de adoção do BIM na empresa, terão valores definidos para cada fase do projeto, o que deverá ser aprovado pela diretoria, terão metas e objetivos bem definidos e o tempo esperado para cada uma delas. Além disso, o comitê pretende repetir a pesquisa de maturidade todos os anos para acompanhar a evolução do BIM na empresa.

\subsection{EMPRESA 2}

A Empresa 2 é uma organização pública que administra o sistema ferroviário na Região Metropolitana de São Paulo, atendendo a 23 municípios. Fundada em 1992, é responsável pelo planejamento, projeto, construção, operação e manutenção de 94 estações e, aproximadamente, 273 quilômetros de trilhos.

As entrevistas foram conduzidas nessa empresa com quatro profissionais diferentes da Diretoria de Planejamento e Projetos que realiza os projetos e o planejamento de novas linhas e o projeto das reformas das edificações existentes, sendo uma arquiteta que atua na gestão dos projetos da empresa e o coordenador da área de implantação do BIM na organização. O estudo de caso englobou também a análise dos documentos fornecidos pelos profissionais.

A empresa possui uma hierarquia tradicional, com a Presidência, quatro diretorias, sendo elas Administrativa e Financeira, Operação e Manutenção, Engenharia e Obras e Planejamento e Projetos e gerências divididas em departamentos, conforme Figura 28 abaixo. 
Figura 28 - Organograma Simplificado da Empresa 2

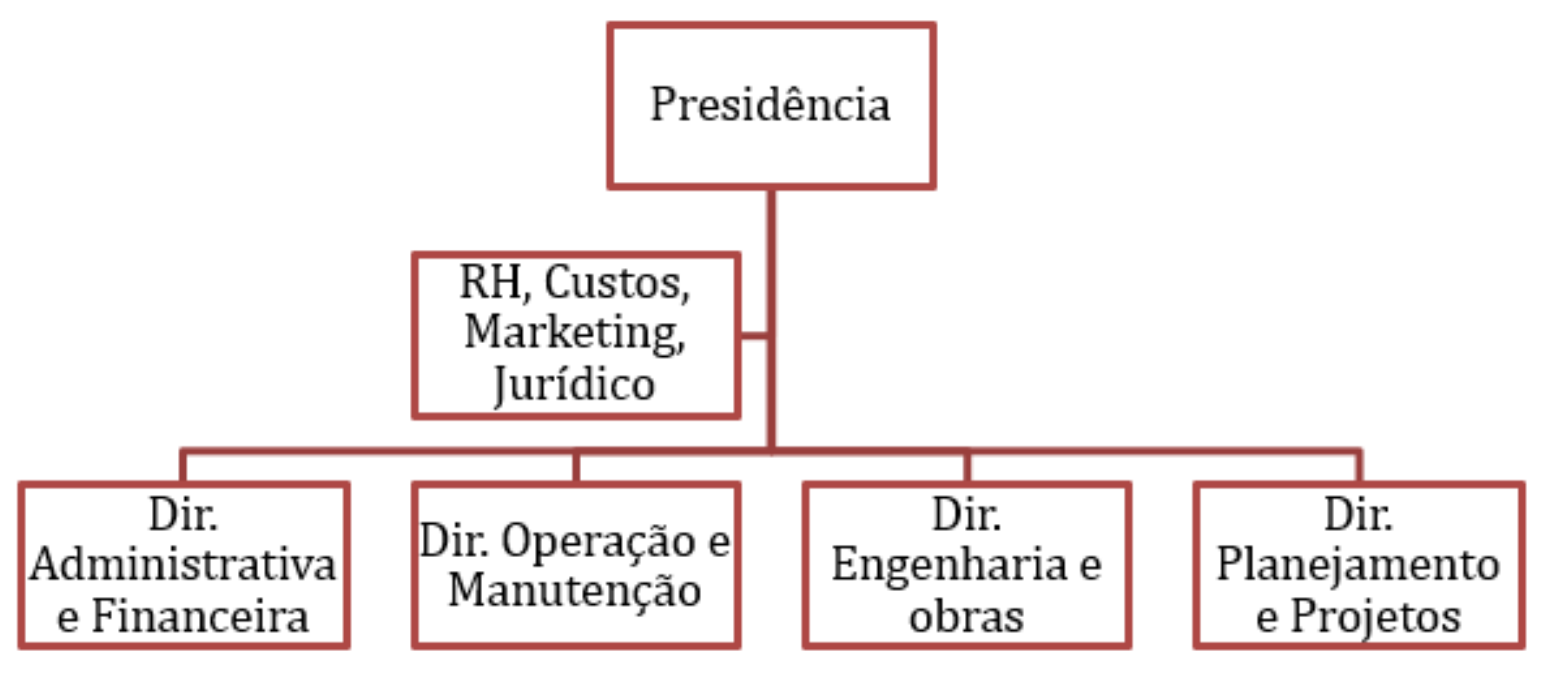

Fonte: A autora (2019)

A profissional entrevistada conta que por ser uma empresa pública, os problemas referentes ao custo gerado por aditivos contratuais e tempo de construção causados por imprevistos representam um impacto muito grande nos gastos públicos. Esses problemas são resultados de erros nos projetos decorridos da ausência de padronização e acompanhamento, bem como a má compatibilização deles, gerando, assim, retrabalhos e atrasos nas fases seguintes de construção e até mesmo operação.

Os profissionais relataram que em 2012 a Diretoria de Planejamento e Projetos da Empresa 2 solicitou que um dos seus assessores começasse a estudar sobre o método BIM, devido à necessidade de melhorar os processos e a integração entre projeto e obra e, ainda, aumentar a qualidade dos projetos. Durante esse período de conhecimento, a Empresa 2 já decidiu inserir a questão da necessidade dos projetos serem em BIM nas licitações das reformas das estações existentes para a adequação à norma de acessibilidade. Incluíram então no contrato a seguinte informação "o projeto deverá ser elaborado na plataforma BIM, em formato IFC (número da versão)". Isso foi realizado porque os profissionais da área ainda não possuíam conhecimentos específicos para solicitarem nada diferente disso. Apesar da inclusão dessa cláusula nos documentos de contratação, a forma de medição para o pagamento não foi revisada e se manteve como pagamento pelo preço global por projeto apresentado em pranchas. 
A Empresa 2 possui uma forte responsabilidade social e está engajada com o tema de acessibilidade nas suas estações, trabalhando para adequar as suas dependências às normas vigentes de acessibilidade. São 66 das 94 estações que já possuem condições de acesso às pessoas com restrição de mobilidade. $O$ objetivo da empresa é o de adequar com a norma de acessibilidade todas as estações existentes e as novas até 2022. Essas reformas que estão sendo realizadas são para garantirem o atendimento à norma de acessibilidade, nas quais são previstas plataformas totalmente cobertas, sanitários adaptados, mapas em braile, escadas rolantes e itens de acessibilidade, como elevadores, rampas, corrimãos, pisos e rotas táteis.

Algumas licitações foram então lançadas ao mercado, porém, por motivos de programação orçamentária da Empresa 2, acabaram não sendo contratados e foram interrompidos desde 2013. Mesmo sem projetos para praticar a utilização das ferramentas BIM, os profissionais da empresa continuaram pesquisando sobre o método e em 2014, durante a renovação das licenças do pacote da Autodesk, surgiu a oportunidade de contratar também uma consultoria que faria o processo de implantação do BIM na empresa, fornecendo treinamentos para os profissionais, conforme timeline da Figura 29.

Figura 29 - Timeline da implantação do BIM na Empresa

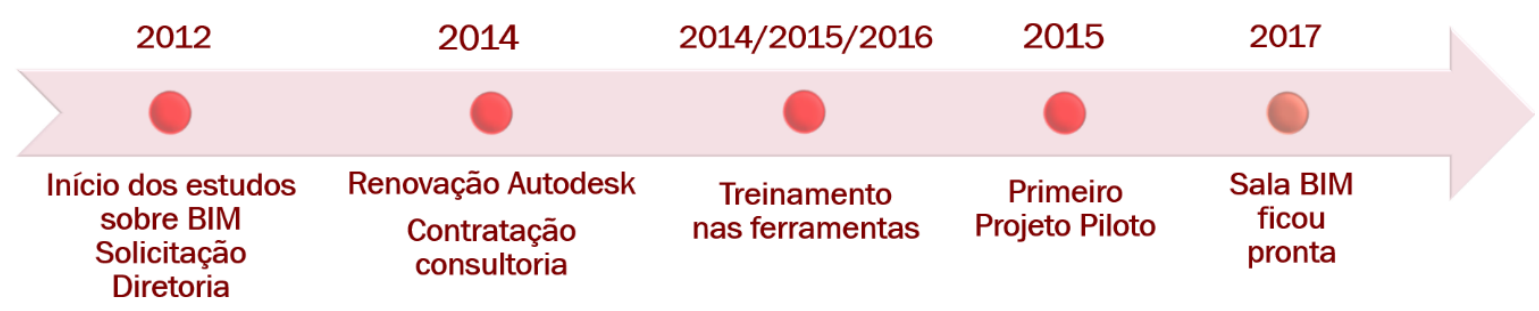

Fonte: A autora (2018)

Essa consultoria auxiliou na estratégia de adoção do BIM na empresa, definição dos softwares, treinamento nesses e orientação sobre hardwares. Os profissionais contam que os treinamentos foram obrigatórios, divididos em básicos e intermediários, e foram dados para alguns colaboradores em determinados softwares que Ihes seriam úteis nas suas rotinas, mas nem todos os colaboradores tiveram todos os treinamentos. Esse aprendizado ocorreu entre 2014, 2015 e 2016 nos softwares Infraworks, Revit, Navisworks e Civil 3D, mas após os treinamentos 
iniciais já foram selecionados pela Empresa 2 em conjunto com a consultoria, os projetos-pilotos, para que os profissionais aplicassem o que estava sendo treinado.

Como as licitações de adaptação à norma de acessibilidade haviam sido paralisadas, decidiram então aplicar o conhecimento adquirido nos projetos de duas estações que modelariam internamente. A profissional entrevistada conta que a Empresa 2 escolheu esses dois projetos porque, de acordo com a consultoria, um projeto-piloto deveria ter uma variedade de disciplinas e ser de pequeno porte, para então incluir a atuação de diversos profissionais e garantir um ambiente controlado para o projeto, no qual foi possível observar e diagnosticar problemas de processo recorrentes na empresa.

A profissional relata que ambas as estações escolhidas são tombadas e foram construídas há mais de 120 anos, portanto os projetos consistiram na adequação do entorno (calçadas, locais de estacionamento de automóveis e terminais de ônibus) e das áreas internas das construções existentes, como bilheterias, locais de embarque, sanitários públicos, corredores, dentre outros. Para esses projetos-pilotos foram utilizados o Revit para a modelagem do existente e das reformas a serem desenvolvidas, software Navisworks para a compatibilização dos projetos e o BIM 360 para a comunicação entre os envolvidos, a partir da inserção de comentários nos modelos.

Para iniciar os projetos foi necessário também realizar a atividade do levantamento da nuvem de pontos da estação existente para poderem então fazer a modelagem. Para isso foi empregada a tecnologia do laser scanning, que traz a geometria da construção com alta precisão, conforme se pode verificar na Figura 30. A estratégia proposta pela consultoria para a Empresa 2 começar a trabalhar com o BIM foi a criação de uma Sala BIM, mas como a Empresa 2 ainda não possuía os hardwares necessários, os participantes do projeto se deslocavam até a Sala BIM disponibilizada nas dependências da consultoria.

As disciplinas envolvidas nos projetos foram Arquitetura, Elétrica, Hidráulica, Sinalização e Comunicação visual. Portanto, foram selecionadas 10 pessoas entre arquitetos e engenheiros de diferentes áreas da empresa para comporem a equipe dentre aqueles que haviam recebido treinamento nos softwares, de acordo com a sua expertise nas disciplinas e vontade de participarem no projeto de inovação proposto pela Empresa 2. Um dos profissionais entrevistados conta que esse foi o momento quando a resistência à mudança foi mais presente durante esse 
desenvolvimento, porque os profissionais selecionados pensavam que eles já tinham coisas demais para fazer na área de origem deles e estavam recebendo ainda mais demanda, observando que ficariam mal vistos frente aos seus respectivos chefes; e os gerentes das áreas também se demonstraram resistentes por terem que ceder recursos humanos das suas áreas para realizarem outras atividades.

Figura 30 - Nuvem de pontos do laser scanning

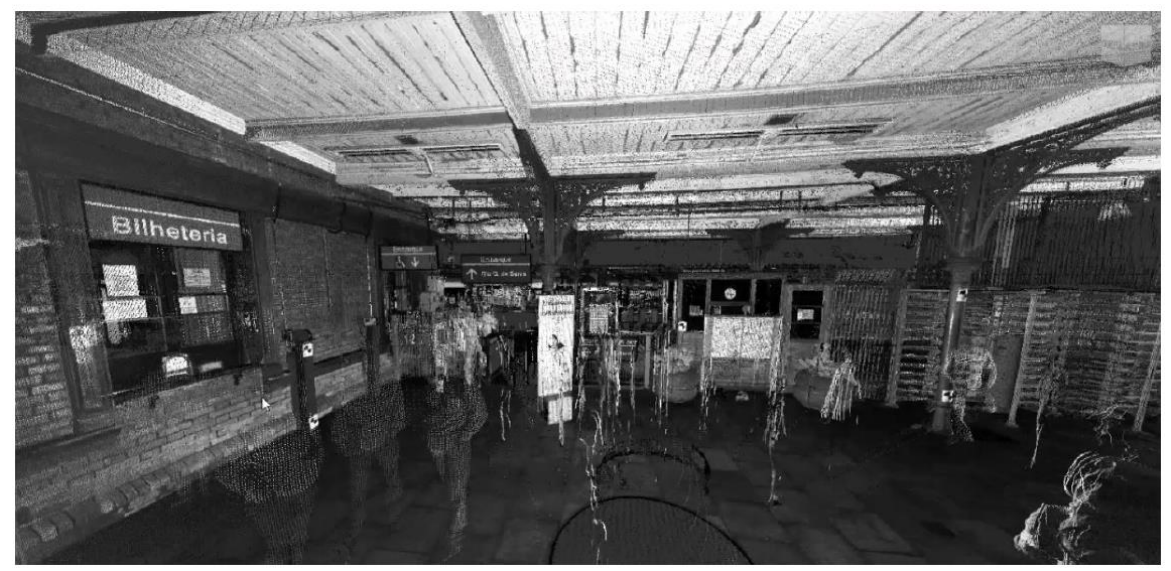

Fonte: Cavalcanti (2018)

Apesar dessa proposta da empresa de começar a utilizar o BIM, durante o desenvolvimento desse primeiro projeto, os profissionais que participaram não ficaram exclusivos nesse, pois atuavam apenas duas vezes por semana nele e nos outros dias se dedicavam às demandas das suas áreas de origem. Por essa questão da falta de exclusividade e todos os impasses antes de iniciar o processo de projeto, a profissional entrevistada conta que esse se estendeu por um ano, apesar da diretoria ter estipulado o prazo de 15 dias para que o processo estivesse pronto.

Durante o projeto havia um profissional de consultoria em tempo integral acompanhando e dando suporte ao desenvolvimento de todas as disciplinas e auxiliando com as dificuldades dos profissionais nas ferramentas que estavam sendo utilizadas. Os profissionais entendem que a alocação da equipe em uma sala diferente do ambiente em que costumavam trabalhar serviu para que eles tivessem maior foco naquele projeto em especifico, sem interrupções por colegas de trabalho, e pudessem ter uma comunicação mais rápida e assertiva por estarem focados no mesmo projeto e fisicamente na mesma sala. Para esse primeiro projeto não foi definido um responsável pela coordenação. 
Um dos profissionais conta que primeiro realizaram a modelagem da construção existente a partir da nuvem de pontos e, em seguida, modelaram as reformas que seriam feitas. Três anos antes do início desses projetos, havia sido feito um estudo referente ao que deveria sofrer alteração nas estações para se adaptarem à norma de acessibilidade, porém, nesse momento, se deram conta que esses estudos estavam desatualizados e tiveram que atualizá-los internamente antes de começarem a modelagem, o que gerou atrasos no cronograma de execução.

Outro ponto levantado pela arquiteta que impactou no prazo foi a falta de organização do cronograma referente à ociosidade de algumas disciplinas enquanto aguardavam a definição da arquitetura. Além disso, com a nuvem de pontos obtiveram a estrutura existente, mas não possuíam muitas informações sobre os sistemas de hidráulica e elétrica e os projetos existentes desses estavam desatualizados por terem sofrido diversas alterações ao longo dos anos. Portanto, nesse momento, houve a necessidade de realizar uma pesquisa in loco nas estações para identificar onde estavam localizados esses sistemas.

Realizaram, então, toda a modelagem da primeira estação, fizeram a verificação de interferência entre os projetos no Navisworks conforme se pode verificar na Figura 31, discutiram em reunião sobre as incompatibilidades e decidiram na equipe qual seria a solução de cada uma delas. $O$ coordenador conta que em alguns momentos houve a necessidade de consultar alguns profissionais mais experientes nas disciplinas, para discutir sobre as soluções construtivas, mas devido à distância entre a Sala BIM da consultoria e a sede da empresa isso não foi possível. A arquiteta entrevistada relata que as famílias desenvolvidas para a modelagem do projeto foram feitas pela equipe da consultoria. 
Figura 31 - Identificação de interferência pelo Navisworks

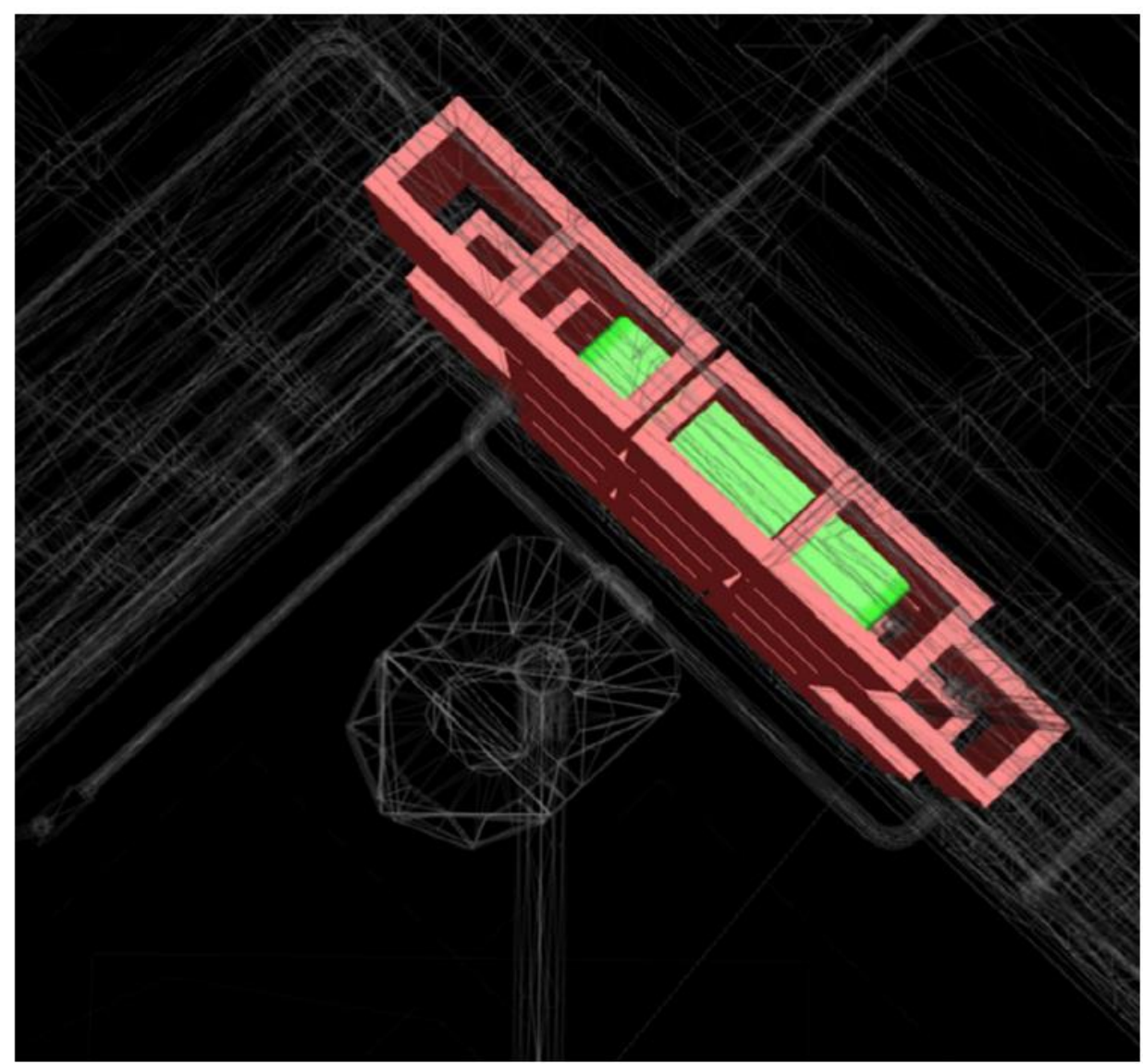

Fonte: Cavalcanti (2018)

Ao final da modelagem, com todas as soluções implantadas, apresentaram o modelo para as áreas de obras e operação em uma reunião. Durante esse primeiro encontro, as equipes das outras áreas levantaram diversas questões referentes à viabilidade de execução, dificuldade na operação e manutenção, dentre outras questões relevantes. Como o modelo já estava pronto, a arquiteta conta que esses pontos levantados pelas outras equipes geraram um grande desconforto no grupo que desenvolveu o projeto, visto que o modelo já havia sido realizado quando o apresentaram. Apesar do desconforto, a equipe BIM teve todo o retrabalho para realizar as modificações necessárias apontadas pelos colaboradores de obra e manutenção, gerando atrasos no cronograma. Levando em consideração o posicionamento dos profissionais das áreas parceiras, realizaram então as alterações acordadas entre todos, culminando nos modelos da Figura 32. 
Figura 32 - Situação atual x modelo - Bilheteria
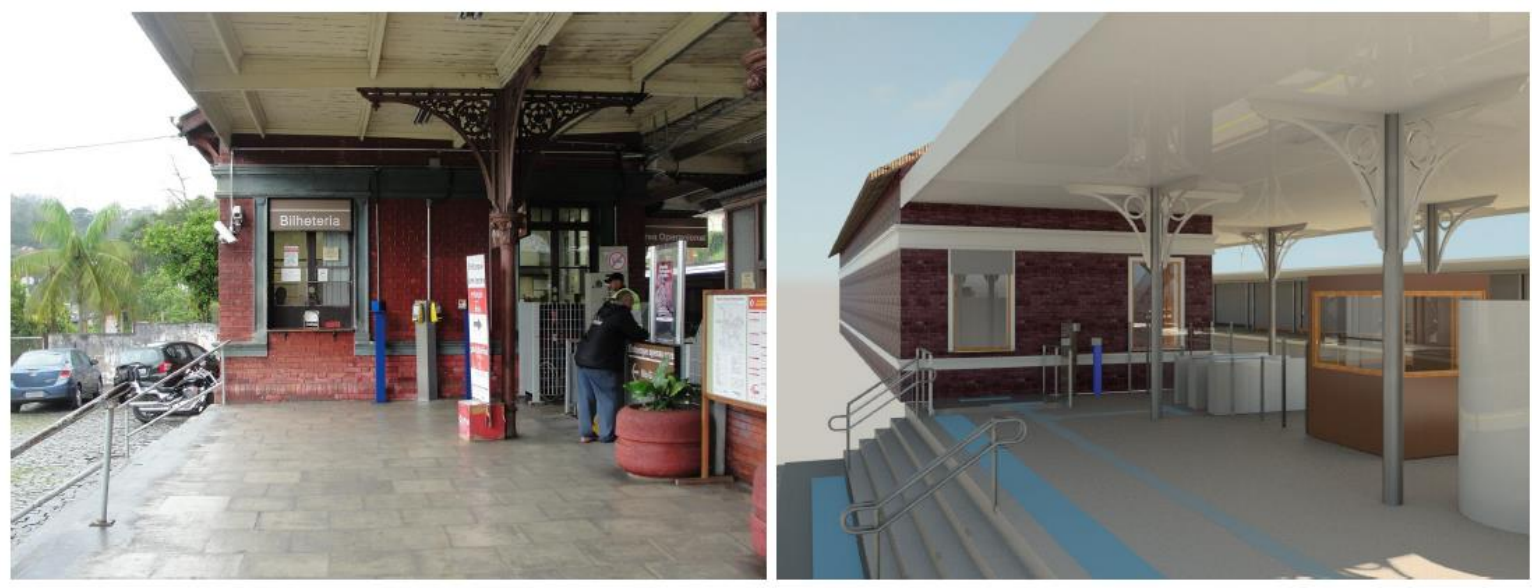

Fonte: Cavalcanti (2018)

Posteriormente, foi utilizado o modelo também para a extração de quantitativos, empregando, nessa atividade, o Revit e o Dynamo. Os profissionais contam que desenvolveram um fluxo e definiram códigos para os elementos, pensando na melhor extração da planilha de quantitativos, para garantirem a assertividade e a qualidade da informação. Para isso, a consultoria criou as rotinas no Dynamo, tendo em vista o pouco conhecimento na ferramenta adquirida pelos colaboradores da Empresa 2, conforme relata a arquiteta. Após a modelagem existente, projetaram a fase de demolição e, em seguida, a fase de reforma, conforme pode ser verificado na Figura 33 a seguir. A profissional conta que devido aos atrasos desse projeto, eles não tiveram tempo de verificarem a qualidade da extração de quantitativos. 
Figura 33 - Fases de modelagem

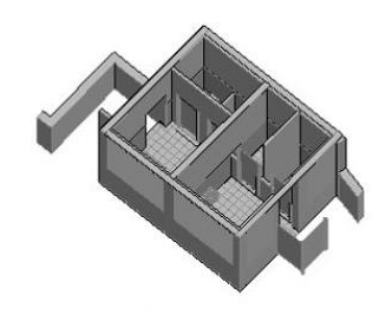

(1) SANITARIOS - FASE EXISTENTE

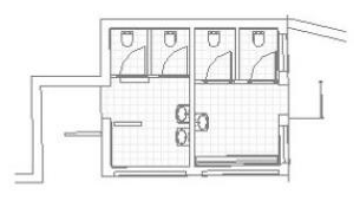

(4) SANITARIOS - FASE EXISTENTE

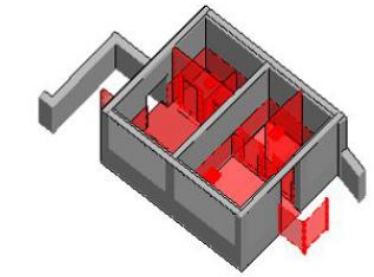

(2) SANITARIOS - FASE DEMOLICCÄO

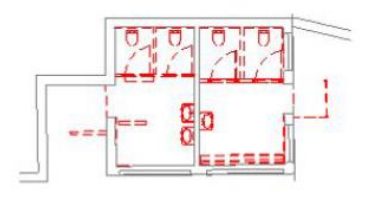

(5) SANITARIOS - FASE DEMOLIÇĀO

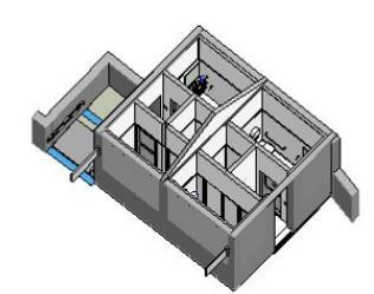

(3) SANITARIOS - FASE NOVA CONSTRUCQÄO

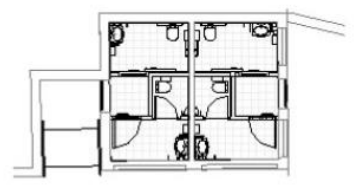

(6) SANITARIOS - FASE NOVA CONSTRUÇĀO

Fonte: Cavalcanti (2018)

Os colaboradores contam que após a primeira experiência, eles tiveram uma série de lições aprendidas, como o envolvimento prévio das equipes de manutenção e obras no projeto, a impossibilidade dos profissionais se dividirem entre as suas atividades diárias e o desenvolvimento de um projeto em BIM, a necessidade de uma coordenação para o projeto em BIM, dentre outras questões. Além disso, os profissionais comentam que a falta de definição de papeis e responsabilidades foi um dos fatores que levou à falta de motivação de alguns profissionais. O que se esperava deles não havia sido definido claramente ou não possuía muita conexão com as atividades das quais eles realizavam nas suas áreas no dia a dia.

Portanto, ao iniciar o segundo projeto-piloto definiram que um dos arquitetos ficaria responsável pela coordenação desse, além do desenvolvimento de reuniões de aprovação com as áreas de obras, operação e manutenção durante o desenvolvimento do projeto e a verificação das incompatibilidades entre os modelos. Ademais, haveria um tempo prévio ao início do projeto para a atualização das adequações que deveriam ser feitas, para o planejamento do cronograma, levantamentos in loco sobre as instalações e as reuniões de definição prévia com toda a equipe de modelagem. Para essa segunda experiência, alguns projetistas foram substituídos para darem oportunidade a outros colaboradores da empresa aprenderem na prática sobre o desenvolvimento de projetos em BIM. 
Figura 34 - Situação anterior x modelo - Plataforma
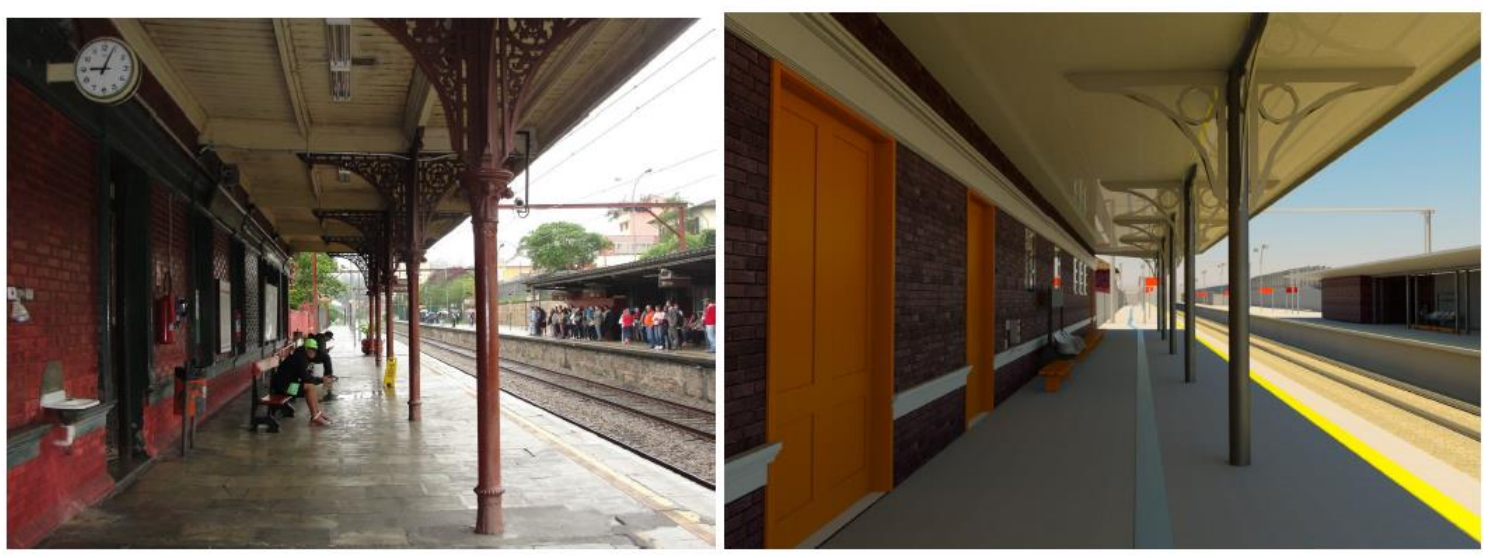

Fonte: Cavalcanti (2018)

A arquiteta conta que essas lições aprendidas tiveram muito impacto no desenvolvimento do segundo projeto-piloto, havendo a diminuição do retrabalho e melhoria na comunicação com o envolvimento das equipes e obras, operação e manutenção previamente no projeto; diminuição do tempo de projeto em comparação com o primeiro, com os integrantes da equipe focados nele, exclusivamente; melhora na fluxo de desenvolvimento do projeto, a partir da colaboração entre a equipe; definição clara de papeis e responsabilidades, o que motivou os profissionais do projeto BIM.

Outros benefícios identificados pelos colaboradores foram a comunicação simplificada por estarem em um mesmo ambiente e compartilharem os comentários nos projetos pelo software BIM 360 Team, o ganho no tempo com a modelagem simultânea a partir do modelo federado em Revit, a detecção de interferências facilitada pelo software Navisworks poupando tempo e evitando que elas passassem despercebidas, interação com todas as equipes envolvidas que serão impactadas posteriormente com o projeto, o que não ocorre em projetos normais, maior precisão nos levantamentos de quantitativos, melhoria na qualidade dos projetos, aumento da confiabilidade no projeto final, aperfeiçoamento da visualização e entendimento do modelo pela alta hierarquia.

Apesar de todos esses benefícios, os funcionários desta organização que foram entrevistados contam que ainda não conseguiram alcançar os objetivos de diminuição de prazo na elaboração do projeto, portanto, não foi possível comprovar o aumento da produtividade. A arquiteta evidencia que a resistência à mudança 
também é algo ainda presente na empresa sobre esse tema, visto que nem todos os colaboradores selecionados para as experiências tiveram interesse e, por esse motivo, foram substituídos, posteriormente, no projeto por outros profissionais.

Para estimular os colaboradores, o gerente conta que após o primeiro projeto realizaram a divulgação dos resultados, evidenciando os benefícios e as conclusões. Essa estratégia gerou soluções positivas na opinião dos profissionais, pois houve a valorização do projeto de implantação do BIM nas experiências posteriores. Outro resultado foi a criação de um departamento focado na implantação e na administração do Processo BIM na empresa, para garantir a qualidade desse processo e dos seus resultados, o Departamento de Consistência e Inovação de Projetos (DPPG), sendo uma iniciativa da Diretoria da Empresa 2 para institucionalizar a adoção do BIM nela. A partir disso, foi criado um fluxo para o processo de projeto BIM quando houver a contratação de novos projetos para manter a padronização deles dentro da Empresa 2, também atualizam periodicamente o BIM Mandate, fazendo a gestão das licenças dos softwares, bem como a compra dos equipamentos necessários.

O novo fluxo de trabalho definido pela Empresa 2 então consiste na criação de um BIM Execution Plan apresentado pela projetista ao início do contrato, seguido pelos levantamentos mínimos para o início do projeto e a aprovação das etapas pela equipe interna da empresa. A arquiteta comenta que definiram também no Mandate quais são as disciplinas que deverão ser modeladas prioritariamente e que a compatibilização do modelo deveria ser feita constantemente. A empresa substituiu as entregas por tipos de projeto funcional, básico e executivo, por níveis de detalhamento do modelo e definiu reuniões de aprovação interna em cada uma das etapas para evitar o retrabalho. Foi apresentado o Quadro 2, na qual a arquiteta analisa as mudanças na Empresa 2 entre os projetos convencionais e os projetos BIM. 
Quadro 2 - Comparação do processo de projeto convencionalmente utilizado na Empresa 2 com o processo de projeto BIM

\begin{tabular}{|c|c|}
\hline Processo convencional & Processo projetos estudo de caso \\
\hline 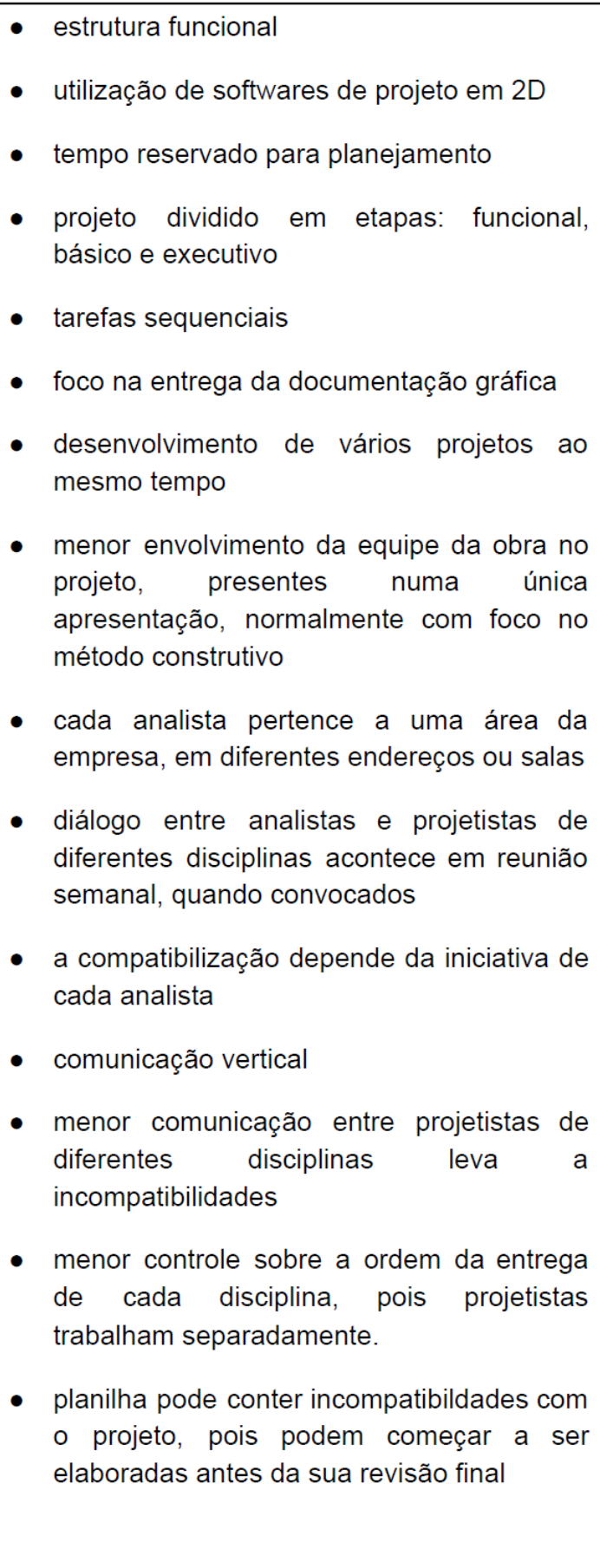 & 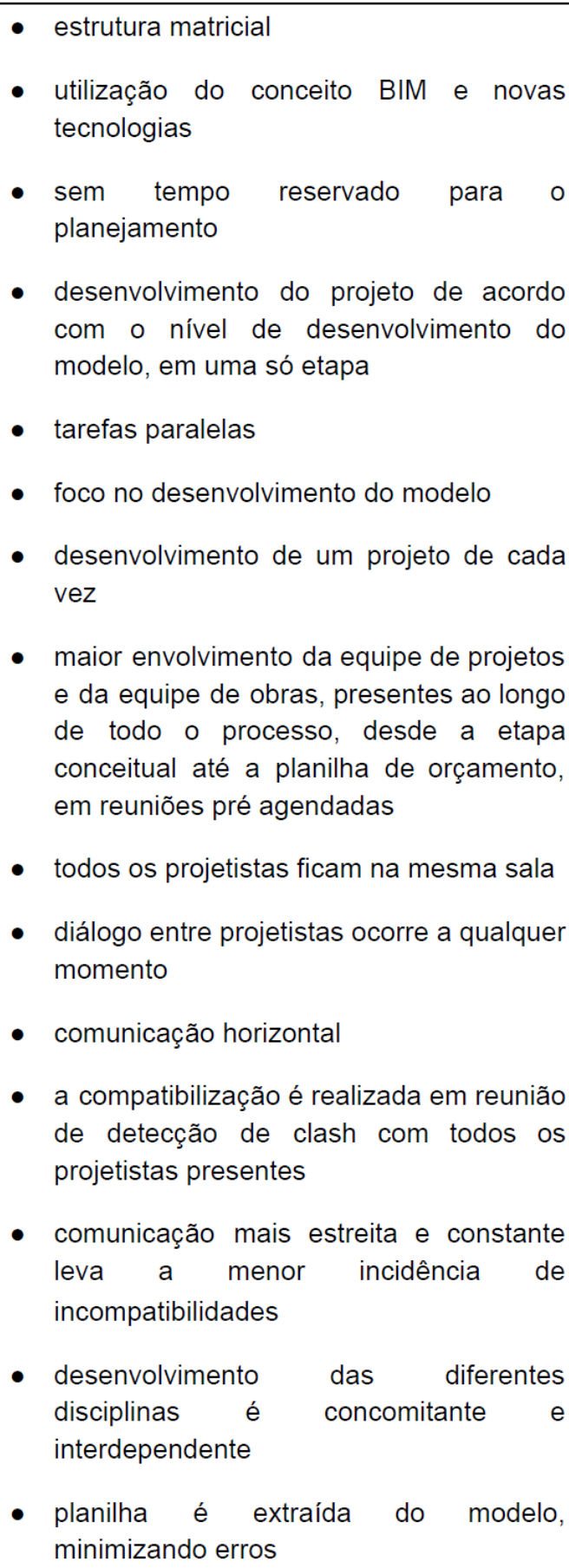 \\
\hline
\end{tabular}

Fonte: Cavalcanti (2018) 
Após os dois projetos-pilotos, concluiu-se com a construção da Sala BIM, que estava sendo montada com softwares, rede e hardwares específicos dentro da Empresa 2. Foram realizados, então, mais três projetos da mesma natureza, que seguiram o mesmo fluxo da segunda experiência com o levantamento com o laser scanning, verificação in loco dos sistemas e todo o resto do fluxo, aproveitando para retroalimentar os próximos com lições aprendidas do anterior.

Os profissionais contam que os cinco projetos BIM desenvolvidos pela Empresa 2 viraram licitações de obras com prazo estipulado de seis meses, sendo solicitado que após a realização da reforma, a contratada entregasse o modelo BIM atualizado com o as built para entregarem para as áreas de operação e manutenção. Eles contam que esse foi um dos itens para o pagamento de uma das etapas da licitação, porém, no início acreditavam que não seria entregue pelas empresas, porque normalmente se trata de empreiteiras muito pequenas e que não possuem o conhecimento para desenvolverem o as built.

Por esse motivo, quando incluíram essa solicitação na licitação, não indicaram a sua obrigatoriedade, mas foi um dos itens para o faturamento de uma parcela do contrato. Apesar disso, como uma tentativa de contribuir para o conhecimento das empresas contratadas, a Empresa 2 fez uma parceria com o SENAI, para que eles auxiliassem as contratadas com essa etapa do serviço, dando cursos e suportes para o desenvolvimento e entrega do modelo as built. Caso as empresas não entregassem o as built, a Empresa 2 não desenvolveria um fluxo para eles modelarem internamente.

Os profissionais contam que os as built dos dois primeiros projetos-pilotos não foram entregues, porém dos outros dois seguintes foram entregues pela empresa contratada. A ideia inicial era de que esses modelos fossem sendo atualizados, conforme as obras fossem acontecendo, porém, eles acabaram sendo desenvolvidos da maneira convencional apenas após a obra. Esses modelos das intervenções concluídas têm o objetivo de serem repassadas para as equipes de operação e manutenção para servirem de base de informação para usos futuros, porque o BIM ainda não chegou nessas áreas da Empresa 2. O atual responsável da área conta que o BIM está sendo implantado na organização de maneira gradual. Ele já foi implementado na área de projetos e agora está sendo realizado na área de obras, a princípio com o as built e, posteriormente, com o acompanhamento 4D, para depois chegar nas áreas de operação e manutenção. Os colaboradores que 
participaram desta pesquisa relatam, também, que a extração de quantitativos dos modelos evoluiu muito entre o primeiro e o último projeto. A quinta obra apresentou uma acurácia elevada quanto às quantidades previstas.

O Departamento de Consistência e Inovação de Projetos era composto em 2018 por seis colaboradores, sendo o chefe de departamentos, um administrador, um arquiteto e três engenheiros. Eles atuam na consistência dos modelos e das planilhas de extração de quantitativos desenvolvidas, na revisão da biblioteca BIM da organização e na revisão do Mandate. Foi iniciado em 2018 um processo de integração da biblioteca BIM com os bancos de dados públicos para a precificação, exigência para empresas estatais, como o SINAPI, a Caixa, o Sicro ou o DNIT para obras de infraestrutura, com o objetivo de extrair os quantitativos rapidamente para licitar as obras.

Em 2019, o departamento ficou responsável por todas as inovações tecnológicas da empresa, não apenas o BIM, mas os projetos em BIM continuarão sendo acompanhados e gerenciados por essa área. Os profissionais da equipe indicam que, a princípio, os novos projetos de adequação serão todos contratados por empresas terceiras, devido ao escopo, nível de urgência e disponibilidade de equipe interna. A Sala BIM será utilizada para realizar esse acompanhamento dos projetos, análise e validação dos modelos entregues. A Empresa 2 possui a diretriz da diretoria de não contratar projetos que não sejam em BIM, exceto alguns específicos, como, por exemplo, os de infraestrutura linear. Porém, os próximos projetos de adequação de acessibilidade das estações não serão entregues em BIM, porque as licitações são antigas, sendo de 3 ou 4 anos atrás, em que não foi solicitada essa entrega.

Os profissionais contam que para os próximos projetos em BIM, eles amadureceram a forma de contratação, entendendo melhor o que deve ser solicitado, as suas especificações, como e quanto devem pagar. Ainda não houve a contratação plena de projetos em BIM, tendo em vista as licitações vigentes e a quantidade de projetos que a Empresa 2 está contratando, mas o caderno BIM que estão desenvolvendo prevê o fluxo do trabalho no 3D para a melhoria da visualização e o entendimento do projeto, no 4D para otimizar o planejamento das obras e no 5D para melhorar a consistência das planilhas de quantitativos para compra, sendo esses os objetivos que a empresa busca. Em relação ao investimento para a implantação do BIM nas organizações, os colaboradores 
entendem que se está dividido em $20 \%$ e $30 \%$ a relação software e hardware e os outros $50 \%$ para investimento em pessoas, capacitação e treinamentos. A Sala BIM criada na Empresa 2 é utilizada para treinamentos em geral na empresa, sejam de ferramentas BIM ou não, para revisarem os projetos BIM quando chegam da contratada e para a criação e a atualização dos elementos da biblioteca BIM da organização, porém em alguns momentos essa sala fica ociosa. Apesar de toda essa preparação para receber e desenvolver os projetos em BIM, o profissional acredita que eles nunca terão uma mudança completa de todos os projetos para o BIM e sempre terão o CAD para realizarem projetos e atividades ainda no $2 \mathrm{D}$.

\subsection{EMPRESA 3}

A Empresa entrevistada se trata de uma construtora multinacional com mais de 75 anos de atuação no mercado de infraestrutura e mais de 50 mil funcionários. Atua em 8 países, realizando grandes obras de sistemas de transportes, construções industriais, de energia, saneamento, mineração, óleo e gás, dentre outras áreas. O estudo de caso nessa organização foi desenvolvido a partir de entrevistas com o Gerente da área de Construção Virtual responsável por implantar o BIM na companhia e uma das analistas que atua diretamente com os projetos.

Os profissionais entrevistados contam que a adoção do BIM nessa empresa foi contemplada em 2011 por um diretor da organização, na época. Esse profissional era visto como um visionário na organização e possuía a percepção da necessidade por inovação que o setor da construção civil possui e, portanto, buscava entender e trazer para a companhia as melhores soluções que pudessem melhorar o desempenho e a qualidade do produto final da empresa. Na época, o gerente conta que essa decisão foi também uma decisão estratégica, visto que a construtora tem o objetivo de ser vista nacionalmente no mercado como pioneira em inovações e sempre utilizou nos seus processos ferramentas de primeira linha.

Nesse período, o profissional entrevistado conta que a empresa possuía uma área chamada Engenharia Virtual, com uma equipe técnica de implantação de novas tecnologias composta por sete profissionais, que atuava como prestadora de serviços para as áreas de engenharia, projetos e obras, quando essas solicitavam estudos para o desenvolvimento dos seus trabalhos. Para a adoção do BIM na empresa, o diretor optou então pela contratação de um profissional do mercado que 
já atuasse com o método BIM e que foi nomeado então gerente dessa área técnica de implantação de novas tecnologias, conforme conta a profissional. Nesse momento novas ferramentas e expertises foram incorporadas à organização, inclusive a utilização de ferramentas de modelagem 3D da Autodesk, como o AutoCAD Civil 3D e o Revit, visto que o profissional contratado possuía experiência em ferramentas da Autodesk. Foi relatado também que, apesar desse esforço, o objetivo e a estruturação da área não tinham como foco a implementação do processo BIM na empresa e possuía uma série de outras frentes de atuação, visando as diversas tecnologias e inovações do mercado.

Por esse motivo, os profissionais entrevistados contam que a implantação do BIM durante o período de 2011 e 2014 contemplou apenas a utilização dos softwares de modelagem 3D para o desenvolvimento de propostas comerciais e os estudos de canteiro. Durante essa fase os profissionais da área de Engenharia Virtual relatam que passaram a adquirir maior conhecimento nas ferramentas do mercado pelos treinamentos e especializações contratados e, posteriormente, realizaram treinamentos internos para as áreas corporativas e de obras com o objetivo de ensinar os profissionais dessas áreas a utilizarem ferramentas mais avançadas, como o AutoCAD Civil 3D e o Infraworks.

A empresa desenvolveu também diversos webcasts na intranet da empresa, apresentando o BIM e dando treinamentos superficiais sobre algumas ferramentas, com o objetivo de mostrar as inovações do mercado e despertar o interesse dos colaboradores. A profissional indica que a área de engenharia virtual foi muito útil para a empresa, pois trouxe um know-how muito grande das novas ferramentas do mercado para os profissionais internos que ainda não possuíam o conhecimento.

Relatou-se que, em paralelo, nessa época foram construídas refinarias e, por demanda do contratante, foi exigido o planejamento 4D dessas obras. Foi utilizada a ferramenta Synchro para realizar esse planejamento e houve a necessidade da contratação de um profissional experiente do mercado para esse trabalho específico, visto que os profissionais da área não possuíam conhecimento sobre o 4D, porque os treinamentos recebidos pela equipe contemplavam apenas o 3D. Apesar do 4D e do BIM não terem sido o foco da área de Engenharia Virtual naquela época, os profissionais da área tiveram a oportunidade de adquirirem esse knowhow devido às obras contratadas nesse período. Além disso, essas aplicações de BIM em infraestrutura (óleo e gás) foram reconhecidas nacionalmente. Na opinião 
dos profissionais entrevistados isso se concretizou também porque no Brasil ainda não existem grandes utilizações do BIM em infraestrutura.

Em 2013, foram criados internamente na empresa projetos de inovação disruptiva, motivados pela obra de uma usina hidrelétrica que estavam finalizando a sua construção e que já havia se estendido por quase 10 anos. Nesse período, a empresa passou por uma série de dificuldades na obra devido à precariedade dos projetos em 2D, como desperdício de concreto, perda do prazo contratual, dificuldade na comunicação entre os envolvidos e falta de planejamento, conforme relata a profissional.

Para o desenvolvimento desse projeto de inovação estratégica a empresa focou nos problemas que tinham com o concreto nas obras e procuravam maneiras de diminuírem o desperdício. Para isso desenvolveram estudos, pesquisas internacionais, análises de mercado, estudos acadêmicos, fórum com fornecedores, dentre outras iniciativas que os profissionais relataram. Dentre toda essa pesquisa exploratória para encontrar uma solução para o problema do desperdício de concreto, o gerente da área entende que o BIM surgiu como a mais promissora em relação aos resultados, com a possibilidade não só de ajudar com o desperdício do concreto nas obras, mas também com uma série de outras questões e dificuldades que a empresa tinha com obras de grande porte.

Após essa conclusão da pesquisa, nos últimos anos da obra da hidrelétrica contam que ainda foi possível aplicar algumas das descobertas, como a modelagem 3D, o planejamento 4D, o uso de tecnologias para levantamento do terreno, o laser scanning para o controle de estoques, levantamentos, dentre outros pioneirismos nas obras da empresa, pois foram as primeiras aplicações dessas inovações. Nesse caso, foi o primeiro trabalho com o modelo BIM na empresa e causou um grande impacto, porque, na opinião dos profissionais entrevistados, o uso do 2D dificulta muito a visualização da necessidade de melhorias no projeto, o que é extremamente facilitado com a modelagem 3D da obra, devido à melhor visualização e à conversa mais clara com o cliente, por intermédio do modelo.

A engenheira conta que o ciclo de inovação tecnológica realizado gerou um grande mapa de oportunidades e uma delas foi utilizar o BIM em todas as obras, o que foi fortemente fomentado devido à necessidade de melhorar os resultados da empresa nas obras em concreto. Essa necessidade se estendeu a tudo relacionado ao concreto e não apenas ao material em si, como também à armação, ao 
lançamento, às formas, ao tratamento do concreto, dentre outras questões, pois o concreto sempre foi o principal material nas obras de infraestrutura da empresa.

Os profissionais relatam que em 2014, com a chegada de um novo profissional experiente do mercado para gerenciar a área, ela tomou um rumo diferente e começou a se estruturar melhor e nesse momento recebeu o nome de área de Construção Virtual. A partir disso, o objetivo dessa área foi o de deixar de ser um departamento de apoio às obras e começar a levar as tecnologias e as novas metodologias para a obra, ou seja, foi um esforço para transformar o BIM em um processo empresarial, em uma nova maneira da empresa trabalhar, fomentada pela alta hierarquia, conforme conta o profissional. O Projeto de Inovação estratégica deu início à adoção do BIM nas obras e começou com a contratação de uma consultoria de implantação do BIM, que a princípio realizou treinamentos para a equipe dessa área e, posteriormente, auxiliou na escolha do Projeto-Piloto, conforme se pode observar na Figura 35.

Figura 35 - Timeline de implantação do BIM na Empresa 3

\section{TIMELINE EMPRESA 3}

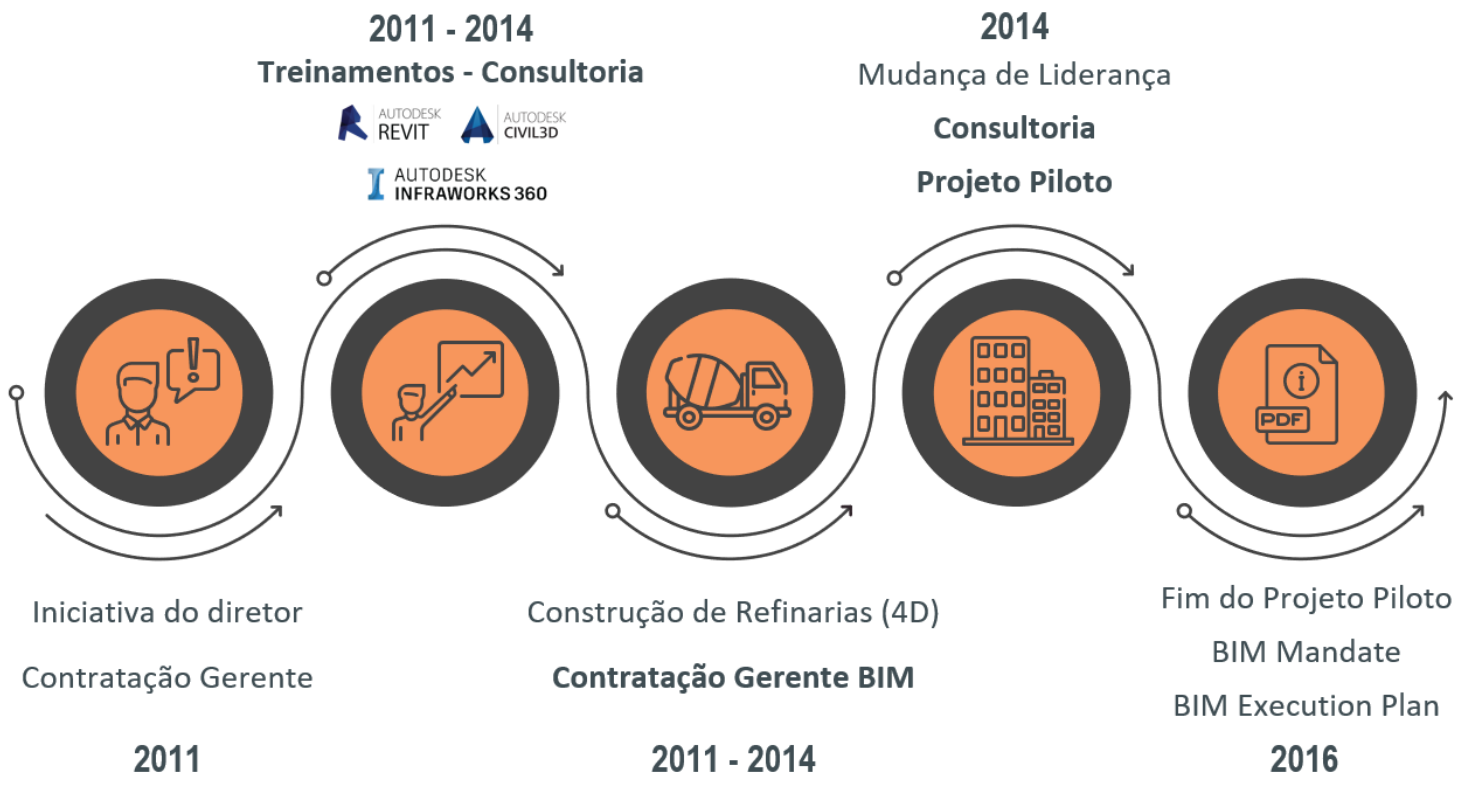

Fonte: A autora (2019) 
O profissional conta que em conjunto com a consultoria definiram a obra que seria o Projeto-piloto da implantação do BIM. Foi escolhida a construção de duas linhas de metrô com aproximadamente 15 estações e todo o sistema metroviário no nordeste do país. Ele analisa que foi outro imenso desafio para a empresa, pois a proposta foi de construir todo o sistema metroviário e estações em um período de quatro anos. Naquele momento já havia uma primeira fase iniciada pela prefeitura que não havia sido inaugurada. No período de 10 anos foram construídas apenas três estações. O contrato dessa construção foi uma (Parceria Público-Privada) e a Empresa 3 foi a líder do consórcio.

O gerente da área conta que quando a empresa decidiu que essa construção seria o seu piloto para a implantação do BIM na organização, levaram ao consórcio essa proposta de utilizar as ferramentas BIM, já que era uma grande oportunidade, tendo em vista a proporção da obra e a capacidade de retorno da utilização do BIM em empreendimentos de grande porte. Junto com a proposta, contam que levaram também todo o estudo de inovação que foi feito previamente para embasar sua proposta em utilizar esse método.

A partir disso, o consórcio, a obra e o contratante decidiram adotar o processo BIM nessa obra. Os profissionais contam que quando iniciaram o projeto executivo da linha 1 já estava pronto em 2D, pois ele fazia parte do escopo da primeira fase que ficou em execução por 10 anos. Então, para conseguir desenvolver essa obra, a empresa contratou a Consultoria BIM para dois trabalhos específicos: o primeiro era o de modelar todos os projetos das estações que estavam em 2D em LOD suficiente para realizar a compatibilização de projetos e o planejamento 4D, porém houve uma certa dificuldade, visto que nem todos os projetos eram executivos, uma vez que possuíam muitos projetos básicos e alguns ainda eram conceituais. $O$ segundo escopo era o de estruturar o processo BIM dentro da obra, realizar todo o plano de execução BIM para aquela construção específica, para esse trabalho a consultoria designou uma das suas consultoras mais experientes em BIM para ficar em tempo integral, acompanhando a obra junto com o atual gerente da área de Construção Virtual da Empresa 3.

Em 2014, a profissional conta que foi feita a modelagem dos projetos de estrutura, arquitetura, sistema de drenagem e instalações subterrâneas das estações e o complexo de manutenção, que seria uma parte crucial da obra e teria um prazo muito curto de execução. Os profissionais enfatizam que esse esforço 
inicial de modelagem foi feito porque todos os projetos estavam em 2D e havia a necessidade da compatibilização dos mesmos e utilização para outros fins, como planejamento, cronograma, extração de quantitativos, dentre outros aspectos. Em paralelo, surgiu um número imenso de projetos em 2D sendo revisados, porque como eles haviam sido desenvolvidos para a construção da fase 1 da obra que começou em 2005, estavam desatualizados em relação às soluções construtivas e poderiam gerar prejuízos, na opinião do gerente. Por esse motivo, o responsável pela área relata que na época as empresas projetistas contratadas para atualizarem os projetos 2D não trabalhavam com BIM e, portanto, todas essas novas revisões de projetos em 2D tiveram que ser remodeladas nos moldes que já haviam sido desenvolvidos pela consultoria, conforme se pode verificar na Figura 36. Devido ao grande número de revisões, a construtora e a consultora precisaram criar um processo para identificarem as últimas versões dos projetos que estavam sendo revisados e solicitarem a atualização do modelo.

Figura 36 - Fluxo de Modelagem

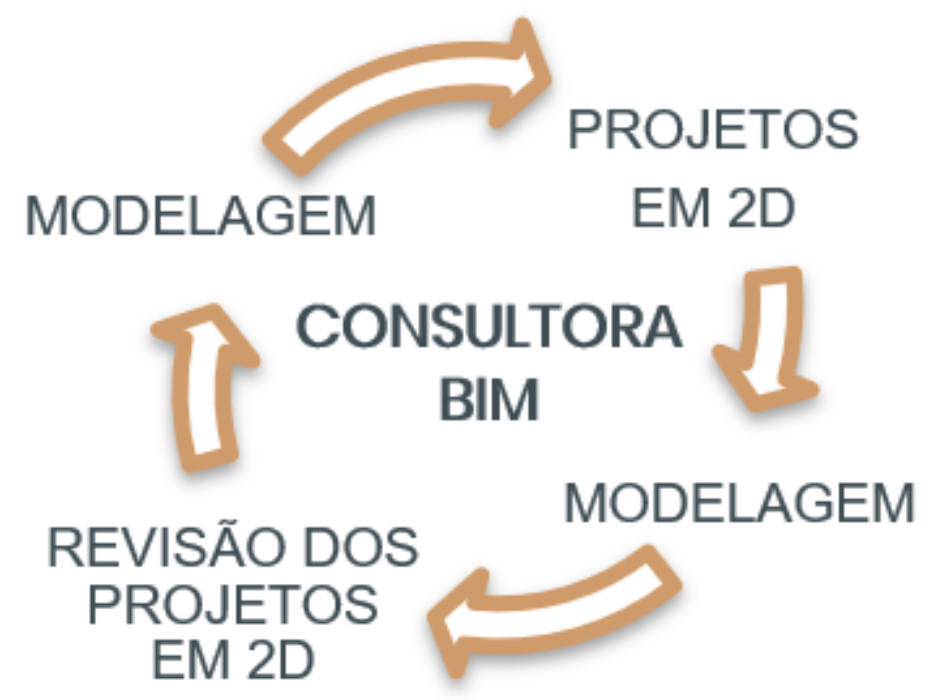

Fonte: A autora (2019)

O modelo BIM da obra foi utilizado basicamente para dois objetivos distintos: o primeiro era o de compatibilizar os projetos, porque o projeto executivo basicamente estava sendo desenvolvido em paralelo com a obra e o segundo foi o de utilizá-lo para realizar o planejamento $4 \mathrm{D}$, conforme conta a engenheira. $\mathrm{O}$ uso do BIM para o planejamento da obra foi escolhido pela empresa, tendo em vista os grandes benefícios que ele traz para o desenvolvimento da construção e para uma 
participação mais ativa e compreensão do cliente, como relata o gerente. Visando o desenvolvimento do 4D, a empresa entendeu que aquele momento seria ideal para treinar a equipe da obra para realizar o planejamento 4D, então contratou um profissional experiente do mercado com esse objetivo.

Os profissionais contam que apesar dos esforços que fizeram e da oportunidade evidente em treinar os profissionais da obra responsáveis pelo planejamento para utilizarem a ferramenta Synchro, isso não foi possível. $\mathrm{Na}$ opinião do gerente, essa dificuldade ocorreu devido à mentalidade dos profissionais e à grande recusa deles, que alegavam estar focados em pensar no dia a dia da obra e que não tinham tempo para aprenderem uma nova ferramenta, mesmo que fosse para melhorar o planejamento da obra. Em 2014, então, o processo de modelagem 3D foi estruturado na construção e foi implantado o planejamento 4D com o acompanhamento e a atualização semanal.

Assim, contam que os engenheiros da obra continuaram fazendo o seu planejamento na ferramenta Primavera, enquanto a profissional contratada compatibilizava o modelo 3D com o planejamento do software Primavera para gerar o 4D, conforme se pode verificar na Figura 37. O modelo 4D era então apresentado em reuniões periódicas para os engenheiros da obra, para que eles refinassem os seus cronogramas e definissem metas semanais. O profissional entrevistado relata que esse modelo 4D ajudou muito no planejamento da obra, possibilitando aos engenheiros levar essas metas semanais a campo, junto com o modelo 3D para discutir com os encarregados diretamente no campo, o que trouxe uma facilidade muito grande em termos de gestão da obra e comunicação. 
Figura 37 - Esquema para desenvolver o Modelo 4D

\section{Modelo 3D \\ Planejamento Primavera}

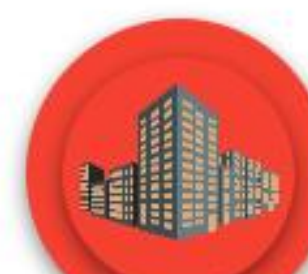

Modelo 4D

Fonte: A autora (2019)

Como esse era o projeto-piloto da empresa, o profissional entrevistado comenta que mensalmente eles reportavam a evolução da obra para todos os envolvidos no projeto, tanto da alta hierarquia da Empresa 3, quanto do consórcio. Não foi possível realizar a extração de quantitativos do modelo devido à grande quantidade de revisões nele por causa das revisões dos projetos em 2D em paralelo, o que fez com que o modelo tivesse baixa confiabilidade, conforme explica a engenheira. Além disso, comentou-se que um modelo para a extração de quantitativos precisava ser muito detalhado, porém que não possuíam tempo para desenvolvê-lo dessa maneira. Devido a essas questões, não foi possível extrair as quantidades do modelo.

$O$ atual gerente da área de Construção virtual conta que ficou em tempo integral na obra durante 2014, mas em 2015, após estruturar o processo BIM dentro da obra, ele voltou para São Paulo devido às outras necessidades que a área possuía. Apesar do processo BIM estar estruturado e funcionando, em 2016 houve uma mudança na gestão da obra, na qual o projeto-piloto estava em andamento e o novo gestor decidiu por não utilizar mais o processo BIM nos anos seguintes. Isso fez com que não conseguissem analisar por completo os resultados que o BIM trouxe para a construção, o que conclui o profissional. Apesar da grande complexidade da obra com 15 estações e toda a infraestrutura metroviária, foi possível concluí-la praticamente dentro do prazo de quatro anos estipulado 
inicialmente, porém os profissionais não conseguiram aferir se parte do cumprimento desse prazo se deu devido à utilização do processo BIM na organização. Essa obra na Bahia foi finalizada, porém durante os anos de 2016, 2017 e 2018 não utilizou o BIM em decorrência da troca de liderança, conforme timeline da Figura 38.

Figura 38 - Timeline da implantação do BIM na obra piloto

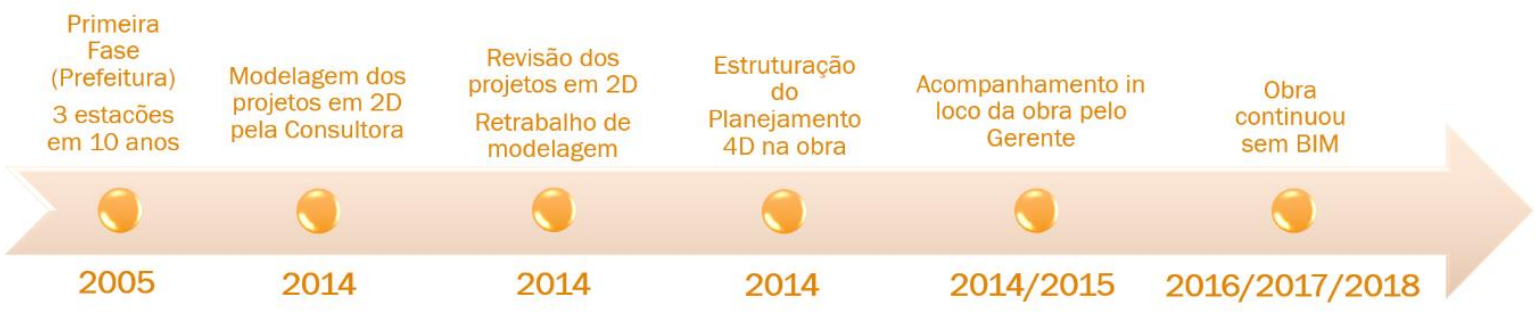

Fonte: A autora (2018)

Após toda a experiência do projeto-piloto, uma das profissionais entrevistadas relata que com 0 3D foi possível identificar dificuldades de construtibilidade e incompatibilidades na obra, o que foi muito importante para antecipar problemas, diminuir retrabalhos e minimizar o tempo. Além disso, apontou-se, também, que ficou claro que a decisão de realizar o desenvolvimento da modelagem ao mesmo tempo em que a obra acontecia não valeu a pena, porque dessa maneira os benefícios e os recursos do BIM foram minimamente aproveitados e os colaboradores não conseguiram ter a visão do ganho que o BIM trouxe para o negócio. Apesar disso, ela indica que a utilização do BIM para o planejamento foi uma experiência muito boa para eles, ajudando a obra (Figura 39, 40, 41) enquanto estava sendo aplicado, principalmente, no acompanhamento da produção, compatibilizações de projetos e nas reuniões semanais. Além dessa experiência do projeto-piloto, os profissionais relatam outras experiências posteriores menores, como a aplicação do BIM em propostas de novos projetos que trouxeram bons resultados, como na etapa de orçamento da proposta, que é realizado a partir do planejamento 4D que a Empresa 3 já consegue fazer durante o desenvolvimento do modelo da proposta, o que faz com que eles passem para o cliente final um custo muito mais assertivo e justo. 
Figura 39 - Obra piloto da Empresa 3 concluída

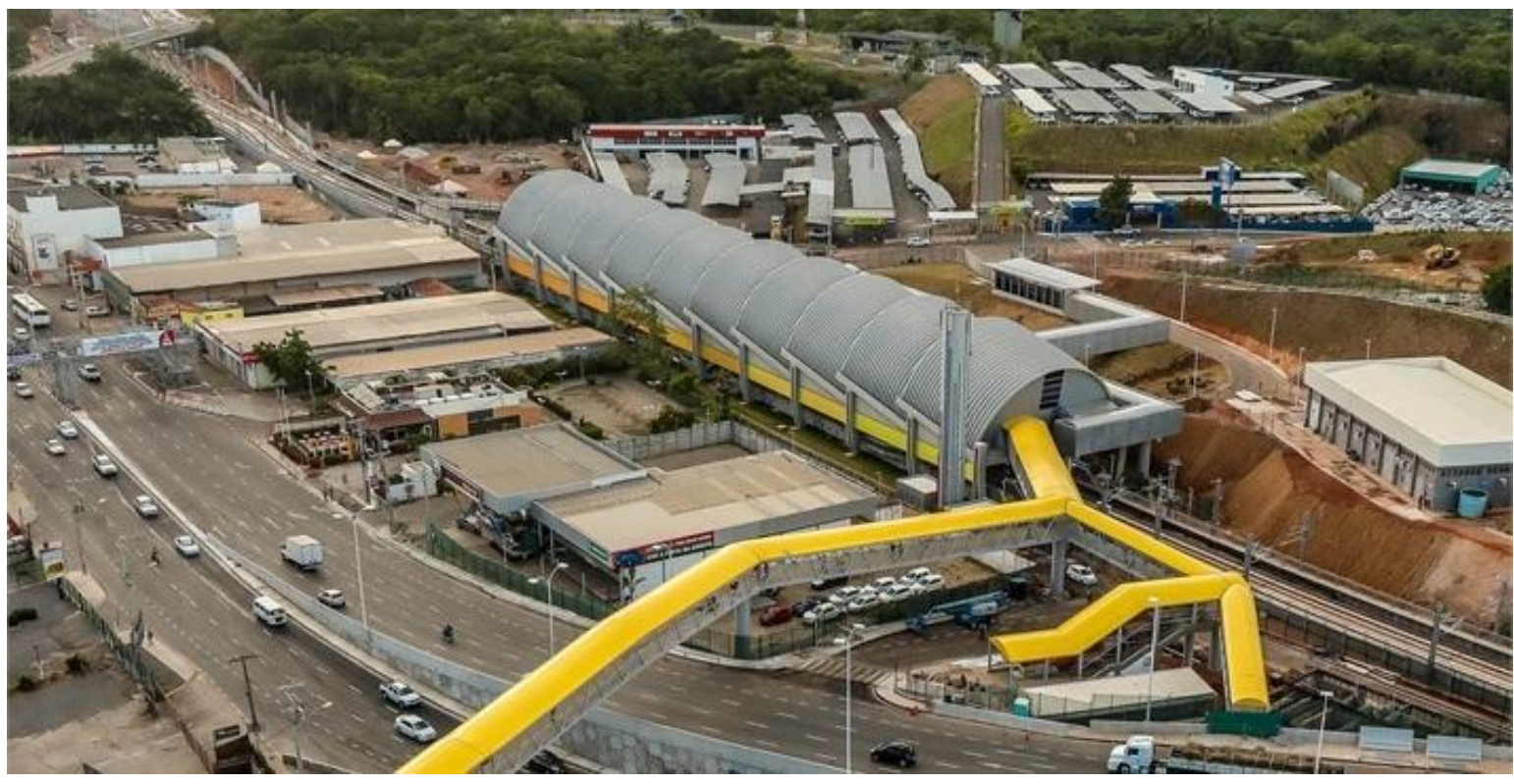

Fonte: Mapa Metro (2018)

Figura 40 - Obra piloto da Empresa 3 concluída

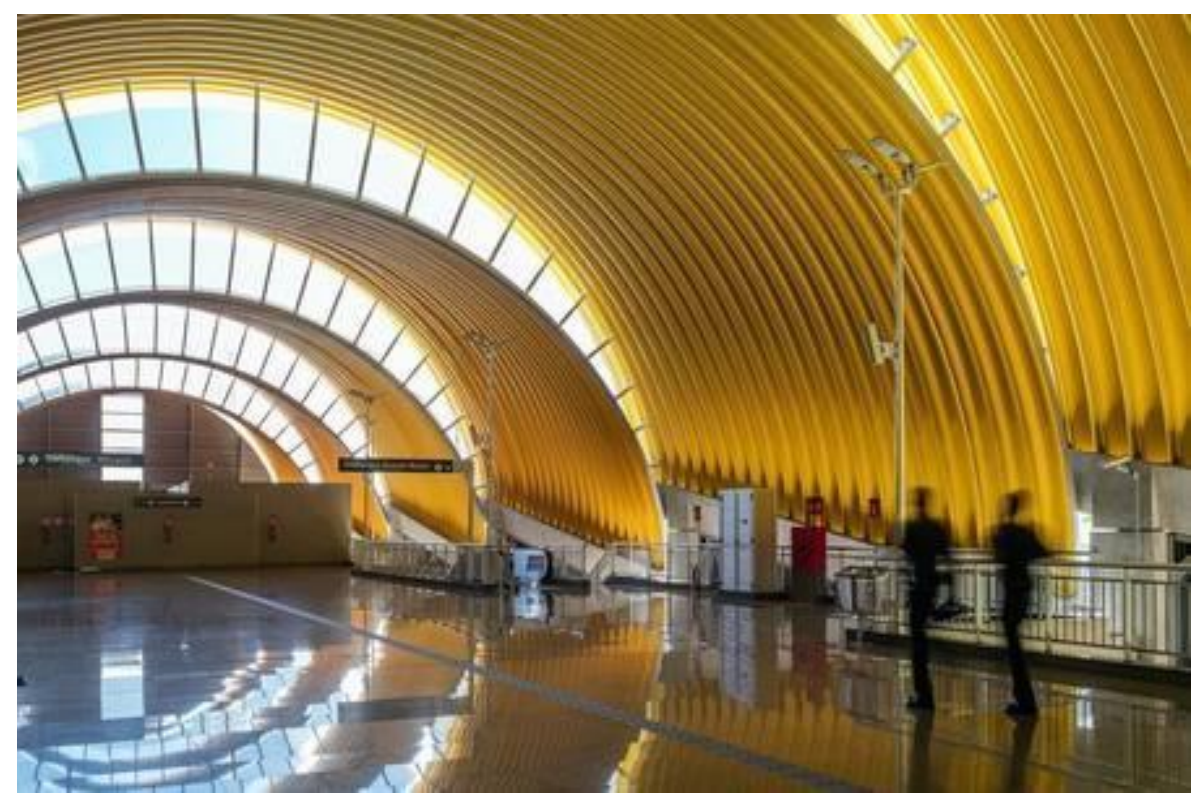

Fonte: Mapa Metro (2018) 
Figura 41 - Obra piloto da Empresa 3 concluída

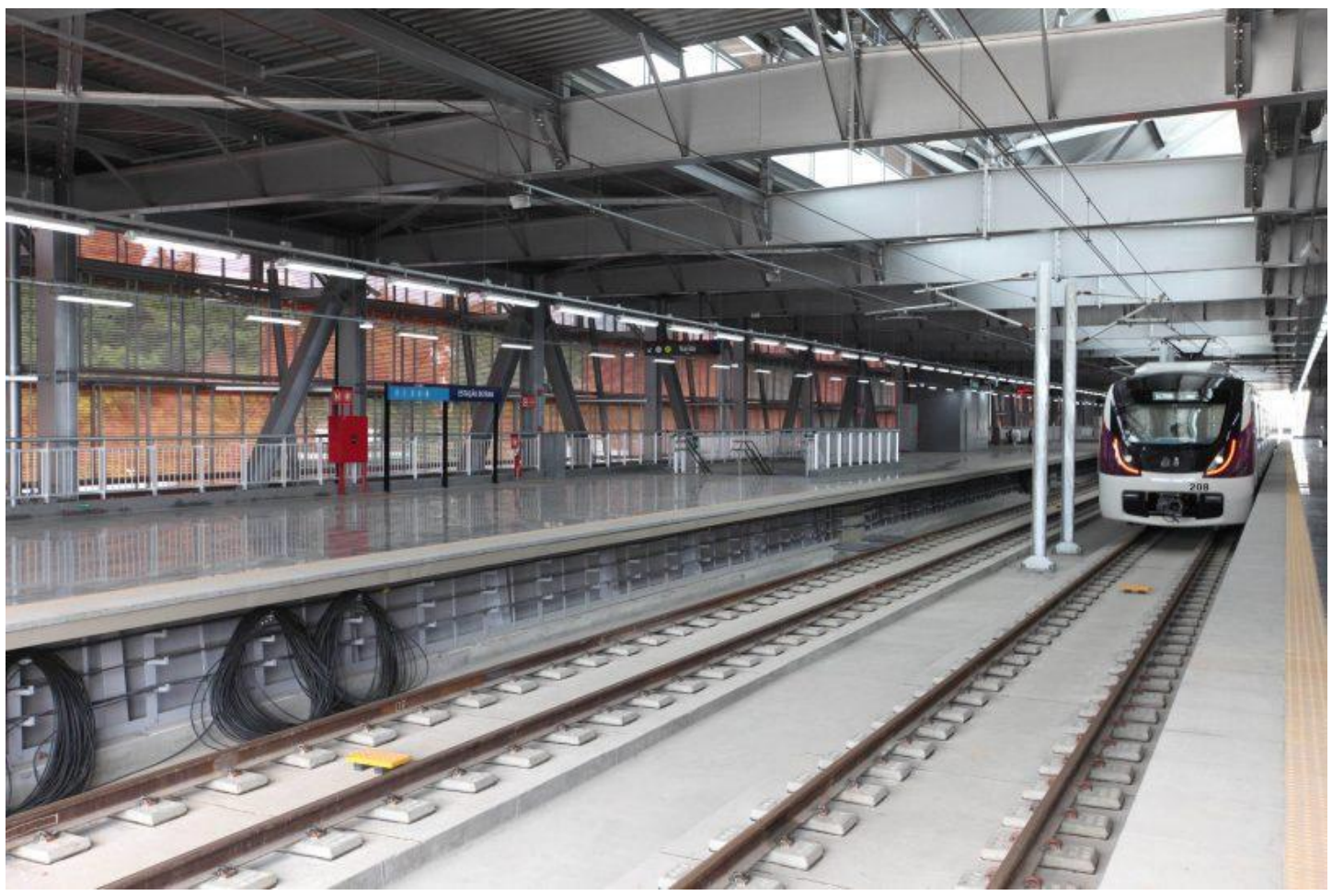

Fonte: Mapa Metro (2018)

A partir de 2016 o profissional conta que decidiram então transformar o BIM em um processo corporativo e, então, definiram como seria o seu processo de trabalho na Empresa 3. Para isso, os profissionais estudaram as experiências que tiveram com o BIM para criar o desenho do processo dentro da organização. Os colaboradores contam que estruturaram o BIM Execution Plan (BEP), baseado nas orientações do CIC (2010). Como o modelo é genérico, há a necessidade de realizar alterações sempre no início de cada nova obra. As informações devem ser preenchidas em conjunto com a empresa projetista, conforme comenta a engenheira.

Os fluxos que a empresa desenhou para o processo de trabalho com o 3D, o 4D e o 5D tiveram o auxílio da consultoria do projeto-piloto. O desenho do processo BIM está formado, mas ainda está em um procedimento de aplicação para a verificação da sua eficácia. Ele já foi aplicado na fase de elaboração de propostas, porém ainda não foi efetuado nas obras, porque não houve nenhuma nova desde a sua elaboração. Ainda nesse documento desenvolvido foi previsto um plano de comunicação e gestão, em que se antecipa três tipos de reuniões, sendo elas a de kick off, toda vez que a contratada começar uma modelagem, reuniões de 
coordenação durante o desenvolvimento do modelo e reuniões de apresentação para outras equipes, nas quais o modelo compatibilizado era apresentado para os interessados.

A profissional conta que, ainda nesse documento, constam os 12 usos definidos para a utilização na Empresa 3, diretrizes para modelagem, matriz de responsabilidades definindo quem recebe, quem modela, dentre outros aspectos, definição dos formatos de arquivos aceitos (IFC), das etapas do processo e atualização do modelo, sendo, basicamente, um documento que visa orientar as empresas contratadas para desenvolverem a modelagem.

A profissional opina que a obra escolhida não foi a ideal para ser o projetopiloto, porque além da alta complexidade evidente pela sua tipologia, havia também a dificuldade devido aos projetos em 2D estarem 10 anos defasados, a grande quantidade de revisões que estavam sendo desenvolvida, a modelagem em paralelo com a obra em andamento que estava sendo feita para poder tentar testar - BIM. Apesar disso, ela acredita que foi bom para eles poderem aprender o que funcionava, o que era necessário prever antes de aplicar o BIM em uma obra e o fluxo de trabalho ótimo para se trabalhar.

A partir de todas as experiências com o BIM, para transformá-lo em um processo corporativo, a área de Construção Virtual decidiu então realizar uma palestra em 2016 para que todas as áreas corporativas pudessem entender sobre o método, o que a área estava desenvolvendo e como isso afetaria o trabalho dos demais. Nessa palestra, a profissional conta que eles apresentaram diversas informações, começando pelos objetivos do departamento:

a) Capturar e identificar em Engenharia e Construção as práticas mais atualizadas de BIM, ou seja, estar em constante atualização do que o mercado está praticando, com a presença em eventos específicos e inovações relacionadas ao BIM;

b) Identificar os usos do BIM que estão sendo colocados em prática no mercado, tanto em nível profissional quanto as informações referentes às pesquisas acadêmicas; 
c) Realizar a capacitação dos profissionais internos em conjunto com o RH. Identificar e definir quais são as ferramentas que precisam prover treinamento, organizar esses treinamentos, desenvolver o planejamento da capacitação, identificar a demanda das obras e áreas corporativas e definir cronogramas de capacitação;

d) Apoiar a contratação de projetistas e parceiros técnicos, em relação ao seu conhecimento de BIM, ciência do processo e das ferramentas e informações relevantes a serem incluídas no contrato com eles;

e) Apoiar a alocação de profissionais técnicos internos em obras e projetos, utilizando as pessoas que foram capacitadas para os usos de BIM para outras obras e propostas para a disseminação do conhecimento internamente;

f) Garantir a qualidade dos modelos BIM, realizando a revisão e a auditoria dos modelos externos recebidos e desenvolvendo modelos internos com qualidade e seguindo os padrões da empresa;

g) Focar na implantação do BIM nas obras e nas propostas.

Após a apresentação dos objetivos da área, a engenheira conta que também foram apresentados os usos do BIM escolhidos para serem implantados na empresa, também identificados a partir do livro BIM Project Execution Planning Guide. Então os profissionais entrevistados apresentaram os 12 usos mapeados para a utilização da Empresa 3, sendo eles:

a) Estimar quantitativos (5D) para orçamento, planejamento, controle e compra (com LOD diferente para cada uma das situações);

b) Planejar o 4D com o auxílio de laser scanning e outras tecnologias para 0 mapeamento do existente ou do avanço;

c) Verificar a integração e compatibilização dos modelos;

d) Estudar a implantação e logística de canteiro;

e) Realizar projetos de apoio à implantação (Fôrma, Projetos de Canteiro, Estudos de Acesso, dentre outros aspectos);

f) Melhorar a visualização no desenvolvimento de propostas;

g) Auxiliar no desenvolvimento de metodologias executivas; 
h) Averiguar os ciclos produtivos;

i) Estudar a movimentação da terra e da rocha;

j) Mapear o controle de obra e verificar as interferências em obras lineares;

k) Prospectar negócios (propostas e projetos conceituais);

Para a identificação dos usos aplicáveis para cada novo projeto, a profissional conta que eles desenvolveram um documento chamado "Avaliação de Aplicabilidade", porque devido à grande quantidade de tipologias de projetos com os quais a empresa atua, é necessário identificar as aplicabilidades do BIM no início de cada proposta ou obra. Então, ao iniciar uma proposta deve ser realizada uma conversa com o responsável pela mesma, na qual ele deve responder a uma série de questões estruturadas em um Excel, para que os usos possíveis do BIM para aquela proposta/obra específica sejam identificados.

Nessa palestra, também explicaram o conceito sobre o BIM, o que estava acontecendo no mercado na época, como o uso estava crescendo e contaram sobre algumas experiências internacionais já desenvolvidas em infraestrutura com o uso do BIM. Abordaram também as ferramentas que eles utilizam em cada etapa de projeto, estudos e obra, sendo AutoCAD Civil 3D, Infraworks, AutoCAD Map, MapServer, 3D MAX, Navisworks, Revit, Solibri, Synchro. Existem ferramentas que são mais completas do que outras, possuem valores diferentes de licenças e usos mais específicos do que outros, então, na opinião da profissional entrevistada, é necessário analisar cada caso antes da escolha da ferramenta ideal a ser utilizada naquele projeto para evitar o uso e softwares complexos sem necessidade.

A profissional entrevistada indica que a Empresa 3 pretende utilizar o $\mathrm{BCF}$ para fazer a comunicação e a aprovação dos modelos. Esses softwares citados são utilizados também para desenvolverem alguns projetos feitos internamente pela própria área de Construção Virtual, como os Projetos de Apoio à Implantação e Estudos de Canteiros. Assim, estão também começando a desenvolver bibliotecas específicas para esses projetos que são desenvolvidos internamente, visando a padronização e a agilidade na atividade, conforme conta a engenheira. Com as ferramentas que eles utilizam, é possível realizar estudos e prever problemas antes de iniciar a obra, a partir da criação de vídeos e simulação de cenários, como citam os exemplos dos estudos de movimentação de guindastes e o posicionamento de equipamentos. 
A profissional conta que foram desenvolvidos planos de treinamentos para as equipes de obras e do corporativo, que começaram a acontecer, mas tiveram que ser interrompidos em 2017 devido aos problemas financeiros da Empresa 3. Em 2018, após o período de crise, a Empresa 3 retomou o plano de treinamentos que havia desenvolvido para tal equipe.

Apesar dos treinamentos, os colaboradores contam que encontram muita resistência na inserção do BIM no dia a dia dos profissionais, principalmente na área de obras. Isso se dá pelo pensamento constante de profissionais que questionam a nova forma de trabalho, sendo que a maneira que eles faziam já era boa na visão deles. Na opinião da profissional, muitos desses colaboradores não possuem a percepção de que antigamente eles possuíam mais tempo e mais recursos para o desenvolvimento dos projetos, mas agora a necessidade é de fazer os projetos em prazos menores, com custo reduzidos e pouca margem de lucro. Portanto, as empresas precisam mudar o jeito de fazerem para se manterem no mercado. A implantação do BIM nas obras da Empresa 3 é dificultada pela falta de compreensão do método, pelo custo envolvido com o treinamento do pessoal e por ficar dependente da vontade do gerente de cada obra, conforme pontua a entrevistada.

Com essa dificuldade em vista, após essa palestra, realizaram então um treinamento para gestores, gerentes, gerentes de obra, de planejamento e de engenharia, sendo que praticamente todos eles nunca haviam escutado falar sobre o BIM. Os profissionais relatam que foi um treinamento pesado em relação à carga horária e ao conteúdo, sendo quatro horas de muita informação, casos práticos, orientações sobre como a Empresa 3 atuaria com o método nas obras, entre outros pontos. O objetivo desse treinamento foi o de receberem o apoio dos gerentes nas obras, para evitar o ocorrido na obra piloto e alinhar as expectativas da empresa e do que seria implantado nos anos subsequentes. Apesar do treinamento, os profissionais acreditam que cada obra será uma nova implantação do BIM, sendo necessário que a área de Construção Virtual oriente, acompanhe e monitore por algum tempo, até os colaboradores adquirirem mais conhecimento sobre o método e aceitarem a nova forma de trabalho.

Além disso, a profissional relata a dificuldade que eles possuem em encontrar projetistas e parceiros técnicos que trabalhem em BIM, principalmente na área de infraestrutura. Ela indica que em alguns casos as empresas de projetos até utilizam alguma ferramenta de modelagem 3D, mas eles não possuem o conhecimento 
teórico e não possuem um processo BIM estruturado, sendo assim não têm a capacidade de entregar o produto esperado por eles. Em 2018 a área de Construção Virtual era composta por apenas duas pessoas, que realizavam toda a gestão do processo BIM na empresa, desenvolviam modelagens nos softwares Revit, Civil 3D e Infraworks, bem como o planejamento 4D e eram responsáveis pela manutenção do processo BIM na empresa, que ainda estava em fase de implantação.

Eles entendem que para os próximos projetos seria interessante criarem métricas de desempenho do produto desenvolvido, para conseguirem começar a medir o ganho que estão tendo com a aplicação do método BIM nas obras desenvolvidas. Além do BEP, existem alguns documentos sendo desenvolvidos pela empresa, os quais são disponibilizados para as projetistas contratadas para o preenchimento e o reporte à Empresa 3, com o objetivo de controlar o andamento do processo de modelagem, como, por exemplo, o Relatório de Discrepâncias e Planilha de Controle de Compatibilização.

O gerente conta que em 2018 a Empresa 3 levou a tecnologia para a obra, investindo em tablets e smartphones para garantirem o BIM em todas as suas operações. Com esse avanço, ele relata que os colaboradores envolvidos podem verificar os modelos 3D e 4D em tempo real e resolverem questões pontuais nas obras. Com esse esforço, os coordenadores da construção podem registrar os problemas identificados in loco e acionarem os profissionais do corporativo para buscarem soluções no projeto, evitando o atraso no cronograma e o retrabalho. $\mathrm{O}$ esforço da implantação do BIM nas obras da Empresa 3 continua sendo pela área de Construção Virtual, mas agora com todo o apoio do presidente dela.

A profissional entrevistada acredita que o fato de existir um procedimento corporativo definido não implica necessariamente na adoção dele por todas as obras e que esse é um dos maiores desafios da área, o convencimento da equipe da obra a utilizarem o procedimento BIM estabelecido na Empresa 3. Na opinião dos profissionais, o processo de implantação do BIM é longo e o seu amadurecimento é contínuo. Isso é algo que eles veem que poderia auxiliar no processo de adoção do BIM nas empresas e a exigência pelos clientes ou pelo mercado, como uma exigência regulatória. Os colaboradores acreditam que esse tipo de exigência começará a acontecer com o tempo, cada vez com mais frequência. 


\subsection{EMPRESA 4}

A Empresa 4 se trata de uma construtora multinacional brasileira que está há mais de 70 anos no mercado, atuando em mais de 40 países e trabalhando com projetos de infraestrutura, energia, mobilidade urbana, projetos industriais, dentre outros. Possui um quadro de funcionários composto por mais de 90 mil pessoas e já realizou quase 1000 projetos de engenharia.

Essa construtora é referência no mercado de infraestrutura, portanto, está constantemente buscando novas soluções para os seus negócios, com o objetivo de se manter no mercado nacional e internacional. A excelência operacional é uma busca constante no seu trabalho devido à necessidade de melhorar o desenvolvimento das obras complexas que realizam.

A empresa é dividida em três unidades de negócios e oito diretorias corporativas, conforme se pode ver na Figura 42 a seguir. Esse estudo de caso foi desenvolvido a partir de entrevistas com profissionais da equipe de propostas da Diretoria de Engenharia, sendo essa a área pioneira a decidir utilizar o BIM nos processos da empresa.

Figura 42 - Organograma macro da Empresa 4

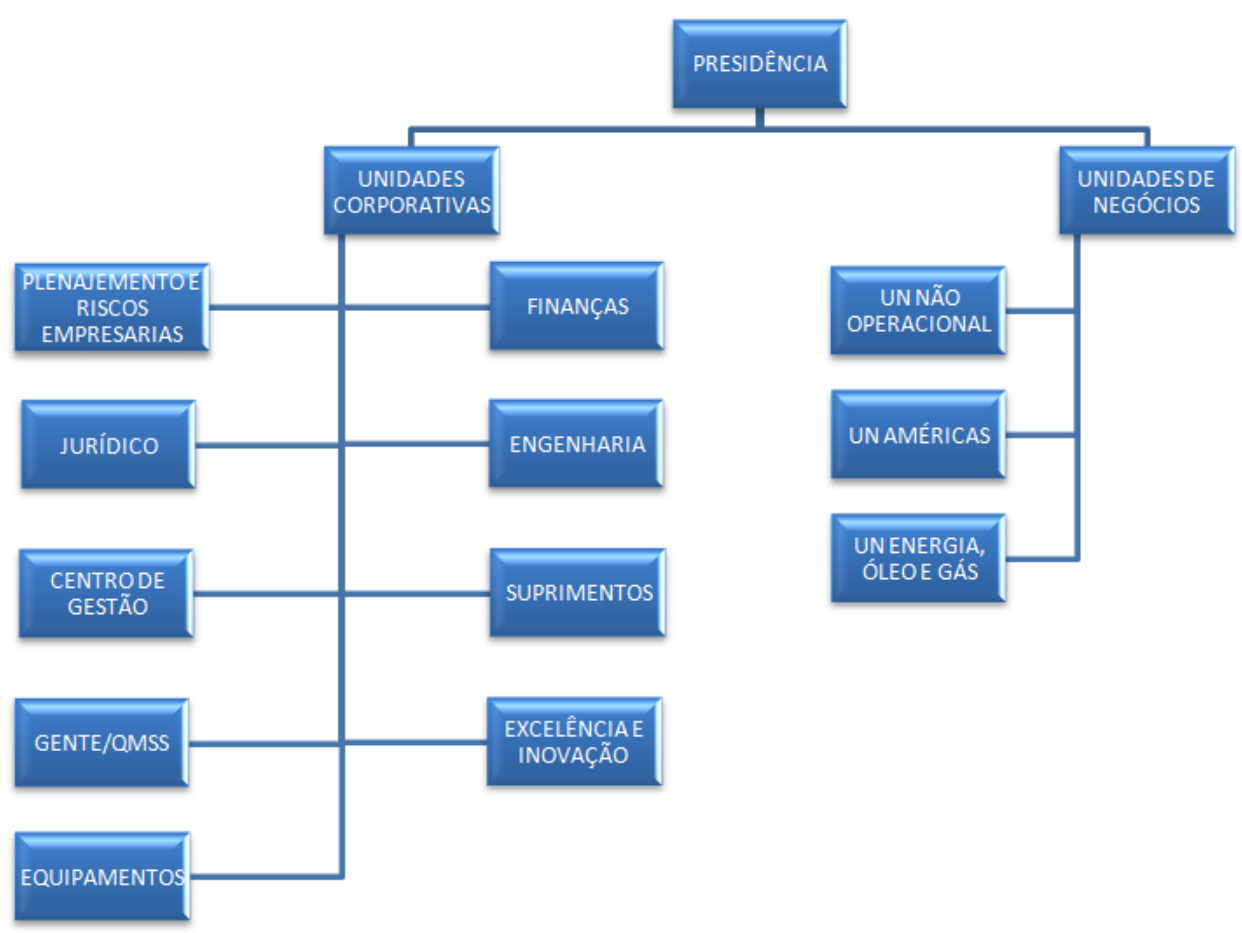

Fonte: A autora (2019) 
O estudo de caso nessa empresa se desenvolveu a partir de uma análise documental e entrevistas com diferentes profissionais da empresa, principalmente com as duas engenheiras que estão à frente do projeto de implantação do BIM na organização.

As profissionais entrevistadas contam que antigamente para melhorarem os processos de uma obra complexa, no início dela realizavam um esforço muito grande para estruturarem uma integração de processos a partir do uso da tecnologia, algumas vezes com as ferramentas chamadas de softwares BIM, porém, o que era feito não era o processo BIM. Esse esforço era realizado pontualmente com o objetivo de melhorar a gestão daquela obra, mas ocorria conforme a vontade do gerente da mesma. Ao final da obra, as experiências e o conhecimento se findavam com aquele projeto e com aqueles funcionários, não se tratando de um investimento da empresa, apenas uma iniciativa isolada de poucos profissionais.

Os colaboradores relataram que a motivação de adotar o BIM surgiu a partir do diretor de Engenharia que está sempre motivado pela busca de melhorias para a integração dos processos da empresa. O diretor é responsável, inclusive, pela área de propostas. Além de desenvolvê-las e precificá-las, esse setor também dá suporte de engenharia às obras, desenvolve diferenciais competitivos, propõem novos métodos, estuda diversos planejamentos, usa ferramentas para integrar os seus processos e está sempre buscando inovações e melhorias para a empresa.

Durante os seus estudos e pesquisas de novas soluções, no final do segundo semestre de 2017, o diretor começou a estudar sobre o método BIM e levou para a área de propostas da empresa o desafio de utilizar as ferramentas nos seus processos apenas dentro daquela área especificamente. A empresa já possuía todas as licenças da Autodesk, portanto não precisou fazer nenhum tipo de investimento em softwares naquele momento, começando, então, pela identificação de quais seriam os softwares que poderiam utilizar, como seria utilizado e quais ajudariam na automatização dos processos internos da área.

Conforme exposto, essa primeira experiência tomou um rumo completamente prático, sem o desenvolvimento do conhecimento e da ideia previamente, não havendo o desenvolvimento de um planejamento, de um desenho do fluxo e nem a identificação dos objetivos da implantação. Em novembro e dezembro de 2017, esse trabalho se transformou em um piloto dentro da área referente ao desenvolvimento de uma proposta de uma barragem e o objetivo do 
modelo era chegar até o 5D, passando pelo modelo 3D, com informações suficientes para a visualização do planejamento da obra pelo tempo e a possibilidade de extração de quantitativos para o desenvolvimento de um orçamento. Os colaboradores contam que a tentativa foi bastante ousada, pois os profissionais e a área nunca haviam trabalhado em BIM e já quiseram começar atingindo benefícios referentes a um nível de maturidade avançado. Como nesse momento o processo de implantação não foi bem estruturado, as profissionais relatam que foi apenas um momento para teste das ferramentas da Autodesk, sendo que a iniciativa nasceu e morreu rapidamente, porém serviu para perceberem que - BIM não seria algo simples de se implantar e que não se tratava de apenas softwares.

Figura 43 - Linha do Tempo 2015-2018

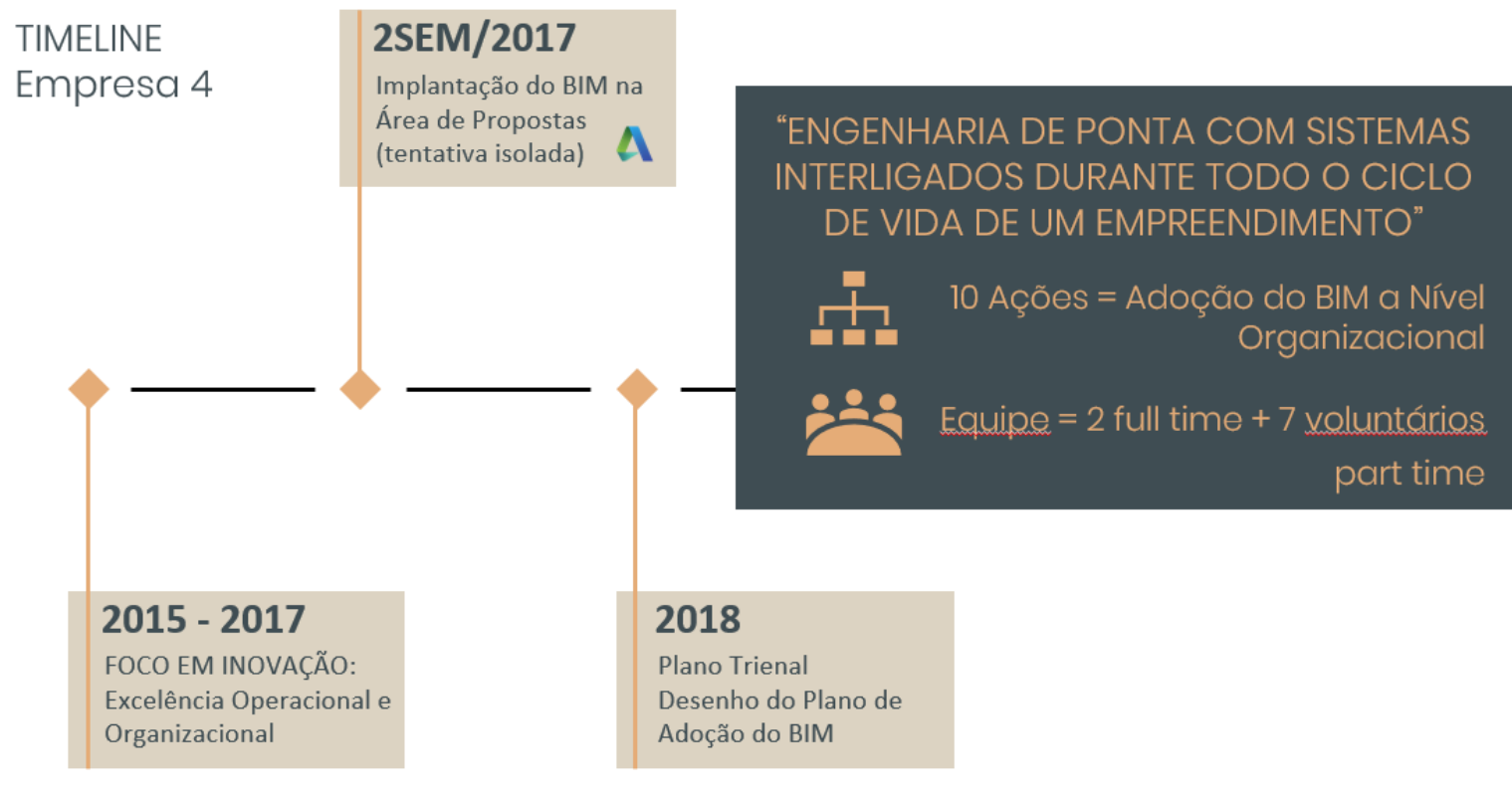

Fonte: A autora (2019)

As engenheiras explicaram que a cada três anos a empresa desenvolve um planejamento estratégico em nível organizacional e em janeiro de 2018 ocorreu a elaboração desses novos objetivos estratégicos da construtora para os anos de 2018, 2019 e 2020. Após a elaboração desse plano, os quatro diretores, também chamados de direcionadores estratégicos, ficam encarregados de desenvolverem ações para alcançarem os objetivos propostos. O diretor de Engenharia recebeu o objetivo organizacional de: "ter uma engenharia de ponta com sistemas interligados que conversem com todo o ciclo de vida de um empreendimento". A partir desse 
tema, ele e o presidente da construtora desdobraram o objetivo em 10 ações. Como esse propósito se relaciona diretamente com o BIM e a partir da experiência do piloto recente, entenderam então que essa seria a oportunidade de adotar o método BIM de maneira estruturada dentro da companhia, portanto decidiram que uma dessas ações seria o desenvolvimento de um plano de adoção do BIM dentro da empresa.

Figura 44 - Cronograma do Plano Trienal do BIM 2018, 2019 e 2020

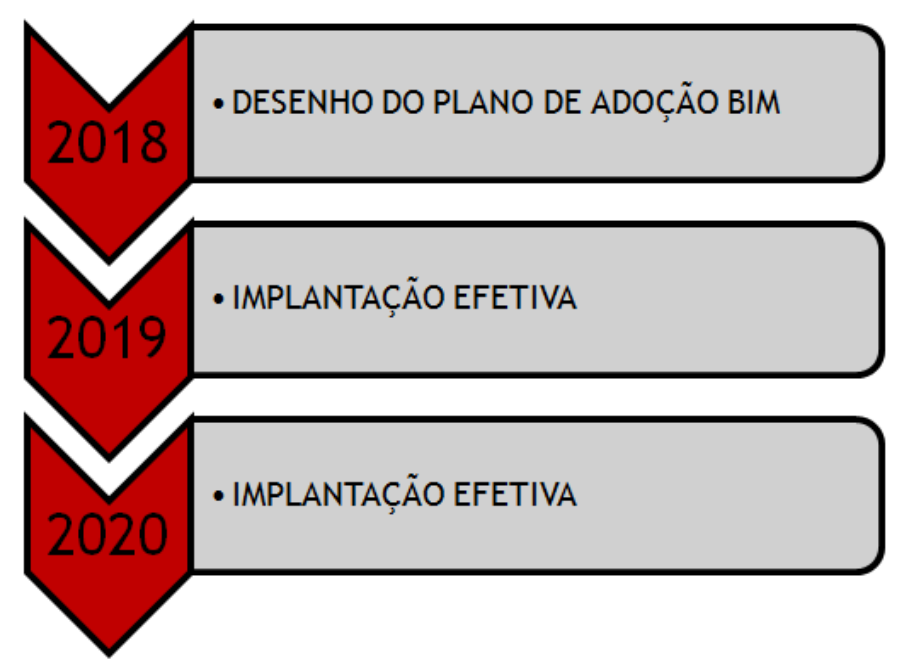

Fonte: A autora (2019)

O processo se iniciou com a construção de uma equipe focada na implantação do BIM na empresa. As duas engenheiras entrevistadas foram escolhidas para participarem em tempo integral dessas atividades. O objetivo inicial da equipe era o de estudar para entender o que era o método BIM, quais as possibilidades com a sua utilização, o que era necessário para atingir esses benefícios, o que serviria para a empresa e, ao final, consolidar um cronograma definindo as etapas para a adoção do BIM na organização. Então, os colaboradores contam que foi definido que em 2018 desenvolveriam o desenho do plano de implantação e nos dois anos seguintes realizariam de fato as ações para alcançarem esse objetivo. 
Nesse primeiro momento, a equipe incorporou mais sete colaboradores trabalhando parte do tempo para o projeto, sendo eles voluntários que se interessaram pelo projeto. Por serem voluntários, precisavam se dividir entre as entregas diárias das suas áreas e as ações necessárias para o desenvolvimento do processo de adoção do BIM. Os funcionários relatam que essa situação foi um pouco complicada devido à falta de tempo, porém para se organizarem agendaram reuniões, definiram prazos e entregáveis, portanto, o trabalho fluiu efetivamente nesse momento. As engenheiras entrevistadas acreditam que o BIM e qualquer outro projeto depende das pessoas acreditarem naquilo que estão fazendo e, por esse motivo, o voluntariado daqueles colaboradores foi muito importante, pois a motivação foi espontânea.

A equipe começou a estudar sobre o método, procurando informações em livros, artigos, webnars na internet, cursos e outros recursos. Realizaram benchmarking com o mercado para entenderem quem já estava utilizando o método, como, desde quando e o porquê. Realizaram nessa etapa muitas conversas interessantes, uma delas, inclusive, com o gerente da Empresa 1, que trouxe uma visão extremamente importante para que elas entendessem como seria vantajoso estruturar esse processo dentro da empresa, a importância em capacitar as pessoas e a necessidade de aculturação dos profissionais. Foram realizados benchmarkings com empresas projetistas, fornecedores, construtoras e clientes. Os colaboradores relatam que essa primeira etapa foi muito importante para a equipe perceber que esse projeto de implantação não seria algo pequeno como o teste de softwares que haviam realizado anteriormente. Os funcionários entrevistados perceberam que se tratava de algo muito maior, que traria mudanças significativas, como a modificação da cultura da empresa, dentre outras questões relevantes.

Após essa etapa de benchmark e assimilação do conteúdo inicial referente ao método BIM, a equipe desenvolveu um cronograma para o ano de 2018, dividindo-o em três etapas: a) Entendimento e Aderência; b) Investigação e Diagnóstico; e c) Road Map. 
Figura 45 - Cronograma BIM 2018

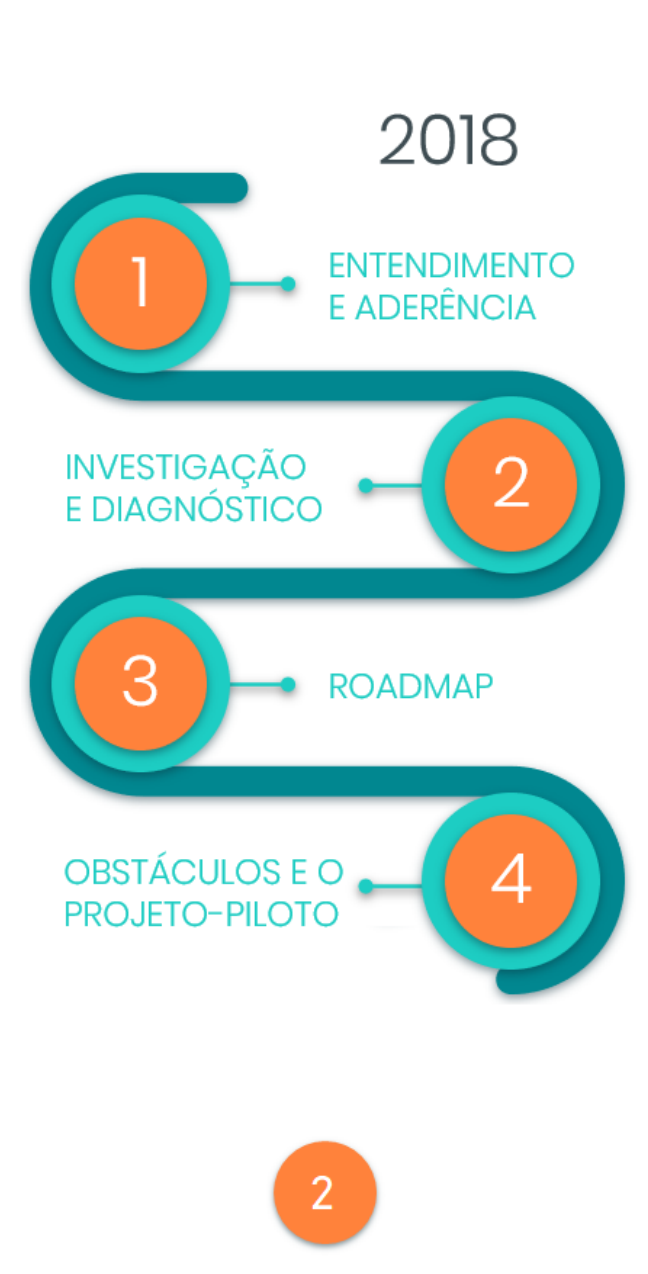

ANALISAR:

PROCESSOS INTERNOS

FORMA DE CENTRALIZAÇÃO E COMPARTILHAMENTO DA INFORMAÇÃO

MUDANÇAS PARA SUPORTAR O USO DO BIM NA EMPRESA

DESENHO DO AS IS E DO TO BE

INÍCIO DOS

PROJETOS-PILOTO
1

\section{ESTUDOS SOBRE O BIM}

LIVROS, ARTIGOS, WEBNARS, CURSO COORDENAÇÃO BIM, METRADO

PROFISSIONAL, TREINAMENTO INTERNO

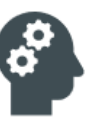

\section{BENCHMARKING}

EMPRESAS PROJETISTAS, CLIENTES, FORNECEDORES E CONSTRUTORAS

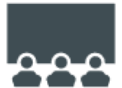

\section{PALESTRAS BIM}

PRIMEIRA PALESTRA: +200 FUNCIONÁRIOS, PALESTRAS A CADA 3 SEMANAS, CAPACITAR A ORGANIZAÇÃO, APRENDIZADO CONTÍNUO

\section{PLANO DE ADOÇÃO DO BIM}

$$
\begin{aligned}
& \text { ESTRUTURAÇÃO DAS } \\
& \text { INFORMAÇÕES }
\end{aligned}
$$

ORDEM DE IMPLANTAÇÃO NAS ÁREAS

CONSULTORIA E TREINAMENTO INVESTIMENTO E TEMPO CONTRATAÇÃO RESPONSÁVEL

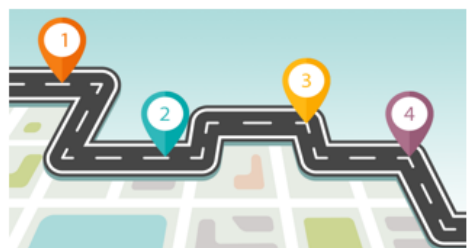

Fonte: A autora (2019) 
Essa primeira etapa deveria ter se estendido por três meses de duração, porém, os profissionais entendem que a coleta de informações e o estudo sobre 0 método deve ser constante e progressivo, portanto, o prazo não foi cumprido. Nesse primeiro momento realizaram estudos intensos e benchmarking com o mercado para entenderem sobre o BIM; desenvolveram também eventos para a capacitação da empresa referente ao tema, sendo o primeiro esforço com essa finalidade a realização de uma grande palestra em um espaço externo.

Nesse evento ocorreram quatro palestras de profissionais especialistas em BIM e compareceram mais de 100 profissionais fisicamente assistindo as palestras e mais de 100 acessos de servidores diferentes vendo-a pela intranet da empresa. Cada acesso poderia representar toda a equipe de uma obra.

Devido ao sucesso da palestra, a abundância de conteúdo para ser discutida referente ao método BIM e a importância em manter o assunto em evidência, decidiram então seguir realizando palestras menores a cada três semanas durante todo o ano para capacitarem os funcionários da empresa. No início, o projeto de implantação do BIM foi idealizado pela diretoria apenas para a área de propostas, porém devido ao resultado positivo dessas, o projeto foi reestruturado para ser realizada a adoção do BIM em todas as áreas da organização.

As profissionais mencionam que o objetivo dessa primeira etapa foi capacitar o grupo de trabalho e a empresa como um todo. Houve diversas abordagens para a capacitação da equipe do projeto e alguns membros começaram um curso presencial sobre a coordenação BIM, uma profissional que ingressou em um Mestrado na Escola Politécnica da Universidade de São Paulo para pesquisar mais a fundo sobre $o$ assunto e outros integrantes e fizeram um curso online à distância de BIM MANAGER da Zigurat. Posteriormente, o conteúdo programático desse último curso foi divido em dez aulas para compartilhar o conhecimento com as outras pessoas da equipe, sendo essas aulas realizadas semanalmente.

Os colaboradores contam que o propósito dessas diversas abordagens foi o de trazer o conhecimento de fontes variadas e aprender em conjunto, visto que o BIM se trata de uma novidade para a grande maioria dos funcionários da empresa. Além disso, a estratégia foi a de tentar vencer aos poucos a resistência dos profissionais à mudança e à adoção dos novos processos de trabalho e tecnologia. Outras metas foram instigar a curiosidade dos profissionais da organização, capacitar minimamente todos os colaboradores e fazê-los entender que essa 
mudança impactará na forma como eles trabalham de alguma maneira, inclusive daqueles das áreas de apoio as obras, como: Jurídico, Controle, Financeiro, dentre outros setores.

Essa primeira etapa "Entendimento e Aderência", estendeu-se por todo o ano de 2018 e se sobrepôs às outras duas etapas previstas no cronograma, visto que o aprendizado é contínuo. Os profissionais entrevistados relatam que o objetivo foi o de trazer o conteúdo e o entendimento do que é BIM para os funcionários da empresa e, com a constância da discussão, garantir a aderência do assunto em todas as áreas da companhia. O próximo passo dessa fase foi a identificação de palestrantes focados em determinadas áreas, convidando enfaticamente as pessoas daquele setor da empresa a participarem da palestra, para que esses colaboradores entendam melhor como o BIM pode ser utilizado no dia a dia dele e qual será esse impacto no seu processo de trabalho.

$\mathrm{Na}$ opinião das profissionais, essas palestras foram extremamente importantes para as equipes aceitarem melhor a inovação proposta, compreenderem os benefícios daquela mudança, quais seriam as alterações efetivas para o processo de trabalho delas e como o método BIM pode agregar no seu trabalho. Na opinião das engenheiras, se o profissional enxergar como o BIM pode influenciar positivamente as suas atividades é muito mais fácil e menos trabalhoso o serviço da equipe de implantação do BIM, uma vez que o próprio profissional anseia pela melhoria dos seus processos e agirá como o agente de mudança dentro da sua própria área em um segundo momento.

As profissionais da equipe do projeto de implantação contam que as palestras foram muito efetivas, conseguindo enxergar claramente em alguns profissionais a motivação e o interesse pela mudança que estava sendo proposta. Elas contam que um desses momentos ocorreu durante a palestra sobre padronização e a classificação do convidado Wilton Catelani, membro da comissão da ABNT que desenvolve a tabela de padronização da classificação das informações BIM, na qual o diretor de suprimentos da empresa participou ativamente da palestra, fazendo perguntas e anotações. Elas atribuem essa maior receptividade à mudança e à menor resistência dos profissionais aos trabalhos de motivação que vêm sendo realizados pela empresa há pelo menos quatro anos, incentivando os colaboradores a aceitarem as mudanças, a buscarem por inovações e a adotarem novas formas de fazer. 
As profissionais contam que há quatro anos a empresa vem fomentando a inovação e indicando que esse é o futuro da organização, o que começou com a criação de uma área de Excelência Operacional focada na filosofia de gestão Lean Production para auxiliar os processos e a integração da obra. Posteriormente foi criada a área de Excelência Organizacional focada em trazer inovações e soluções para as áreas corporativas e a empresa possui a área Excelência Inovação.

A segunda etapa do cronograma foi nomeada como Investigação e Diagnóstico. Após a compreensão teórica sobre o método BIM, esse foi o momento da equipe olhar para dentro da empresa e entender o que eles fazem e como, para tentarem identificar dentro dos possíveis usos do BIM quais se aplicariam para eles. Nesse momento, além da oportunidade de melhorarem os processos para a implantação do BIM, é possível também refletir sobre os as propostas existentes na organização para entender o porquê é feito daquela maneira e, possivelmente, identificar, também, outras melhorias que não tenham vínculo com o BIM. Esse período serviu principalmente para analisar como a informação é armazenada e transferida, para levantar as necessidades de mudança da estrutura da informação que terão que ser feitas para suportarem o uso do método BIM dentro das obras e da organização.

Para isso, o grupo de trabalho se propôs a desenvolver um material para passar em cada uma das áreas organizacionais da empresa, para apresentar um conteúdo explicativo sobre o método BIM, referente ao que é, o que faz, como faz, quais as mudanças, quais os impactos para o fluxo de trabalho, quais os benefícios, porque é importante para a empresa adotar o BIM, dentre outras questões. $\mathrm{Na}$ opinião dos profissionais entrevistados, essa etapa mais pessoal na qual conversaram com cada funcionário é bastante importante na garantia do entendimento de todos e deveria ter sido realizada na etapa 1 , porém, devido ao tempo e à maturidade sobre o conteúdo não foi possível.

Com base nessas conversas, será possível começar o desenho dos processos referente a como eles são hoje $(A S I S)$ e como eles entendem que deveriam ser a partir da adoção do BIM ( $T O B E$ ), sendo que os profissionais das áreas auxiliarão nessa atividade. Tendo em vista que quem conhece os processos e as atividades são os próprios colaboradores que realizam as tarefas todos os dias, o envolvimento deles nesse momento é crucial para a eficiência dessa etapa e maior motivação das equipes, na opinião das engenheiras. 
Esse trabalho em equipe unirá o que se sabe sobre o BIM da equipe do projeto e o conhecimento sobre as atividades diárias de cada funcionário. Isso concluirá em um maior entendimento e participação de cada funcionário das áreas operacionais e em um menor esforço por parte do grupo de trabalho BIM, que teria que entender detalhadamente cada processo de cada área, analisar e então propor como o BIM se encaixaria naquele cenário.

Como essa etapa foi referente à investigação, não realizaram transformações no processo de trabalho naquele momento, pois toda a informação coletada serviu de subsídio para o desenvolvimento da terceira etapa. Uma das melhorias necessárias para a implantação foi a reestruturação da informação interna da empresa, porque essa mudança daria suporte ao uso do BIM e, portanto, precisou ser viabilizada antes da implantação.

A primeira necessidade identificada foi a de melhorar o gestor de documentos da empresa e o desenvolvimento dessa melhoria já se iniciou. Agora estão sendo verificadas a necessidade de melhorar o Gestor de Materiais para utilizar nas obras e o Gestor de Planejamento. Então, tudo dentro da empresa que possui o papel de organizar, consolidar e armazenar informações foram analisados para verificar as melhorias necessárias para quando começassem a trabalhar com os modelos.

Ainda durante essa etapa, os profissionais contam que foram iniciados projetos-pilotos em obras e propostas para identificar as necessidades do que é necessário desenvolver nessas etapas, para que possuam estrutura suficiente para utilizarem o BIM efetivamente. Outra motivação para iniciarem os projetos-pilotos foi a demanda das obras complexas, que alegavam não possuir ferramentas eficientes para realizarem a gestão da obra e dos materiais. Além disso, o presidente da empresa demandou que os projetos-pilotos fossem iniciados ainda em 2018, para que a empresa começasse a ver a mudança ou as possibilidades na prática. A ideia foi de tirar o projeto do papel, conforme contam os profissionais.

Toda construtora possui grandes áreas dentro da empresa que dão suporte às obras, então existe uma rede muito grande por traz, com as suas diversas áreas que auxiliam a obra, independente da tipologia: termoelétrica; rodovia ou barragem; todas as áreas precisam dar suporte corporativo para esses projetos. Portanto, de acordo com os profissionais, a demanda dos projetos-pilotos surgiu com o objetivo de validar essas pequenas mudanças que estavam começando a acontecer corporativamente, para testar na prática o que estava sendo proposto, entender se 
funcionaria e então começar a fazer a retroalimentação e as trocas de informações, experiências e feedback entre o corporativo e a obra. Outro objetivo relatado desses pilotos é o de melhorar os processos internos das áreas de propostas e obras com o método BIM, para que o trabalho seja mais fluído, a partir da implantação de mudanças e validação com os pilotos.

Como a empresa construtora trabalha em uma das fases do ciclo de vida do empreendimento, sendo essa a de construção, quando já houve a concepção e o desenvolvimento do projeto. Muitas definições que impactarão a obra já foram definidas anteriormente por empresas que muitas vezes não tinham a expertise do campo, conforme relata a engenheira.

Figura 46 - Representação do ciclo de vida de um empreendimento típico da construção civil

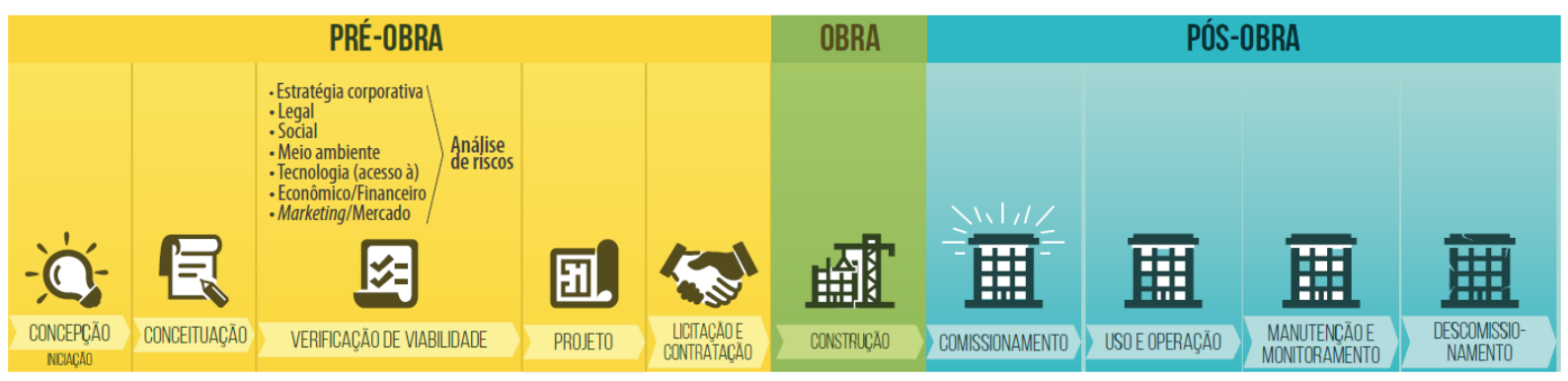

Fonte: CBIC (2016a)

Os profissionais afirmam que, por esse motivo, outro grande desafio que possuem é o recebimento dos projetos em 2D, o que causa um esforço inicial imenso para a equipe que o recebe, uma vez que terá que desenvolver toda a modelagem detalhada para depois conseguir utilizar o modelo para o planejamento da obra (4D) e para a extração de quantitativos para compras na obra (5D). Nesse caso, pontuam que o problema é o tempo, sendo que muitas vezes recebem os projetos conforme a obra está em andamento ou muito próximo do início, o que não permite a modelagem em tempo hábil antes do início dela. Eles indicam que esse é o maior desafio deles: entender como esse degrau entre o projeto e a obra pode ficar menos impactante nos processos da empresa.

O primeiro projeto-piloto desenvolvido se trata de uma obra industrial, a qual a empresa projetista já forneceu o modelo 3D do projeto da obra. Por esse motivo esse projeto foi escolhido. Os profissionais contam que o uso do BIM é mais comum em obras industriais do que outros tipos de obras, devido à sua complexidade. Portanto, essa projetista normalmente já desenvolve os seus projetos em 3D e 
entrega o modelo, apesar de nesse caso esse serviço ter sido contratado. Além disso, eles destacam que a maneira mais fácil de operar com obras em BIM seria que a demanda viesse dos clientes que contratam a projetista e as construtoras, porque assim eles podem garantir que a construtora receba o insumo para trabalhar pautada no planejamento e na extração de quantitativos com mais facilidade e agilidade.

A Empresa 4 ainda não tentou operar um piloto em uma obra na qual o modelo 3D não foi fornecido pela projetista, porque os profissionais contam que eles ainda não possuem um fluxo e nem um plano de ação para esse caso em específico. Internamente, na empresa, eles possuem profissionais que modelam e poderiam desenvolver esse esforço inicial de passar o projeto em 2D para o 3D, porém ainda não possuem muita experiência e a empresa não tem um processo corporativo que preveja essa atividade. Então esse tipo de situação, que acontece com frequência para as obras, ainda está sem destinação pela empresa, conforme relata a engenheira.

Os profissionais explicam que na maioria das vezes não são eles quem contratam o projeto, portanto eles não possuem tanto essa liberdade para escolherem a projetista que trabalha em BIM e que pode fornecer algo nesse sentido. Porém, para as poucas obras que a empresa também contrata o projeto, eles já estão desenvolvendo as informações que deverão ser incluídas nesses contratos, para que a organização responsável desenvolva o projeto em BIM.

O projeto-piloto, apesar de ter sido entregue o modelo 3D, o modelo não veio formatado da maneira necessária para a equipe da Empresa 4 trabalhá-lo para outras finalidades, como o 4D e o 5D. Desse modo, todas as vezes que a equipe de implantação do BIM tentava implantar algum uso diferente na obra, eles identificavam a dificuldade e não conseguiam testar. Em vista disso, uma das engenheiras da equipe interna da empresa foi a responsável por adaptar esse modelo de maneira que ele pudesse ser utilizado para desenvolver os outros usos. Após esse esforço interno, as profissionais contam que foi possível desenvolver o planejamento 4D detalhado da obra com o modelo 3D recebido, conseguindo realizar até a emissão de folha de tarefas para os encarregados. Durante essa experiência foram alocadas três pessoas da equipe BIM na obra em tempo integral, treinando a equipe de obra. Após essa semana o contato foi diário para o acompanhamento, a resolução de problemas e o suporte à obra. 
Apesar da dificuldade encontrada, a equipe conta que conseguiu enxergar isso como uma oportunidade de mapear as deficiências do modelo 3D recebido e, a partir disso, definiram quais são as informações mínimas que o modelo deve conter na hora de contratar a empresa projetista. Portanto, os projetos-pilotos estão servindo como testes para realmente identificarem as necessidades da empresa e os requisitos para a contratação, sendo previstos nos contratos e fazendo parte do BEP da empresa. Os profissionais também contam que precisarão aprender e automatizar o processo de recebimento do modelo e verificação de inconsistência ou falta de informações.

Entretanto, os profissionais entrevistados afirmam que ainda existem esforços muito grandes a serem desenvolvidos, tanto internamente quanto do setor da construção civil brasileiro, para que as empresas projetistas tenham a expertise suficiente e entreguem os modelos, conforme a necessidade das obras, com informações adequadas e organizadas. Internamente, os colaboradores contam que identificaram a necessidade de trazerem um profissional experiente no mercado para liderarem esse projeto de adoção do BIM, fazendo a contratação do profissional para desenvolverem as próximas etapas de adoção do método na empresa.

Já na área de propostas, faz parte do processo interno da Empresa 4 desenvolver um modelo 3D para testar os cenários de diferentes metodologias construtivas, realizar simulações do planejamento físico-temporal da obra e pequenos estudos para agregar valor às propostas. As profissionais contam que esse processo já foi implantado nessa área porque normalmente eles já possuíam um esforço de análise grande, porque geralmente recebiam os projetos 2D em PDF e precisavam transformá-los em DWG para poderem gerar algum material. Então, ao invés de transformarem em 2D agora vão direto para o modelo 3D básico. Com essas experiências eles já estão conseguindo também identificar o que será necessário solicitar em um modelo para evitar o retrabalho da equipe interna.

Os próximos passos da empresa são os de intensificar os pilotos, aumentar em quantidade e identificar as necessidades das obras e das propostas. Com a identificação das dificuldades e o mapeamento de oportunidades eles entendem que será a melhor maneira de conduzir a implantação do BIM na empresa e agregar valor ao seu produto final, facilitando o trabalho dos colaboradores com o uso da tecnologia. Os pilotos servirão também como validação dos processos que estão 
sendo alterados na estrutura corporativa, ou seja, em toda a esfera de apoio para as obras e propostas. Os profissionais contam que para que isso seja efetivo, a retroalimentação dos processos, a redefinição dos contratos e os treinamentos são essenciais. Apesar de terem chegado na etapa do Roadmap, ou seja, do desenho do processo de adoção do BIM, a empresa optou por não revelar mais informações, visto que o documento estava em desenvolvimento e possuía diversos dados sigilosos. 


\section{ANÁLISE DOS RESULTADOS}

Neste capítulo serão apresentadas as análises dos resultados parciais das quatro empresas que fizeram parte dos estudos de casos dessa pesquisa e a sua relação com a bibliografia abordada. Como o processo de adoção do BIM é progressivo e o tempo deste estudo é finito, os resultados registrados foram do início do processo até 2019.

\subsection{Empresa 1}

\subsubsection{BIM da GPR}

A motivação da adoção do BIM na Empresa 1 iniciou pela interação dos profissionais da área com eventos de inovação, que começaram a conhecer sobre o método, porém o processo de implantação só começou dentro da organização quando a alta hierarquia foi convencida do potencial representado pelo BIM e decidiu investir (CÂNDIDO; ABREU, 2002; SILVA; GIL, 2013; EASTMAN et al., 2014). O apoio da diretoria das empresas é essencial na implantação de qualquer inovação, principalmente pela necessidade de investimento e pelo impacto que a mudança traz nos negócios (CATELANI; SANTOS, 2016; CÂNDIDO; ABREU, 2002).

O processo de adoção do BIM na empresa iniciou pela área responsável pelos projetos básicos, os quais teria maior impacto por serem o início do ciclo de vida do projeto, conforme se pode evidenciar no Gráfico 4. A primeira ação para esse fim foi a contratação de um profissional experiente no método, com o objetivo de trazer o conhecimento do mercado para dentro da empresa e compartilhar o conhecimento prático e teórico com os demais colaboradores da organização. Essa estratégia adotada pela Empresa 1 de obter conhecimento externamente é reconhecida por Silva e Gil (2013).

Entretanto, para a condução desse tema não foi realizado nenhum planejamento prévio, nem a definição das etapas as quais a empresa teria que seguir para efetivamente adotar o BIM nos seus processos, conforme evidenciada a importância por Cândido e Abreu (2002), Silva e Gil (2013), Eastman et al. (2014), CBIC (2016b), PMI (2013), MDIC (2018c) e CBIC (2016a). No ano seguinte de 
contratação do profissional, a empresa iniciou o seu primeiro projeto-piloto com a aplicação do método, mesmo sem a estruturação da implantação interna.

Consequentemente, nesse primeiro ano houve a necessidade de realizar treinamentos internos com toda a equipe para que entendesse a nova maneira de trabalho que seria implantada na área, conforme a necessidade evidenciada por CBIC (2016b), PMI (2013) e CBIC (2016b). Além disso, com o intuito de contratar uma empresa para desenvolver o projeto, os profissionais da Empresa 1 identificaram a necessidade de definir o que eles esperavam do produto final a ser entregue.

Desse modo, a equipe interna desenvolveu um Manual de Diretrizes para servir de orientação às empresas contratadas com definições específicas para a padronização dos projetos, simplificação dos processos de validação dos projetos, comunicação com os fornecedores, dentre outras informações relevantes. A preparação da Empresa 1 por esse material se deu na definição das questões técnicas esperadas; softwares pré-definidos para garantir a interoperabilidade entre as empresas envolvidas no projeto e o plano de execução para o alinhamento de expectativas, papeis e responsabilidades.

Apesar da Empresa 1 ter a percepção das deficiências dos projetos em 2D, pela sua experiência há anos, é importante lembrar que o projeto em 3D também pode ser ineficiente. Se as soluções apresentadas não forem coerentes, se o projeto estiver bem resolvido, com toda a verificação de incompatibilidades, apenas com os usos BIM realmente necessários e viáveis para aquele projeto, pode ser que o produto também não tenha a qualidade esperada (CIC, 2010).

Por esse motivo, ao contrário do que muitos pensam, o BIM não é a solução dos problemas de qualquer empresa contratante, projetista ou construtora de qualquer segmento da indústria AEC. O BIM é um método que precisa ser entendida e aplicada da maneira correta, com o planejamento e a preparação dos colaboradores para realmente funcionarem e entregarem os benefícios prometidos.

Apesar dos diversos usos existentes do BIM elencados na bibliografia como de Kamardeen (2010), Smith (2013), CBIC (2016d) e CIC (2010), a Empresa 1 optou por começar adotando apenas o 3D, para então seguir para os próximos usos apenas quando esse estivesse totalmente compreendido. Isso demonstra o conhecimento sobre as fases de maturidade do BIM, no qual há a necessidade de alcançar um nível para seguir para o outro (SUCCAR; KASSEM, 2015). 
O projeto-piloto é uma fase muito importante no processo de adoção do BIM, conforme descrito na bibliografia de CBIC (2016b). Por esse motivo ela deve ser conduzida de uma maneira estratégica, com planejamento prévio e estudo das necessidades. Essa bibliografia ainda define que a complexidade do projeto-piloto deve ser média e, de acordo com as obras frequentemente realizadas pela organização, orientação que foi seguida corretamente pela Empresa 1, mas como os produtos finais das instituições de infraestrutura costumam ter complexidade elevada, o planejamento deve ser ainda mais minucioso.

Além disso, a companhia possui alguns entraves para a contratação de projetos, principalmente com requisições específicas, como a exigência de ser desenvolvido em BIM, com a entrega do modelo, dentre outras solicitações. Isso ocorre uma vez que as contratações da empresa são por licitação, buscando os menores preços e não podendo restringir o mercado das organizações a serem contratadas.

A comunicação entre a equipe contratante e a contratada foi intensa desde 0 início do projeto, com o desenvolvimento em conjunto do plano de execução BIM e durante o processo de projeto com o emprego do formato BCF para as revisões. A importância da comunicação entre os envolvidos nos projetos BIM e a simplificação dela é evidenciada por Manzione (2013), Eastman et al. (2014) e CBIC (2016f).

Para o projeto-piloto, o profissional identificou a necessidade de criar métricas para justificar a adoção do BIM, porque existe uma necessidade muito grande de mostrar valor em todo investimento feito pela empresa, principalmente em companhias públicas que possuem orçamentos ainda mais restritos e pela mudança da alta hierarquia, que acontece ao longo dos anos. Além disso, a métrica foi desenvolvida também para convencer os colaboradores da companhia, visto que enfrentam uma grande rejeição devido à radical proposta de mudança no processo de trabalho existente hoje (SILVA; GIL, 2013; CÂNDIDO; ABREU, 2002).

Após o recebimento do projeto da contratada e a etapa de validação de cada disciplina internamente, o responsável classificou os tipos dos comentários realizados pelos engenheiros revisores e no Gráfico 3 identificou um crescimento de mais de 6 vezes maior de inconsistências encontradas no projeto em BIM do que em projetos convencionais. Esse fenômeno aconteceu devido à clareza que o modelo 3D traz de todos os projetos ao mesmo tempo, as incompatibilidades que conseguem ser antecipadas com a compatibilização e a verificação da 
construtibilidade e viabilidade da operação e manutenção dessas dependências, alguns dos benefícios do BIM evidenciados por Abdelmohsen (2012), Mordue, Swaddle e Philp (2016), Azhar (2011), CBIC (2016a), McGraw Hill Construction (2014) e CBIC (2016f).

Essa maior percepção permite prever questões antes de se tornarem um retrabalho na etapa de projeto executivo, no qual o esforço de mudança do projeto seria muito maior ou um retrabalho na etapa de obras em que o custo dessas incompatibilidades poderia impactar o orçamento da obra consideravelmente, conforme Gráfico 4. Esses são problemas enfrentados pelos diversos stakeholders da cadeia produtiva da engenharia civil, conforme cita Ferreira e Zancul (2016).

A decisão tomada pela empresa de não criar uma biblioteca completa para os elementos utilizados nas obras da Empresa 1 foi estratégica devido à rotatividade de elementos que podem ser trocados ao longo dos anos de fornecedores, dentre outros. Portanto, teriam um grande retrabalho toda vez que houvesse alguma alteração. Dessa maneira, optaram por inserir no modelo objetos genéricos, de modo que o que eles precisam, como uma porta ou algo semelhante, seja representado genericamente, para posteriormente realizarem a compra e instalarem na obra a peça real aprovada.

Os treinamentos nessa área continuam sendo internos, a partir do compartilhamento do conhecimento, visto que a Empresa 1 não possui recursos para investir neste momento, o que possui dois lados: o nivelamento do conhecimento entre a equipe interna; porém, ao mesmo tempo, a equipe deixa de adquirir novos conhecimentos sobre as ferramentas e os processos do mercado. Ainda sobre a questão do investimento, é necessário que as empresas invistam em hardware para que os softwares já adquiridos continuem com a performance desejada.

Alguns dos benefícios identificados pelos profissionais da Empresa 1 foram: A antecipação da tomada de decisões sobre os projetos e sobre as soluções construtivas para a etapa na qual existe uma maior capacidade de alteração do projeto com pouco impacto e muito ganho posterior, de acordo com CBIC (2016a) e Biotto, Formoso e Isatto (2012). Antes disso, os projetos que eles recebiam em 2D eram insuficientes em relação às definições, ao conteúdo e às soluções construtivas para o projeto. Havia a diminuição de retrabalho, visto que diversos problemas agora são identificados na etapa de compatibilização de projetos, 
diminuindo, assim, o tempo de revisão, frustrações e problemas nas fases subsequentes de projeto executivo e obra, conforme se pode observar no Gráfico 4.

A melhoria nas reuniões também foi um benefício identificado pela Empresa 1 , pois a visualização clara e um melhor entendimento do modelo simplificaram os debates sobre as soluções entre as áreas e stakeholders envolvidos, vantagem do processo BIM evidenciada por Manzione (2013), Eastman et al. (2014) e CBIC (2016f). Além disso, os setores que antes não eram envolvidas nessa etapa de revisão do projeto básico, começaram a ser nessa etapa para anteciparem necessidades.

A Empresa 1 identificou que o processo de revisão dos projetos foi simplificado e se tornou mais rápido com a possibilidade de vários colaboradores trabalharem no mesmo modelo ao mesmo tempo (MORDUE; SWADDLE; PHILP, 2016; EASTMAN et al., 2014; CBIC, 2016F), facilidade de visualização das incompatibilidades (EASTMAN et al., 2014; CBIC, 2016a), simplificação e maior clareza na comunicação com o projetista.

Ao relacionar o Gráfico 3 com o Gráfico 4 é possível ver que em menos tempo de revisão dos projetos, a quantidade de comentários nas revisões foram significantemente maiores, ou seja, isso demonstra que o BIM permite agilizar o processo de revisão das empresas contratantes e ao mesmo tempo permite aos profissionais anteciparem questões que só seriam vistas em outras etapas do processo. Isso é claro para o profissional entrevistado e é relatado pela bibliografia de Mordue, Swaddle e Philp (2016), de Eastman et al. (2014) e da CBIC (2016f).

Além do tempo e da quantidade de comentários, com os filtros da natureza dos comentários foi possível também verificar que no projeto sem BIM os revisores acabam focando muito na questão da apresentação dele. A maior quantidade dos comentários foi em relação à representação gráfica e em relação a folha e à documentação. Enquanto isso, no projeto com BIM, além do aumento na quantidade de comentários, mais da metade deles focaram na qualidade do projeto, sendo os comentários sobre a natureza dele. 


\subsubsection{Inovação BIM}

Há alguns anos o BIM vem se tornando o novo método que vai revolucionar a indústria AEC, conforme acredita CBIC (2016b). Na Empresa 1, a falta de preparação da implantação do BIM em uma área da empresa e incentivos governamentais motivaram o desenvolvimento de um processo de adoção do BIM corporativo, com uma grande etapa de planejamento prévio. O Plano de Negócios de 2016 da empresa definiu que o BIM deveria se tornar um processo corporativo, ao invés de focado em apenas uma área da organização. Com isso, iniciaram a adoção do BIM, com o objetivo de disseminar e maturar o processo. Essa iniciativa iniciou cinco anos depois dos primeiros colaboradores trazerem pela primeira vez 0 tema até a empresa e três anos depois do início da implantação do BIM na GPR. Isso demonstra o quanto o processo de adoção do BIM é demorado, principalmente quando não existe o correto direcionamento e o investimento necessário para essa finalidade.

Para esse grande projeto corporativo a empresa decidiu envolver diversas áreas, selecionando para o comitê membros de todo o organograma da empresa, o que foi bom para dar visibilidade ao projeto e engajar todas as áreas da empresa. Apesar desse grande passo da empresa em direção à implantação do BIM na organização, é possível ver que isso só se iniciou devido à uma demanda presidencial, sendo muito difícil conseguir adotar o processo BIM sem o apoio da alta hierarquia, conforme necessidade evidenciada por Eastman et al. (2014).

Outro ponto interessante da adoção do BIM na Empresa 1 foi a abordagem em relação ao tema, em que apesar das questões claras como hardwares, softwares e processos, eles destacam a maior importância para as pessoas, o que vai ao encontro do que é definido pelos autores Cândido e Abreu (2002). Eles entendem que é crucial romper a barreira da rejeição à mudança e ao mesmo tempo mostrar o valor para cada profissional conseguir aceitar a inovação de uma maneira mais natural, conforme descrito na bibliografia.

Então o comitê iniciou esse projeto de adoção do BIM na empresa com palestras para familiarizar os colaboradores com o método, o que gerou uma série de benefícios, como profissionais buscando pós-graduação e cursos sobre o tema como iniciativa própria, o que demonstra uma abertura maior para a aceitação e o aprendizado. Isso é fundamental em uma organização tão grande quanto a Empresa 1, visto que o esforço de implantação em cada área será grande, mas com 
profissionais motivados com o tema, eles podem ser os próprios agentes de mudança dentro das suas áreas, diminuindo o esforço do comitê de implantação.

Ainda com o objetivo de fomentar o BIM nas pessoas, para o nivelamento do conhecimento, a Empresa 1 reuniu uma variedade de temas que o BIM abrange, justamente para os colaboradores conseguirem ver a pluralidade de possibilidades existentes com o uso do método. Os resultados desses esforços foram evidentes entre os das respostas coletadas na primeira pesquisa e realizada antes do início das palestras e na segunda feita após.

As pessoas compreenderam que o BIM não é apenas projetos em 3D ou um conjunto de softwares, em concordância com Succar e Kassem (2016), Eastman et al. (2014), Mordue, Swaddle e Philp (2016), Abdelmohsen (2012) e CBIC (2016a), mas sim um processo abrangente de todo o ciclo de vida do empreendimento. Os autores conseguiram compreender qual é o papel deles nesse processo de adoção do BIM na empresa, quais são os potenciais benefícios da implantação do BIM, concordaram que o BIM deve ser implantado nos projetos da organização e começaram a compreender melhor sobre os termos, envolvendo o método. Essa importância da compreensão real do BIM é exposta por Eastman et al. (2014) e CBIC (2016a)

Apesar desse esforço, não foi possível atingir todos os colaboradores da empresa e nem todas as áreas. A organização depende do compartilhamento do conhecimento entre os colaboradores, porém como o método de trabalho ainda não mudou, existe ainda um risco muito grande desse esforço cair no esquecimento pelos profissionais.

Já o segundo esforço realizado pelo comitê de adoção do BIM foi um workshop para entender como o método poderia auxiliar em cada área da empresa, visto que nem todos os usos deveriam ser utilizados em todas as organizações ou projetos, porque eles devem ser específicos para os resultados esperados. Como os líderes não possuíam o conhecimento do trabalho de cada uma das áreas da companhia, eles resolveram incentivar os profissionais que participaram das palestras e entenderam sobre o BIM a trazerem essa informação para eles.

Porém, essa iniciativa não foi bem planejada devido ao momento do fechamento do ano pelo qual a empresa estava passando, o que permitiu que fossem levantados durante o workshop diversos pontos de melhoria na Empresa 1 de maneira abrangente, o que não possibilitou uma análise ao final da experiência 
e um desperdício do esforço. A falta de foco e a necessidade dos profissionais se dividirem com outras demandas da organização faz com que o tempo de adoção do BIM e os resultados não sejam aqueles esperados.

O profissional responsável pela implantação do BIM tem a percepção de que se o plano de adoção nessa empresa seguir no mesmo ritmo, ele levará mais de 10 anos para se concluir, tendo em vista que ele é progressivo nas áreas, ao invés de simultâneo, conforme desenhado pela Empresa 1. Então, se a área de projeto executivo não passar pela implantação do BIM e concluir, a área de obras também não inicia nem operações, nem manutenção, nem as outras áreas. Apesar do projeto ter começado em 2016, apenas em 2018 o comitê definiu os objetivos do BIM na empresa e, em seguida, foi feita a identificação dos usos a serem adotados, para então definirem as áreas em que seriam implementadas. Após a definição de todo esse macroestudo e a aprovação do orçamento necessário, as implantações em cada área se iniciarão. Portanto é claro que será um processo longo na empresa, que só terá resultados se a alta hierarquia continuar com esse foco e investir nesse fim.

\subsection{Empresa 2}

A Empresa 2 iniciou o seu processo de adoção do BIM pela contratação de uma consultoria para dar treinamentos sobre as ferramentas aos colaboradores. Devido a uma ausência de conhecimento de todos os envolvidos nesse processo, isso os levou a pensar no BIM como apenas a utilização de softwares, o que vai contrário da constatação dos autores Succar e Kassem (2016), Eastman et al. (2014), Mordue, Swaddle e Philp (2016), Abdelmohsen (2012) e CBIC (2016a). Além do treinamento nas ferramentas ser superficial e não fornecer o conhecimento necessário sobre o processo BIM para os colaboradores, o investimento também é facilmente perdido com a rotatividade dos profissionais. Durante o estudo de caso foi possível perceber a superficialidade do conhecimento sobre o que o BIM representa e quais as necessidades e esforços mínimos necessários dentro da empresa para torná-lo um processo corporativo, o que pode gerar frustrações e uma implantação que quase não traz benefícios para a organização.

A motivação dentro dessa companhia surgiu devido aos problemas recorrentes na indústria $\mathrm{AEC}$, como os erros de projetos, retrabalho, aditivos, entre 
outros, sendo alguns deles citados por Ferreira e Zancul (2016). Começaram então a estudar sobre o tema em 2012, mas só em 2014 contrataram os treinamentos iniciais e em 2015 começaram o primeiro projeto-piloto. Apenas em 2017 a Sala BIM ficou pronta na empresa, o que ocorreu cinco anos após o início da adoção do BIM na mesma. Assim como a Empresa 1, a situação da Empresa 2 demonstra o quanto é moroso o processo de inovação dentro das organizações públicas. Ademais, o local fica ocioso devido à falta de projetos internos ou validações externas, então o grande investimento em softwares e hardwares, o que aparentemente não possuiu muito uso até o momento.

A consultoria contratada sugeriu o procedimento de implantação baseado na Sala BIM, que consiste em colocar todos os envolvidos no projeto em uma mesma sala para trabalharem em conjunto. Portanto, a Empresa 2 entendeu que seria a melhor forma de adotar o BIM e seguiu dessa maneira. O conceito de Sala BIM vai contra o processo de trabalho do BIM, tendo em vista que a proposta do método é justamente o processo colaborativo entre os envolvidos sem a necessidade de estarem no mesmo ambiente (MORDUE; SWADDLE; PHILP, 2016; EASTMAN et al., 2014; CBIC, 2016f).

Porém, por ser uma empresa pública com falta de investimento em hardware para todo os colaboradores, essa foi uma das formas encontradas pela organização de implantar o BIM, disponibilizando uma sala específica na qual há os softwares e hardwares necessário para se trabalhar. Além disso, também por falta de conhecimento da Empresa 2 em relação ao método, na percepção dos colaboradores, essa forma de trabalho que isola os profissionais é a ideal para evitar interrupções, melhorar a comunicação e aumentar o foco no projeto; o que, apesar de realmente acontecer, é contrário à proposta do BIM e inviável na maioria das empresas.

Os projetos-pilotos de adequação de estações existentes foram o escopo de licitações que estavam em contratação, mas foram paralisadas. Escolheram também esse projeto por não ser tão complexo, possuir uma grande variedade de disciplinas possíveis e representarem os projetos da Empresa 2, o que é o mais indicado para o projeto-piloto, conforme CBIC (2016b). Apesar da complexidade não ser alta, pelos profissionais não atuarem com o desenvolvimento de projetos, em alguns momentos eles precisaram do auxílio dos profissionais mais experientes da empresa, o que foi dificultado por estarem em um ambiente apartado da 
organização e por esses outros colaboradores não saberem utilizar as ferramentas BIM para consultarem à distância, o que estava sendo questionado, outro ponto negativo da Sala BIM.

Como eram projetos de adequação das dependências já existentes, empregaram a tecnologia do laser scanning para o levantamento da construção existente. Porém, não previram que também seria necessário se obter informações sobre as instalações elétricas e hidráulicas, porque por falta de conhecimento e falta de orientação da consultoria não houve um período de planejamento antes do início do projeto-piloto, o que vai contra a necessidade de planejamento e gestão do processo indicada por Cândido e Abreu (2002), Silva e Gil (2013), Eastman et al. (2014), CBIC (2016b), PMI (2013), MDIC (2018c) e CBIC (2016a). Muitos dos esforços da Empresa 2 eram focados nas orientações da consultoria e os profissionais da empresa não buscaram outras fontes de conhecimento sobre o BIM para poderem criticar ativamente o que estava sendo proposto.

A estratégia de composição da equipe dos projetos a partir da escolha de profissionais de diversas áreas da empresa trouxe bons resultados em diversos aspectos, como para evitar a grande redução da força de trabalho de uma determinada área; treinar profissionais de diversos setores para serem os agentes de mudança posteriormente dentro das organizações e conseguirem reunir colaboradores com o know-how necessário nas disciplinas e nas ferramentas. Por outro lado, esse momento foi um dos mais impactantes no quesito de resistência à mudança, principalmente dos chefes de departamentos dos quais os colaboradores estavam sendo escolhidos, por falta de conhecimento sobre o BIM e sobre a importância do projeto para a empresa. A substituição de alguns dos próprios colaboradores escolhidos para participarem do projeto-piloto demonstra que a rejeição à mudança em relação ao desconhecido está presente em todos os níveis hierárquicos da organização. Isso ocorreu pela falta de preparação dos profissionais exposta por Eastman et al. (2014), não havendo um período para a transição intelectual relacionada aos impactos no processo de trabalho existentes.

Além disso, os profissionais que atuaram no projeto-piloto não tiveram a oportunidade de se dedicarem exclusivamente por falta de entendimento da Empresa 2 em relação à importância e às necessidades do processo de adoção do 
BIM. Apesar da falta de gestão do projeto e a falta de planejamento prévio ficarem em evidência no projeto-piloto, é possível identificar que, aparentemente, a desorganização dos processos é algo comum à empresa e não especificamente à implantação do BIM.

Outra evidência da falta de planejamento é a ausência de atualização dos projetos de adaptação por três anos que estavam nos arquivos da empresa. Ademais, a apresentação do modelo praticamente todo resolvido para as demais equipes foi outro ponto da deficiência do planejamento do processo, porque essa experiência gerou retrabalho para a equipe de modelagem, atrito entre os colaboradores e rejeição dos profissionais à mudança, a partir da visão ruim que tiveram do BIM nessa primeira experiência.

Durante a experiência do projeto-piloto, nem tudo foi desenvolvido ou ensinado para a equipe, sendo que as famílias dos objetos estavam sendo desenvolvidas pela consultoria, o que diminui a capacidade de aprendizado com a experiência do projeto-piloto. Decidiu-se adotar nesse projeto-piloto os usos do 3D, 4D e do 5D, sendo a modelagem paramétrica da estação; as fases do existente, do que deveria ser demolido e, posteriormente, as novas construções, e a extração de quantitativos para compra.

Para o 5D foi utilizado também o Dynamo, porém, como a equipe da Empresa 2 não recebeu o treinamento necessário nessa ferramenta, novamente a consultoria entregou essa parte pronta para a empresa, o que prejudica o aprendizado e os próximos projetos. Além disso, a empresa não teve tempo de verificar se essa extração de quantitativos havia sido mais ou menos assertiva do que as realizadas da maneira convencional, o que não permite medir a eficiência desse método.

Em compensação, esse primeiro projeto-piloto foi claramente um laboratório de experiências para a Empresa 2, na qual eles aprenderam com muitas das dificuldades encontradas. Para o segundo projeto-piloto, a empresa melhorou a sua atuação com o método, sendo que a clara necessidade da definição de um coordenador para o projeto foi atendida, conforme aponta CBIC (2016b); a falta de foco dos profissionais que fez com que o projeto se estendesse por um ano devido à divisão do tempo deles com as outras atividades do dia a dia das suas áreas de origem foi resolvida; a modelagem em nível de detalhamento baixo, inicialmente, e o envolvimento das áreas impactadas durante o processo para evitar um retrabalho posteriormente foi prevista; e o tempo de planejamento antes de iniciar o projeto 
para a identificação das necessidades daquele projeto, atualizações de estudos necessárias e levantamentos in loco.

A verificação de incompatibilidades e a melhor visualização do projeto nas reuniões, garantindo a compreensão de todos e a rapidez na solução dos problemas, que foram identificados pelos profissionais é relatado como um dos benefícios do BIM na bibliografia de CBIC (2016a), Azhar (2011), Eastman et al. (2014) e CBIC (2016f). Outro benefício relevante para a Empresa 2 com o BIM no projeto-piloto foi a diminuição de retrabalho, a melhoria na comunicação, a redução do tempo de projeto pela modelagem simultânea, a facilidade na verificação de incompatibilidades, o projeto com maior qualidade, identificados por Abdelmohsen (2012), Mordue, Swaddle e Philp (2016), Azhar (2011), CBIC (2016a), McGraw Hill Construction (2014) e CBIC (2016f).

Apesar dos obstáculos encontrados no caminho e das muitas lições aprendidas, foi possível mostrar valor nos projetos que estavam sendo desenvolvidos e a importância da implantação do BIM, que teve como resultado a criação de um departamento que cuida também desse processo. A empresa conseguiu desenvolver materiais relevantes sobre o processo durante os projetospilotos, como o BIM Mandate, essencial para definir como a Empresa 2 trabalha com o método e espera receber os seus modelos; o BIM Execution Plan, que organiza o fluxo de trabalho e padroniza as entregas das empresas e a biblioteca de componentes específicos da Empresa 2, para fornecer a projetista para entregar o produto final com esses elementos.

A própria arquiteta entrevistada da empresa realizou, após o projeto-piloto, um estudo comparativo entre o modo convencional de projeto e o realizado com BIM. Outros pontos relevantes de mudança dentro da Empresa 2 foram:

a) Projetos convencionais que possuíam tempo para o planejamento e os projetos em BIM, o que não teve explicação e nem justificativa pela alta hierarquia;

b) Os projetos convencionais são divididos em funcional, básico e executivo, porém com o BIM, aparentemente, essas definições se perdem e o projeto é definido por nível de detalhamento (AIA, 2008);

C) As tarefas que antes eram sequenciais, com o novo método são possíveis serem feitas simultaneamente (MORDUE; SWADDLE; PHILP, 2016; EASTMAN et al., 2014; CBIC, 2016F); 
d) Antes os projetos focavam muito na documentação gráfica, porém como as ferramentas BIM já simplificam muito essa etapa, agora os profissionais perceberam que conseguem focar mais na qualidade do projeto;

e) Maior interação entre as áreas envolvidas no projeto, sendo as áreas de obras, operação e manutenção as quais receberão 0 modelo. Posteriormente são envolvidas nas tomadas de decisão do modelo BIM.

Entre os dois primeiros projetos-pilotos houve muitas lições aprendidas, conforme o Quadro 3.

Quadro 3 - Comparação entre os dois primeiros projetos-pilotos

\begin{tabular}{|c|c|c|c|}
\hline & & PROJETO PILOTO 1 & PROJETO PILOTO 2 \\
\hline \multirow{2}{*}{$\begin{array}{l}\text { LEVANTAMENTO } \\
\text { INICIAL }\end{array}$} & ESTRUTURA & \multicolumn{2}{|c|}{ LASER SCANNING PREVISTO ANTES DE INICIAR O PROJETO } \\
\hline & $\begin{array}{l}\text { ELÉTRICA, } \\
\text { HIDRÁULICA E } \\
\text { SISTEMAS } \\
\end{array}$ & PESQUISA EM CAMPO DURANTE A MODELAGEM & PESQUISA EM CAMPO ANTES DA MODELAGEM \\
\hline \multicolumn{2}{|c|}{ COMPOSIÇÃO DA EQUIPE } & $\begin{array}{c}\text { ARQUITETOS/ENGENHEIROS/TÉCNICOS DE } \\
\text { DIFERENTES ÁREAS }\end{array}$ & $\begin{array}{l}\text { NOVOS INTEGRANTES PARA DIVERSIFICAR O } \\
\text { APRENDIZADO }\end{array}$ \\
\hline \multicolumn{2}{|c|}{ COORDENAÇÃO DO PROJETO } & $\begin{array}{l}\text { NÃO FOI DEFINIDO UM PROFISSIONAL } \\
\text { INICIALMENTE, APENAS NO FINAL }\end{array}$ & $\begin{array}{l}\text { NECESSIDADE IDENTIFICADA E GESTÃO } \\
\text { FORMALIZADA INICIALMENTE }\end{array}$ \\
\hline \multicolumn{2}{|c|}{ PLANEJAMENTO INICIAL } & NÃO PREVISTO PLANEJAMENTO & $\begin{array}{c}\text { PLANEJAMENTO, DESENVOLVIMENTO DE } \\
\text { CRONOGRAMA E ATUALIZAÇÃO DO ESTUDO DE } \\
\text { ATUALIZAÇÃO DAS INTERVENÇÕES }\end{array}$ \\
\hline \multicolumn{2}{|c|}{$\begin{array}{l}\text { ESPAÇO FÍSICO DE } \\
\text { DESENVOLVIMENTO }\end{array}$} & \multicolumn{2}{|c|}{ SALA BIM DENTRO DA EMPRESA DE CONSULTORIA } \\
\hline \multicolumn{2}{|c|}{ CONSULTORIA } & \multicolumn{2}{|c|}{ CONSTANTE DURANTE O DESENVOLVIMENTO DO PROJETO } \\
\hline \multicolumn{2}{|c|}{$\begin{array}{l}\text { REUNIÃO DE APRESENTAÇÃO PARA } \\
\text { AS OUTRAS ÁREAS DA EMPRESA }\end{array}$} & FEITA APENAS NO FINAL & PREVISTAS 3 NO CRONOGRAMA DO PROJETO \\
\hline \multicolumn{2}{|c|}{ NÍVEL DE DETALHAMENTO } & $\begin{array}{c}\text { LOD NECESSÁRIO PARA COMPATIBILIZAÇÃO } \\
\text { FINAL }\end{array}$ & $\begin{array}{l}\text { INICIALMENTE BAIXO E AUMENTOU APENAS SOB } \\
\text { APROVAÇÃO DAS DEMAIS ÁREAS }\end{array}$ \\
\hline \multicolumn{2}{|c|}{ SEQUÊNCIA DE TRABALHO } & $\begin{array}{l}\text { MODELAGEM DA SITUAÇÃO ATUAL, DAS } \\
\text { INTERVENÇÕES E DA ATUALIZAÇÃO DAS } \\
\text { INTERVENÇÕES (ATUALIZAÇÃO DA NORMA) }\end{array}$ & $\begin{array}{l}\text { MODELAGEM DA SITUAÇÃO ATUAL E DAS } \\
\text { INTERVENÇÕES JÁ ATUALIZADAS COM A NORMA } \\
\text { ATUAL, SEM RETRABALHO }\end{array}$ \\
\hline \multicolumn{2}{|c|}{$\begin{array}{l}\text { RELACIONAMENTO COM AS } \\
\text { DEMAIS ÁREAS }\end{array}$} & GEROU ATRITO COM AS DEMAIS ÁREAS & $\begin{array}{l}\text { GEROU MENOS ATRITO E O TRABALHO FLUIU } \\
\text { MELHOR }\end{array}$ \\
\hline \multicolumn{2}{|c|}{ TEMPO } & $\begin{array}{l}1 \text { ANO - MAIOR DO QUE OS PROJETOS } \\
\text { CONVENCIONAIS }\end{array}$ & $\begin{array}{c}3 \text { A } 4 \text { MESES, SEMELHANTE AOS PROJETOS } \\
\text { CONVENCIONAIS }\end{array}$ \\
\hline
\end{tabular}

Fonte: A autora (2019)

A empresa seguiu com mais alguns projetos-pilotos, sempre aprendendo de uma experiência para outra, mas sem buscar maiores informações sobre o melhor caminho para se trabalhar com o BIM, por esse motivo seguiram utilizando a Sala BIM. Os projetos desenvolvidos virarão obras, porém por serem uma empresa pública não se podendo restringir o público das licitações, então não previram nenhuma obrigatoriedade da empresa contratada utilizar o processo BIM durante a obra. Esse posicionamento dificulta muito a adoção do BIM como processo 
corporativo, tendo em vista que eles estão dispostos a aceitarem projetos e obras com ou sem o método BIM.

\subsection{Empresa 3}

A partir do estudo de caso nesta empresa foi possível identificar que o processo de adoção do BIM se iniciou em 2011, mas o primeiro projeto-piloto só foi colocado em prática em 2014, quando também contrataram profissionais experientes do mercado e uma consultoria para auxiliar nesse processo. Mais uma vez a adoção do BIM se mostrou morosa dentro da empresa, mesmo nesse caso sendo uma organização privada. Muito disso é consequência da falta de conhecimento sobre o método.

Durante esse período ainda foram realizados treinamentos nas ferramentas para a equipe interna, conforme Eastman et al. (2014), Manzione (2013) e Succar e Kassem (2015) indicam como essencial para o processo de adoção. Porém também não houve planejamento para a adoção do BIM na Empresa 3, o que ocasionou uma série de contratações e alongamento do processo de adoção na organização. A definição da área como Construção Virtual a partir do uso de métodos e softwares é relacionada ao BIM na bibliografia por CBIC (2016a), que relata a capacidade de desenvolver digitalmente todo o empreendimento e as suas fases de constituição.

Com a contratação do profissional responsável para essa área em 2014, o projeto-piloto e a adoção do BIM na empresa poderiam ter sido melhor estruturado, porém a ansiedade da alta hierarquia para implantar e ver os resultados do método se sobrepuseram a fazer a implantação com qualidade. Apesar dessa necessidade de inovações ser evidenciada por Melhado e Oliveira (2006), Cardoso (2005) e Catelani e Santos (2016), é necessário entender que o BIM possui uma curva de aprendizado que precisa ser respeitada, portanto esperar resultados em curto prazo pode gerar frustração nos colaboradores por falta de conhecimento.

A falta dessa preparação fez com que a empresa não buscasse maiores informações sobre o método e seguisse estritamente as indicações da consultoria. Por esse motivo, a fase importante de escolha do projeto-piloto foi contrária à orientação dos autores CBIC (2016b), porque a complexidade da obra era muito elevada. Antes do projeto-piloto, tiveram algumas experiências com o BIM 4D em 
refinarias por uma demanda da contratante, porém como contrataram alguém específico para fazer essa atividade, perderam a oportunidade de treinar internamente e utilizar esses projetos como piloto da empresa.

Como a escolha do projeto-piloto não foi feita corretamente, assim como não houve planejamento para a implantação, só se deram conta da quantidade de obstáculos para a adoção do BIM nessa obra quando iniciaram. Os projetos de todas as estações que estavam em 2D e desatualizados, problema previsto por Eastman et al. (2014); a falta de previsão de um tempo para a atualização deles e a modelagem 3D; a necessidade de realizar a compatibilização desses projetos; 0 desenvolvimento da obra em paralelo com a modelagem; e a falta de apoio dos engenheiros da obra para realizarem o 4D que gerou a necessidade da contratação de um profissional do mercado; foram alguns dos problemas pelos quais a empresa passou nesse projeto-piloto. Por esse motivo, a eficiência do BIM não pôde ser medida, visto que até em uma obra sem BIM todas essas questões teriam impactado consideravelmente o índice de retrabalho e o prazo da obra.

Além disso, o prazo curtíssimo, os projetos em 2D e a quantidade de revisões, agravou o desenvolvimento com o BIM, impedindo a verificação dos benefícios do método, a confiabilidade no modelo para a extração de quantitativo e inviabilizou a sua implantação na obra, principalmente porque deixou de utilizar o BIM antes da sua conclusão, sendo esse um dos obstáculos de implantação do BIM identificados por Smith (2013). A falta de compreensão do BIM na época, a rejeição à mudança e a falta de valorização do processo de adoção do método impactou negativamente a experiencia do projeto-piloto.

Os profissionais da obra rejeitaram a aprendizagem tanto do processo BIM quanto dos novos softwares, visto que estavam com outras preocupações naquele momento e sem tempo para aprenderem. Isso demonstra a grande rejeição à mudança que é constantemente encontrada nas empresas e no processo de adoção do BIM (SILVA; GIL, 2013) (CÂNDIDO; ABREU, 2002). Uma das formas que encontraram de contrapor isso foi mostrando a importância dessa revolução tecnológica dentro da empresa e o apoio do presidente nessas demandas internas.

Os usos que o BIM teria dentro da empresa foram sendo identificados ao longo do caminho, durante a sua utilização desorganizada pelos membros da equipe. Apenas cinco anos após o início da adoção do BIM que esses usos foram definidos e colocados no papel em um Plano BIM da empresa. Novamente, nesse 
momento, fica clara a falta de planejamento da adoção do método, a falta de clareza dos passos a serem feitos e o que fazer em cada etapa.

Além do Plano BIM, foram desenhados os processos de trabalho com o 3D, - 4D e o 5D, criaram um plano de comunicação e gestão, avaliação de aplicabilidade, criaram a estrutura do BEP, definiram os usos BIM e descobriram muitos conteúdos sobre o método, o que permitiu apresentar para a empresa um plano estruturado de atuação da área. Iniciou-se um plano de treinamentos para a equipe de obras, que só foi possível quando tiveram o total apoio da alta hierarquia e, consequentemente, o investimento para tal ação. Encontraram, também, nesse momento, resistência à mudança dos profissionais em treinamento. É muito comum os profissionais questionarem a necessidade da alteração da forma de trabalho. No olhar restrito deles já era suficiente o resultado convencional.

O BIM pode ser feito em cada fase do macrofluxo de um empreendimento, podendo começar na empresa de projeto e ser repassada para a construtora ou a construtora pode repassar para a operação e manutenção, enfim, o modelo pode ser gerado a qualquer momento. Apesar disso, o fluxo ideal do BIM é de que se inicie a modelagem na fase de projeto conceitual e que ele seja atualizado até o as built após a obra. Quando houver intervenções nas fases de operação e manutenção, que essas sejam sempre atualizadas no modelo, conforme o ciclo de vida de um empreendimento demonstrado na Figura 8.

Contudo, para que isso seja possível, as empresas do mercado de cada uma das fases existentes precisam também estar preparadas para desenvolverem e receberem esses modelos, porém, isso não ocorre hoje em dia e está em fomento pela CBIC (2016b). Essa é uma das dificuldades que a Empresa 3 encontrou, bem como a falta de empresas de projeto que trabalhem em BIM, o que dificulta o trabalho da construtora, pois os projetos que chegam em 2D precisam ser totalmente modelados (EASTMAN et al., 2014).

Até o momento, a Empresa 3 identificou que o BIM melhora a qualidade dos projetos, a visualização dos mesmos, a comunicação com o cliente, o planejamento da obra, o acompanhamento da produção, a verificação de incompatibilidades, a identificação de dificuldades de construtibilidade, a diminuição de retrabalhos, a redução do tempo e melhor desenvolvimento de propostas comerciais. Tudo isso é evidenciado na bibliografia de Abdelmohsen (2012), Mordue, Swaddle e Philp (2016), Azhar (2011), CBIC (2016a), McGraw Hill Construction (2014) e CBIC 
(2016f). Porém, ainda tiveram muitas lições aprendidas, dentre elas a de que a modelagem simultânea com a obra não é eficiente, sendo os benefícios e os recursos do BIM minimamente aproveitados; e que apesar do esforço da área ou dos profissionais, a real utilização pelos demais setores só acontece quando existe uma exigência interna pela alta hierarquia.

Apesar do tempo de adoção do BIM por oito anos, em 2018 a empresa desenvolveu uma iniciativa revolucionária na construção do mercado brasileiro, disponibilizando o acesso ao modelo BIM in loco em qualquer localidade da obra. Isso agiliza o trabalho, a identificação de inconsistências na obra, o acionamento dos projetistas em caso de necessidade de revisão e garante a atualização do cronograma da obra praticamente online. Essa grande mudança só foi possível ser feita devido ao investimento realizado pela empresa e pela atuação constante do presidente da Empresa 3 nesse tema.

A partir disso é possível perceber que a precipitação da empresa ao implementar as ferramentas, treinar e utilizar tudo ao mesmo tempo, sem planejar os passos para a adoção, inicialmente, e os períodos necessário para o amadurecimento da equipe conforme relatado por Succar e Kassem (2015), e CBIC (2016b), fizeram com que a adoção do BIM nessa empresa se estendesse por anos, gerando projetos-pilotos falhos e frustrações.

Apesar da falta de apoio para a exigência da utilização que se traduziu na necessidade de gerar resultados em pouco tempo, ignorando o tempo necessário de entendimento e planejamento da implantação, todas essas experiências serviram de aprendizado. Ao longo do tempo, Empresa 3 desenvolveram o seu Plano BIM e se iniciou a adoção corporativa do método na companhia, ficando claro o amadurecimento dos estágios da adoção do BIM na organização, relatado por Succar e Kassem (2015) como a última fase. Essa experiência deixa evidente a necessidade de criar um Plano de Adoção do BIM antes de começar qualquer projeto ou iniciativa dentro das empresas.

\subsection{Empresa 4}

O processo de adoção do BIM da Empresa 4, assim como no da 3, começou a partir de uma busca pela melhoria de processos nas obras complexas e pela excelência operacional. O BIM surgiu também, nesse caso, como uma solução para 
os problemas que a organização vinha enfrentando com o retrabalho, os atrasos de cronograma e desperdícios, sendo muitos deles intrínsecos à indústria $\mathrm{AEC}$, conforme evidenciam Eastman et al., (2014) e Ferreira e Zancul (2016). Nessa empresa, algumas ferramentas BIM foram adotadas como tentativas isoladas, porém sem treinamento ou conhecimento prévio do processo. O processo real de adoção corporativa na Empresa 4 iniciou com o diretor de engenharia, que decidiu que o método seria implantado, a princípio, nas propostas e, posteriormente, nas obras da empresa.

Por orientação do diretor, em 2017, a área de propostas iniciou a utilização das ferramentas da Autodesk por conta própria, sem 0 treinamento ou 0 conhecimento prévio, começando o seu primeiro projeto-piloto na área de propostas, sem estruturação, sendo apenas uma experiência para aprender a usar as ferramentas.

Como a grande maioria dos profissionais do setor nunca havia utilizado ferramentas BIM e nenhum deles entendia o significado do método, a tentativa foi frustrada, sem grandes resultados, porém foi uma boa forma de demonstrar para a alta hierarquia o tamanho do projeto que seria a implantação do BIM, muito mais do que apenas utilizar softwares, sem investimentos em planejamento, treinamento e conhecimento, conforme evidenciado por Succar e Kassem (2016), Eastman et al. (2014), Mordue, Swaddle e Philp (2016), Abdelmohsen (2012) e CBIC (2016a). Além disso, mesmo sem o conhecimento prévio necessário, já almejaram com esse piloto o 3D, o 4D e o 5D, sem passar pela maturidade necessária do processo.

Por falta de planejamento e estruturação do processo, a iniciativa não teve muitos resultados e pouco foi o que os colaboradores aprenderam. Porém, foi possível perceber a magnitude da implantação de um novo método e que isso traria uma completa mudança no processo de trabalho da empresa, portanto o diretor levou a proposta para a alta hierarquia da organização. Entenderam então que o processo de adoção do BIM deveria fazer parte do planejamento estratégico da companhia, a ser estruturado um plano de adoção do método na empresa, o que seria uma implantação conduzida em até 3 anos.

Como não optaram pela contratação de uma consultoria e nem pela contratação de profissionais experientes do mercado no método para a implantação do BIM, como as outras empresas dos estudos de caso, criaram uma equipe interna para desenvolver a adoção do método na Empresa 4. Essa equipe ficou 
responsável por trazer todo o conhecimento sobre BIM da bibliografia, do mercado e de todas as fontes possíveis de conhecimento para a empresa; para então entenderem como deveria ser desenhado o plano de adoção do BIM. Essa etapa foi muito importante para a empresa, porque não é possível implantar qualquer inovação sem antes compreendê-la.

A equipe responsável teve que se dividir entre suas atividades diárias das suas áreas de origem e as de conhecimento e entendimento sobre o BIM, porque não foi exigido pela alta hierarquia que esses profissionais ficassem alocados em tempo integral nesse projeto. Novamente aqui se vê a falta de compreensão sobre o tamanho do trabalho necessário a ser desenvolvido para a implantação efetiva do BIM, o que seguiu um caminho semelhante da Empresa 2 e teve o mesmo resultado de ineficiência pela falta de exclusividade.

Os colaboradores envolvidos dividiram os três anos que teriam para a implantação do BIM e separaram o primeiro ano apenas para estudar sobre o método, dada a falta de conhecimento e a preparação prévia nas suas formações. Fizeram um estudo bastante completo sobre o BIM e sobre as práticas do mercado para então estruturar o processo dentro da empresa, não só com organizações do mesmo ramo de atuação, mas também com fornecedores de projetos, de materiais, clientes e empresas de outros setores, o que fez esse estudo ser bastante rico.

Tentaram dividir o primeiro ano em três momentos, porém, por uma deficiência de conhecimento da equipe designada, a primeira etapa de entendimento e aderência do conteúdo e do significado do BIM se estendeu por mais tempo do que o esperado. Apesar da equipe ser composta por nove pessoas, todas elas tiveram que estudar, ler livros, artigos, assistirem webinars e iniciaram cursos; ao mesmo tempo que realizavam o benchmarking com os diversos profissionais do mercado; e também estruturavam eventos a cada três semanas dentro da organização para compartilharem o conhecimento que estavam coletando com os demais colaboradores, para iniciarem o fomento do BIM dentro da Empresa 4. Essas rodadas de constantes palestras para os profissionais da organização foram de grande importância para garantirem o entendimento e a aderência das informações, seguindo a mesma curva de aprendizado utilizada pela Empresa 1. A abordagem de coleta de informações, de aprendizado e de treinamento interno foi muito bem estruturada e planejada dentro da empresa, o que trouxe resultados positivos para a organização. 
Esse atraso fez com que a segunda etapa de investigação e diagnóstico atrasasse para começar. Além disso, essa fase não foi bem estruturada, sendo que a princípio reservaram três meses para realizarem o diagnóstico existente dentro da empresa e o que deveria ser substituído para suportar o uso do BIM internamente. Para isso, realizaram uma investigação dos sistemas existentes para entenderem os problemas já presentes hoje e, agora com o conhecimento do BIM, quais as necessidades que eles teriam com o emprego do método e o que deveria ser desenvolvido para garantir o compartilhamento de informações entre os softwares e entre os colaboradores, necessidades evidenciadas por Manzione (2013), MDIC (2018c), CBIC (2016b), Ruschel (2014), Abaurre et al. (2011), Abaurre, Manzione e Melhado (2011), Amorim (2015). Muitos os problemas levantados referentes aos processos sistêmicos são aqueles que impactam também o método de trabalho sem o BIM, mas que, por uma certa negligência, as empresas acabam não melhorando por falta de recursos financeiros ou pela percepção da importância.

Decidiram, na organização, também realizar, nessa etapa, pilotos em obras, tanto para testar o BIM e conseguir enxergar as necessidades de melhoria interna de processos, sistemas e comunicação que não estavam conseguindo mapear, quanto para atender a ansiedade da alta hierarquia por resultados, conforme Eastman et al. (2014) indica ser uma etapa importante da adoção do BIM. Nesses três meses não conseguiram extrair muitos resultados devido ao curto espaço de tempo e por ainda não estarem próximos de terem resultados para serem analisados. Nessa experiência evidenciaram o fato da construtora estar no meio do ciclo de vida do empreendimento, conforme se pode verificar na Figura 8.

Sendo assim, se a concepção do projeto e o desenvolvimento do básico e do executivo não forem desenvolvidos por fornecedores que utilizaram processos e ferramentas BIM, o trabalho inicial das construtoras será enorme, visto que eles terão que fazer o trabalho das projetistas antes de iniciarem a obra por uma deficiência evidente na indústria AEC (EASTMAN et al., 2014). Assim como a Empresa 3, a 4 enfrenta o mesmo problema com o uso do BIM, se o projeto não vem modelado e pronto para ser utilizado na obra, as construtoras precisam de um tempo inicial não existente hoje no cronograma delas, para realizarem a modelagem dos projetos em $2 \mathrm{D}$ recebidos pelos fornecedores.

Pensando nisso, a empresa escolheu para os pilotos as obras nas quais os modelos em 3D já vieram prontos do fornecedor, do contrário teriam que 
desenvolvê-lo internamente ou contratarem uma empresa para fazê-lo, porém, isso ainda não foi pensado e nem definido como eles contornarão esse problema. A Empresa 4 destaca que esse problema seria sanado se a demanda viesse dos clientes, porque como eles fazem a contratação tanto do projeto quanto da construção, se eles exigissem que todo o projeto e construção fosse em BIM, as empresas se disponibilizariam para aprenderem e entregarem o que está sendo solicitado, para ganhar mercado.

O primeiro projeto-piloto que fizeram em uma obra, tendo recebido o modelo 3D, não veio formatado da maneira necessária para a construtora conseguir utilizálo para o 4D e o 5D, sendo que mesmo nesses casos eles ainda tiveram um trabalho inicial de ajuste do modelo. Esse é um ponto importante no processo de adoção do BIM destacado por Eastman et al. (2014), que evidencia a importância em definir previamente, junto com o fornecedor, quais são as informações e os usos que o modelo deverá conter, para que seja garantido que os dados cruciais e a manipulação do modelo seja eficiente. Então, enfrentaram essa dificuldade inicial para conseguirem iniciar os testes, a partir disso realizaram o 4D para obra e começaram a treinar a equipe daquela obra específica.

Esses projetos-pilotos serão claramente sempre um trabalho bastante moroso de ajuste do modelo ou desenvolvimento do modelo que não vem pronto, treinamento de toda a equipe de cada uma das obras, suporte constante para tirar dúvida e resolução de problemas. Isso persistirá enquanto a adoção do BIM não for corretamente planejada, estruturada e executada (CBIC, 2016b). As lições aprendidas pela Empresa 4 são muitas, dentre elas puderam entender as deficiências do modelo 3D e quais as necessidades que eles têm do recebível para então poderem solicitar aos seus fornecedores, nos casos em que forem responsáveis pela contratação do projeto, ou poderem indicar a qualidade do modelo ao recebê-lo do cliente. Para isso, foi levantada a necessidade de automatizar o processo de checagem do modelo, para a padronização e terem a percepção de quando é ou não possível utilizá-lo sem ajustes.

$\mathrm{Na}$ área de propostas, os projetos-pilotos já substituíram uma etapa existente no processo deles, havendo a necessidade de transformar os PDFs em projetos 2D, porém agora transformam direto em um modelo com nível de detalhamento baixo. Uma forma de melhorar o processo nessa etapa seria já exigir o modelo do cliente, quando houver, para que o tempo da proposta seja menor, o valor seja mais 
assertivo e a qualidade seja maior. Com isso também desenvolveram o BEP, material importante para os casos em que contratarem o projeto.

Durante as etapas 1 e 2, a Empresa 4 conseguiu tirar diversas conclusões e começar a desenhar o Roadmap, ou seja, o caminho a ser trilhado pela empresa para adotar efetivamente o método BIM dentro dos seus processos e operações, conforme indicada a necessidade por CBIC (2016b). Nesse documento foram definidas quais as melhorias sistêmicas dentro da empresa que deveriam acontecer, os processos que deveriam ser redesenhados, o plano de treinamento, o investimento, dentre outras informações relevantes que não puderam ser analisadas devido à recusa da empresa em divulgar o material.

Mesmo sem o Roadmap aprovado pela alta hierarquia e ainda em desenvolvimento, a empresa decidiu aumentar a quantidade de pilotos tanto nas obras quanto nas propostas. Isso representa um eminente risco de frustração da organização e dos seus colaboradores com o método BIM, pela falta de estruturação do processo, treinamento dos envolvidos e investimentos.

A rejeição à mudança nessa empresa também existiu, mas foi menor do que nas outras, devido a um processo de transformação cultural que vem acontecendo na Empresa 4 há mais de quatro anos devido à implantação de inovações constantes. A criação de áreas focadas em excelência operacional, organizacional e de tecnologia demonstra o crescimento e o amadurecimento da cultura da empresa em direção ao aperfeiçoamento constante dos seus processos.

Por esse motivo, a colaboração dos diferentes profissionais envolvidos neste projeto foi espontânea e interessada. Isso tende a ser cada vez mais comum e, conforme o BIM, tende a se popularizar no mercado nacional e internacional, tornando-se cada vez mais familiares para os profissionais do mercado. $\mathrm{O}$ início do compartilhamento do conhecimento com os demais colaboradores da empresa, trouxe grandes benefícios para a empresa e a rejeição à mudança começou a ser cada vez menor entre os colaboradores. 


\section{ANÁLISE FINAL}

Nessa seção é feita a análise entre os estudos de caso e a revisão bibliográfica. O quadro resumo desse diagnostico se encontra no Quadro 4. 
Quadro 4 - Desafios para a adoção e o uso do BIM

\begin{tabular}{|c|c|c|c|c|c|}
\hline & EMPRESA I & EMPRESA $7^{2}$ & EMPRESA 2 & EMPRESA 3 & EMPRESA 4 \\
\hline MOTIVAÇĀo & $\begin{array}{l}\text { Proatividade dos colaboradores de identificar as } \\
\text { melhorias e as inovaçooses do mercado; }\end{array}$ & $\begin{array}{l}\text { Obrigatoriedade pelo Plano de Negócios } \\
\text { do governo; }\end{array}$ & $\begin{array}{l}\text { Diretoria almejando a diminuiẹcá de retrabalho, } \\
\text { aditivos e perda de prazo; }\end{array}$ & $\begin{array}{l}\text { Diretoria almejando a diminuiçao de problemas existentes } \\
\text { como retrabalho, aditivos e perda de prazo; }\end{array}$ & Diretoria em busca de inovaçáa e excelência operacional; \\
\hline $\begin{array}{l}\text { ÁREA } \\
\text { RESPONSÁVEL }\end{array}$ & Projeto Básico / Gerência de Projeto Básico Civil & Organizacional / Inovaçāo BIM & $\begin{array}{l}\text { Projeto Básico / Departamento de Consistência e } \\
\text { Inovaçáo de Projetos }\end{array}$ & Suporte interno / Construçāo Virtual & Área de propostas / grupo criado \\
\hline $\begin{array}{l}\text { PLANO DE } \\
\text { ADOÇĀAO }\end{array}$ & Náo estruturado; & $\begin{array}{l}\text { Primeiro grande esforço realizado após o } \\
\text { recebimento da demanda; }\end{array}$ & $\begin{array}{l}\text { Estruturado em forma dos objetivos da área } \\
\text { responsável pela implantaçao na empresa; }\end{array}$ & $\begin{array}{l}\text { Estruturado em forma dos objetivos da área responsável } \\
\text { pela implantaçáo na empresa, após projeto piloto; }\end{array}$ & $\begin{array}{l}\text { Estruturado após o primeiro ano de estudo e investigaçáo } \\
\text { sobre a metodologia; }\end{array}$ \\
\hline $\begin{array}{l}\text { DECISĀA DE } \\
\text { IMPLANTAÇAO }\end{array}$ & $\begin{array}{l}\text { Atividades rotineiras de revisáo e validaçáo de } \\
\text { projetos; }\end{array}$ & $\begin{array}{l}\text { Estruturar o Plano Bim para implantaçāo } \\
\text { organizacional: }\end{array}$ & $\begin{array}{l}\text { Modelagem de Projetos de Adequaçăo às normas } \\
\text { de acessibilidade; }\end{array}$ & Implantar o BIM nas obras; & Implantar o BIM nas obras; \\
\hline $\begin{array}{l}\text { START NA } \\
\text { IMPLANTAÇĀO }\end{array}$ & $\begin{array}{l}\text { A alta hierarquia foi convencida do potencial } \\
\text { representado pelo BIM e decidiu investir; }\end{array}$ & $\begin{array}{l}\text { Obrigatoriedade da implantação pelo } \\
\text { novo Plano de Negócios do governo: }\end{array}$ & $\begin{array}{c}\text { Momento de renovaçáa das licenças contrataçāo } \\
\text { de uma consultoria para treinamentos; }\end{array}$ & Busca por melhorias nas obras de concreto; & $\begin{array}{l}\text { Diretor decidiu implantar a metodologia na área de propostas; } \\
\text { Plano trienal definiu que o BIM deveria ser adotado; }\end{array}$ \\
\hline \multirow{3}{*}{$\begin{array}{l}\text { FORMA } \\
\text { IMPLANTAC̄ó } \\
\text { PLANEJAMENTO } \\
\text { PARA A ADCQÇAO } \\
\text { DO BIM } \\
\text { DEDICACĀO } \\
\text { EXCLUSIVA? }\end{array}$} & Contrataçáo de um profissional do mercado; & Criaçāo de um comitê para o projeto; & Alocaçáo da equipe na Sala BIM da consultoria; & Contrataçáo de um profissional do mercado; & $\begin{array}{l}\text { Criaçáa de equipe interna para desenvolver o plano de } \\
\text { adoçao do BiM; }\end{array}$ \\
\hline & Sem planejamento; & $\begin{array}{l}\text { Previsto tempo de estruturaçá, estudo o } \\
\text { planejamento do processo: }\end{array}$ & Sem planejamento; & Sem planejamento; & $\begin{array}{l}\text { Previsto um grande tempo de estruturacáa, estudo e } \\
\text { planejamento do processo no Plano de Adoçá; }\end{array}$ \\
\hline & sim & Parcial & Parcial & sim & Parcial \\
\hline OBJetivos & $\begin{array}{l}\text { Agilizar os processos da área e aumentar a } \\
\text { qualidade dos projetos; }\end{array}$ & $\begin{array}{l}\text { Realizar todos os passos necessários, } \\
\text { para garantir o sucesso da implantaçấo: }\end{array}$ & $\begin{array}{l}\text { Entender o funcionamento do processo desde o } \\
\text { início para contratar projetos em BIM; }\end{array}$ & $\begin{array}{c}\text { Identificar as necessidades para a implantaçāo e buscar } \\
\text { apoio da alta hierarquia; }\end{array}$ & $\begin{array}{l}\text { Mapear as necessidades para a implantação do BIM na } \\
\text { empresa: }\end{array}$ \\
\hline TREINAMENTOS & Internos, realizado pelo Gerente BIM contratado. & $\begin{array}{l}\text { Ciclo de palestras - nivelamento do } \\
\text { conhecimento, pesquisa de maturidade; } \\
\text { Plano de treinamanentos em estruturaçá; }\end{array}$ & $\begin{array}{l}\text { Consultoria contratada: ferramentas 3D para a } \\
\text { equipe interna; }\end{array}$ & $\begin{array}{l}\text { Consultoria contratada: ferramentas 3D para a equipe } \\
\text { interna; }\end{array}$ & $\begin{array}{l}\text { Previstos no plano de adoçāo. } \\
\text { Atualmente a busca de conhecimento está sendo por conta } \\
\text { própria por cada profissional individualmentmente }\end{array}$ \\
\hline $\begin{array}{l}\text { BIBLIOTECA DE } \\
\text { COMPONENTES }\end{array}$ & Decidiram nāo desenvolver; & - & Desenvolvido pela consultoria; & Desenvolvido pela consultoria; & - \\
\hline $\begin{array}{l}\text { MANUAL DE } \\
\text { DIRETRIZES }\end{array}$ & $\begin{array}{c}\text { Começou a desenvolver em } 2013 \text {, logo com a } \\
\text { chegada do Gerente BiM }\end{array}$ & $\begin{array}{c}\text { Previsto para ser desenvolvido na EAP do } \\
\text { plano de adoçäo }\end{array}$ & \begin{tabular}{|c|}
$\begin{array}{l}\text { Desenvolvido a partir das experiências do projeto } \\
\text { piloto; }\end{array}$ \\
\end{tabular} & Desenvolvido a partir das experiências do projeto piloto; & $\begin{array}{l}\text { Em desenvolvimento, documento previsto para o plano de } \\
\text { adoçáo do BIM }\end{array}$ \\
\hline BEP & $\begin{array}{c}\text { Desenvolveu já para o projeto pilloto em conjunto } \\
\text { com a contratada }\end{array}$ & $\begin{array}{c}\text { Previsto para ser desenvolvido na EAP do } \\
\text { plano de adoçäo }\end{array}$ & \begin{tabular}{|c}
$\begin{array}{c}\text { Desenvolvido a partir das experiências do projeto } \\
\text { piloto; }\end{array}$ \\
\end{tabular} & Desenvolvido a partir das experiências do projeto piloto; & $\begin{array}{l}\text { Em desenvolvimento, documento previsto para o plano de } \\
\text { adoçáo do BIM }\end{array}$ \\
\hline PROJETO PILTO & $\begin{array}{l}\text { No ano seguinte da contrataçáo do Gerente BIM; } \\
\text { Primeiro projeto possivel; Média complexidade; } \\
\text { Cracacterísticas semelhantes aos projetes típicos; }\end{array}$ & $\begin{array}{l}\text { Serāo feitos conforme as fases de } \\
\text { implantaçāo em cada área; }\end{array}$ & 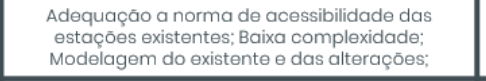 & $\begin{array}{l}\text { Complexidade elevada; Prazo impraticável; Modelagem } \\
\text { durante a obra; Treinamento durante o andamento da } \\
\text { obra; Năo finalizou a obra, náa obteve resultados }\end{array}$ & $\begin{array}{l}\text { Desenvolvidos para levantar as necessidades de melhoria nas } \\
\text { obras e sistemas para prever no plano de adoçāo; } \\
\text { Ansiedade pela alta hierarquia;; }\end{array}$ \\
\hline $\begin{array}{l}\text { BENEFICIOS } \\
\text { IDENTIFICADOS }\end{array}$ & 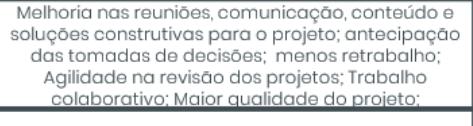 & \begin{tabular}{|l|} 
Nivelamento do conhecimento da \\
equipe sobre o BIM; Motivaçāo; Grande \\
força do projeto; Planejamento \\
minucioso;
\end{tabular} & $\begin{array}{l}\text { Melhora na identificaçáá de incompatibilidades, das } \\
\text { reunióes, da comunicaçáo e da qualidade; } \\
\text { Diminuiçaço do retrababalho e do tempo de projeto; }\end{array}$ & 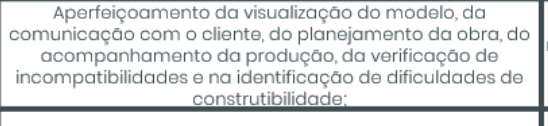 & 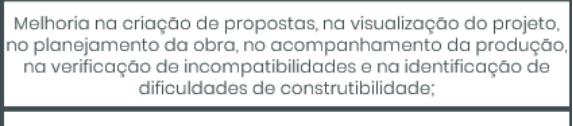 \\
\hline OBSTÁCULOS & 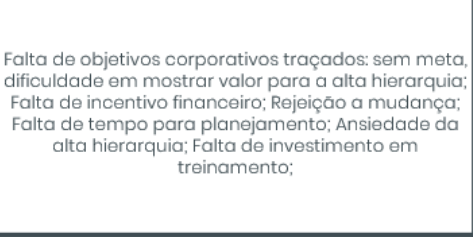 & 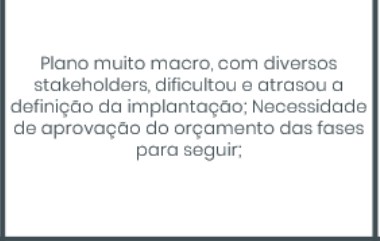 & 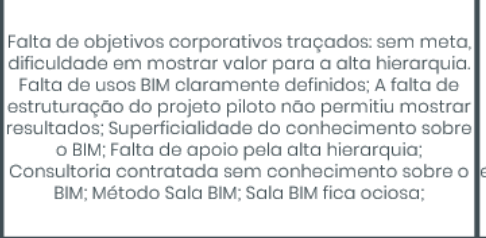 & 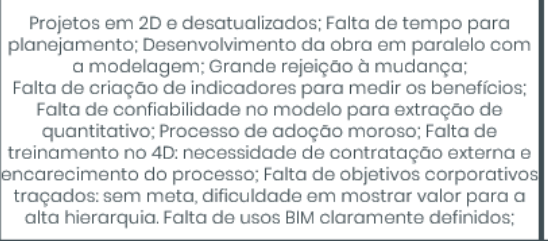 & 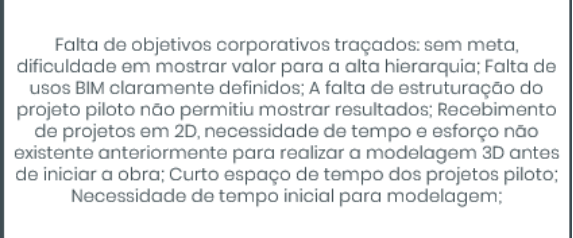 \\
\hline CONCLUSOEES & $\begin{array}{l}\text { Estruturaçāo do Plano BIM posterior aos projetos } \\
\text { piloto; Falta de planejamento do plano de } \\
\text { treinamento, porém efetivo para as necessidades } \\
\text { da área; Falta de planejamento e controle pré- } \\
\text { existentes na empresa; }\end{array}$ & 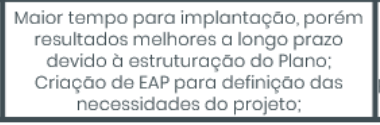 & $\begin{array}{l}\text { Falta de Estruturaçáo do Plano BIIM; Falta de } \\
\text { planejamento do plano de treinamento; Falta de } \\
\text { planejamento e controle pró-existentes na empresa }\end{array}$ & $\begin{array}{l}\text { Falta de Estruturaçáo do Plano BIM: } \\
\text { Falta de planejamento do plano de treinamento; }\end{array}$ & $\begin{array}{l}\text { Estruturaçáa do Plano BIM posterior aos projetos piloto; } \\
\text { Falta de planejamento do plano de treinamento; }\end{array}$ \\
\hline
\end{tabular}

Fonte: A autora (2019) 


\subsection{A PERCEPÇÃo DO BIM}

Contradizendo diversos autores, como Succar e Kassem (2016), Eastman et al. (2014), Mordue, Swaddle e Philp (2016), Abdelmohsen (2012), CBIC (2016a), Kamardeen (2010) e Sacks (2012, apud MANZIONE, 2013), um dos maiores mitos existentes hoje sobre o BIM na cadeia produtiva da construção civil brasileira é que o método se trata da simples aplicação de softwares, necessitando apenas da compra das licenças deles, da adequação dos hardwares e do treinamento nas ferramentas. Isso pode ser visto na experiência das empresas 2 e 3, na qual a primeira ação para fomentar a implantação do BIM internamente foi a contratação de consultoria para fornecer treinamentos nas ferramentas.

Essa percepção não foi alterada nessas duas organizações posteriormente. Na Empresa 2 decidiram criar uma Sala BIM para a utilização dessas ferramentas e durante os projetos piloto na sala da consultoria, receberam basicamente $o$ apoio técnico nos softwares ao longo de todo o projeto. Em outras palavras, não foi percebida uma grande vantagem e características do processo de trabalho com o BIM, conforme o processo colaborativo proposto pelo método e evidenciado por McGraw Hill Construction (2014), Eastman et al. (2014), CBIC (2016f), Azhar (2011), UK GOVERNMENT (2011), Kassem e Amorim (2015) e Catelani e Santos (2016). A partir dos estudos de caso fica claro que nas empresas que possuíam essa percepção, os resultados ficaram bem distantes do que as Empresas 2 e 3 buscavam e o processo de adoção do BIM se prolongou por mais tempo do que nas outras organizações para darem resultados relevantes.

Apesar da Empresa 3 no início ter encarado o processo como uma implantação tecnológica somente, começaram a perceber ao longo do caminho que - BIM seria mais do que isso ao contratar a consultoria também para instituir o processo BIM dentro da obra, portanto, começaram a reconhecer o impacto na rotina do trabalho. Após verem a rejeição à mudança gerada nos profissionais, as lições aprendidas, as rotinas criadas dentro da obra para utilizar o 3D e o 4D, entre diversos outros impactos do BIM no projeto-piloto, desenvolveram palestras de instrução interna, agora tratando o BIM como um método composto por tecnologia e processos que precisam andar juntos para funcionarem, mostrando a evolução na maturidade do processo dentro dessa empresa. 
Já a Empresa 4 investiu desde o início em estudo sobre o método, o compartilhamento do conhecimento internamente e do planejamento do processo de adoção do BIM. Por esse motivo, os resultados de aprendizado, de rejeição à mudança e à estruturação interna foram os mais rápidos dentre as quatro empresas dos estudos de caso. Como o BIM é visto, entendido e tratado no processo de implantação faz toda a diferença no tempo e nos resultados que cada organização e cada Plano BIM tem, porque, a partir disso, será definido o nível de planejamento e de controle.

A Empresa 1 foi claramente a com melhor performance e resultados obtidos no processo de implantação do BIM até o momento, em partes por ter contratado um profissional com uma grande clareza sobre o que o BIM representa e experiencia com o método. Assim, ele pôde trazer essa percepção para os processos internos da empresa e implantar as ferramentas e o processo BIM na área GPR com mais facilidade e aceitação pelos profissionais. Em seguida, essa expertise serviu também para compor a equipe de liderança do projeto corporativo de implantação do BIM (Inovação BIM), que iniciou as ações pela preparação dos profissionais pelas palestras. Entende-se que essa segunda ação da Empresa 1 será a que trará maiores benefícios dentre as cinco experiências relatadas, tendo em vista a grande estruturação e planejamento do Plano de Adoção.

\subsubsection{Motivação}

Muitas empresas decidem adotar o BIM pensando nos diversos benefícios evidenciados pelos autores CBIC (2016a), Azhar (2011), Eastman et al. (2014), CBIC (2016f), Abdelmohsen (2012), Mordue, Swaddle e Philp (2016) e McGraw Hill Construction (2014) e também por questões mais específicas, de acordo com a sua atuação e a sua necessidade.

Na primeira empresa, a iniciativa na GPR foi motivada pela proatividade dos colaboradores de identificarem as melhorias e as inovações do mercado, o que culminou na descoberta do BIM e do interesse pelo método devido aos benefícios potenciais e, assim, deram seguimento aos estudos. Similarmente, também almejando os proveitos possíveis com o emprego do método, mas com o foco na extinção dos problemas existentes como retrabalho, aditivos e perda de prazo, as Empresas 2 e 3 buscaram a implantação do BIM. 
Nas Empresas 3 e 4 os diretores das áreas de engenharia despertaram a necessidade por inovarem e descobriram o método como a solução em maior evidência na indústria AEC. O segundo processo de adoção da Empresa 1 seguiu a partir de um olhar mais maduro para a inovação e teve um peso muito maior, sendo apoiada por um Plano de Negócios do governo, por ser uma empresa pública.

\subsubsection{A adoção do BIM}

A única empresa que formalizou o seu Plano de adoção do BIM durante a duração da pesquisa foi a Empresa 1 (Inovação BIM), porém a quarta empresa estava finalizando a estruturação do seu projeto ao final do período do estudo de caso, que não pôde ser analisado por questões internas de sigilo da empresa. Antes de iniciar qualquer tipo de implementação do BIM, estruturada ou não, todas as organizações tiveram um período de curiosidade em relação ao método que se estendeu por algum tempo, não havendo responsáveis, nem treinamentos, nem projeto-piloto, apenas a intenção de aprender sobre o tema.

Nas Empresas 1 e 3, esse período de reconhecimento se estendeu entre 2011 e 2013, na 2 pesquisaram sobre o tema entre 2012 e 2014 e na 4 houve tentativas isoladas entre 2015 e 2017. Fica claro que enquanto alguém não decidiu investir realmente na implantação do método, o processo nessas empresas ficou praticamente parado sem trazer resultados. Após o período relatado, em todas as empresas houve a tomada de decisão pela alta hierarquia em relação à adoção do BIM e, em paralelo, a definição de um responsável para desenvolver e seguir com o Plano de implantação na empresa. Esse fato se repetiu em todas as instituições entrevistadas. O resumo do processo de adoção nas empresas pode ser visto no Quadro 5.

A primeira etapa para a adoção do BIM, segundo a CBIC (2016b), seria a definição de onde cada uma dessas empresas está localizada no ciclo de vida do empreendimento e, a partir disso, a determinação dos objetivos dessa implementação. Nesse cenário, as Empresas 1 e 2 são contratantes nas etapas de pré-obra e obra e atuantes no pós-obra, porém a sua implantação durante o período dos estudos de caso foi no pré-obra em projetos específicos da empresa para entender o funcionamento das ferramentas e a mudança na rotina de trabalho durante o desenvolvimento do Projeto Básico para a obra. Já as Empresas 3 e 4 atuam na fase da obra, conforme se pôde verificar na Figura 8. 
Quadro 5 - Comparação entre os projetos-pilotos

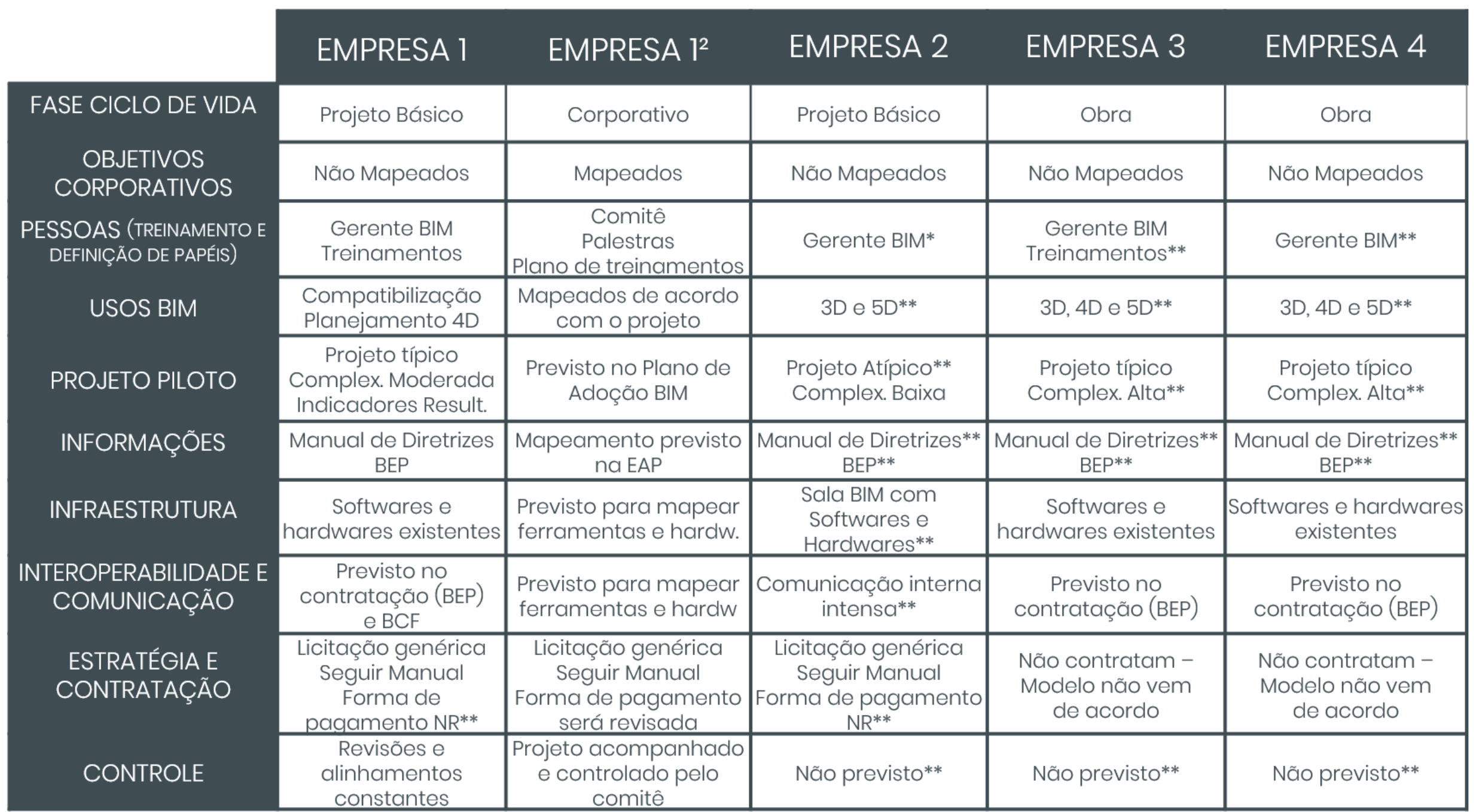

* Timing diferente do que é indicado pela bibliografia:

** Objetivo diferente do que é indicado pela bibliografia 
Essa escolha da Empresa 2 de iniciar entendendo o funcionamento do processo desde o início da modelagem foi crucial para compreender questões sobre a contratação e a medição do serviço, o que deve ser solicitado no modelo, as definições que deverão compor o contrato, a determinação de papeis e responsabilidades, a descrição dos conhecimentos e experiências desejados dos subcontratados, os usos e as informações que deverão integrar o modelo dos projetos e para a obra, o estabelecimento do processo colaborativo, como será medido o progresso, como serão feitas as revisões e qual é o nível de interoperabilidade preciso, são necessidades previstas por Eastman et al. (2014) e CBIC (2016b). Tudo isso ocorre para garantir que o produto desenvolvido seja passível de utilização pela empresa receptora sem ajustes, ao contrário do que houve na experiência da Empresa 4, que não foi a contratante do modelo, apenas o recebeu e descobriu que não seria possível utilizá-lo para os fins necessários.

A Empresa 1 (GPR) adotou o BIM para as suas atividades específicas de validação do projeto, inserindo comentários no modelo e verificando a qualidade do projeto, após uma rodada interna de treinamentos. Já as Empresas 3 e 4 apesar de terem adquirido o conhecimento das ferramentas pelos treinamentos durante os estudos de caso, decidiram ir diretamente para os projetos-pilotos nas obras (Etapa 5), na qual tentaram implantar o BIM, sem entender ainda o que precisavam receber do fornecedor para poder conduzi-las, sem desenvolver modelos para saber como manuseá-los quando fosse preciso ou tivessem que desenvolver o modelo 4D, conforme as fosse conveniente no planejamento. Essa última necessidade ocorreu na experiência da Empresa 3 e tiveram que contratar novamente uma consultora para o trabalho, o que encareceu mais uma vez o processo de implantação. Portanto, nestes casos, o planejamento do treinamento, seja em relação ao conteúdo ou ao tempo de aprendizagem, não foi suficiente para esses colaboradores compreenderem a aplicação do método.

A segunda etapa deveria ser o mapeamento dos objetivos corporativos tangíveis para esse projeto. Sem isso a empresa não possui uma direção de onde quer chegar com essa inovação e não conseguirá medir o progresso ou identificar posteriormente para reportar se a expectativa foi atingida, visto que eles não foram traçados. Ao invés de traçá-los previamente, definindo especificamente o que e quanto se espera com essa implementação, como por exemplo, a redução de $40 \%$ das incompatibilidades dos projetos, todas as organizações optaram por colocar em 
prática e identificar os benefícios atingidos depois. Apenas a Empresa 1 (Inovação BIM) previu no seu Plano de Adoção BIM o mapeamento dos objetivos corporativos tangíveis.

Os únicos benefícios almejados pelas quatro empresas foram o aumento da qualidade e a redução do tempo do projeto ou da obra, sem a definição do quanto. Um problema comum nas empresas e passível de percepção durante as entrevistas foi a deficiência da gestão e o controle dos prazos médios dos seus projetos ou das tipologias de projetos, o que provavelmente não permitiu que esses objetivos de aumento de qualidade e diminuição de prazo fossem traçados com clareza. Sem isso, ainda se dificulta a percepção de valor do projeto perante os executivos que esperam ver números ao invés de objetivos subjetivos, porque não trazem a percepção do retorno no investimento.

Definição dos participantes do projeto, designação do Gerente BIM, plano de treinamento e definição clara dos papéis e responsabilidades de cada envolvido são as questões que compõem a terceira etapa e são cruciais para garantirem o sucesso do projeto. A bibliografia de CBIC (2016a), Cândido e Abreu (2002) e Sacks (2012, apud MANZIONE, 2013) citam que as pessoas são essenciais para a implantação de uma inovação como o BIM, portanto, as empresas devem se atentar ao máximo para essa etapa do planejamento do projeto.

A Empresa 1 (Inovação BIM) teve essa percepção e foi uma das melhores a preparar os seus profissionais, por um circuito de palestras, cobrindo a maior parte dos temas referentes à plataforma BIM e prevendo na estrutura analítica do projeto o plano de treinamentos a ser aprovado no plano de investimentos pela alta hierarquia. Durante sua primeira experiência (GPR), os treinamentos foram feitos internamente pelo profissional experiente contratado, que ensinou tanto sobre a utilização das ferramentas, quanto sobre o conceito do que o BIM representa na mudança de trabalho. A Empresa 4 possui essa consciência também, principalmente após o benchmarking com o responsável da Empresa 1, que influenciou o modo da quarta empresa ver o método. Por esse motivo também realizou rodadas de palestras durante um ano dentro da organização, para motivar e instruir os colaboradores. Já os treinamentos nas Empresas 2 e 3 foram apenas mediante a contratação da consultoria que fornecia os softwares, portanto o foco foi nas ferramentas apenas. 
O Gerente BIM foi definido nas Empresas 1 (GPR), 2 e 3, sendo o responsável pela área de implantação do BIM da organização. A Empresa 1 (Inovação BIM) teve uma comissão composta por líderes do projeto e a Empresa 4 contou com uma equipe de implementação e, posteriormente, a contratação de um gerente BIM durante o andamento do processo. Então fica claro que todas as empresas perceberam a relevância em ter um profissional focado nesse tema, conforme atestado por CBIC (2016b), para se responsabilizar pela implantação, coordenação, fomento e projetos piloto dentro das organizações.

Antes de iniciarem o processo de adoção do BIM, as empresas também deveriam ter definido os usos idealizados para esse processo (CIC, 2010), porém, por falta de compreensão do método e pela falta de orientação pelas consultorias contratadas, as empresas 2, 3 e 4 definiram as dimensões macro a serem implantadas, ou seja, 3D, 4D e 5D, que diferem dos usos BIM. Na Figura 4 é possível ver que o modelo 3D seria composto por uma série de usos, como análise estrutural, energética, luminotécnica, fabricação, gerenciamento de espaços, dentre outros aspectos.

Por esse motivo, uma empresa alegar que irá adotar uma ou outra dimensão do BIM é algo vago e essa falta de clareza dificulta muito o processo de implantação. Isso vai de encontro com a falta de objetivos bem definidos, pois apenas com as metas traçadas é possível saber quais são os usos necessários no modelo para alcançar os objetivos. A Empresa 1 (GPR) já definiu logo para o primeiro piloto alguns usos mais específicos, sendo eles a compatibilização dos projetos, a análise de cenários e a extração de quantitativos. Porém, esses não estão explícitos na Figura 4, que traz os 25 usos, mas são objetivos que existem dentro de alguns dos listados.

Apesar da escolha das utilizações pela empresa, os projetos não precisam ter todos aqueles aspectos definidos. Isso deverá ser verificado de acordo com a característica de cada projeto na Figura 9. Existem cinco etapas de análise que devem ser feitas para escolher aquelas que serão empregadas, sendo o mapeamento dos possíveis usos, a definição dos responsáveis por cada um deles, se esses possuem o know how necessário para implantar com eficácia os usos pelos quais são responsáveis, os valores e os riscos de cada uso e, por fim, a tomada de decisão de quais deles serão adotados. Nenhuma das empresas realizou essas análises. A Empresa 1 (Inovação BIM) estava em processo de definição dos 
usos a serem adotados, mas tentaram seguir com o desenvolvimento de um workshop para defini-los.

Após toda essa estruturação do processo, é necessário escolher qual será o projeto-piloto para iniciar a implementação dos usos, ferramentas e aplicação do processo aprendido anteriormente. A escolha disso deverá estar alinhado com os projetos típicos desenvolvidos pela empresa e possuir complexidade moderada (CBIC, 2016b), o que foi seguido pela Empresa 1 (GPR). Já a Empresa 2 não aplicou nem o seu processo, que normalmente é apenas o de revisão e não o de desenvolvimento desses projetos, e a aplicação foi em projetos relativamente simples de adequações de estruturas pré-existentes apenas. As Empresas 3 e 4 possuem uma grande variedade de portfólio de obras a serem desenvolvidas, devido ao seu porte e à relevância no mercado, mas aparentemente os pilotos escolhidos tiveram complexidade muito elevada, o que também dificultou 0 processo de implantação. Nesse momento deverão ser definidos os objetivos gerais e específicos desse projeto, que deverão estar alinhados com aqueles objetivos da empresa, definidos na Etapa 2, e os usos para tal projeto.

Nenhuma organização se preparou para os seus projetos piloto, por esse motivo as Empresas 2, 3 e 4 não conseguiram mostrar resultados, nem aferirem se o emprego do método foi relevante para o processo. A Empresa 1 (GPR), apesar de também não ter passado por essa etapa crucial para a definição das expectativas, levantaram tanto os indicadores referentes à quantidade de interferências e comentários realizados nas revisões dos projetos, quanto à natureza deles, o que foi possível relacionar com a melhoria na qualidade do projeto, antecipação de incompatibilidades e maior agilidade no processo, tendo em vista que fizeram mais no mesmo tempo de revisão dos projetos convencionais. O seu segundo projeto, o Inovação BIM, não possuiu nenhum piloto de aplicação, mas obteve indicadores relevantes quanto ao índice de maturidade do conhecimento sobre o método dos colaboradores que participaram das palestras realizadas na empresa.

A sexta etapa é referente ao levantamento de informações necessárias para performar os usos potenciais e os fluxos de troca de informações. Essa etapa é importante inclusive para o mapeamento das necessidades que deverão compor o contrato com as subcontratadas. Foi desenvolvida por todas as empresas quando criaram seu BEP, devendo ser entendido o processo de trabalho com o BIM para 
identificar as necessidades de informações de cada etapa, quem deveria gerar a informação e quem deveria receber e quando. A clareza desse fluxo é fundamental para o funcionamento do trabalho na Plataforma BIM, sendo importante desenvolver esse mapeamento a partir do processo definido na Figura 10.

As Empresas 2, 3 e 4 estruturaram esse documento apenas após a primeira obra piloto, porque não tinham o conhecimento necessário de quais as informações seriam precisas no processo, quem deveriam ser os receptores e os autores. Como o responsável contratado pela Empresa 1 (BPR) possuía um conhecimento no assunto, esse mapeamento das informações necessárias e o desenvolvimento do BEP foi possível antes da contratação do projeto-piloto.

Apesar da Etapa 7 ser o momento de definir os softwares e hardwares necessários para o processo de implementação do BIM, todas as empresas entrevistadas decidiram e realizaram essa etapa antes de qualquer outra. A definição dos softwares foi de acordo com o que já havia contratado em pacotes pré-existentes na organização, portanto não houve escolha e nem investimento em nenhuma delas. Porém, para garantir a interoperabilidade, todas as instituições dos estudos de caso tiveram que definir os seus métodos de contratação o software a ser utilizado pelas empresas subcontratadas e a versão específica deles.

Em relação ao hardware, como as Empresas 1 e 2 são públicas, é comum que os equipamentos não sejam tão atuais e possuam o melhor desempenho. Por esse motivo a Empresa 1 precisou realizar alguns ajustes nas máquinas préexistentes. Já a Empresa 2 optou pela compra de máquinas novas para compor um ambiente de imersão que chamaram de Sala BIM. Esse foi um dos motivos pelos quais essa implantação na empresa demorou para ocorrer, tendo em vista o investimento necessário. Nesse momento ainda se deve criar ou definir a biblioteca de componentes BIM a ser utilizada por todos os envolvidos na modelagem, sendo isso feito pelas Empresas 2 e 3, mas a necessidade disso ainda não foi identificada pela Empresa 4. A Empresa 1 entende não haver a necessidade disso, apenas para componentes extremamente específicos da organização.

A etapa seguinte de interoperabilidade e comunicação, bastante relevante $\mathrm{e}$ exposta por Manzione (2013), MDIC (2018c), CBIC (2016b), Ruschel (2014), Abaurre et al. (2011), Abaurre, Manzione e Melhado (2011) e Amorim (2015) foi prevista pelas empresas ao definirem os hardwares mínimos, versões dos softwares, intercâmbio de informações e fluxo de comunicação. Apesar disso, 
apenas a Empresa 1 (GPR) teve a possibilidade de testar o correto funcionamento disso com a organização subcontratada, utilizando-se os mesmos softwares e versões para o compartilhamento do modelo. Para as revisões seguiram usando o formato aberto BCF para a comunicação de incompatibilidades e registro de alterações no modelo. Isso permitiu que a organização mantivesse um histórico de todas as alterações solicitadas, bem como as suas respostas, para poderem aferir a qualidade do modelo posteriormente.

Após todas essas definições e mapeamento das necessidades para a estruturação do Plano BIM, a penúltima etapa se refere à definição dos fatos e dos requisitos para a contratação dos serviços em BIM, sejam eles os projetos ou as obras. A empresa pode optar por realizar todos os processos internamente, contratando profissionais do mercado que tenham a expertise desejada. Porém, em algum momento, precisarão contratar algum serviço e, para isso, precisam ter definido o que e como será feita a contratação.

Em 2013, a Empresa 1 (GPR) lançou uma licitação solicitando o uso do BIM genericamente, porém, não era obrigatório por deficiência de materiais internos (Manual de diretrizes BIM, BEP, dentre outras normas) e por não saberem ainda exatamente o que ou como contratar projetos e obras em BIM. Após a contratação em 2014, conseguiram usar esse ano para finalizarem os documentos e a subcontratada concordou em adotar o processo BIM solicitado pela empresa, seguindo os usos idealizados e o Caderno BIM da organização. Após o projetopiloto, foi possível retroalimentar as necessidades durante a contratação e os requisitos necessários para serem previstos em contrato.

A Empresa 2 encontrou a mesma deficiência relativa ao que solicitar em uma contratação de Projeto BIM. Por esse motivo decidiu implantar o método na empresa, desenvolvendo os projetos para entender o processo desde o início, mesmo sendo uma organização contratante de projetos e obras. Compreendeu-se que sem entender o processo de modelagem, não saberiam o que solicitar para a contratação e isso pode ser visto no relato em que inseriram uma linha na licitação, solicitando que o projeto fosse "desenvolvido em BIM". A falta de clareza do que se espera gera frustrações tanto na contratada quanto na contratante, por isso é fundamental definir o que se espera do produto final.

As Empresas 3 e 4 não contratam o projeto, normalmente elas já os recebem prontos da contratante, portanto eles ficam muito dependentes do que a contratante 
solicitou previamente. Como pode ser visto nas experiências dessas organizações, isso dificulta muito o trabalho das construtoras. Isso ocorre porque se o projeto vem em 2D, eles terão que prever um tempo e esforço não existente anteriormente para realizarem a modelagem 3D antes de iniciar a obra, só então depois conseguem manusear o modelo para os fins desejados, como na gestão do canteiro, no planejamento 4D, na extração de quantitativos para a compra, dentre outros aspectos. Apesar disso, para os poucos casos em que eles também são responsáveis pela contratação do projeto, estão mapeando as necessidades que eles possuem nos modelos para poderem definir as questões contratuais e exigências.

Apesar das empresas terem começado a aprender um pouco melhor o que deve ser solicitado na contratação de projetos e obras BIM, as questões referentes às necessidades de interoperabilidade, comunicação, dados, compartilhamento, trabalho colaborativo, medição e pagamento ainda são questões que precisam ser exploradas por todas elas para compreenderem melhor o que e o como isso deve ser solicitado nos contratos. Além disso, outras informações relevantes devem ser estabelecidas para a subcontratada ao se contratar um projeto BIM, como o nível de qualidade, o conhecimento técnico da equipe, as entregáveis e o compartilhamento de informações entre as empresas envolvidas.

Por fim, faz-se necessário controlar a implantação do BIM e dos projetos para garantir que a qualidade, a troca de dados, as reuniões e as revisões dos projetos ocorram conforme planejado previamente. Só com essa coordenação do processo será possível manter vivo os objetivos idealizados pela implementação, as necessidades em cada momento do trabalho com o compartilhamento do modelo entre diversas empresas, o prazo previsto, a efetividade dos planos de treinamento, do projeto-piloto e da mudança cultural da empresa. Essa etapa é fundamental para entender os benefícios e poder medi-los posteriormente. Apesar das organizações dos estudos de caso não terem definido todo o planejamento crucial para o início do projeto de implantação, as quatro monitoraram de perto os projetos-pilotos e tentaram extrair indicadores ou resultados qualitativos dessas experiências.

Para isso, a figura do Gerente BIM é fundamental. Na Empresa 2 esse profissional foi responsável pela coordenação da área de implantação de inovações na empresa. Então, em certo grau, ele norteou a implementação do BIM na organização, buscou o investimento em hardware para a criação da Sala BIM, 
acompanhou os projetos-pilotos e deu suporte à equipe de projeto. Além disso, essa companhia percebeu após o primeiro projeto-piloto a necessidade de formalizar um responsável para gerenciar cada projeto, conforme se pode ver no Quadro 5, para ficar responsável pela etapa de planejamento, que previa ao início do projeto, o levantamento das necessidades para o desenvolvimento dele, a identificação das informações mínimas, o desenvolvimento do cronograma, garantir a qualidade do modelo, prever e conduzir as reuniões de projeto, garantir a boa comunicação entre os envolvidos e realizar a compatibilização dos projetos.

Já o Gerente BIM responsável pela área de adoção do BIM na Empresa 3 se mostrou mais ativo que o da Empresa 2. Ele acompanhou por um ano in loco o primeiro projeto-piloto da empresa, coordenou a contratação da consultoria para a implantação do projeto BIM na obra e outras necessidades ao longo do desenvolvimento, se encarregou de coordenar a equipe do corporativo a criar materiais internos sobre o método, foi responsável por fomentar o BIM dentro da empresa, trouxe a informação do que é o BIM para a organização forma de apresentação após o projeto-piloto, dentre diversas outras frentes de atuação que se propôs.

Na Empresa 4 criaram uma equipe para coordenarem a implantação do BIM na empresa, por ações de instrução, benchmarking, levantamento de informações e melhorias internas, dentre outras frentes. Porém, após o primeiro ano do projeto de implementação do método na organização, perceberam a necessidade de um responsável pelo projeto e contrataram um Gerente BIM também. Já a Empresa 1 começou a implantação do BIM com a contratação desse tipo de profissional para nortear e estruturar todo o processo de adoção do método em uma área específica. Independente da percepção diferenciada entre as empresas referente ao momento ideal de definição do Gerente BIM, todas elas conseguiram identificar a grande relevância desse tipo de profissional. 


\subsubsection{O Projeto-piloto}

A escolha do projeto-piloto é fundamental para a aplicação e a compreensão do processo BIM pela empresa, além de ser um momento de grande importância, por ser o primeiro em que os colaboradores daquela instituição estão tendo o contato com o método e suas ferramentas. Esse deve ser um período de análise minuciosa para a identificação do melhor projeto para começar a testar o BIM, devendo ele ter o potencial de trazer respostas para os métodos de contratação das etapas de serviços que necessitam ser terceirizados, a identificação dos usos a serem empregados pela empresa, a necessidade de informações que o modelo deverá conter para que os usos almejados sejam possíveis.

Quando o Projeto-piloto é bem estruturado, ou seja, há uma escolha correta de acordo com as melhores práticas identificadas por CBIC (2016b), por exemplo, com metas e objetivos bem definidos, estruturação do plano de coordenação e controle, previsão de métricas para a medição de benefícios, entre outras questões de planejamento e gestão de projetos, ele pode trazer os benefícios esperados e pode atingir as expectativas parcialmente ou completamente.

O projeto-piloto da empresa 3 foi a experiência mais insatisfatória entre aqueles relatados por todas as organizações, visto que a companhia enfrentou uma série de obstáculos intrínsecos daquela tipologia de projeto e contratação. A elevada complexidade do projeto já foi um desafio para a empresa, mesmo sem a implantação de um novo método no processo de trabalho. O prazo curtíssimo de obra solicitado pelo contratante também foi uma dificuldade para o próprio processo convencional da organização. A grande quantidade de projetos desatualizados no início das obras foi outro grande obstáculo, assim como a mesma proporção de projetos sendo atualizados em 2D. Outro ponto foi a falta de comunicação e negociação com o contratante, gerando a necessidade de modelar todos esses projetos em 2D revisados, para que o processo de implantação do 4D e 5D na obra fosse possível. 
Por todos os pontos acima mencionados, os colaboradores envolvidos da Empresa 3 já estavam com uma pressão relevante nas suas cargas de trabalho, portanto quando foi proposto que eles aprendessem a utilizar uma nova ferramenta para fazer o trabalho deles, a recusa foi unânime. Não foi possível realizar a extração de quantitativos para a obra devido à falta de confiabilidade do modelo que estava sendo desenvolvido durante a construção, ao invés de previamente.

O 4D teve que ser desenvolvido pela consultora e o treinamento da equipe da obra não foi feito por recusa dos colaboradores, inclusive do gestor da obra. $A$ falta de suporte da alta hierarquia em relação ao projeto de implantação do BIM permitiu que o novo gestor da obra retirasse qualquer processo BIM previamente estabelecido.

Os projetos-pilotos da Empresa 2 permitiram que a organização e os colaboradores envolvidos aprendessem bastante sobre as ferramentas e como manuseá-las, porém o processo colaborativo proposto pela plataforma BIM não foi reconhecido, tendo em vista a utilização do método da Sala BIM. A colaboração entre diversos stakeholders, em locais fisicamente diferentes e atuando no mesmo modelo paralelamente é uma das grandes vantagens do método, porém a consultoria contratada e a Empresa 2 negligenciaram essa característica tão importante do BIM.

Como os profissionais da segunda empresa encararam o projeto-piloto como uma mera experiência de aprendizado das ferramentas na prática, encontraram muitas dificuldades devido ao planejamento precário do primeiro projeto-piloto. Começaram a entender um pouco melhor as necessidades dos projetos BIM com o andamento dos próximos projetos semelhantes e, assim, foram adequando-se ao processo de trabalho com o método. Apesar do método da Sala BIM funcionar, ele não é o ideal para a organização, visto que a sua atividade principal será a de validação e revisão dos modelos criados e alterados por companhias subcontratadas localizadas em espaços fisicamente diferentes, portanto a aprendizagem sobre o processo colaborativo para eles era algo essencial, tendo que aprender na prática quando houver a contratação de um projeto BIM.

O projeto-piloto da empresa 4 foi acompanhado por pouco tempo, porém as profissionais sempre se referiram a ele como uma experiência para o mapeamento de necessidades, o que aparentemente indica que não há o objetivo de melhorar a qualidade e o prazo das obras nesse momento. Nesse caso, o projeto-piloto não 
está sendo usado para implantar o processo BIM, mas sim para testar o que funciona ou não, com os sistemas existentes da empresa de compartilhamento de dados, comunicação e gestão e com as dificuldades que os profissionais das obras terão em um primeiro momento de contato com o BIM. Outro motivo pelo qual desenvolveram esse projeto-piloto foi pela ansiedade da alta hierarquia em divulgar externamente o fato da empresa estar inovando e internamente para alimentar a ambição dos colaboradores. Hoje o foco da companhia é estruturar o Roadmap da implantação do BIM o mais assertivo possível, para então buscar os benefícios mapeados posteriormente.

O projeto-piloto da Empresa 1 (GPR) foi desenvolvido corretamente, tendo uma tipologia típica e complexidade moderada. Aparentemente os profissionais estavam preparados e treinados para a revisão e a validação do modelo BIM das diferentes disciplinas. Isso ocorreu porque o Gerente BIM promoveu treinamentos internos ministrados por ele mesmo, deu suporte técnico para os profissionais e instituiu o processo BIM dentro da área corretamente. Ainda foi possível extrair índices de resultados ao final do projeto-piloto, o que serviu para identificar alguns ganhos em qualidade e tempo de projeto.

\subsubsection{As pessoas e a rejeição à mudança}

Conforme citado na revisão bibliográfica, a indústria AEC possui uma grande quantidade de pessoas envolvidas (CATELANI; SANTOS, 2016). Por esse motivo é essencial que eles entendam qual será o impacto no dia a dia de trabalho desses colaboradores frente à mudança proposta e como prepará-los da melhor forma possível para recebê-la de uma boa maneira.

Quando não se explica a mudança de trabalho para o colaborador e o impacto, a incerteza cresce para os profissionais, o que gera a rejeição à mudança e dificulta ainda mais o processo de implantação (CBIC, 2016b; CÂNDIDO; ABREU, 2002). Portanto, por não ter sido tratado esse tema nas Empresas 2 e 3 antes e durante o projeto-piloto. Esse fenômeno foi ainda mais forte e trouxe uma rejeição à alteração maior do que nas outras. Os cinco componentes críticos para evitarem a rejeição à mudança citados por CBIC (2016b) são: visão, capacitação, incentivos, recursos e ter um plano de ação, ou seja, são essenciais para evitarem esse tipo de obstáculo na adoção do BIM. 
Todas as empresas se preocuparam com o componente da capacitação, desenvolvendo treinamentos nas ferramentas para os colaboradores de alguma forma, seja pela contratação externa ou internamente. Os softwares já estavam contratados nas empresas devido à compra do pacote de licenças da Autodesk, então esse recurso esteve presente a todos os momentos. Os hardwares foram rapidamente adaptados ou trocados nas empresas. Apenas a organização 2 teve que fazer a estruturação de uma nova sala, com novos computadores, o que fez com que demorasse por um longo período. Então, de maneira geral, as quatro companhias conseguiram os componentes críticos relativos aos recursos e à capacitação.

O grande problema nas empresas dos estudos de caso e que se repete no mercado é a falta de visão. Os colaboradores não possuem o conhecimento do que é o BIM e o como o seu processo de trabalho será afetado, até mesmo porque existe uma certa dificuldade na compreensão do método, conforme citado nesta seção. Então, antes de treinar esses profissionais, as empresas precisam muni-los de conhecimento sobre o método, o que ela representa para o processo de trabalho e o que é esperado com essa mudança, como as Empresas 1 (Inovação BIM) e 4 fizeram com os seus circuitos de palestras. Basicamente o colaborador precisa se sentir incluído no processo de adoção pela comunicação transparente e um plano de ação, com espaço para tirar suas dúvidas e expor suas ideias sobre o tema.

No caso da Empresa 3, eles tentaram implantar o BIM na obra do projetopiloto sem a compreensão do método pelos engenheiros responsáveis, nem pelo gerente da obra. Decidiram treinar esses profissionais durante o período de trabalho deles, quando estavam preocupados com o andamento da obra e a resolução de problemas in loco, portanto não possuíam tempo para o aprendizado proposto. Assim, fica claro que não houve planejamento para essa implantação e o que gerou os cinco pontos da rejeição à mudança pelos profissionais dessa obra.

Um aspecto que ajudou a Empresa 4 a encontrar uma resistência menor à mudança, além do circuito de palestra que desenvolveram para seus colaboradores, foi a cultura já instituída na empresa voltada para as inovações. Com as áreas de excelência criadas dentro da organização, os profissionais internamente estão sempre buscando uma maneira de fazer diferente e melhor, portanto, o colaborador dessa companhia já está condicionado a aceitar ou aceitar mais facilmente a mudança quando ela aparece. 


\subsubsection{A Gestão de Projetos}

A adoção do BIM em uma empresa nada mais é do que um projeto, que para ser mais eficiente e eficaz deve ser formalmente documentado e seguir as melhores práticas contidas no PMBOK (PMI, 2013). Esse mapeamento de necessidades e entendimento sobre o BIM faz parte do planejamento do processo, etapa crucial para a eficácia deste projeto, conforme identificado Cândido e Abreu (2002), Silva e Gil (2013), CIC (2010), Eastman et al. (2014), CBIC (2016b), PMI (2013), MDIC (2018c) e CBIC (2016a). Alguns dos pontos cruciais Gestão de Projetos durante a Implantação do BIM que algumas empresas seguiram constam na Figura 47.

Figura 47 - A Implantação do BIM e a Gestão De Projetos

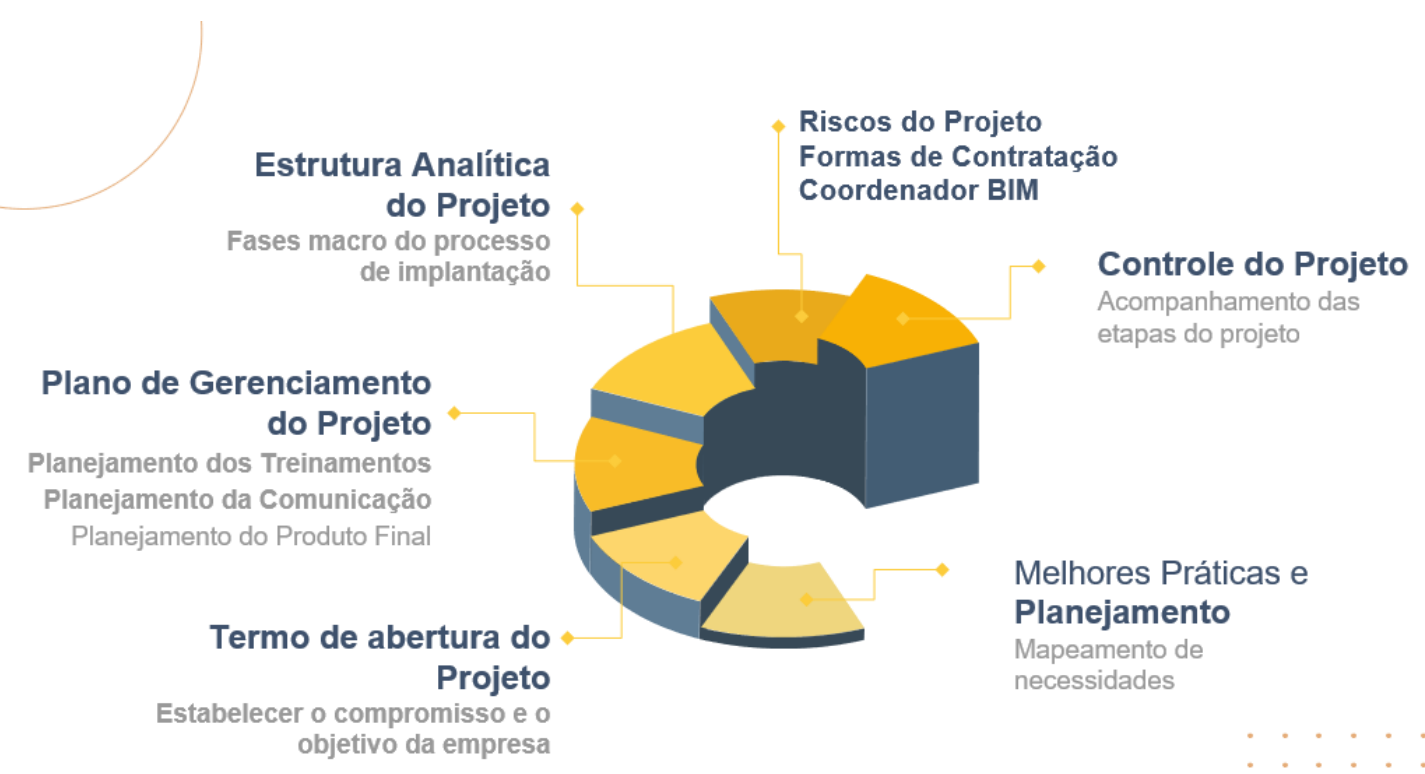

Fonte: A autora (2019)

A falta de planejamento das 10 etapas macro de adoção do BIM citadas por CBIC (2016b) foi o principal motivo da frustração de todas as empresas dos estudos de caso. Durante a idealização do Plano de Adoção do BIM nas organizações, deveria ter sido desenvolvido o Termo de abertura do Projeto para estabelecer o compromisso e o desejo da empresa com a realização desse projeto e assim dar maior motivação e poder à equipe responsável, evitando as recusas de participação como as situações que ocorreram com os projetos piloto das empresas 2 e 3 . Além 
disso, para o desenvolvimento desse tipo de documento, é necessário estabelecer informações cruciais do planejamento e as próximas etapas, sendo, no caso do Plano BIM, questões como definição dos objetivos com a implantação, quais os usos a serem implantados, benefícios esperados e estabelecer as premissas do projeto.

Após o desenvolvimento desse documento inicial, as empresas deveriam seguir para o Plano de Gerenciamento do Projeto, conforme citado na bibliografia PMI (2013), que faz a integração de todos os aspectos a serem planejados para o projeto ter o sucesso esperado, prevendo como ele deverá ser executado, monitorado e controlado, variando no seu conteúdo. Para o Plano BIM seria importante prever planos auxiliares, como, por exemplo:

a) Planejamento dos treinamentos: refletir sobre a necessidade de treinamentos para cada um dos colaboradores, de acordo com suas atividades a performar, ao invés de gastar tempo e dinheiro treinando um profissional em uma ferramenta que não será utilizada por ele, o que não foi desenvolvido por nenhuma das empresas. Na Empresa 1 o gerente treinou a equipe no software principal que eles utilizariam e na ferramenta de comunicação com a subcontratada. A Empresa 2 contratou a consultoria que deu os treinamentos para diversos profissionais antes do início dos projetos-pilotos e depois acompanhou dando suporte técnico para os que atuaram; a terceira instituição contratou uma empresa que deu treinamentos macro de algumas ferramentas para diversos profissionais e alguns treinamentos mais específicos em algumas ferramentas, focado para outros colaboradores. Já a empresa 4 optou por buscar o conhecimento por diversas fontes diferentes, como mestrado, MBA e cursos sobre o BIM e depois compartilhar o conhecimento internamente, sendo que o conhecimento nas ferramentas ficou a cargo de cada profissional aprender por conta própria, até que eles tivessem desenhado o Plano de adoção BIM na empresa.

b) Planejamento da comunicação: questões relacionadas ao compartilhamento de informações internamente entre os diferentes colaboradores e áreas; e externamente com as empresas subcontratadas. Periodicidade, ferramentas, forma, informações a serem trocadas, plataforma de troca de arquivos, entre outras questões. Esse foi um dos problemas identificados pela Empresa 4 durante a fase de investigação desenvolvida pela equipe, percebendo que 
para implantar o BIM precisariam reestruturar a forma como a informação e os arquivos dentro da empresa são compartilhados. A Empresa 1 (GPR) definiu todo o processo de comunicação, responsáveis pelas informações a serem trocadas, entre outras questões, no BEP que desenvolveram em parceria com as subcontratadas. Além disso, eles também definiram que os apontamentos no modelo para as revisões seriam feitos no padrão BCF. No Inovação BIM da Empresa 1, foi desenvolvido um Plano formal de Comunicação, que é o ideal para que todos os colaboradores da empresa tivessem essa necessidade destacada e definida de maneira transparente $e$ simples.

c) Planejamento do modelo a ser entregue/necessário/contratado: isso nada mais é do que as necessidades a serem previstas no contrato e o que deverá conter no BEP após a contratação para a definição de responsáveis, datas, fluxos, forma de trabalho, dentre diversas questões. As quatro empresas entrevistadas desenvolveram esse documento em fases diferentes, mas a relevância dele foi identificada durante todas as experiências.

A Estrutura Analítica do Projeto de implantação do PMI (2013) indica que deverá ser desenvolvido um documento bastante relevante para organizar a implantação do projeto, prevendo cada uma das fases macro e dividindo em ações menores para se chegar ao objetivo, tornando, assim, visual a progressão do projeto e as necessidades para a implantação. A Empresa 1 (Inovação BIM) desenvolveu a EAP do seu projeto, ilustrado na Figura 27, para um melhor acompanhamento e clareza das atividades a serem desenvolvidas, para que a empresa consiga implantar o BIM efetivamente. Na EAP já está previsto x’o sequenciamento das atividades, que deverão ser planejadas para cada uma das ações dos recursos necessários.

Após esse documento é importante mapear os riscos do projeto, as contratações que serão necessárias, o plano de comunicação e as formas de contratação de fornecedores, o que não foi definido por nenhuma das quatro empresas durante os estudos de caso, nem foi previsto. Já o cronograma de implantação também planejado no PMBOK, está sendo desenvolvido pela Empresa 1 (Inovação BIM), na qual estão mapeando todas as necessidades do projeto para então conseguirem estimar o tempo dessa implantação. A Empresa 4 possui um 
prazo definido, devido ao seu plano trienal, portanto, após o primeiro ano de busca de informações e estruturação do plano de adoção do BIM, sobraram dois anos para eles implantarem o BIM em toda a organização. As empresas 2 e 3 não possuem plano de implantação, portanto, não previram um cronograma.

Durante a adoção do BIM é importante que tenha um profissional responsável por esse projeto para verificar se as ações, o prazo e as definições estão sendo corretamente cumpridos. O acompanhamento desse processo para garantir a efetividade dele e evitar frustrações é fundamental pela empresa responsável. A falta de estruturação de um projeto formal de implantação pelas empresas 2 e 3 faz com que fique um pouco difícil de identificar os próximos passos, organizar o que deve ser feito e o tempo em que tudo isso deve acontecer. As Empresas 1 e 4 estão com um foco muito grande no acompanhamento desse processo de implantação e no controle, por ser fundamental para o sucesso do projeto e garantir que o que foi planejado está sendo cumprido. O controle da qualidade e a mensuração do atingimento das metas também deverá ser feito para apresentar os resultados do projeto. Para isso, será necessário definir indicadores do processo de projeto ou obra da maneira tradicional e colher após o projeto os mesmos índices. 


\section{CONCLUSÕES}

A partir dos quatro estudos de caso e da revisão bibliográfica foi possível analisar os processos de adoção do BIM desenvolvidos e as recomendações dos autores, para entender, na prática, o que o cumprimento ou não dessas orientações impactam no resultado do processo. Apesar da pequena amostra, é possível ver que o processo de adoção do BIM ainda é um tema que precisa ser explorado devido às incertezas e às dificuldades encontradas ao longo do caminho. $\mathrm{O}$ assunto está em evidência no segmento da construção civil global e ainda é acompanhado para entender o seu comportamento e as decisões relevantes frente ao tema.

Na revisão bibliográfica é possível constatar uma evolução sobre o tema ao longo dos anos, a tomada de consciência dos autores em relação ao que esse método representa e as dificuldades que as empresas têm em implantar o BIM. Também fica claro que muitos países estão a cada dia mais buscando implementar a sua indústria $A E C$, porque percebem a necessidade de mudarem os processos e a maneira de fazer que não se altera há muitos anos.

Com o trabalho desenvolvido foi possível concluir que a escolha de quem conduzirá a implantação do BIM na empresa é a mais importante no processo de adoção do método e que será determinante para definir o sucesso desse projeto. $O$ Gerente BIM deverá possuir habilidades em Gestão de Projetos, o que será crucial para desenvolver a implantação na empresa e os conhecimentos específicos sobre - BIM, para entender as etapas, o amadurecimento necessário, os recursos previstos, a mudança no processo de trabalho, dentre outras questões abordadas neste estudo.

Isso fica ainda mais claro quando percebemos que todas as empresas passaram por alguns anos de reconhecimento sobre o BIM, mas só realmente começam o processo de adoção na empresa quando contratam um responsável, ou designam uma equipe interna com este fim. Isso ocorre porque o foco desse profissional dentro da organização será o de planejar tudo que precisa ser feito, pesquisar mais sobre o assunto, desenvolver ações focadas na implantação, tomar decisões, fazer solicitações à alta hierarquia, dentre diversas outras atribuições desse profissional. Tudo isso ocorre porque o sucesso desse processo de adoção será totalmente responsabilidade dele. 
Por esse motivo a escolha desse profissional é tão importante nesse processo. Logo as empresas deverão ter muito cuidado nessa escolha e ter em mente que o profissional não precisa ser um especialista nas ferramentas, mas sim na gestão de projetos focada em BIM.

A gestão de projetos nesse processo é crítica para alcançar os objetivos que as empresas buscam, de aumento de produtividade, melhoria da qualidade do produto e diminuição de prazos. Aqui também está contida a definição dos objetivos da implantação do BIM, a verificação da viabilidade deles, levando em conta as possibilidades do método e o plano de implantação a ser desenvolvido. Ter a clareza do que será implantado, o como e o porquê, é importante para entender o que precisa ser feito, questionando a necessidade da proposta e compreender o que é realmente necessário e compreender o caminho que será possível trilhar para isso. A gestão dos projetos também definirá os processos para se trabalhar com dentro de cada empresas, os procedimentos de comunicação, os fluxos do trabalho, da informação, dos dados e do modelo, por isso, o planejamento estratégico é essencial.

Igualmente importante nesse processo é prover o conhecimento aos colaboradores da empresa. Não só o conhecimento técnico, como treinamento nas ferramentas, mas, principalmente, o conhecimento sobre o que o BIM representa, os diversos campos de aplicação, como ele muda o processo de trabalho, quais são os benefícios que ele pode trazer para o projeto e para cada um dos profissionais nas suas rotinas de trabalho. A preparação das pessoas para a mudança é crucial para que o plano de adoção do BIM avance, conforme previsto dentro da empresa, porque sem o suporte da equipe interna e a motivação dos profissionais, os resultados demorarão muito mais tempo para acontecer. Além disso, sem essa preparação, a implantação do BIM pode ser falha e não ter resultados favoráveis, levando a empresa a abandonar o projeto.

A formalização do plano de adoção do BIM e dos planos complementares, a disponibilização desses e a comunicação com os colaboradores da empresa também é importante para garantir que todos tivessem o conhecimento dos objetivos da empresa e pudessem se adequar. Além disso, é fundamental para o progresso de qualquer projeto o planejamento do que deverá ser desenvolvido, o acompanhamento da execução e o controle do processo. 
Outra questão importante é a forma de contratação, tema pouco explorado ainda no país, visto que como todo o processo se altera, inclusive o produto final, é necessário definir na contratação o que se espera para garantir que haja alinhamento entre as partes, evitando frustrações. Se a forma de contratar, o processo e o produto se alteram, os modos de pagamento desse projeto ou obra também deverão sofrer alteração de acordo com as novas características do processo.

Independente do foco da empresa, seja ela de infraestrutura, residencial, comercial, dentre outras, o processo de adoção do BIM deve seguir as mesmas questões referentes ao planejamento, estruturação, cuidado com os colaboradores, implantação e controle. O que muda entre essas empresas são a complexidade do seu negócio e do produto, o que pode impactar ainda mais o processo de adoção do BIM por uma questão intrínseca à natureza do negócio da empresa, porém não é o fator determinante para o sucesso da implantação. Os processos internos e as ferramentas evidentemente mudam de uma operação para outra, sendo essas com a mesma atuação ou em segmentos diferentes.

A mudança que o BIM traz para o processo inteiro da cadeira produtiva da construção civil exige que o mercado se reestruture, as fases do ciclo de vida do empreendimento mudem, as empresas ofereçam novos produtos e serviços, as formas de contratação se alterem, os sindicatos e instituições relevantes para a Indústria AEC mapeiem essas mudanças e norteiem as empresas do setor. Quanto mais tempo essa reestruturação demorar para se concretizar, maior será o tempo que as empresas também levarão para se adequarem à nova realidade, por isso é tão importante a estratégia nacional de implantação do BIM.

\subsection{Recomendações}

A partir desse estudo exploratório nas empresas e a identificação dos resultados, recomenda-se dar a importância devida para o processo de adoção do BIM nas empresas, realizando um planejamento estratégico diferenciado e focado no sucesso do projeto, que busquem a contratação de ajuda interna e externa para isso, tanto contratando especialistas e gerentes BIM, quanto consultorias sérias para darem apoio sobre o tema. 
Ainda se deve buscar o apoio das grandes instituições da indústria AEC para verificar as recomendações e as melhores práticas para entender sobre o tema, buscar treinamentos e seguir métodos de implantação previamente testados e com a sua efetividade comprovada, conforme relatado em diferentes bibliografias. Ao se tomar a decisão de implantar o BIM, as empresas devem ter a certeza da revolução que isso representará nos seus negócios e ter o conhecimento da paciência que precisarão ter até a implantação chegar no nível necessário para que o método comece a trazer os benefícios esperados.

Antes de começar os testes e o aprendizado prático pelos projetos-pilotos, as empresas devem garantir previamente toda a estruturação, planejamento, investimento e disponibilidade dos profissionais para desenvolverem esse serviço. Os objetivos que devem ser alcançados necessitam estar presentes na mentalidade dos profissionais durante todo o processo, portanto, precisam prever como motivar esses colaboradores

É preciso ter em mente que o BIM não é a única revolução que as empresas deverão fazer, sendo necessária a reestruturação sistêmica de todos os softwares já utilizados, a automatização de processos ou etapas manuais, a reestruturação dos fluxos e da comunicação entre os colaboradores e a busca por inovação tecnológica em cada fase do seu processo, para completar cada vez mais a construção virtual antes da real.

\subsection{Sugestões Futuras}

Um dos objetivos desse trabalho foi 0 de motivar as pesquisas complementares ao tema da adoção do BIM nas empresas do segmento da construção civil, para entender cada vez melhor um processo tão complexo, conforme verificado nesta pesquisa.

Os estudos de casos de implantações do BIM nas empresas são essenciais que continuem sendo relatados, para que fique registrado esse momento histórico de transformação da indústria da construção civil. Isso serve para o amadurecimento do processo e pode ser um suporte para as próximas empresas a realizarem este desenvolvimento.

Assim, abaixo são sugeridas algumas possíveis pesquisas futuras de temas que serão relevantes para auxiliarem nessa temática: 
a) Plano de Pessoas para a implantação do BIM, como contornar a rejeição à mudança;

b) Como deve ser composto o currículo de um Gerente BIM, quais são os conhecimentos, as habilidades e as experiências necessárias para o profissional;

c) Diferenças entre um Gerente BIM e um Gestor de Projetos ou um Especialista BIM;

d) Projeto-piloto BIM: planejamento, escolha, acompanhamento, controle e retroalimentação do conhecimento;

e) Obstáculos para a implantação do BIM levantados nessa pesquisa e como resolver cada um deles, de maneira prática e consistente. 


\section{REFERÊNCIAS}

ABDELMOHSEN, S. Genres Of Communication Interfaces In Bim-Enabled Architectural Practice. 2012. Disponível em:

<http://papers.cumincad.org/data/works/att/ascaad2012_009.content.pdf >. Acesso em: 12 set. 2017.

ABNT. Coletânea Eletrônica de Normas Técnicas - Modelagem de Informação da Construção (BIM). 2017. Disponível em:

<https://www.abntcatalogo.com.br/pub.aspx?ID=2951>. Acesso em: 01 jun, 2019.

AIA - American Institute of Architects. Document E202TM - 2008: Building Information Modeling Protocol. 2008. Disponível em:

<https://www.aiacontracts.org/contract-documents/19016-project-bim-protocol>.

Acesso em: 19 abr. 2019.

AZHAR, S. Building Information Modeling (BIM): Trends, Benefits, Risks, and Challenges for the AEC Industry. Leadership and Management in Engineering, v. 11, n. 3, p. $241-251$ jul. 2011. Disponível em:

$<$ https://ascelibrary.org/doi/10.1061/\%28ASCE\%29LM.1943-5630.0000127>.

Acesso em: 10 jul. 2018.

AZHAR, S.; HEIN, M.; SKETO, B. Building Information Modeling (BIM):

Benefits, Risks and Challenges. 2008. Disponível em:

<https://www.sciencedirect.com/science/article/pii/S2212609016302047>. Acesso em: 25 jun. 2018.

BIOTTO, Clarissa Notariano; FORMOSO, Carlos Torres; ISATTO, Eduardo Luis. O uso da modelagem BIM 4D no projeto e gestão de sistemas de produção em empreendimentos de construção. In: XIV Encontro Nacional de Tecnologia do Ambiente Construído - ENTAC 2012. Juiz de Fora, Minas Gerais. 2012. Disponível em:

<http://www.academia.edu/2488000/O_USO_DA_MODELAGEM_BIM_4D_NO_P ROJETO_E_GESTAO_DE_SISTEMAS_DE_PRODDUCAO_EM_EMPREENDIIMEN TOS_DE_CONSTRUCAO>. Acesso em: 28 set. 2014.

CÂNDIDO, G. A.; ABREU, A. F. O Processo de Implantação de Novas Tecnologias e a Busca da Sinergia Entre Indivíduo e Organização. Revista de Ciências da Administração, v. 4, n. 08, 2002. Disponível em: $<$ https://periodicos.ufsc.br/index.php/adm/article/view/1844>. Acesso em: 07 jul. 2018.

CARDOSO, F. F. A Dimensão Organizacional da Construção Civil. In: TIGRE, Paulo Bastos (org.) Setor de Construção Civil: segmento de edificações. Série Estudos Setoriais n. 5. Serviço Nacional de Aprendizagem Industrial. Brasília: Departamento Nacional / SENAI, 2005. p. 71-124.

CARVALHO, H.; SCHEER, S. A utilização de modelos BIM na gestão de resíduos de construção e demolição. In: ENCONTRO BRASILEIRO DE TECNOLOGIA DE INFORMAÇÃO E COMUNICAÇÃO NA CONSTRUÇÃO, 7., 2015, Recife. 
Anais...Porto Alegre: ANTAC, 2015. Disponível em: <http://pdf.blucher.com.br.s3sa-east-1.amazonaws.com/engineeringproceedings/tic2015/022.pdf>. Acesso em: 30 jul. 2018.

CATELANI, W. S.; SANTOS, E. T. Normas brasileiras sobre BIM. Revista Concreto \& Construções. 2016. Edição 84. Pag 54 - 59. Disponível em: $<$ http://ibracon.org.br/Site_revista/Concreto_Construcoes/ebook/edica084/files/ass ets/basic-html/page54.html>. Acesso em: 02 mar. 2018.

CBIC - CÂMARA BRASILEIRA DA INDÚSTRIA DA CONSTRUÇÃO. Fundamentos BIM - Parte 1: Implantação do BIM para construtoras e incorporadoras. Brasília, 2016a. 124 p. CDD:624.05. Disponível em: $<$ https://cbic.org.br/faca-o-download-da-coletanea-bim-no-site-da-cbic/>. Acesso em: 18 mar. 2018.

Implementação do BIM - Parte 2: Implantação do BIM para Construtoras e Incorporadoras. Brasília, 2016b. 72 p. CDD:624.05. Disponível em: <http://sindusconbc.com.br/wp-content/uploads/2016/10/VOLUME-_2.pdf>. Acesso em: 18 mar. 2018.

.Colaboração e integração BIM - Parte 3: Implantação do BIM para construtoras e incorporadoras. Brasília, 2016c. 132 p. CDD:624.05. Disponível em: $<$ https://cbic.org.br/faca-o-download-da-coletanea-bim-no-site-da-cbic/>. Acesso em: 18 mar. 2018.

.Fluxos de Trabalho BIM - Parte 4: Implantação do BIM para construtoras e incorporadoras. Brasília, 2016d. 100 p. CDD:624.05. Disponível em: $<$ https://cbic.org.br/faca-o-download-da-coletanea-bim-no-site-da-cbic/>. Acesso em: 18 mar. 2018.

.Formas de Contratação BIM - Parte 5: Implantação do BIM para construtoras e incorporadoras. Brasília, 2016e. 104 p. CDD:624.05. Disponível em: $<$ https://cbic.org.br/faca-o-download-da-coletanea-bim-no-site-da-cbic/>. Acesso em: 18 mar. 2018.

.10 motivos para evoluir com o BIM. Brasília, 2016f. 28 p. CDD:624.05. Disponível em: <https://cbic.org.br/faca-o-download-da-coletanea-bim-no-site-dacbic/>. Acesso em: 18 mar. 2018.

\section{Manaus Sedia O Quarto Workshop De Implementação Do BIM} Voltado À Cadeia Produtiva Da Construção. 2017a. Disponível em: <http://www.cbic.org.br/sala-de-imprensa/noticia/manaus-sedia-o-quartoworkshop-de-implementacao-do-bim-voltado-a-cadeia-pro> Acesso em: 15 maio 2017.

Manual básico de indicadores de produtividade na construção civil Volume 1. Brasília, DF: CBIC, 2017b. 92 p. Disponível em: <https://cbic.org.br/wpcontent/uploads/2017/11/Manual_Basico_de_Indicadores_de_Produtividade_na_C onstrucao_Civil_2017.pdf>. Acesso em: 27 maio 2018. 
.Com Apoio da CBIC, Building Information Modeling (BIM) Avança no

Brasil. CBIC website. 2017c. Disponível em: <https://cbic.org.br/com-apoio-dacbic-building-information-modelin-bim-avanca-no-brasil> Acesso em: 24 jul. 2017.

.BIM: Oportunidade para inovar a indústria da construção e aumentar a transparência das compras públicas. 2018a. Disponível em:

$<$ https://cbic.org.br/inovacao/2018/03/02/bim-oportunidade-para-inovar-a-industriada-construcao-e-aumentar-a-transparencia-das-compras-publicas/> Acesso em: 29 jul. 2018.

. Decreto Presidencial inaugura política para democratizar o uso do BIM. 2018b. Disponível em: <https://cbic.org.br/decreto-presidencial-inaugurapolitica-para-democratizar-o-uso-do-bim/>. Acesso em: 12 jul, 2018.

Política Nacional de Disseminação do BIM é debatida no $90^{\circ}$ ENIC. 2018c. Disponível em: <https://cbic.org.br/politica-nacional-de-disseminacao-dobim-e-debatida-no-90-enic/> Acesso em: 08 jul. 2018.

CHENG, J. C. P.; MA, L. Y. H. A BIM-based system for demolition and renovation waste estimation and planning. In: International Conference on Computing in Civil and Building Engineering, 14. 2012. Moscou, Rússia. Anais... Disponível em: <https://meyar.co/wp-content/uploads/2017/02/A-BIM-based-system-fordemolition-and-renovation.pdf>. Acesso em: 12 jul. 2018.

CIC - Computer Integrated Construction Research Program. BIM Project Execution Planning Guide - Version 2.0. 2010. The Pennsylvania State University. Pensilvânia, Estados Unidos. Disponível em:

<http://bim.psu.edu/project/resources/>. Acesso em: 13 mar. 2018

CNI - Confederação Nacional da Indústria. CBIC e SENAI promovem workshop sobre implementação do BIM. 2017. Disponível em:

<http://www.portaldaindustria.com.br/agenciacni/noticias/2017/09/cbic-e-senaipromovem-workshop-sobre-implementacao-do-bim/>. Acesso em: 09 jun. 2018

CORAL, E.; OGLIARI, A.; Abreu, A. F. Gestão integrada da inovação: estratégia, organização e desenvolvimento de produtos. São Paulo: Atlas. ISBN 978-85224497-6-7., 2008.

CRC - Cooperative Research Centre for Construction Innovation. Adopting BIM for facilities management: Solutions for managing the Sydney Opera House. 2007. ISBN 978-0-9775282-2-6. Disponível em: <https://eprints.qut.edu.au/27582/>. Acesso em: 03 jun. 2018.

CTE - Centro de Tecnologia de Edificações. 5 Seminário Internacional BIM terá palestra do professor Rafael Sakcs do MIT. 2014. Disponível em: <http://www.cte.com.br/noticias/2014-09-175o-seminario-internacional-bim-terapale/>. Acesso em: 05 jun. 2018. 
EASTMAN, C. et al. Manual de BIM: Um Guia de Modelagem da Informação da Construção para Arquitetos, Engenheiros, Gerentes, Construtores e Incorporadores. Porto Alegre: Bookman, 2014. 483 p. ISBN: 978-85-8260-118-1.

FIESP - Federação das Indústrias do Estado de São Paulo. Construbusiness: $12^{\circ}$ Congresso Brasileiro da Construção. 12. ed. São Paulo: Federação das Indústrias do Estado de São Paulo, 2016.

FERREIRA, A. V.; ZANCUL, E. Estudo sobre produtividade na construção civil: desafios e tendências no Brasil. 2016. Disponível em: $<$ https://www.ey.com/Publication/vwLUAssets/EY_Estudo_Produtividade_na_Cons trucao_Civil/\$FILE/Estudo_Real_Estate.pdf>. Acesso em: 17 jun. 2018.

FREITAS, E. C.; PRODANOV, C. C. Metodologia do Trabalho Científico: Métodos e Técnicas da Pesquisa e do Trabalho Acadêmico. 2. ed. Novo Hamburgo: Feevale, 2013. ISBN 978-85-7717-158-3.

FREITAS, R. C. F.; MELHADO, S. B. O processo de adoção do BIM em uma construtora de grande porte de São Paulo. In: ENCONTRO NACIONAL DE TECNOLOGIA DO AMBIENTE CONSTRUÍDO, 18., 2018, São Paulo. Anais... Porto Alegre: ANTAC, 2018.

FREITAS, R. C. F.; MELHADO, S. B.; CARDOSO, F. F. Os desafios e os esforços da cadeia produtiva da construção civil para a adoção do BIM. In: ENCONTRO NACIONAL DE TECNOLOGIA DO AMBIENTE CONSTRUÍDO, 18., 2018, São Paulo. Anais... Porto Alegre: ANTAC, 2018.

GERHARDT, T. E.; SILVEIRA, D. T. Métodos de Pesquisa. Porto Alegre: Editora da UFRGS, 2009. 120 p. ISBN 978-85-386-0071-8.

HALLBERG, D.; TARANDI, V. On the use of open BIM and 4D visualization in a predictive life cycle management system for construction works. ITcon, v. 16, p. 445-4662011. Disponível em:

<https://www.itcon.org/papers/2011_26.content.05100.pdf>. Acesso em: 05 mar. 2019

HARDIN, B.; MCCOOL, D. BIM and Construction Management: Proven Tools, Methods and Workflows. 2. ed. Indianapolis, Indiana, Estados Unidos: John Wiley\& Sons Inc, 2015. 363 p. ISBN: 978-1-118-94276-5. Disponível em: <http://iibimsolutions.ir/files/BIM/Ebook/BIM\%20and\%20Construction\%20Manage ment-2nd\%20edition.pdf>. Acesso em: 24 jul. 2016.

KAMARDEEN, I. 8D BIM Modelling Tool for Accident Prevention through Design. In: ANNUAL ARCOM CONFERENCE, 26., 2010. Leeds, Inglaterra. Association of Researchers in Construction Management, 2010. P. 281-289. Disponível em: $<$ http://citeseerx.ist.psu.edu/viewdoc/download?doi=10.1.1.461.8274\&rep=rep1\&ty pe=pdf>. Acesso em: 22 jun. 2016. 
Disponível em:

$<$ http://sectordialogues.org/sites/default/files/acoes/documentos/bim.pdf >. Acesso em: 24 set. 2017.

KELLY, G.; SERGINSON, M.; LOCKLEY, S.; DAWOOD, N.; KASSEM, M. BIM for facility management: a review and a case study investigating the value and challenges. In: 13th International Conference on Construction Applications of Virtual Reality. Inglaterra, Londres: 2013. Disponível em: <http://itc.scix.net/data/works/att/convr-2013-20.pdf>. Acesso em: 30 jul. 2018.

KUNZ, J. FISCHER, M. Virtua0I Design and Construction: Themes, Case Studies and Implementation Suggestions. California. 2009. Stanford University: Center for Integrated Facility Engineering.

MANZIONE, L. Proposição de uma Estrutura Conceitual de Gestão do Processo de Projeto Colaborativo com o uso do BIM. Tese (Doutorado em Engenharia) - Universidade de São Paulo, São Paulo, 2013.

McGraw Hill Construction. The Bussiness Value of BIM for Construction in Major Global Markets. 2014. Smart Martket Report. Disponível em: <https://www.icn-solutions.nl/pdf/bim_construction.pdf>. Acesso em: 05 jun. 2018.

Mapa Metro. Sistema de metrô de Salvador e Lauro de Freitas. 2014. Site. <http://mapa-metro.com/pt/brasil/salvador/metro-bahia-mapa.htm>. Acesso em: 04 mar, 2018.

MCT. Ministério da Ciência e Tecnologia, Secretaria de Política Tecnológica Empresarial. Necessidades de ações de desenvolvimento tecnológico na produção da construção civil e da construção habitacional. Texto-base de workshop de mesmo nome. Brasília, 2000.

\section{MCTIC. ESTRATÉGIA NACIONAL DE CIÊNCIA, TECNOLOGIA E INOVAÇÃO} 2016-2022. 2016. Disponível em: <http://www.finep.gov.br/images/afinep/Politica/16_03_2018_Estrategia_Nacional_de_Ciencia_Tecnologia_e_Inovac ao_2016_2022.pdf>. Acesso em: 10 fev. 2019

MDIC - Ministério da Indústria, Comércio Exterior e Serviços. Estratégia Nacional de Disseminação do BIM - Estratégia BIM BR. MDIC website. Brasília, 2018a. Disponível em <http://www.mdic.gov.br/index.php/competitividade-industrial/cebim>. Acesso em: 10 jun. 2018.

Comitê Estratégico de Implementação do BIM (CE-BIM). MDIC website. Brasília, 2018b. Disponível em $<$ http://www.mdic.gov.br/index.php/noticias/3317-comite-estrategico-deimplementacao-do-bim-ce-bim>. Acesso em: 06 jun. 2018.

ESTRATÉGIA BIM BR: Estratégia Nacional de Disseminação do Building Information Modelling. 2018c. Disponível em: <http://www.mdic.gov.br/images/REPOSITORIO/sdci/CGMO/Livreto_Estratgia_BI M_BR-6.pdf>. Acesso em: 13 jun. 2019. 
MELHADO, S.B.; OLIVEIRA, O. J. Como Administrar Empresas de Projeto de Arquitetura e Engenharia Civil. São Paulo: Pini Ltda., 2006. 64 p. ISBN: 857266-167-0.

MITCHELL, D. 5D BIM: Creating Cost Certainty and Better Buildings. 19th CIB World Building Congress. Bribane: 2013.

Disponível em: <https://www.irbnet.de/daten/iconda/CIB_DC27547.pdf>. Acesso em: 07 jul. 2018.

MOAKHER, P. E.; PIMPLIKAR, S. S. Building Information Modeling (BIM) and Sustainability - Using Design Technology in Energy Efficient Modeling. IOSR Journal of Mechanical and Civil Engineering. 2012. Vol. 1. 2 ed. 10-21 p. ISSN : 2278-1684. Disponível em:

$<$ https://media.thebimhub.com/user_uploads/bim_paper.pdf>. Acesso em: 07 jul. 2018.

MORDUE, S.; SWADDLE, P.; PHILP, D. Building Information Modeling for Dummies. 1.ed. Chichester, ReinoUnido: John Wiley\& Sons, Ltd. 2016. 333p. ISBN: 978-1-119-06007-9.

NASCIMENTO, A. F.; LÜKE, W. G.Iniciativas do Governo Federal para Implantação do BIM no Brasil. In: XIV Encontro Nacional de Empresas Projetistas e Consultores da Abrava. 2014. Brasília. Disponível em: <http://www.abrava.com.br/arquivos/3/c974cbabc93931176029f514fc9e1c7c.pdf>. Acesso em: 02 jun. 2018

PMI. Guia PMBOK: Um guia do conhecimento em gerenciamento de projetos. 5. ed. Project Management Institute. ISBN: 978-1-62825-007-7., 2013.

Presidência da República. DECRETO № 10.306, DE 2 DE ABRIL DE 2020. Disponível em: <http://www.planalto.gov.br/ccivil_03/_ato20192022/2020/decreto/D10306.htm>. Acesso em: 09 abril 2020.

RICS - Royal Institution of Chartered Surveyors. Utilization of BIM in Construction Cost and Project Management Practices: North America, China \& the UK. 2015. Disponível em:

$<$ https://www.isurv.com/downloads/download/1993/utilization_of_bim_in_constructi on_cost_and_project_management_practices_rics>. Acesso em: 05 jul. 2018.

RUSCHEL, R. C. TO BIM OR NOT TO BIM? In: Encontro da Associação Nacional de Pesquisa e Pós-graduação em Arquitetura e Urbanismo. São Paulo: 2014. 14 p.

SINDUSCONSP. Produtividade brasileira na construção ficou abaixo da média mundial na última década. 2015. Disponível em:

<https://www.sindusconsp.com.br/produtividade-brasileira-na-construcao-ficouabaixo-da-media-mundial-na-ultima-decada/>. Acesso em: 02 jun 2018. 
60 Seminário Internacional BIM. São Paulo, 2015. Disponível em: <http://www.sindusconsp.com.br/acontece/7o-seminario-bim-modelagem-dainformacao-da-construcao/>. Acesso em: 02 jun. 2018.

7ํ Seminário BIM - Modelagem da Informação da Construção. 2016. Disponível em: <http://www.sindusconsp.com.br/acontece/7o-seminario-bimmodelagem-da-informacao-da-construcao/>. Acesso em: 02 ago. 2017.

8 Seminário Internacional BIM terá como tema central inovação e a implantação da ferramenta. 2017. Disponível em:

$<$ https://www.sindusconsp.com.br/8o-seminario-internacional-bim-tera-como-temacentral-inovacao-e-a-implantacao-de-bim/>. Acesso em: 13 jul. 2018.

SINDUSCONJP. Tecnologia BIM começa a expandir em construções escolares. 2016. Disponível em:

<http://www.sindusconjp.com.br/comunicacao/2016/07/05/416293-tecnologia-bimcomeca-a-expandir-em-construcoes-escolares. Acesso em: 28 jul. 2018.

SILVA, E. C.; GIL, A. C. INOVAÇÃO E GESTÃO DE PROJETOS: OS "FINS" JUSTIFICAM OS "MEIOS". Revista de Gestão e Projetos - GeP, São Paulo, v. 4, n. 1, p 138-164, jan./abr. 2013. Disponível em:

<http://www.revistagep.org/ojs/index.php/gep/article/view/75>. Acesso em: 12 mar. 2019

SILVA, E. L.; MENEZES, E. M. Metodologia da Pesquisa e Elaboração de Dissertação. 4. ed. Florianópolis: UFSC, 2005. 138 p. CDU: 001.8

CAVALCANTI, L. O. A Implantação do BIM e a Melhoria do Processo de Projeto na CPTM. Monografia (Especialização em Gestão de Projetos na Construção). Escola Politécnica da Universidade de São Paulo. 103 p. 2018.

SMITH, Peter. BIM \& the 5D Project Cost Manager. In: IPMA-INTERNATIONAL PROJECT MANAGEMENT ASSOCIATION WORLD CONGRESS, 27. 2013. Dubrovnik, Croácia: ElsevierLtd, 2014. 966 p. p. 475 - 484. Disponível em: $<$ https://www.researchgate.net/publication/275245640_BIM_the_5D_Project_Cost _Manager>. Acesso em: 15 jul. 2018

SOUZA, V. P.; NETO, A. I. Sistemas de Informação e Metodologias de Implantação. In: XXVII ENCONTRO NACIONAL DE ENGENHARIA DE PRODUÇÃO - ENEGEP. Foz do Iguaçu, 2007. Disponível em: < http://www.abepro.org.br/biblioteca/enegep2007_tr570426_9608.pdf>. Acesso em: 26 jul. 2018.

SUCCAR, B. Building information modelling framework: A research and delivery foundation for industry stakeholders. Automation in Construction, v. 18, p. 357375. 2009. Disponível em:

<https://edisciplinas.usp.br/pluginfile.php/2942066/mod_resource/content/1/2009Building_information_modelling_framework_A_research_and_delivery_foundation for_industry_stakeholders.pdf\%20\%20\%281\%29.pdf>. Acesso em: 28 mar. 2019. 
SUCCAR, B. The Five Components of BIM Performance Measurement. In: 2010

CIB World Congress. Reino Unido: Salford, 2010b. Disponível em:

$<$ https://www.researchgate.net/publication/215722822_The_Five_Components_of_ BIM_Performance_Measurement?enrichld=rgreq-

4e8be2f761889915101be9acdb6a0eb1-

XXX\&enrichSource=Y292ZXJQYWdIOzIxNTcyMjgyMjtBUzoxMDMyNzMwNzE2ND Q2ODZAMTQwMTYzMzYyNzk2Ng\%3D\%3D\&el=1_x_2\&_esc=publicationCoverP df>. Acesso em: 23 jun. 2018.

SUCCAR, B.; KASSEM, M. Macro-BIM adoption: Conceptual structures. Journal Automation in Construction. 2015. Disponível em:

$<$ https://tees.openrepository.com/tees/handle/10149/593083>. Acesso em: 21 mar. 2018.

SUCCAR, B.; KASSEM, M. Building Information Modelling: Point of Adoption. CIB World Congress. Tampere, Finlândia. Junho, 2016. Disponível em:

$<$ https://www.researchgate.net/publication/301815129_Building_Information_Mode lling_Point_of_Adoption>. Acesso em: 19 mar. 2018.

SUZUKI, R. T.; SANTOS, E. T. Planejamento 4D no Brasil: levantamento orientado à percepção de resultados pelos diversos "stakeholders" da construção. In: ENCONTRO BRASILEIRO DE TECNOLOGIA DE INFORMAÇÃO E COMUNICAÇÃO NA CONSTRUÇÃO, 7, 2015, Recife. Anais... Porto Alegre: ANTAC, 2015.

GSA - U. S. General Services Administration. National 3D-4D-BIM Program. 2017.

Disponível em: <https://www.gsa.gov/real-estate/design-construction/3d4dbuilding-information-modeling >. Acesso em: 27 jul. 2018.

UK Government. Government Construction Strategy. 2011. Disponível em: $<$ https://assets.publishing.service.gov.uk/government/uploads/system/uploads/atta chment_data/file/61152/Government-Construction-Strategy_0.pdf>. Acesso em: 23 abr. 2019.

UK Government. Government Construction Strategy. 2016. Disponível em: < https://assets.publishing.service.gov.uk/government/uploads/system/uploads/attac hment_data/file/510354/Government_Construction_Strategy_2016-20.pdf>. Acesso em: 23 abr. 2019.

YIN, R. K. Estudo de Caso: Planejamento e Métodos. 2. ed. Porto Alegre: Bookman, 2001. 205 p. ISBN: 85-7307-852-9. Disponível em: $<$ https://saudeglobaldotorg1.files.wordpress.com/2014/02/yinmetodologia_da_pesquisa_estudo_de_caso_yin.pdf >. Acesso em: 18 mar. 2018.

YIN, R. K. Estudo de Caso: Planejamento e Métodos. 5. ed. Porto Alegre: Bookmand Editora Ltda.: 2015. 290 p. ISBN: 978-1-452-24256-9. Disponível em: $<$ https://books.google.com.br/books?hl=pt$B R \& \mid r=\& i d=E t O y B Q A A Q B A J \& o i=f n d \& p g=P R 1 \& d q=e s t u d o+d e+c a s o \& o t s=-$ 
k7fnpwZvz\&sig=P9sJz7MSf7c-6qlh_NR7G2q9k8I\#v=onepage\&q\&f=false $>$.

Acesso em: 01 jun. 2018,

ZANELLA, L. C. H. Metodologia de Pesquisa. Universidade Federal de Santa

Catarina. 2. ed. Florianópolis: Departamento de Ciências da Administração/UFSC, 2011. 134 p. ISBN: 978-85-7988-111-3 


\title{
APÊNDICES
}

\section{Apêndice A - Artigo ENTAC}

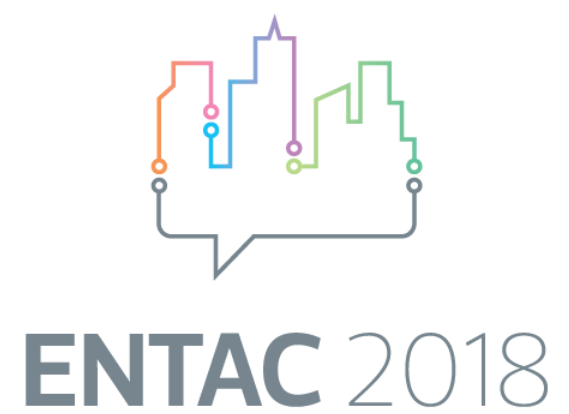

\section{ENCONTRO NACIONAL DE TECNOLOGIA DO AMBIENTE CONSTRUÍDO}

\section{OS DESAFIOS E OS ESFORÇOS DA CADEIA PRODUTIVA DA CONSTRUÇÃO CIVIL PARA A ADOÇÃO DO BIM'}

FREITAS, R. C. F., Universidade de São Paulo, e-mail: raissacffreitas@usp.br; MELHADO, S. B., Universidade de São Paulo, e-mail: silvio.melhado@usp.br; CARDOSO, F. F., Universidade de São Paulo, e-mail: francisco.cardoso@poli.usp.br

\begin{abstract}
It is widely known that the Construction Sector production chain is fragmented and, consequently, has an increasingly need to enhance competitiveness through technological advancements. This is even more important in Brazil, since this production chain's productivity is inferior when compared to others from the same country and also inferior when compared to the same production chain from other countries. BIM methodology is acknowledged by several authors as the key to achieve a better product, since it can bring many benefits for all the agents in this production chain. Moreover, there are also numerous barriers encountered during BIM adoption and usage, many of them are covered in this article. This paper also analyses the efforts for BIM diffusion throughout the country in sectorial and governmental levels.
\end{abstract}

Keywords: ENTAC2018, BIM, BIM barriers, Construction Sector

\section{INTRODUÇÃO}

O setor da Construção Civil tem uma cadeia produtiva muito ampla, onde pode ser estimado em 12,5 milhões o número de profissionais atuantes no setor, sendo que isso representa $13,7 \%$ da população ocupada do país e apenas 6,2 milhões desses profissionais atuam com carteira assinada $(13,4 \%$ da força de trabalho no país), conforme Gráfico 1.

\footnotetext{
1 FREITAS, R. C. F., MELHADO, S. B., CARDOSO, F. F. Os desafios e os esforços da cadeia produtiva da construção civil para a adoção do BIM. In: ENCONTRO NACIONAL DE TECNOLOGIA DO AMBIENTE CONSTRUÍDO, 18., 2018, São Paulo. Anais... Porto Alegre: ANTAC, 2018.
} 
Gráfico 1 - Profissionais atuantes na Construção Civil total e com carteira assinada

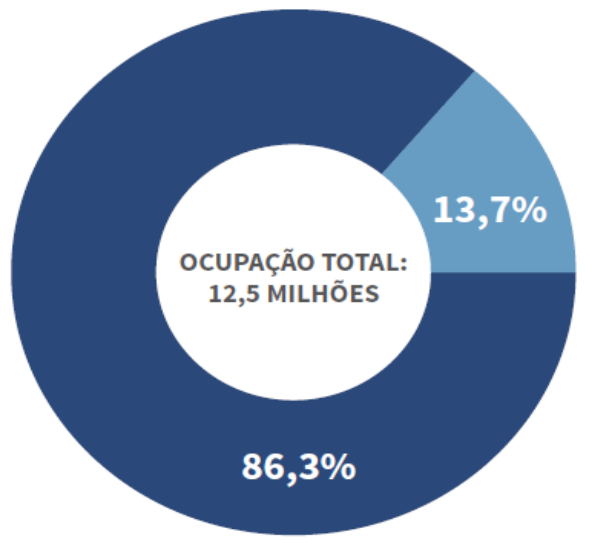

Cadeia produtiva da construção

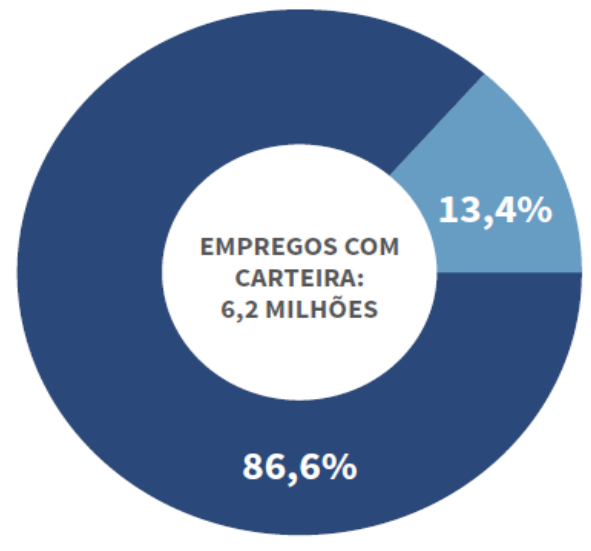

Demais cadeias produtivas

Fonte: FIESP (2016)

De acordo com CBIC (2017), o setor da Construção Civil representa aproximadamente $10 \%$ do PIB brasileiro, o que demonstra sua grande relevância para a economia brasileira e, portanto, a importância da melhoria dos seus processos e ferramentas.

Além disso, esse setor possui profissionais presentes em todo o processo: empresas de materiais, mineração, sistemas industrializados, maquinas e equipamentos, comercio, projeto, construção, cessão de crédito, entre outros, conforme Figura 1.

Figura 1 - Cadeia Produtiva da Construção Civil

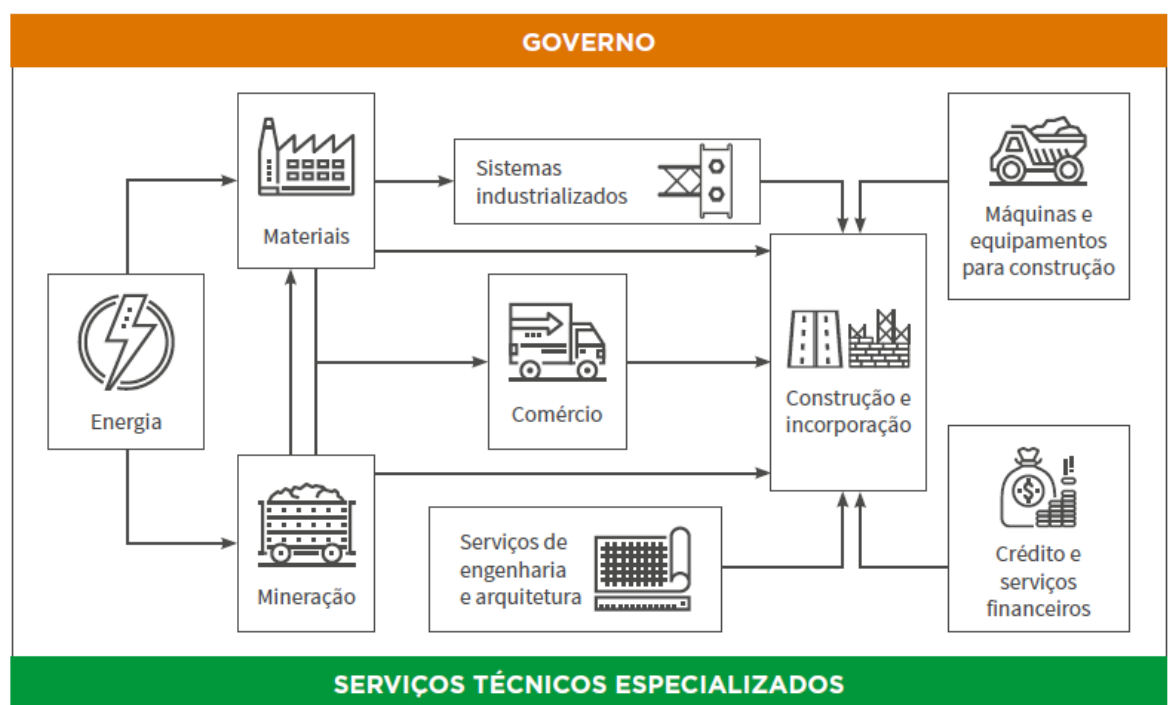

Fonte: FIESP (2016) 
Devido ao tamanho do setor e o elevado número de empresas e profissionais atuantes nele, o aumento da capacidade competitiva é essencial para as empresas que querem se manter no mercado, principalmente no momento de crise econômica que estamos vivenciando no país. A competitividade é crescente em todos os ramos empresariais, portanto para sobreviver é necessário inovar por meio de instrumentos e técnicas (MELHADO E OLIVEIRA, 2006).

Para Cardoso (2005), o desenvolvimento organizacional e tecnológico da cadeia produtiva da Construção Civil são fatores essenciais para aumentar a competitividade do setor. Além disso, de acordo com o MCT (2000), as empresas do setor dependem de alguns fatores para aumentar sua competitividade, dentre eles: a eficiência produtiva, o desenvolvimento do projeto, a tecnologia aplicada nos processos e a capacidade de retroalimentar esses processos.

A grande importância da cadeia produtiva da construção civil para a economia brasileira revela a necessidade crescente em inovação. Diante disso, O Building Information Modeling - BIM representa uma grande oportunidade para as empresas da cadeia produtiva brasileira aumentarem sua eficiência através de processos mais concisos e ferramentas inovadoras. O BIM é definido por Mordue, Swaddle e Philp (2016) como o processo de combinar informações e tecnologia para criar a representação digital de um projeto que integre dados de diferentes fontes e envolvidos, em paralelo com o projeto durante todo o seu ciclo de vida, incluindo design, construção e informações operacionais. Portanto, trata-se de uma inovação eficiente para os processos e para a tecnologia da cadeia produtiva do setor. Entretanto, os agentes ainda encontram muitos desafios durante os processos de implantação, utilização e controle com o BIM.

De acordo com Abaurre, Manzione e Melhado (2011), apesar do BIM representar um novo patamar, há a necessidade de resolver problemas intrínsecos ao processo do projeto para que os mesmos desafios já enfrentados anteriormente não impeçam a utilização plena do BIM. Além desses, existem uma série de novos desafios que surgem com a mudança de trabalho proposta por essa metodologia, como por exemplo, o planejamento minucioso das atividades e a complexidade das trocas de informação e dos novos processos. Esse artigo identifica e analisa os obstáculos enfrentados por esses agentes relacionados à cinco fatores principais: tecnologia, profissionais, organizações, comunicação e gestão, e processos; e explora também as oportunidades e os esforços da cadeia produtiva. 


\section{METODOLOGIA}

Para o desenvolvimento desse trabalho foi desenvolvida uma ampla revisão da literatura, por meio da metodologia de pesquisa bibliográfica com o objetivo de explorar o que já foi pesquisado e relatado sobre o tema discutido nesse artigo. Essa metodologia foi escolhida devido à amplitude do tema, para poder resumir os resultados obtidos até o momento e poder relacioná-los.

A revisão sistemática da literatura foi desenvolvida a fim de identificar e analisar quais são as dificuldades, as necessidades, a importância e as oportunidades relacionadas à adoção e uso do BIM pelos agentes da cadeia produtiva da Construção Civil. Ainda foram pesquisadas as iniciativas setoriais e governamentais realizadas até 0 momento para fomentar essa metodologia.

Segundo Fonseca (2002), a pesquisa bibliográfica é uma metodologia que traz o conhecimento do que já foi constatado anteriormente em pesquisas diversas em relação ao tema abordado e pode servir como único recurso para as pesquisas cientificas que buscam reunir as informações sobre o problema que está sendo tratado.

\section{O BIM E A CADEIA PRODUTIVA DA CONSTRUÇÃO CIVIL}

De acordo com o estudo do SINDUSCONSP (2016b), a produtividade do setor da construção no Brasil é 32,5\% inferior à média da economia do país e representa apenas $30,5 \%$ da produtividade média do mesmo setor nos outros países. De acordo com os estudos de Ferreira e Zancul (2016), a necessidade em aumentar a produtividade do setor da construção civil é urgente devido às diversas questões como o aumento dos custos, as perdas de prazos constantes, impactos na rentabilidade, o aumento da complexidade dos negócios e a carência de mão de obra especializada.

De acordo com Eastman et al. (2014), a cadeia da construção mundialmente tem identificado essa necessidade por melhorias e aumento da produtividade, os esforços para inovar estão sendo desenvolvidos há mais de 20 anos e atualmente a modelagem paramétrica 3D está sendo a aposta para aumentar a eficiência das atividades do setor. Para o autor, com o BIM é possível construir digitalmente um modelo do empreendimento que contenha os dados essenciais para a construção do mesmo, dando suporte a todo o ciclo de vida.

Para Abdelmohsen (2012), o BIM resulta em um o processo onde todos os participantes, as práticas, os sistemas e as estruturas de negócios conversam para maximizar a eficiência. A metodologia BIM pode agregar qualidade ao produto final da cadeia produtiva da construção civil a partir dos seus diversos usos possíveis em cada etapa do processo, conforme Figura 2. 
Figura 2 - Usos do BIM por etapas

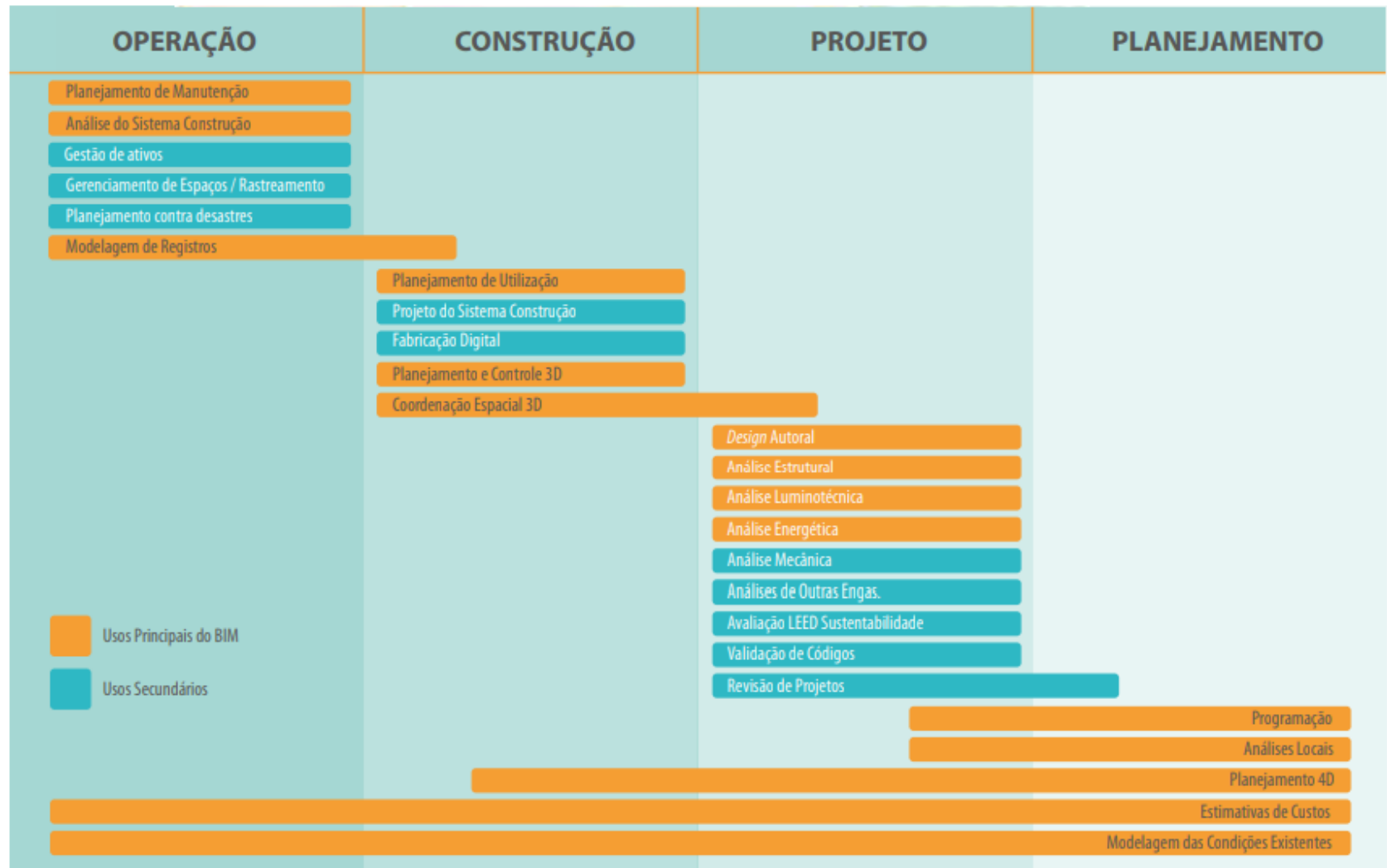

Fonte: CBIC (2016)

O BIM, apesar de trazer benefícios evidentes para os agentes ligados às fases de concepção, projeto e construção, também apresenta uma série de oportunidades de melhorias nos processos dos outros agentes da cadeia, conforme os exemplos ilustrados no Quadro 1 abaixo: 
Quadro 1 - Oportunidades do BIM

\begin{tabular}{|c|c|c|c|}
\hline TIPO DE EMPRESA & \multicolumn{3}{|c|}{ POSSIBIUDADES DE USO DO BIM } \\
\hline $\begin{array}{c}\text { Empresas de gerenciamento } \\
\text { de propriedades }\end{array}$ & $\begin{array}{c}\text { Utilização do modelo para } \\
\text { gerenciamento de facilities e } \\
\text { operação (7D) focado na gestão } \\
\text { dos ativos }\end{array}$ & $\begin{array}{l}\text { Utilização do 7D para o } \\
\text { planejamento das } \\
\text { manutenções }{ }^{2}\end{array}$ & \\
\hline $\begin{array}{c}\text { Empresas de gerenciamento } \\
\text { de projetos e obras }\end{array}$ & Planejamento dos prazos 3 & Logística de canteiro 3 & Diminuição de retrabalho e custos ${ }^{3}$ \\
\hline $\begin{array}{l}\text { Profissionais autônomose } \\
\text { empresas orçamentista }\end{array}$ & $\begin{array}{l}\text { Planejamento dos custos com a } \\
\text { extração de quantitativos }\end{array}$ & & \\
\hline $\begin{array}{l}\text { Empresas de reformas, } \\
\text { restauração e retrofit }\end{array}$ & $\begin{array}{c}\text { Modelar o as-built da construção } \\
\text { para visualizar melhor as } \\
\text { alterações }\end{array}$ & $\begin{array}{c}\text { Utilizar o modelo 3D para planejar } \\
\text { as mudanças, os custos e } 0 \\
\text { tempo }\end{array}$ & $\begin{array}{l}\text { Gerir as informações sobre os } \\
\text { materiais da construção original* }\end{array}$ \\
\hline Empresas de demolição & $\begin{array}{l}\text { Utilização para gerenciamento } \\
\text { dos riscos e emos }\end{array}$ & $\begin{array}{l}\text { Diminuição de custos de } \\
\text { demolição* }\end{array}$ & $\begin{array}{l}\text { Planejamento do sequenciamento } \\
\text { da demolição* }\end{array}$ \\
\hline $\begin{array}{c}\text { Empresas de sistemas } \\
\text { industrializados, como as de } \\
\text { pré-fabricados }\end{array}$ & $\begin{array}{l}\text { Utilizar as ferramentas BIM para a } \\
\text { compreensão detalhada das } \\
\text { peças a serem produzidas }\end{array}$ & $\begin{array}{l}\text { Maior entendimento das } \\
\text { conexões que elas terão com } \\
\text { outras partes da construçãos }\end{array}$ & $\begin{array}{l}\text { Treinamento de sua equipe técnica } \\
\text { de montagems }\end{array}$ \\
\hline $\begin{array}{l}\text { Bancos que concedem } \\
\text { recursos às } \\
\text { incorporadoras/construtoras }\end{array}$ & $\begin{array}{c}\text { Planejamento 5D ajuda na } \\
\text { automatização das etapas de } \\
\text { análise das obras que pleiteiam } \\
\text { recursos' }\end{array}$ & $\begin{array}{c}\text { Planejamento } 4 \mathrm{D} \text { e } 5 \mathrm{D} \text { ajudam na } \\
\text { automatização das etapas de } \\
\text { acompanhamento das obras e } \\
\text { liberação de recursos }{ }^{1}\end{array}$ & \\
\hline \multicolumn{4}{|l|}{ "'(FERRARI, 2016) } \\
\hline \multicolumn{4}{|l|}{$\begin{array}{l}\text { "(HARDIN e MCCOOL, 2015) } \\
4(\text { SCHULTMANN, STENGEL e VD }\end{array}$} \\
\hline
\end{tabular}

Fonte: os autores

Os benefícios que o BIM traz para a cadeia produtiva da construção estão cada vez mais evidentes mundialmente. A McGraw Hill Construction (2014) relata que mundialmente $75 \%$ dos agentes reportaram um positivo retorno no investimento utilizando essa metodologia em seus processos, sendo que no Brasil esse número sobe para $85 \%$ (sendo $36 \%$ retorno muito positivo, $49 \%$ moderado e $15 \%$ sem retorno ou negativo). Ainda nas pesquisas, os agentes relataram que as maiores oportunidades que a metodologia traz é a redução dos erros e omissões durantes os processos de projeto e construção, a colaboração entre os agentes, a melhoria da imagem da empresa no mercado e a diminuição dos retrabalhos.

\section{OS DESAFIOS DOS AGENTES DO SETOR PARA A ADOÇÃO DO BIM}

As vantagens da metodologia BIM e de suas ferramentas são inúmeras, porém muitos agentes ainda encontram desafios para sua utilização. Essas dificuldades ocorrem por ser um tema recente mundialmente e principalmente nacionalmente. Por esse motivo, de acordo com Hergunsel (2011) a utilização dessa metodologia muda a forma de trabalho e, assim, diversas perguntas devem ser respondidas antes de se adotar o BIM em uma empresa, como por exemplo: qual o propósito de se utilizar o BIM? Quais informações serão relevantes para o modelo possuir valor para cada um dos envolvidos? Quem será o responsável por desenvolver, manter e atualizar o 
modelo? Os envolvidos possuem conhecimento suficiente para trabalhar em BIM? Os modelos terão interoperabilidade? Como eles serão compartilhados?

A partir da revisão bibliográfica, essas dificuldades foram identificadas e divididas em cinco fatores relacionados à tecnologia, profissionais, organizações, comunicação e gestão, e processos, conforme ilustrado no Quadro 1 abaixo:

Quadro 2 - Desafios para a adoção e uso do BIM

\begin{tabular}{|c|c|c|c|c|}
\hline Tecnologia & Profissionais & Organizações & Comunicação e Gestão & Processos \\
\hline $\begin{array}{l}\text { Interoperabilidade: } \\
\text { Necessário para evitar a } \\
\text { perda das informações } \\
\text { dos investimentos } \\
\text { criativos singulares dos } \\
\text { componentes da equipe' }\end{array}$ & $\begin{array}{c}\text { Dificuldade de aprendizadoe } \\
\text { rejeição dos profissionais a } \\
\text { mudança, pois todos os processos } \\
\text { de mudanças dentro das } \\
\text { empresas resultam naturalmente } \\
\text { na resistência dos profissionais } \\
\text { gerada pelas incertezas e medo } \\
\text { do desconhecido² }\end{array}$ & $\begin{array}{l}\text { Falta de uso e interesse: } \\
\text { enquanto na América do Norte } \\
\text { as empresas já utilizam o BIM há } \\
8,5 \text { anos, na América do Sul a } \\
\text { média é de } 3,4 \text { anos apenas }{ }^{3}\end{array}$ & $\begin{array}{l}\text { Má comunicação entre as equipes } \\
\text { e falta de trabalho colaborativo? }\end{array}$ & $\begin{array}{l}\text { Necessidade de } \\
\text { reestruturação dos } \\
\text { processos da cadeia } \\
\text { produtiva em geral? }\end{array}$ \\
\hline $\begin{array}{l}\text { Baixa adaptabilidade à } \\
\text { realidade brasileira: } \\
\text { deficiência de conteúdo } \\
\text { especifico em } 3 \mathrm{D} \text { para } \\
\text { componentes da } \\
\text { construção nacional }\end{array}$ & $\begin{array}{l}\text { Falta de mão de obra } \\
\text { qualificada, de contratação de } \\
\text { profissionais especializadose } \\
\text { treinamento }\end{array}$ & $\begin{array}{l}\text { Falta de entendimento da } \\
\text { metodologia: as empresas } \\
\text { acabam investindo na } \\
\text { implantação de novas } \\
\text { tecnologias sem entender as } \\
\text { mudanças que trarão para o } \\
\text { processo de trabalho: } 9\end{array}$ & $\begin{array}{c}\text { Informalidade das relações sociais } \\
\text { entre profissionaist }\end{array}$ & $\begin{array}{l}\text { Mudança do processo de } \\
\text { concepção, projeto e } \\
\text { comunicação* }\end{array}$ \\
\hline $\begin{array}{l}\text { Complexidade dos } \\
\text { softwares: as ferramentas } \\
\text { são diversificadas e sua } \\
\text { compreensão exige } \\
\text { treinamentos e } \\
\text { dedicação de longo } \\
\text { prazo }\end{array}$ & $\begin{array}{c}\text { Falta de incentivo e motivação } \\
\text { ao aprendizado e ao uso }\end{array}$ & $\begin{array}{l}\text { Necessidade de mudança } \\
\text { cultural dentro da empresa" }\end{array}$ & $\begin{array}{l}\text { Falta de normas, boas práticas e } \\
\text { guias nacionais que regularizem e } \\
\text { ensinem o melhor caminho para o } \\
\text { desenvolvimento através do BIM. A } \\
\text { primeira norma BIM brasileira (ABNT } \\
\text { NBR } 15965 \text { ) teve as primeiras } \\
\text { publicaçóes apenas em } 2011^{6}\end{array}$ & $\begin{array}{c}\text { Redefinição do produto } \\
\text { final a partir da mudança } \\
\text { dos processos }\end{array}$ \\
\hline \multirow[t]{3}{*}{$\begin{array}{c}\text { Elevado custo de } \\
\text { implantação devido ao } \\
\text { valor de cada licença } \\
\text { dos softwares, } \\
\text { principaimente por não } \\
\text { haver uma exigência de } \\
\text { utilização do mercado. }\end{array}$} & \begin{tabular}{|l} 
Resistência à mudança da forma \\
de trabalho, ao planejamento, \\
ao uso de novas ferramentas
\end{tabular} & $\begin{array}{c}\text { Uso superficial: tendência de } \\
\text { uso único do BIM pelas } \\
\text { empresas como tecnologia, o } \\
\text { que é chamado de "simples } \\
\text { BIM" (sBim), em vez de empregá. } \\
\text { lo como processo integrado ou } \\
\text { inteligente (iBIM)" }\end{array}$ & & $\begin{array}{l}\text { Processo de projeto } \\
\text { fragmentado }\end{array}$ \\
\hline & & $\begin{array}{c}\text { Falta de organizações } \\
\text { dedicadas à exploração e } \\
\text { estimulação da metodologia } \\
\text { em âmbito nacional, fóruns que } \\
\text { fomentem o desenvolvimento e } \\
\text { o entendimento da } \\
\text { metodologia }\end{array}$ & & $\begin{array}{c}\text { Segmentação da cadeia } \\
\text { produtiva da Construção } \\
\text { Civil. }\end{array}$ \\
\hline & & $\begin{array}{l}\text { Falta de iniciativas de órgãos } \\
\text { do setor público e incentivos } \\
\text { dos governos para fomentar a } \\
\text { utilização do BIM na cadeia } \\
\text { produtiva da Construção Civil. }\end{array}$ & & \\
\hline${ }^{1}$ (RUSCHEL, 2014) & \multicolumn{2}{|c|}{${ }^{4}$ (ABAURRE, MANZIONE e MELHADO, 2011) } & \multicolumn{2}{|l|}{7 (ABDELMOHSEN, 2012) } \\
\hline${ }^{2}$ (FREIRES et al., 2014) & \multirow{2}{*}{\multicolumn{2}{|c|}{$\begin{array}{l}\text { '(AMBROSE, 2006) } \\
\text { "(AMORIM, 2015) }\end{array}$}} & \multirow{2}{*}{\multicolumn{2}{|c|}{$\begin{array}{l}\text { "(AMBROSE E FRY, 2012) } \\
=(\text { ABAURRE et al. 2011) }\end{array}$}} \\
\hline "(JUNG e LEE, 2015) & & & & \\
\hline
\end{tabular}

Fonte: os autores

Esses desafios representam dificuldades não só para as empresas que optam por começar a trabalhar com a metodologia, mas também para o segmento da construção civil que possui uma necessidade evidente por inovação e melhoria da produtividade. 


\section{INICIATIVAS DA CADEIA PRODUTIVA}

A McGraw Hill Construction (2014) relata que o Brasil é um dos países com maior perspectiva de crescimento na adoção do BIM em sua cadeia produtiva nos próximos anos, sendo que na época da pesquisa a maioria dos entrevistados (53\%) estava utilizando a metodologia na produção de empreendimentos comerciais e apenas $12 \%$ para usos governamentais. É possível verificar que dos países pesquisados, o Brasil é o que mais demorou a começar a utilizar a metodologia, sendo que $70 \%$ dos agentes utilizam o BIM há apenas dois anos e desses, quase $60 \%$ possui nível de maturidade entre iniciante e moderado.

Os desafios são variados em toda a cadeia produtiva nacional, porém é possível verificar que já existem diversas discussões, iniciativas e eventos para tratar sobre essas questões e para fomentar a implantação do BIM na cadeia produtiva da Construção Civil brasileira, como por exemplo:

Quadro 3 - Iniciativas para fomentar o BIM no Brasil

\begin{tabular}{|c|c|c|c|}
\hline NORMAS & MOIIVAC̣ÃO & EDUCACIONAL & DISSEMINAÇÃO DO CONHECIMENTO \\
\hline $\begin{array}{c}\text { A NBR } 15965 \text { - Sistema de } \\
\text { classificação da informação da } \\
\text { construção-já teve as partes } 1,2 \text {. } \\
3 \text { e } 7 \text { publicadas, sendo que o } \\
\text { restante está em desenvolvimento.' }\end{array}$ & $\begin{array}{c}\text { O SindusCon-SP criou um Prêmio de } \\
\text { Excelência BIM (2016) com várias } \\
\text { categorias, promovendo as } \\
\text { iniciativas de sucesso no uso de } \\
\text { BIM. }\end{array}$ & $\begin{array}{c}\text { Evento Nacional da CBIC - } \\
\text { Seminário BIM: Oportunidade para } \\
\text { inovar a indústria da construção e } \\
\text { aumentar a transparência das } \\
\text { compras publicas, realizado em } \\
\text { Março de } 2018.5\end{array}$ & $\begin{array}{l}\text { O Comitê de Tecnologia e } \\
\text { Qualidade CTQ do SindusCon-SP } \\
\text { realiza anualmente um seminário } \\
\text { internacional BIM desde } 2010 \text { : }\end{array}$ \\
\hline $\begin{array}{l}\text { Em uma reunião FIESP/DECONCIC } \\
\text { em } 2014 \text {, a ABRAMAT manifestou a } \\
\text { intenção de iniciar um processo } \\
\text { para produção de componentes } \\
\text { digitais para bibliotecas BIM.2 }\end{array}$ & $\begin{array}{c}\text { A CBIC propôs o oferecimento de } \\
\text { subsidio à implantação da } \\
\text { metodologia na cadeia do } \\
\text { segmento? }\end{array}$ & $\begin{array}{c}\text { Em uma reunião FIESP/DECONCIC } \\
\text { em } 2014, \text { o SENAI demonstrou } \\
\text { interesse desenvolver profissionais } \\
\text { focados na metodologia. }{ }^{2}\end{array}$ & $\begin{array}{c}\text { A COMAT junto com o Sinduscon- } \\
\text { AM e a CBIC tem desenvolvido } \\
\text { workshops de implementação do } \\
\text { BIM que estão em sua quarta } \\
\text { edição? }\end{array}$ \\
\hline $\begin{array}{l}\text { Durante o } 88^{\circ} \text { ENIC em } 2016 \text { foi } \\
\text { lançado o primeiro dos cinco guias } \\
\text { que compóem a coletânea } \\
\text { "Implantação BIM para } \\
\text { Construtaras e Incorporadoras". }\end{array}$ & $\begin{array}{c}\text { Em uma reunião FIESP/DECONCIC } \\
\text { em } 2014 \text {, a AsBEA levantou a } \\
\text { questão relativa a necessidade de } \\
\text { incentivos fiscais e desoneração } \\
\text { tributária como estímulo aos } \\
\text { investimentos das empresas que } \\
\text { utilizam o BIM.2. }\end{array}$ & $\begin{array}{c}\text { A COMAT realizou } 10 \text { eventos ao } \\
\text { Iongo de } 2017 \text { de capacitação BIM } \\
\text { da cadeia produtiva da } \\
\text { Construção Civil.s }\end{array}$ & $\begin{array}{c}\text { O Sindara/PR desenvolveu em } \\
201401^{\circ} \text { Seminário Regional } \\
\text { 'Construindo BIM: Desafiose } \\
\text { Perspectivas para implantação no } \\
\text { Brasil'? }\end{array}$ \\
\hline $\begin{array}{c}\text { O MDIC e a ABDI lançaram a } \\
\text { Coletânea Guias BIM ABDI - MDIC } \\
\text { em Novembro de 2017.4 }\end{array}$ & $\begin{array}{c}\text { O Governo Federal desenvolveu o } \\
\text { Plano Brasil Maior onde foi previsto } \\
\text { o uso do BIM.4 }\end{array}$ & $\begin{array}{l}\text { Em Junho de } 2017 \text { o Governo } \\
\text { Federal criou o Comitê Estratégico } \\
\text { de Implementação do Building } \\
\text { Information Modelling - CE-BIM.10 }\end{array}$ & $\begin{array}{c}\text { Existe um projeto do CBIC } \\
\text { chamado "Disseminação do BIM".s }\end{array}$ \\
\hline $\begin{array}{l}\text { Em maio de } 2018 \text { o Governo } \\
\text { Federal lançou uma estratégia que } \\
\text { tem o objetivo de promover a } \\
\text { inovação na indústria do } \\
\text { construção par meio do BIM, } \\
\text { chamada Estratégia } \mathrm{BIM} B R \text { e } \\
\text { instituida pelo Decreto } n^{\circ} 9.377 \text {. }\end{array}$ & & & $\begin{array}{l}\text { A FDE realizou em } 2016 \text { uma } \\
\text { audiência pública sobre a } \\
\text { implantação do BIM em } \\
\text { construções escolares. } \\
\text { (SINDUSCONJP, 2016).3 }\end{array}$ \\
\hline${ }^{1}$ (CATELANI E SANTOS, 2016) & '(BEZERRA, 2017) & (CBIC, 2018) & \\
\hline${ }^{2}$ (KASSEM E AMORIM, 2015) & - (SINDUSCONSP, 2016) & '(MDIC, 2018a) & \\
\hline $\begin{array}{l}\text { "(SINDUSCONJP, 2016) } \\
{ }^{4}(A B D I, 2014)\end{array}$ & ${ }^{\prime}($ BASSO, 2014) & ${ }^{10}$ (MDIC, 2018b) & \\
\hline
\end{tabular}




\section{CONCLUSÕES}

Á partir da análise da pesquisa bibliográfica desenvolvida para este artigo foi possível constatar que a deficiência da produtividade da cadeia produtiva da Construção Civil em relação às outras cadeias nacionais e internacionais revela a necessidade que temos por inovações tecnológicas e mudanças no processo de trabalho. Conforme relatado pelos autores, o BIM é evidentemente a maior oportunidade para alcançarmos melhoria nos processos, no produto final e assim aumentarmos a competitividade do setor, porém como toda mudança apresenta desafios, eles devem ser explorados e solucionados para que a adoção seja eficaz.

Enquanto O BIM oferece soluções para todos os agentes da cadeia produtiva, ele também apresenta uma série de dificuldades que já foram identificadas e estão começando a ser discutidas e tratadas a nível setorial e governamental. Alguns dos desafios identificados nas bibliografias, como a falta de incentivo e motivação, a necessidade de mudança cultural nas empresas do setor, a necessidade de reestruturação dos processos da cadeia produtiva e a falta de iniciativas setoriais para fomentar a metodologia, já estão começando a serem discutidos e tratados nacionalmente, conforme Quadro 3. Além disso, existem diversos países com nível de maturidade superior ao do Brasil, o que representa uma grande oportunidade de aprendizado com os obstáculos superados e os sucessos deles.

Os investimentos recentes da CBIC, do Governo brasileiro e outras entidades confirmam a importância do tema e sugerem que os desafios serão tratados de uma maneira colaborativa por todos da cadeia produtiva para que o objetivo seja atingido. Embora o presente estudo apresente limitações, relatando apenas aquilo já pesquisado e descrito em outras bibliografias, o mesmo atinge o objetivo de relatar a situação atual da adoção, superação de desafios e iniciativas do setor quanto à adoção do BIM. Futuros trabalhos poderão se basear nas informações apresentadas, sugerindo-se que tais informações sejam aprofundadas por meio de estudos de caso.

\section{REFERÊNCIAS}

ABAURRE, M. W.; MANZIONE, L.; MELHADO, S. B. Desafios Para A Implementação Do Processo De Projeto Colaborativo: Análise Do Fator Humano. In: ENCONTRO DE TECNOLOGIA DE INFORMAÇÃO E COMUNICAÇÃO NA CONSTRUÇÃO. 5., 2011. Salvador, Bahia.

Disponível em: <https://www.researchgate.net/publication/309319260_DESAFIOS_PARA_A_IMPLE MENTACAO_DO_PROCESSO_DE_PROJETO_COLABORATIVO_ANALISE_DO_FATOR_H UMANO>. Acesso em: jun, 2018.

ABDELMOHSEN, S. Genres Of Communication Interfaces In Bim-Enabled Architectural Practice. 2012. 11 f. Artigo. Ain Shams University, Egito. Disponível em: 
<http://papers.cumincad.org/data/works/att/ascaad2012_009.content.pdf>. Acesso em: set, 2017.

ABDI - Agência Brasileira de Desenvolvimento Industrial. Sistema inteligente aumenta a produtividade e melhora gestão de obras do Exército. Brasília, 2014. Disponível em: <http://www.abdi.com.br/Paginas/noticia_detalhe.aspx?i=3810>. Acesso em: jun, 2018

AMORIM, K. Sétima Parte Da Primeira Norma Sobre BIM Desenvolvida No Brasil Está Em Consulta Nacional. Portal PINIweb. 2015. Disponível em: <http://construnormas.pini.com.br/engenharia-instalacoes/noticias/setima-parteda-primeira-norma-sobre-bim-desenvolvida-no-brasil-364396-1.aspx>. Acesso em: out, 2017.

AMBROSE, M. Plan Is Dead: To Bim, Or Not To Bim, That Is The Question. In: ASCAAD CONFERENCE - CAAD, INNOVATION AND PRACTICE. 2., 2006. Sharjah, Emirados Árabes Unidos. 442 p. p183 - 189.

AMBROSE, M. A.; FRY, A. M. RE:Thinking Bim In The Design Studio. In: ASCAAD CONFERENCE - CAAD, INNOVATION AND PRACTICE. 6., 2012. Manama, Barém. The Kingdom University. 2012. 302 p. p $71-80$.

BASSO, J. Cadeia produtiva da construção civil é alavancada durante encontro em torno da plataforma BIM. CREA-PR website. 2014. Disponível em: <http://www.creapr.org.br/ws/arquivos/2492>. Acesso em: maio, 2017.

BEZERRA, S. Manaus Sedia O Quarto Workshop De Implementação Do Bim Voltado À Cadeia Produtiva Da Construção. CBIC website. 2017. Disponível em: <http://www.cbic.org.br/sala-de-imprensa/noticia/manaus-sedia-o-quartoworkshop-de-implementacao-do-bim-voltado-a-cadeia-pro> Acesso em: maio, 2017.

CARDOSO, F. F. A Dimensão Organizacional da Construção Civil. In: TIGRE, Paulo Bastos (org.), Setor de Construção Civil: segmento de edificações. Série Estudos Setoriais n. 5. Serviço Nacional de Aprendizagem Industrial. Departamento Nacional / SENAI. DN - Brasília, 2005. pp.71-124.

CBIC - Câmara Brasileira da Indústria da Construção. Implementação do BIM - Parte 2: Implantação do BIM para Construtoras e Incorporadoras. Brasília, 2016. Disponível em: <http://sindusconbc.com.br/wp-content/uploads/2016/10/VOLUME-_2.pdf>. Acesso em: mar, 2018.

Manual básico de indicadores de produtividade na construção civil Volume 1. Brasília, DF: CBIC, 2017. 92 p. Disponivel em: < https://cbic.org.br/wpcontent/uploads/2017/11/Manual_Basico_de_Indicadores_de_Produtividade_na_ Construcao_Civil_2017.pdf>. Acesso em: jun, 2018. 
BIM: Oportunidade para inovar a indústria da construção e aumentar a transparência das compras públicas. Brasília, 2018. Disponivel em: <https://cbic.org.br/inovacao/2018/03/02/bim-oportunidade-para-inovar-aindustria-da-construcao-e-aumentar-a-transparencia-das-compras-publicas-2/>. Acesso em: jun, 2018.

CATELANI, W. S.; SANTOS, E. T. Normas brasileiras sobre BIM. Revista Concreto \& Construções. Out 2016. Edição 84. Pag 54 - 59. Disponível em: <http://ibracon.org.br/Site_revista/Concreto_Construcoes/ebook/edicao84/files/a ssets/basic-html/page54.html>. Acesso em: mar, 2018.

EASTMAN, C. et al. Manual de BIM: Um Guia de Modelagem da Informação da Construção para Arquitetos, Engenheiros, Gerentes, Construtores e Incorporadores. Porto Alegre: Bookman, 2014. 483 p. ISBN: 978-85-8260-1 18-1.

FERRARI, F. A. A introdução da modelagem da informação da construção em um banco público brasileiro. Tese (Mestrado em Engenharia Civil) - UNIVERSIDADE DE SÃO PAULO ESCOLA POLITÉCNICA. São Paulo, p. 119. 2016. Disponível em: <http://www.teses.usp.br/teses/disponiveis/3/3153/tde-23082016-152604/pt-

br.php> Acesso em: jun, 2018.

FERREIRA, A. V.; ZANCUL, E. Estudo sobre produtividade na construção civil: desafios e tendências no Brasil. EY Publicação TM Rio 2016. Disponível em: <https://www.ey.com/Publication/vwLUAssets/EY_Estudo_Produtividade_na_Const rucao_Civil/\$FILE/Estudo_Real_Estate.pdf>. Acesso em: jun, 2018.

FIESP (2016). Investir com responsabilidade. $1^{\circ}$ Congresso Brasileiro da Construção. Construbusiness 2016. Brasil 2022: planejar, construir, crescer. São Paulo: Federação das Indústrias do Estado de São Paulo, 2016. 137p. mais anexos.

FONSECA, J. J. S. Metodologia da pesquisa científica. Fortaleza: UEC, 2002. Apostila. Disponível em: <http://www.ufrgs.br/cursopgdr/downloadsSerie/derad005.pdf>. Acesso em: mar, 2018.

FREIRES, D. A. N. et al. Resistência à Mudança Organizacional: Perspectiva Valorativa e Organizacional. Revista Psico v. 45, n. 4, pp. 513-523. out.-dez. 2014. Porto Alegre. Disponível em: <https://dialnet.unirioja.es/servlet/articulo?codigo=5632996>. Acesso em: mar, 2018.

HARDIN, B. MCCOOL, D. BIM and Construction Management: Proven Tools, Methods, and Workflows. Indianapolis, Indiana, Estados Unidos: John Wiley \& Sons Inc, 2015. 363 p. ISBN: 978-1-118-94276-5. Disponível em: <https://books.google.com.br/books?hl=en\&lr=\&id=1FB_BWAAQBAJ\&oi=fnd\&pg=P $\mathrm{P} 17$ \&dq=bim+construction+management\&ots=F8O230AYaJ\&sig=Rd8Au2utawDfXt mWNo_Rlkyilp8\#v=onepage\&q\&f=false> Acesso em: jun, 2018.

HERGUNSEL, M. F. Benefits of building information modeling for construction managers and BIM based scheduling. Tese (Mestrado em Engenharia Civil) WORCESTER POLYTECHNIC INSTITUTE. Massachusetts, Estados Unidos, p. 89. 2011. 
Disponível em: <https://web.wpi.edu/Pubs/ETD/Available/etd-042011135239/unrestricted/MHergunsel_Thesis_BIM.pdf> Acesso em: jun, 2018.

JUNG, W.; LEE, G. The Status of BIM Adoption on Six Continents. International Journal of Civil, Structural, Construction and Architectural Engineering. Coreia do Sul. v. 9, n. $5,406-410,2015$.

KASSEM, M.; AMORIM, S. R. L. Diálogos Setoriais Para BIM - Building Information Modeling No Brasil E Na União Europeia. Brasília, 2015. 160 f. Disponível em: <http://sectordialogues.org/sites/default/files/acoes/documentos/bim.pdf>.

Acesso em: set, 2017.

MCARTHUR, J. J. A Building Information Management (BIM) Framework and Supporting Case Study for Existing Building Operations, Maintenance and Sustainability. In: INTERNATIONAL CONFERENCE ON SUSTAINABLE DESIGN, ENGINEERING AND CONSTRUCTION. 2015. Chicago, Estados Unidos. Disponível em: <https://www.sciencedirect.com/science/article/pii/S1877705815021050>. Acesso em: jun, 2018.

McGraw Hill Construction. The Bussiness Value of BIM for Construction in Major Global Markets. 2014. SmartMartket Report. Disponível em: < https://www.icnsolutions.nl/pdf/bim_construction.pdf>. Acesso em: jun, 2018.

MCT (2000). Necessidades de ações de desenvolvimento tecnológico na produção da construção civil e da construção habitacional. Texto-base de workshop de mesmo nome. Ministério da Ciência e Tecnologia, Secretaria de Política Tecnológica Empresarial, 31/10/2000. 21 p.

MDIC - Ministério da Indústria, Comércio Exterior e Serviços. Estratégia Nacional de Disseminação do BIM - Estratégia BIM BR. Brasília, 2018a. Disponível em <http://www.mdic.gov.br/index.php/competitividade-industrial/ce-bim>. Acesso em: jun, 2018a.

Comitê Estratégico de Implementação do BIM (CE-BIM). Brasília, 2018b. Disponível em <http://www.mdic.gov.br/index.php/noticias/3317-comiteestrategico-de-implementacao-do-bim-ce-bim>. Acesso em: jun, 2018b.

MELHADO, S.B.; OLIVEIRA, O. J. Como Administrar Empresas de Projeto de Arquitetura e Engenharia Civil. Brasil, São Paulo: Pini Ltda., 2006. 64 p. ISBN: 85-7266167-0.

MORDUE, S.; SWADDLE, P.; PHILP, D. Building Information Modeling for Dummies.

1.ed. Chichester, Reino Unido: John Wiley \& Sons, Ltd. 2016. 333p. ISBN: 978-1-11906007-9.

RUSCHEL, R. C. TO BIM OR NOT TO BIM?. In: Encontro da Associação Nacional de Pesquisa e Pós-graduação em Arquitetura e Urbanismo. 3., 2014. São Paulo. 14 f. 
SCHULTMANN, F.; STENGEL, J.; VOLK, R. Building Information Modeling (BIM) for existing buildings - literature review and future needs. Automation in Construction, v. 43, jul. 2014, 204 p. Disponível em:

<https://pt.scribd.com/document/340599603/BIM-for-Existing-Buildings 1> Acesso em: jun, 2018.

SINDUSCONJP. Tecnologia BIM começa a expandir em construções escolares. 2016.

Disponível em:

<http://www.sindusconjp.com.br/comunicacao/2016/07/05/416293-tecnologiabim-comeca-a-expandir-em-construcoes-escolares>. Acesso em: ago, 2017.

SINDUSCONSP. $7^{\circ}$ Seminário BIM - Modelagem da Informação da Construção. São Paulo, 2016. Disponível em: http://www.sindusconsp.com.br/acontece/7oseminario-bim-modelagem-da-informacao-da-construcao/. Acesso em: ago, 2017.

SINDUSCONSP. Produtividade brasileira na construção ficou abaixo da média mundial na última década. São Paulo, 2016b. Disponível em: <https://www.sindusconsp.com.br/produtividade-brasileira-na-construcao-ficouabaixo-da-media-mundial-na-ultima-decada/>. Acesso em: jun, 2018. 


\title{
Apêndice B - Artigo ENTAC
}

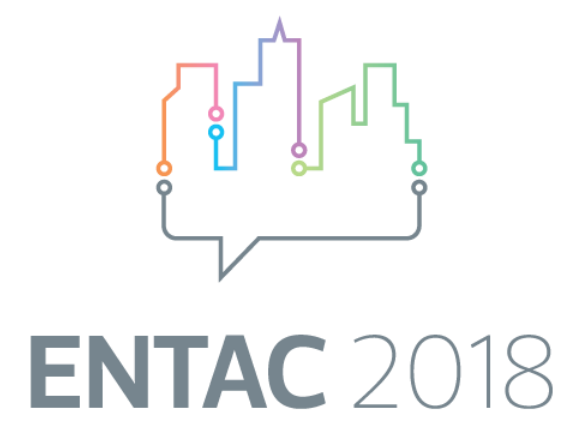

\section{ENCONTRO NACIONAL DE TECNOLOGIA DO AMBIENTE CONSTRUÍDO}

Desafios da Inovação no Ambiente Construído

\section{O PROCESSO DE ADOÇÃO DO BIM EM UMA CONSTRUTORA DE GRANDE PORTE DE SÃO PAULO²}

FREITAS, R. C. F., Universidade de São Paulo, e-mail: raissacffreitas@usp.br; MELHADO, S. B., Universidade de São Paulo, e-mail:

\begin{abstract}
The BIM adoption process is challenging, since there are many approaches to its implementation, and it relies on the company's objectives, strategies and willingness to modify its own working method. Moreover, there are several stages that are crucial for the methodology rollout success and to guarantee that the implementation objectives are met. As well as any other massive processes change, BIM deployment raises concern and resistance on the company's professionals, therefore understanding the meaning of the methodology and how this implementation is going to impact their working process is fundamental for all employees. That being said, the purpose of this article is to report the experience of a large construction company during its BIM adoption process and to analyze the deployment phases, the key issues to achieve the expected goals and the challenges encountered during this process. From the case study it was possible to understand that, despite the different paths to implement BIM in a company, it is essential to focus on the design of the adoption process, the planning of the process change and the employees' cultural preparation.
\end{abstract}

Keywords: ENTAC2018, BIM, BIM adoption, BIM implementation process

\section{INTRODUÇÃO}

O processo de adoção do BIM - Building Information Modeling - é longo e, como toda implantação de uma nova metodologia, é desafiadora para qualquer organização. Isso ocorre porque os objetivos previstos podem não ser atingidos devido à falta de planejamento, de uma estratégia de implantação e de definição dos processos consistentes com o nível de maturidade BIM ideal para aquela empresa, de acordo com Sackey, Tuuli e Dainty (2013). Qualquer processo de mudança dentro das organizações

\footnotetext{
2 FREITAS, R. C. F., MELHADO, S. B. O processo de adoção do BIM em uma construtora de grande porte de São Paulo. In: ENCONTRO NACIONAL DE TECNOLOGIA DO AMBIENTE CONSTRUÍDO, 18. 2018, São Paulo. Anais... Porto Alegre: ANTAC, 2018.
} 
tem, naturalmente, como principal desafio a resistência dos profissionais gerada pelas incertezas e medo do desconhecido (FREIRES et al., 2014).

O BIM é mais do que apenas novos softwares, porém algumas empresas ainda não compreendem isso completamente e acabam frustrando seus profissionais durante o processo de adoção. De acordo com Sackey, Tuuli e Dainty (2013), apenas as empresas que compreendem completamente a inovação proposta são as que realizam todos os esforços necessários de mudança em sua estrutura organizacional, em sua estratégia e em seus processos. De acordo com Kiviniemi (2008), para conseguir alcançar todos os benefícios que o BIM pode trazer, é essencial que as empresas mudem seus processos e sua maneira de trabalho.

O presente estudo relata a experiência de uma construtora de infraestrutura de grande porte durante todo o seu processo de adoção até o presente momento. Esse trabalho tem o objetivo de identificar os melhores caminhos para a adoção do BIM como processo e os desafios encontrados.

\section{REVISÃO DA LITERATURA}

\subsection{BIM}

Ao contrário do que alguns autores afirmam, o BIM é uma atividade humana a ser desenvolvida e que gera transformações no produto final do setor e evoluções no processo de produção, portanto é mais do que apenas softwares e ferramentas (EASTMAN et al., 2014). Succar e Kassem (2016) conceituam que o BIM é um domínio do conhecimento que está em expansão, que fomenta a mudança nos processos e que impacta o produto final, os relacionamentos entre os agentes e os papeis dos profissionais do setor. Para Mordue, Swaddle e Philp (2016) e Eastman et al. (2014), com o BIM é possível construir digitalmente um modelo do empreendimento com todas as informações necessárias do ciclo de vida, centralizando esses dados e permitindo o compartilhamento entre todos os envolvidos conforme Figura 1. 
Figura 1 - O fluxo da informação com o uso do BIM
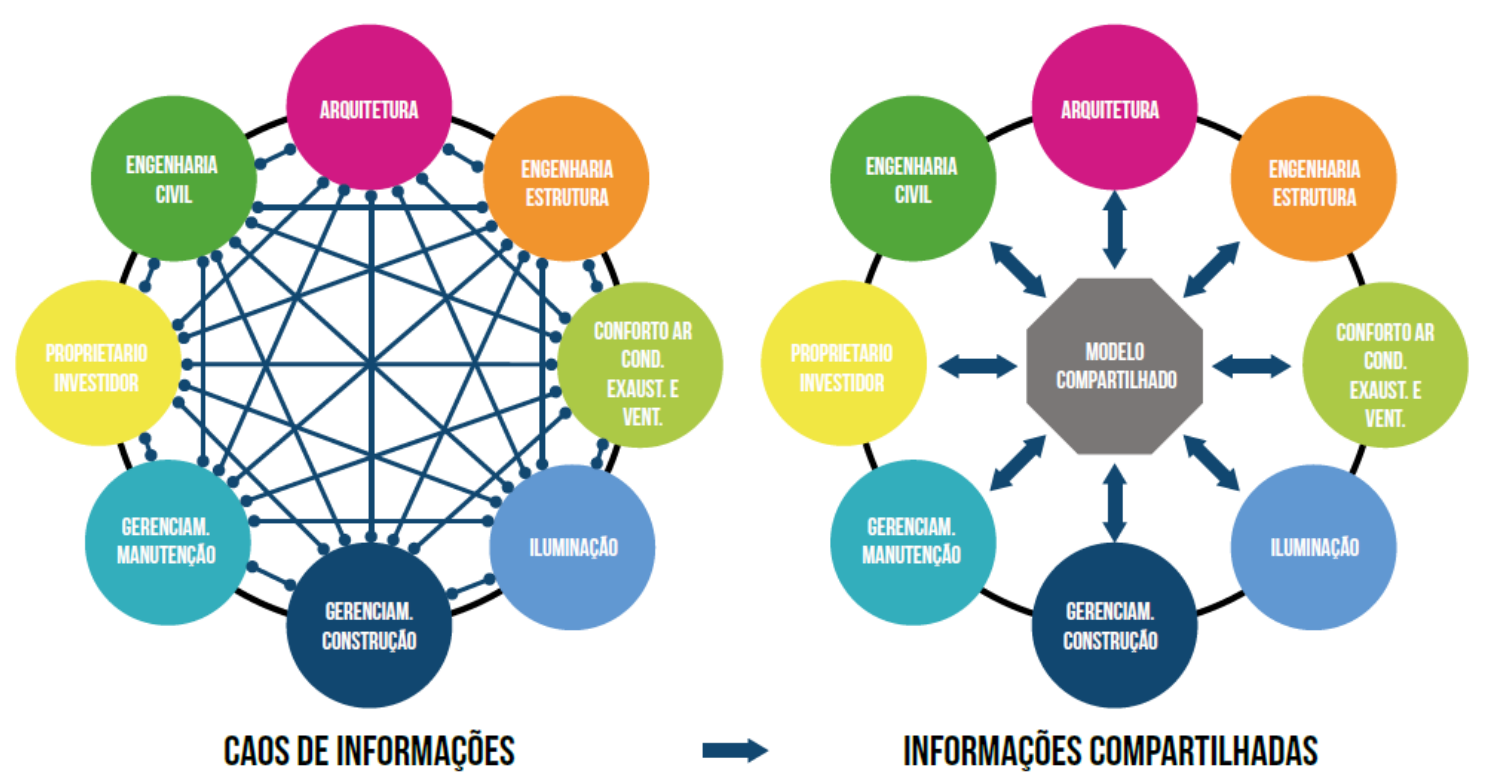

Fonte: CBIC (2016a)

\section{2 processo de adoção do BIM}

A adoção do BIM precisa ser um processo pensado, planejado e estruturado para que os benefícios da adoção sejam realmente alcançados. Para Succar e Kassem (2015), o primeiro passo é a verificação da aptidão da organização para a adoção do BIM, esse momento refere-se ao planejamento e atividades de preparação que devem anteceder a implementação. O segundo passo é a implementação das ferramentas ideais identificadas, do novo processo de trabalho planejado e dos protocolos definidos. Por fim, existe a fase de maturidade, que deve ser uma busca constante pela melhoria dos processos, da qualidade e do produto final.

Para CBIC (2016b), a adoção do BIM ideal é através de um projeto formal de implantação, estruturado e documentado, conforme Figura 2. 
Figura 2 - llustração demonstrando os principais passos para um projeto de implementação BIM

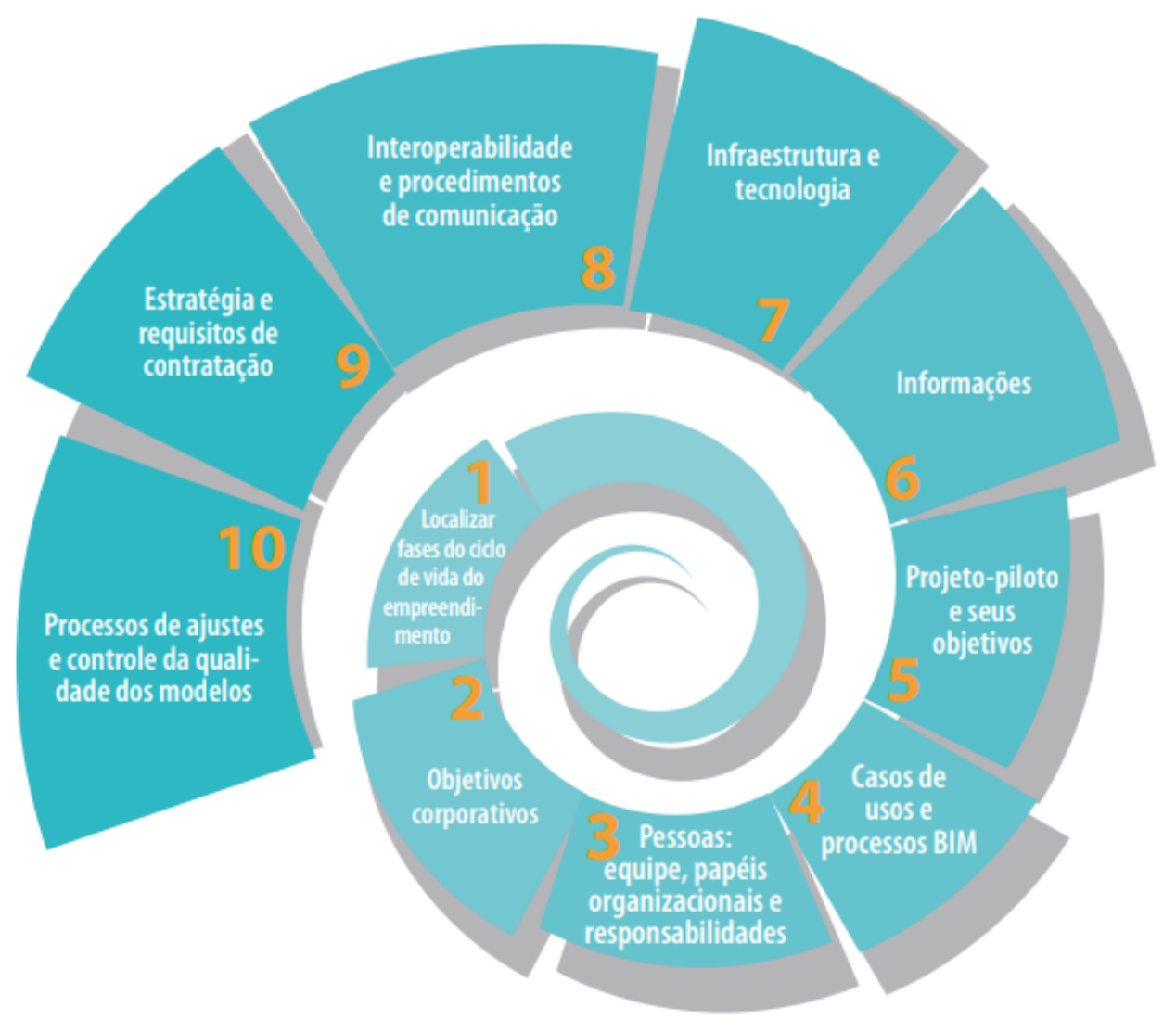

Fonte: CBIC (2016b)

Segundo relatos de Eastman et al. (2014), a adoção do BIM pode ser feita internamente ou gerencialmente. Internamente, a equipe interna deve ser capaz de se adaptar a nova forma de trabalho e deve ter os conhecimentos nivelados em relação a essa metodologia (MANZIONE, 2013), então é necessário definir um mapa para a adoção do BIM, estabelecendo fases para a implantação, treinamentos dos softwares, palestras ou contratação de profissionais com o know-how necessário.

Gerencialmente, a empresa não precisa ter todo o conhecimento das ferramentas, porém precisa ter pontos focais dentro da equipe que saibam a maneira de coordenar os contratados. De acordo com Eastman et al. (2014), a seleção dos contratados deve ser um processo cauteloso, por meio de exigências relacionadas à experiência e conhecimento sobre BIM, definição de critérios de pré-qualificação e entrevistas com os potenciais contratados.

As entregas e os requisitos também devem sofrer alteração. Ainda segundo o autor, para isso é necessária uma definição clara do escopo e do detalhamento da informação que o modelo BIM deverá conter, dos usos para o qual o modelo será utilizado e da estrutura da organização de toda a informação. Os usos do BIM podem ser encontrados na Figura 3. 
Figura 3 - Usos do BIM por etapas

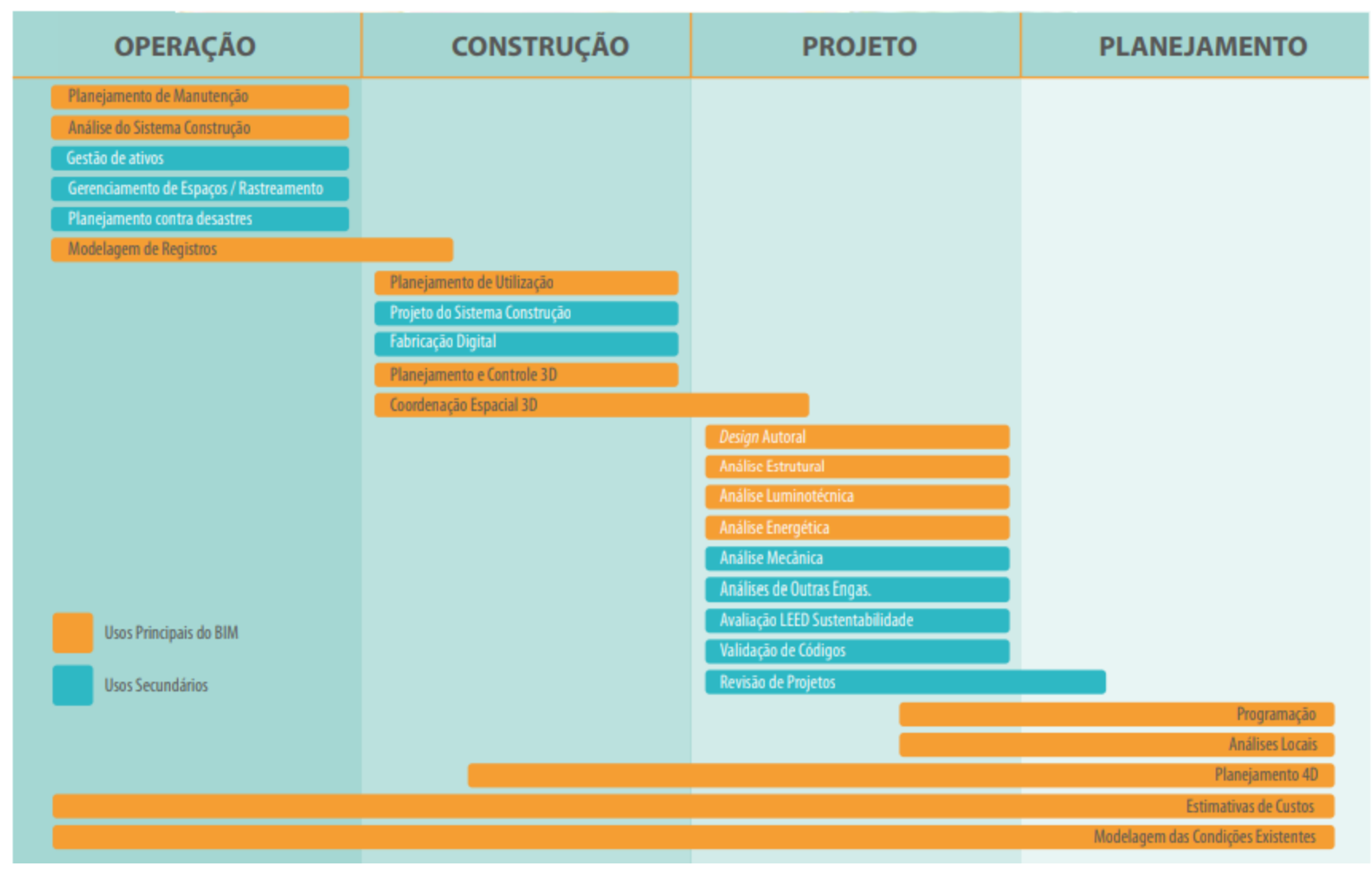

Fonte: CBIC (2016b)

Portanto, é possível concluir que não existe apenas uma maneira de adotar - BIM nas empresas, pois os autores relatam diversas formas de se fazer para que o objetivo seja atingido. De acordo com Succar e Kassem (2015), o grande obstáculo é que as organizações não conseguem diferenciar a compra de softwares da real adoção do BIM.

\section{MÉTODOS DE PESQUISA}

Para entender o processo de implantação do BIM nas empresas de infraestrutura do país, a metodologia adotada para esse trabalho foi a pesquisa descritiva que teve como objeto a pesquisa bibliográfica, seguido de estudos de casos múltiplos e por fim uma análise crítica.

Segundo Fonseca (2002), a pesquisa bibliográfica traz o conhecimento do que já foi pesquisado anteriormente em relação ao tema abordado e auxilia na contextualização do trabalho. Yin (2001) afirma que o estudo de caso é uma técnica que ajuda na compreensão dos fenômenos individuais, organizacionais, sociais e políticos.

Esse trabalho procurou compreender o processo de adoção do BIM a partir das experiências relatadas pelos profissionais da empresa através de entrevistas. A escolha da empresa foi feita a partir da sua relevância no mercado de infraestrutura do estado e do país. A Figura 4 ilustra o fluxo da pesquisa desenvolvida para esse artigo. 
Figura 4 - Delineamento da pesquisa
Pesquisas
Bibliográficas
Análise
Crítica dos
Resultados

$\begin{array}{cccc}0 & 0 & 0 & 0 \\ & \begin{array}{c}\text { Estudo de } \\ \text { Caso }\end{array} & & \text { Conclusões }\end{array}$

Fonte: os autores.

\section{RESULTADOS}

A Empresa entrevistada é uma construtora multinacional com mais de setenta anos de atuação no mercado de infraestrutura e mais de cinquenta mil funcionários. A adoção do BIM nesta empresa iniciou em 2011 e se estende até hoje, sendo que as fases desse processo estão ilustradas no Quadro 1.

Quadro 1 - Os quatro primeiros anos na adoção do BIM

\begin{tabular}{|c|c|c|c|c|}
\hline & 2011 & $2011-2014$ & $2013-2014$ & 2014 \\
\hline MOTIVAÇÃO & $\begin{array}{l}\text { Um diretor visionário que percebia } \\
\text { a necessidade da empresa por } \\
\text { inovação e melhores soluções que } \\
\text { pudessem melhorar o } \\
\text { desempenho e a qualidade do } \\
\text { produto final. }\end{array}$ & $\begin{array}{c}\text { Demandas internas de estudos de } \\
\text { canteiro, demanda referente a } \\
\text { novas contratações e demanda } \\
\text { pelo desenvolvimento do } 4 \mathrm{D} \text { a } \\
\text { partir do contratante das obras } \\
\text { de refinarias. }\end{array}$ & $\begin{array}{l}\text { Dificuldades na obra de uma usina } \\
\text { hidrelétrica que a empresa havia } \\
\text { construído e que durou quase } 10 \\
\text { anos: precariedade dos projetos em } \\
\text { 2D, desperdício de concreto, perda } \\
\text { do prazo contratual, dificuldade na } \\
\text { comunicação entre os envolvidos e } \\
\text { falta de planejamento. }\end{array}$ & $\begin{array}{l}\text { Necessidade de maior } \\
\text { estruturação da área, devido à } \\
\text { importancia que a mesma estava } \\
\text { começando a ganhar na } \\
\text { empresa com essas novas idéias, } \\
\text { soluções e melhorias para o } \\
\text { produto final. }\end{array}$ \\
\hline AÇÃO & $\begin{array}{c}\text { O diretor optou pela contratação } \\
\text { de um profissional do mercado } \\
\text { experiente com a metodologia } \\
\text { BIM para ser gerente da área de } \\
\text { inovação. }\end{array}$ & \begin{tabular}{|} 
Utilização de softwares de \\
modelagem 3D para o \\
desenvolvimento das propostas \\
comerciais e estudos de canteiro. \\
Necessidade da contratação de \\
um profissional para o \\
desenvolvimento 4D, pois os \\
profissionais da área não haviam \\
recebido treinamento desse uso.
\end{tabular} & $\begin{array}{l}\text { Foi criado um projeto interno de } \\
\text { inovação disruptiva que buscou } \\
\text { soluções para diminuir o desperdício } \\
\text { de concreto em suas obras. Para isso } \\
\text { desenvolveu estudos, pesquisas } \\
\text { internacionais, pesquisas de } \\
\text { mercado, pesquisas acadêmicas e } \\
\text { fórum de fornecedores. }\end{array}$ & $\begin{array}{l}\text { Foi contratado um novo } \\
\text { profisional experiente em BIM } \\
\text { para assumir a liderança da área } \\
\text { e a adoção do BIM tomou um } \\
\text { rumo diferente, decidiram levar o } \\
\text { BIM para as obras e transformá-lo } \\
\text { em um processo empresarial. }\end{array}$ \\
\hline RESULTADO & $\begin{array}{c}\text { Nesse momento novas } \\
\text { ferramentas e expertises foram } \\
\text { incorporadas a empresa através } \\
\text { de treinamentos e } \\
\text { especializações em softwares BIM. }\end{array}$ & $\begin{array}{c}\text { Treinamento da equipe interna } \\
\text { referente ao desenvolvimento do } \\
\text { BIM 4D pelo profissional } \\
\text { contratado. }\end{array}$ & $\begin{array}{l}\text { O BIM surgiu como a solução mais } \\
\text { promissora em relação aos } \\
\text { resultados, com a possibilidade não } \\
\text { só de ajudar com o desperdício do } \\
\text { concreto nas obras, mas também } \\
\text { com uma série de outras questões e } \\
\text { dificuldades que a empresa tinha } \\
\text { com obras de grande porte. }\end{array}$ & $\begin{array}{l}\text { Escolha de um projeto-piloto para } \\
\text { a implantação do BIM em uma } \\
\text { obra e contratação de uma } \\
\text { consultoria BIM para a } \\
\text { estruturação do Plano BIM. A } \\
\text { consultoria também fol } \\
\text { responsável por realizar } \\
\text { treinamento para a área e para } \\
\text { a equipe da obra. }\end{array}$ \\
\hline
\end{tabular}

Fonte: Os autores 
O Projeto de Inovação estratégica deu início à adoção do BIM nas obras, começou com a contratação de uma consultoria de implantação que a princípio realizou treinamentos para a equipe dessa área e auxiliou na definição do Projeto-Piloto da implantação. Os Quadros 2, 3 e 4 ilustram o contexto durante a obra e os caminhos que a adoção do BIM tomou pósobra.

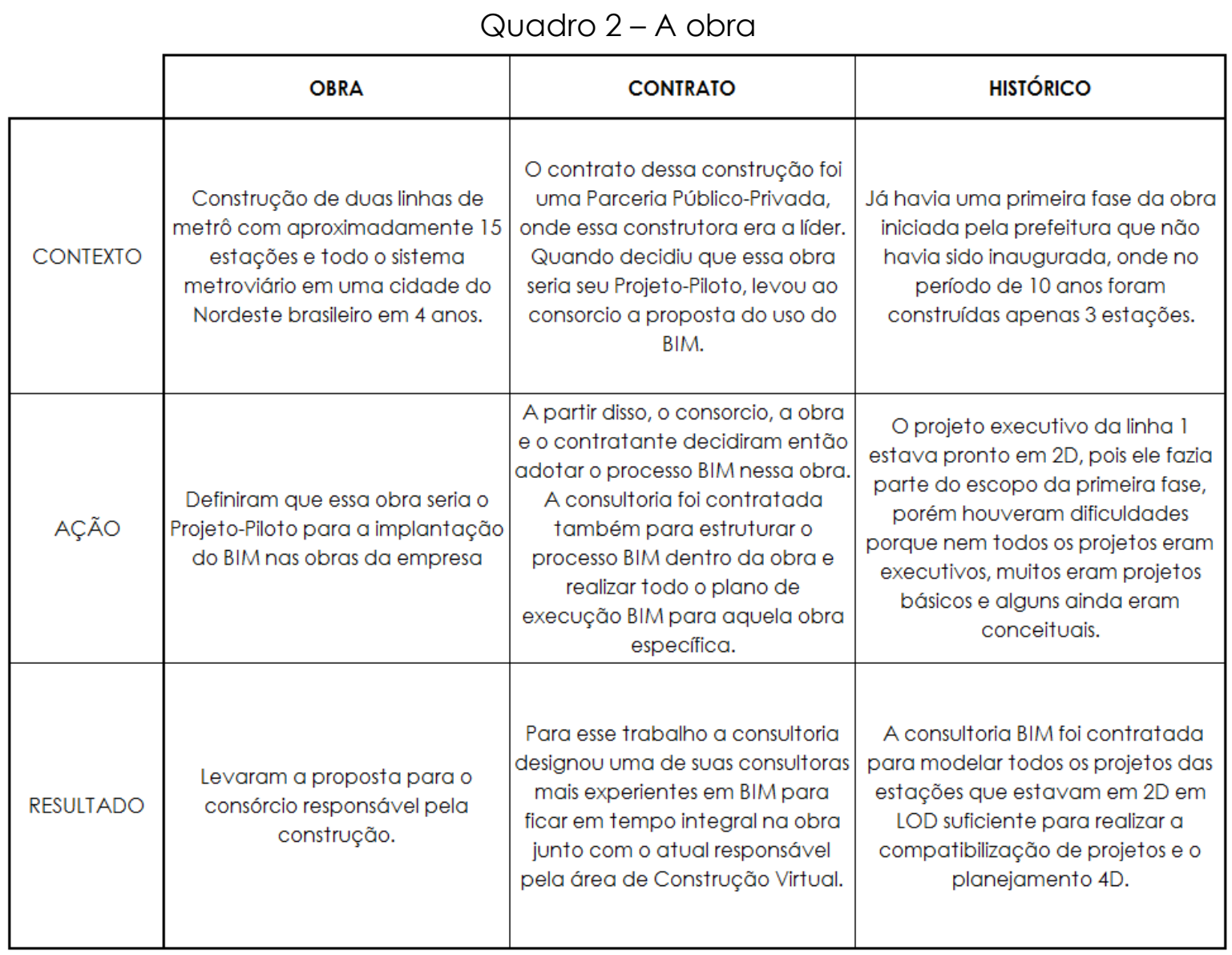

Fonte: os autores. 


\begin{tabular}{|c|c|c|c|}
\hline & PROJETOS & MODELAGEM 3D & PLANEJAMENTO 4D \\
\hline CONTEXTO & $\begin{array}{c}\text { Surgiu um número imenso de } \\
\text { projetos em 2D sendo revisados, } \\
\text { porque eles haviam sido } \\
\text { desenvolvidos para a fase } 1 \text { da } \\
\text { obra que começou em } 2005 \text {, } \\
\text { então estavam completamente } \\
\text { desatualizados em relação as } \\
\text { soluções construtivas. }\end{array}$ & $\begin{array}{c}\text { Necessidade de um grande } \\
\text { esforço inicial de modelagem, pois } \\
\text { todos os projetos estavam em 2D } \\
\text { e havia a necessidade da } \\
\text { compatibilização dos mesmos e } \\
\text { utilização para outros fins como } \\
\text { planejamento, cronograma, } \\
\text { extração de quantitativos e etc. }\end{array}$ & $\begin{array}{l}\text { Visando o desenvolvimento do 4D, a } \\
\text { empresa entendeu que aquele } \\
\text { momento seria ideal para treinar a } \\
\text { equipe da obra para realizar o } \\
\text { planejamento } 4 \mathrm{D} \text {, então contratou } \\
\text { um profissional experiente do } \\
\text { mercado. }\end{array}$ \\
\hline AÇÃO & $\begin{array}{l}\text { As empresas projetistas } \\
\text { contratadas pelo consórcio para } \\
\text { atualizar os projetos 2D não } \\
\text { trabalhavam com o BIM. }\end{array}$ & $\begin{array}{c}\text { Foi feita a modelagem dos } \\
\text { projetos de estrutura, arquitetura, } \\
\text { sistema de drenagem, instalações } \\
\text { subterrâneas das estações e do } \\
\text { complexo de manutenção que } \\
\text { seria uma parte crucial da obra e } \\
\text { teria um prazo muito curto de } \\
\text { execução. }\end{array}$ & $\begin{array}{l}\text { Apesar dos esforços e da } \\
\text { oportunidade, não foi possível } \\
\text { treinar os engenheiros da obra a } \\
\text { usar a ferramenta Sincro, porque a } \\
\text { maioria se recusou em alterar sua } \\
\text { forma de trabalho. }\end{array}$ \\
\hline RESULTADO & $\begin{array}{l}\text { Todas essas novas revisões de } \\
\text { projetos em 2D tiveram que ser } \\
\text { remodeladas em 3D nos modelos } \\
\text { que já haviam sido desenvolvidos } \\
\text { pela consultoria, gerando } \\
\text { retrabalho. }\end{array}$ & $\begin{array}{c}\text { O modelo BIM da obra foi } \\
\text { Utilizado para realizar o } \\
\text { planejamento 4D e também para } \\
\text { compatibilizar os projetos, porque } \\
\text { o projeto executivo estava sendo } \\
\text { desenvolvido em paralelo com a } \\
\text { obra. }\end{array}$ & $\begin{array}{l}\text { Contrataram uma profissional do } \\
\text { mercado experiente na ferramenta. } \\
\text { Os engenheiros da obra } \\
\text { continuaram fazendo seu } \\
\text { planejamento na ferramenta } \\
\text { Primavera, enquanto a profissional } \\
\text { compatibilizava o modelo 3D com o } \\
\text { planejamento do Software } \\
\text { Primavera para gerar o 4D. }\end{array}$ \\
\hline
\end{tabular}

Fonte: os autores.

Quadro 4 - A gestão do processo

\begin{tabular}{|c|c|c|c|}
\hline & GESTÃO E ACOMPANHAMENTO & O PLANO DE EXECUÇÃO BIM & DISSEMINAÇÃO INTERNA DO BIM \\
\hline CONTEXTO & $\begin{array}{l}\text { Em } 2014 \text { e } 2015 \text { o gerente da área } \\
\text { de Construção Virtual ficou em } \\
\text { tempo integral na obra e após } \\
\text { esse período retornou para São } \\
\text { Paulo porque o processo BIM já } \\
\text { estava estruturado e } \\
\text { funcionando na época. }\end{array}$ & $\begin{array}{c}\text { Em 2015, a área começou então } \\
\text { a se estruturar para transformar o } \\
\text { BIM em um processo corporativo } \\
\text { e criaram um Plano de Execução } \\
\text { BIM que pode ser aplicado em } \\
\text { qualquer nova obra da empresa. }\end{array}$ & $\begin{array}{c}\text { Em 2016, a área de Construção } \\
\text { Virtual desenvolveu e apresentou } \\
\text { para todas as gerências da empresa } \\
\text { uma palestra completa sobre o BIM, } \\
\text { seus benefícios, aplicabilidades, } \\
\text { objetivos BIM e responsabilidades da } \\
\text { área. }\end{array}$ \\
\hline AÇÃO & $\begin{array}{c}\text { Em 2016, a gestão da obra foi } \\
\text { modificada e decidiram não } \\
\text { utilizar mais o processo BIM, } \\
\text { portanto todo o trabalho } \\
\text { desenvolvido durante aqueles } \\
\text { dois anos não tiveram conclusão. } \\
\text { A obra foi finalizada } \\
\text { praticamente dentro do prazo } \\
\text { estipulado de } 4 \text { anos. }\end{array}$ & $\begin{array}{c}\text { Ele traz a estrutura genérica que } \\
\text { cada Plano de Execução BIM } \\
\text { deverá conter, como o escopo do } \\
\text { projeto e da obra, a matriz de } \\
\text { responsabilidades dos envolvidos, } \\
\text { os usos específicos para aquele } \\
\text { projeto e os objetivos a serem } \\
\text { atingidos. }\end{array}$ & $\begin{array}{c}\text { Foi definido então que o objetivo da } \\
\text { empresa é o de estabelecer o } \\
\text { processo BIM nas novas } \\
\text { contratações de projetos e } \\
\text { propostas para novas obras. }\end{array}$ \\
\hline RESULTADO & $\begin{array}{c}\text { Apesar da impossibilidade de } \\
\text { extrair resultados, a experiência } \\
\text { que a área adquiriu durante esses } \\
\text { dois anos deram a eles o } \\
\text { conhecimento necessário para } \\
\text { transformar o processo de } \\
\text { trabalho com o BIM na empresa. }\end{array}$ & $\begin{array}{c}\text { Deve ser feita uma Avaliação de } \\
\text { Aplicabilidade no início de cada } \\
\text { proposta nova, identificando as } \\
\text { aplicabilidades do BIM para } \\
\text { aquele projeto e desenvolver o } \\
\text { Plano BIM em conjunto com os } \\
\text { stakeholders. }\end{array}$ & $\begin{array}{c}\text { Previram capacitação dos } \\
\text { profissionais internos em conjunto } \\
\text { com o RH, apoio na contratação de } \\
\text { projetistas, exigências a serem } \\
\text { incluídas no contrato, disseminação } \\
\text { do conhecimento internamente e } \\
\text { maior qualidade do produto final. }\end{array}$ \\
\hline
\end{tabular}

Fonte: os autores. 
A empresa relata que, apesar da apresentação que fizeram para a empresa referente aos benefícios que já estão bastante evidenciados atualmente, ainda assim internamente existe rejeição à mudança em relação à utilização do BIM como um processo corporativo, principalmente nas obras, pois há a necessidade de treinamento dos envolvidos e utilização plena, o que gera dificuldades e custos.

\section{ANÁLISE DOS RESULTADOS}

A partir do estudo de caso, foi possível identificar que o processo de adoção do BIM na empresa iniciou com a contratação de um profissional do mercado, seguido de treinamentos das ferramentas para a equipe interna, conforme Eastman et al. (2014), Manzione (2013) e Succar e Kassem (2015) indicam como essencial para o processo de adoção. Entretanto não foi realizado nenhum planejamento prévio, nem definição das etapas as quais a empresa teria que seguir para efetivamente adotar $\mathrm{O}$ BIM em seus processos, o que ocasionou uma série de contratações e alongamento do processo de adoção na empresa por sete anos.

O projeto-piloto é uma fase muito importante no processo de adoção do BIM, conforme descrito na bibliografia de CBIC (2016b), porém sua escolha foi contrária à orientação do autor, pois a complexidade da obra era alta. O prazo curtíssimo, os projetos em $2 \mathrm{D}$ e a quantidade de revisões, agravou o desenvolvimento com o BIM e impediu a verificação dos benefícios da metodologia e de sua implantação, principalmente porque a obra deixou de utilizar o BIM antes de sua conclusão.

Os profissionais da obra rejeitaram a aprendizagem tanto do processo BIM quanto dos novos softwares, visto que estavam com outras preocupações naquele momento e sem tempo para aprender. Os usos que o BIM teria dentro da empresa foram sendo identificados ao longo do caminho, durante sua utilização desorganizada pelos membros da equipe. Apenas cinco anos após o início da adoção do BIM que esses usos foram definidos e colocados no papel em um Plano BIM da empresa.

A partir disso, é possível perceber que a precipitação da empresa ao implementar as ferramentas, treinar e utilizar tudo ao mesmo tempo, sem planejar os passos para a adoção inicialmente e tempos necessário para o amadurecimento da equipe conforme relatado por Succar e Kassem (2015), e CBIC (2016b), fez com que a adoção do BIM nessa empresa se estendesse até atualmente. Apesar do ocorrido, todas essas experiencias serviram de aprendizado para a empresa desenvolver então o seu Plano BIM e iniciar a real adoção da metodologia na empresa. Fica claro o amadurecimento dos estágios da adoção do BIM na organização, relatado por Succar e Kassem (2015) como a última fase. 


\section{CONCLUSÕES}

A partir dos resultados identificados, é possível concluir que o processo de adoção do BIM deve seguir uma estrutura completa que depende não só do treinamento da equipe e da compra dos handwares e softwares, mas principalmente do planejamento dessa implantação, em concordância com os estudos de Succar e Kassem (2015), CBIC (2016b) e Manzione (2013). A definição clara das etapas e a indicação de um responsável por colocálas em prática e gerenciá-las é essencial para garantir que as mesmas sejam corretamente implementadas e assegurando, assim, uma adoção eficaz.

Entende-se, também, que deve ser desenvolvido um estudo prévio para identificar o Projeto-Piloto ideal, prevendo a complexidade controlada do projeto para que não haja grandes dificuldades no mesmo, tendo em vista as dificuldades inerentes ao processo de adoção de uma nova metodologia.

Ademais, deve-se enfatizar que o interesse da adoção do BIM deve estar em concordância com todas as áreas da empresa, com o propósito de evitar boicote do processo pelos profissionais da própria empresa. Conforme definem os autores Eastman et al., 2014, o BIM é uma atividade humana, portanto a preparação dos profissionais para aceitar a mudança do seu método de trabalho junto com o da empresa deve ser planejada e trabalhada para obter melhores resultados.

Conclui-se então que o planejamento do processo, a identificação do Projeto-Piloto ideal e a preparação dos profissionais da empresa são as três questões fundamentais para uma adoção produtiva e eficiente da metodologia BIM.

AGRADECIMENTOS

AGRADECEMOS A TODOS OS FUNCIONÁRIOS DA EMPRESA QUE PARTICIPARAM DAS ENTREVISTAS.

\section{REFERÊNCIAS}

CÂMARA BRASILEIRA DA INDÚSTRIA DA CONSTRUÇÃO - CBIC. Fundamentos BIM Parte 1: Implantação do BIM para construtoras e incorporadoras. Brasília, 2016 a. 120p. CDD:624.05

CÂMARA BRASILEIRA DA INDÚSTRIA DA CONSTRUÇÃO - CBIC. Implementação do BIM - Parte 2: Implantação do BIM para Construtoras e Incorporadoras. Brasília, 2016b. Disponível em: <http://sindusconbc.com.br/wpcontent/uploads/2016/10/VOLUME__2.pdf>. Acesso em: 18 de março de 2018.

EASTMAN, C. et al. Manual de BIM: Um Guia de Modelagem da Informação da Construção para Arquitetos, Engenheiros, Gerentes, Construtores e Incorporadores. Porto Alegre: Bookman, 2014. 483 p. ISBN: 978-85-8260-118-1. 
FONSECA, J. J. S. Metodologia da pesquisa científica. Fortaleza: UEC, 2002. Apostila. Disponível em: <http://www.ufrgs.br/cursopgdr/downloadsSerie/derad005.pdf>. Acesso em: 27 de março de 2018.

FREIRES, D. A. N. et al. Resistência à Mudança Organizacional: Perspectiva Valorativa e Organizacional. Revista Psico v. 45, n. 4, pp. 513-523. out.-dez. 2014. Porto Alegre. Disponível em: <https://dialnet.unirioja.es/servlet/articulo?codigo=5632996>. Acesso em: 17 de março de 2018.

KIVINIEMI, A. et al. Review of the Development and Implementation of IFC compatible BIM. Erabuild, 2008, 128 p. Disponível em: < https://www.sintef.no/globalassets/upload/byggforsk/bygninger/erabuild-bimfinal-report-january-2008.pdf>. Acesso em: 21 de março de 2018.

MANZIONE, L. Proposição de uma Estrutura Conceitual de Gestão do Processo de Projeto Colaborativo com o uso do BIM. São Paulo, 2013. Tese (Doutorado em Engenharia) - Universidade de São Paulo.

MORDUE, Stefan; SWADDLE, Paul; PHILP, David. Building Information Modeling for Dummies. 1.ed. Inglaterra, Chichester: John Wiley \& Sons, Ltd. 2016.

SACKEY, E.; TUULI, M.; DAINTY, A. BIM IMPLEMENTATION: FROM CAPABILITY MATURITY MODELS TO IMPLEMENTATION STRATEGY. Sustainable Building Conference 2013. Coventry University. Reino Unido. p 196 - 207. Disponível em: < http://www.irbnet.de/daten/iconda/CIB_DC26510.pdf>. Acesso em: 21 de março de 2018.

SUCCAR, B.; KASSEM, M. Macro-BIM adoption: Conceptual structures. Journal Automation in Construction. Teesside University. Set, 2015. Disponível em: <https://tees.openrepository.com/tees/handle/10149/593083>. Acesso em: 21 de março de 2018.

SUCCAR, B.; KASSEM, M. Building Information Modelling: Point of Adoption. CIB World Congress. Tampere, Finlândia. Junho, 2016. Disponível em: <https://www.researchgate.net/publication/301815129_Building_Information_Mod elling_Point_of_Adoption>. Acesso em: 19 de março de 2018.

YIN, R. K. Estudo de Caso: Planejamento e Métodos. 2 Ed. Brasil, Porto Alegre: Bookman, 2001. 205 p. ISBN: 85-7307-852-9. Disponível em: $<$ https://saudeglobaldotorg 1.files.wordpress.com/2014/02/yinmetodologia_da_pesquisa_estudo_de_caso_yin.pdf>. Acesso em: 18 de março de 2018. 